UNIVERSIDADE DE SÃO PAULO

FACULDADE DE ECONOMIA, ADMINISTRAÇÃO E CONTABILIDADE

DEPARTAMENTO DE ADMINISTRAÇÃO

PROGRAMA DE PÓS-GRADUAÇÃO EM ADMINISTRAÇÃO

MARKETING EXPERIENCIAL OU O USO DA EXPERIÊNCIA NO MARKETING? ESTUDO DE CASO EM HOTÉIS 5 ESTRELAS DA CIDADE DE SÃO PAULO

Marcelo Chiavone Pontes

Orientador: Prof. Dr. Marcos Cortez Campomar

SÃO PAULO 
Prof. Dr. João Grandino Rodas

Reitor da Universidade de São Paulo

Prof. Dr. Reinaldo Guerreiro

Diretor da Faculdade de Economia, Administração e Contabilidade

Prof. Dr. Adalberto Américo Fischmann

Chefe do Departamento de Administração

Prof. Dr. Lindolfo Galvão de Albuquerque

Coordenador do Programa de Pós-Graduação em Administração 
MARCELO CHIAVONE PONTES

\section{MARKETING EXPERIENCIAL OU O USO DA EXPERIÊNCIA NO MARKETING? ESTUDO DE CASO EM HOTÉIS 5 ESTRELAS DA CIDADE DE SÃO PAULO}

Tese apresentada ao Departamento de Administração da Faculdade de Economia, Administração e Contabilidade da Universidade de São Paulo como requisito para a obtenção do título de Doutor em Ciências.

Orientador: Prof. Dr. Marcos Cortez Campomar

Versão Corrigida

(versão original disponível na Faculdade de Economia, Administração e Contabilidade) 


\section{FICHA CATALOGRÁFICA}

Elaborada pela Seção de Processamento Técnico do SBD/FEA/USP

\section{Pontes, Marcelo Chiavone}

Marketing experiencial ou o uso da experiência no marketing?

estudo de caso em hotéis 5 estrelas da cidade de São Paulo / Marcelo

Chiavone Pontes. - São Paulo, 2012.

$257 \mathrm{p}$.

Tese (Doutorado) - Universidade de São Paulo, 2012.

Orientador: Marcos Cortez Campomar.

1. Marketing 2. Consumo 3. Hotéis I. Universidade de São Paulo. Faculdade de Economia, Administração e Contabilidade. II. Título.

$\mathrm{CDD}-658.8$ 
Para Nina, a minha maior e melhor experiência de amor eterno, infinito e incondicional. 


\section{AGRADECIMENTOS}

Escrever os agradecimentos é, provavelmente, um dos maiores desafios para quem conclui uma tese, porque é impossível terminar um trabalho como esse sem contar com a colaboração generosa de inúmeras pessoas.

Em primeiro lugar, agradeço a Deus, minha força, minha luz e minha esperança.

Ao Prof. Dr. Marcos Cortez Campomar que, muito mais que um Orientador, foi um Mestre, um amigo e um conselheiro em assuntos que vão muito além do marketing. Graças a ele, sei que hoje sou um profissional melhor, um Professor melhor e, certamente, um ser humano melhor.

Agradeço a todos os Professores da Fea/USP, que fizeram com que as aulas fossem prazerozas, divertidas, profundas e altamente enriquecedoras. Em especial à Prof $f^{\mathrm{a}}$. Dr ${ }^{\mathrm{a}}$. Ana Ikeda, pela confiança depositada, e pela honra do convite para as aulas na Fia. Ao Prof. Dr. Marcos Fava, que vinha de Ribeirão Preto para mostrar aos alunos o potencial do marketing no agronegócio. Ao Prof. Dr. Fauze Mattar, que desenvolveu um curso associando literatura e cinema, fazendo com que as aulas ganhasem uma dimensão inédita. Ao Prof. Dr. Edson Crescitelli, amigo e companheiro de Universidade, sempre pronto para ajudar, mostrando o universo da comunicação sob uma perspectiva bem maior. Ao Prof. Dr. Lino Rodrigues, uma das pessoas mais gentis que conheci na Usp, e que me deu uma lição que jamais esquecerei: "Pior que a ignorância, só a ilusão do conhecimento". Ao Prof. Geraldo Toledo, um dos ícones do pensamento de marketing no Brasil, que conseguia hipnotizar toda a classe com aulas sofisticadas entremeadas de fina ironia. A todos esses Professores, um muito obrigado de coração.

E, aproveitando, um muito obrigado especial à Ivanete e Bianca, que conseguem segurar todas as barras de Orientadores e Orientandos sem jamais perder o bom humor.

Agradeço também à Karina Faber e Carolina Schramm, do Hotel Grand Hyatt, à Guilherme Castro, do Hotel Hilton, e à Claudio Santos, do L'Hotel Porto Bay, pela gentileza de não apenas me receber para as entrevistas, como também por abrir as portas dos hotéis para que a pesquisa fosse mais completa e profunda. 
Agradeço aos amigos e colegas da ESPM, Escola que não somente é pioneira, como também referência na comunicação e no marketing brasileiro. A escola onde tenho a honra de dar aula há 15 anos e que, cada dia mais, deixa claro seu slogan: “Aqui é mais legal”.

Um agradecimento mais que especial à minha família, sempre unida, e que nunca deixou de me apoiar, independente do caminho que eu escolhesse. Cacá, Dedé, Cris, Gigi, Lucca e Baldan: nem preciso dizer o quanto amo vocês.

Agradeço também a todos meus queridíssimos amigos e amigas, que nem me arrisco a nomear individualmente, porque é assim que são as amizades verdadeiras - simplesmente sentimos a presença do outro, independente de tempo e espaço.

E não dá pra não agradecer a todos os meus alunos que diariamente, sem perceber, me ensinam muito mais do que aprendem, e sempre deixam claro que minha opção pela carreira acadêmica foi um enorme acerto.

Também preciso agradecer a toda comunidade da Vai-Vai, escola onde estou há 32 anos, e que todo ano me faz viver uma das maiores experiências que alguém pode sonhar.

Um muito obrigado internacional ao meu amigo, irmão, sócio e Mestre Didier Marlier, não apenas pelo apoio e incentivo, mas por me ensinar a equilibrar o Ethos, o Pathos e o Logos. Como dizemos na Vai-Vai, "tamô junto".

E, por fim, um obrigado emocionado para Cléia, uma dessas pessoas que Deus coloca em nossas vidas e todo dia me dá lições de generosidade, de carinho, de amor, de esperança. Falar o que pra você? Te amo... e não esquece que ainda faltam 11 mil dias.

A todos vocês, obrigado é muito pouco. Espero, antes de mais nada, que conseguindo terminar esta tese, eu possa honrar esse título em homenagem a cada um de vocês. E peço a Deus que ele me conceda a oportunidade de poder retribuir, ainda que só um pouco, tudo o que vocês são para mim. Um beijo enorme no coração de cada um. 
"O diabo desta vida é que, dentre cem caminhos, temos que escolher apenas um, e viver a nostalgia dos outros 99." (André Gide)

"May the presence of God be upon you And may peace be yours forever more May God's presence iluminate your heart Now and forever more" (Suphi Dance) 


\section{RESUMO}

A partir de uma análise sobre o conceito de consumo hedônico, serão estudados os conceitos de Marketing Experiencial, a partir das teorias desenvolvidas por Pine e Gilmore, e também o pensamento de Bernd Schmitt. Com base nisso, verificar-se-á que o conceito de Marketing Experiencial ainda apresenta certa confusão, e é usado em situações bastante diferentes. Comparando os autores principais, e tendo como pano de fundo uma série de estudos sobre a experiência do consumidor, conclui-se que, o que efetivamente é mais importante neste conceito é o uso que se faz das experiências sensoriais como ferramenta de marketing. Com isso, será desenvolvido um estudo de caso múltiplo onde se procura analisar o uso da experiência nos hotéis 5 estrelas da cidade de São Paulo. O resultado mostra que este é um processo que ainda está no início, mas que já apresenta algumas ações interessantes e que devem ser desenvolvidas. 


\begin{abstract}
From an analysis of the concept of hedonic consumption, we studied the concepts of Experiential Marketing, from the theories developed by Pine and Gilmore, and also the thought of Bernd Schmitt. On this basis, we find that the concept of Experiential Marketing is still very confusing, and is used in quite different situations. Comparing the principal authors, and with the backdrop of a series of studies on the consumer experience, we conclude that, effectively is more important in this concept is the use made of sensory experiences as a marketing tool. With this, we developed a multiple case study where we attempted to evaluate the use of experience in five star hotels of the city of Sao Paulo. The result shows that this is a process that is still in the beginning, but already has some interesting actions and should be developed.
\end{abstract}




\section{SUMÁRIO}

LISTA DE FIGURAS

$\begin{array}{ll}\text { LISTA DE QUADROS } & 14\end{array}$

LISTA DE TABELAS 15

LISTA DE ILUSTRAÇÕES 16

1 INTRODUÇÃO 19

1.1 Apresentação do Estudo 19

$\begin{array}{ll}1.2 \text { Objeto de estudo } & 21\end{array}$

$\begin{array}{ll}1.3 \text { Objetivos } & 21\end{array}$

1.4 Estrutura do trabalho $\quad 21$

2 REVISÃO TEÓRICA $\quad 22$

2.1 Marketing experiencial 22

2.1.1 Introdução 22

2.1.2 Holbrook \& Hirschman e a Perspectiva Experiencial 23

2.1.3 Pine II \& Gilmore e a Economia de Experiências 36

2.1.4 Bernd H. Schmitt - O Conceito de Marketing Experiencial 49

$\begin{array}{ll}\text { 2.1.5 Comentários sobre a crítica de Schmitt } & 60\end{array}$

2.1.5.1 Foco nas características funcionais e benefícios 61

2.1.5.2 Definição restrita de concorrência e categorias de produto 63

2.1.5.3 Clientes como tomadores de decisões racionais 64

2.1.5.4 Excesso de métodos analíticos, quantitativos e verbais 66

2.1.5.5 Marcas como meras identificadoras de produtos 67

2.1.5.6 Problemas do conceito de marketing 68

2.1.5.7 A satisfação do cliente $\quad 69$

2.1.5.8 Gestão do relacionamento com o cliente (CRM)

2.3 Relação entre os autores $\quad 71$

$\begin{array}{ll}\text { 2.3.1 A questão sensorial } & 76\end{array}$

$\begin{array}{ll}\text { 2.3.2 Pontos de contato } & 80\end{array}$

3 PESQUISA DE CAMPO 82

3.1 Objetivo geral do trabalho de campo 82

3.2 Metodologia do trabalho de campo $\quad 82$

$3.3 \mathrm{O}$ método estudo de caso

3.4 Escolha do setor econômico 86 
3.4.1 Turismo mundial e a realidade brasileira $\quad 87$

3.4.2 Turismo e hotelaria em São Paulo 93

$\begin{array}{ll}3.5 \text { Protocolos para a Pesquisa de Campo } & 100\end{array}$

4 ANÁLISE DO TRABALHO DE CAMPO 101

$\begin{array}{ll}\text { 4.1 Descrição do caso Grand Hyatt } & 104\end{array}$

$\begin{array}{lll}\text { 4.1.1 Fontes de Informações consultadas } & 104\end{array}$

$\begin{array}{ll}\text { 4.1.2 Informações gerais sobre o hotel } & 104\end{array}$

$\begin{array}{lll}\text { 4.1.3 Hotel Pesquisado } & 106\end{array}$

$\begin{array}{ll}\text { 4.1.4 Questões gerais de Marketing } & 108\end{array}$

$\begin{array}{ll}\text { 4.1.5 Visão sobre Marketing Experiencial } & 111\end{array}$

$\begin{array}{ll}\text { 4.1.6 Ações Sensoriais } & 115\end{array}$

4.1.7 Resumo das Ações Sensoriais 139

4.2 Descrição do caso Hilton 143

$\begin{array}{lll}\text { 4.2.1 } & \text { Fontes de Informações consultadas } & 143\end{array}$

$\begin{array}{lll}\text { 4.2.2 Informações gerais sobre o hotel } & 143\end{array}$

$\begin{array}{lll}\text { 4.2.3 Hotel Pesquisado } & 146\end{array}$

$\begin{array}{ll}\text { 4.2.4 Questões gerais de Marketing } & 148\end{array}$

4.2.5 Visão sobre Marketing Experiencial 151

4.2.6 Ações Sensoriais 154

4.2.7 Resumo das Ações Sensoriais 186

4.3 Descrição do caso L'Hotel Porto Bay 189

$\begin{array}{lll}\text { 4.3.1 Fontes de Informações consultadas } & 189\end{array}$

$\begin{array}{lll}\text { 4.3.2 Informações gerais sobre o hotel } & 189\end{array}$

$\begin{array}{lll}\text { 4.3.3 Hotel Pesquisado } & 191\end{array}$

$\begin{array}{ll}\text { 4.3.4 Questões gerais de Marketing } & 192\end{array}$

$\begin{array}{ll}\text { 4.3.5 Visão sobre Marketing Experiencial } & 198\end{array}$

4.3.6 Ações Sensoriais 201

4.3.7 Resumo das Ações Sensoriais $\quad 229$

4.4 Análises consolidadas dos casos 231

5. CONSIDERAÇÕES FINAIS 239

REFERÊNCIAS BIBLIOGRÁFICAS 242

$\begin{array}{ll}\text { APENNDICE A } & 254\end{array}$ 


\section{LISTA DE FIGURAS}

Figura 1: Contraste entre processamento de informações e visão experiencial do comportamento do consumidor

Figura 2: Progressão da oferta econômica 38

Figura 3: Tipos de Experiências $\quad 44$ 


\section{LISTA DE QUADROS}

Quadro 1: Seis fontes de evidências: pontos fortes e fracos 85

Quadro 2: Hyatt - Resumo das ações sensoriais 139

Quadro 3: Hilton - Resumo das ações sensoriais 186

Quadro 4: L'Hotel - Resumo das ações sensoriais 229

Quadro 5: Análise do uso do sentido da Visão 232

Quadro 6: Análise do uso do sentido do Olfato 233

Quadro 7: Análise do uso do sentido do Tato 234

Quadro 8: Análise do uso do sentido do Paladar 235

Quadro 9: Análise do uso do sentido da Audição 236 
LISTA DE TABELAS

Tabela 1: $\quad$ Bens hedônicos x bens utilitários 30

Tabela 2: $\quad$ Hotéis temáticos em Las Vegas $\quad 47$

Tabela 3: Evolução da chegada de turistas internacionais $\quad 88$

Tabela 4: Ranking de chegadas e receitas com turistas internacionais 89

Tabela 5: Chegada de turistas internacionais por região - 2010 89

Tabela 6: Evolução das chegadas de turistas internacionais no Brasil 91

Tabela 7: Comparativo de turistas em São Paulo 94

Tabela 8: $\quad$ Eventos em São Paulo 95

Tabela 9: Taxa de ocupação hoteleira na cidade de São Paulo em $2010 \quad 98$

Tabela 10: Classificação dos hotéis $\quad 101$

Tabela 11: Comparação dos serviços oferecidos 102

Tabela 12: Portfolio de Marcas do Hyatt Hotels Corporation 105

Tabela 13: Portfolio de Marcas do Hilton Worldwide 146

Tabela 14: Hotéis do grupo Porto Bay 190 


\section{LISTA DE ILUSTRAÇÕES}

Ilustração 1: Imagem da home page do site do Hyatt

Ilustração 2: Lounge executivo com cadeiras feitas com fibras brasileiras 115

Ilustração 3: Obra de arte de artista brasileiro exposta no lobby do hotel 116

Ilustração 4: Móveis da recepção do spa feitos com madeiras e tecidos brasileiros 116

$\begin{array}{ll}\text { Ilustração 5: Fitness Center } & 117\end{array}$

Ilustração 6: Restaurante Grand Caffé 118

\begin{tabular}{ll} 
Ilustração 7: & Business Center \\
\hline
\end{tabular}

$\begin{array}{ll}\text { Ilustração 8: } & 119\end{array}$

Ilustração 9: Fachada do Hotel $\quad 120$

Ilustração 10: Lobby do hotel $\quad 120$

Ilustração 11: Centro de convenções $\quad 121$

Ilustração 12: Piscina externa 122

Ilustração 13: Bar Upstairs Lounge 122

Ilustração 14: Quarto 123

Ilustração 15: Área externa do bar Upstairs Lounge 124

Ilustração 16: Restaurante Kinu 125

Ilustração 17: Bandeja - Restaurante Kinu $\quad 125$

Ilustração 18: Cama Hyatt $\quad 128$

Ilustração 19: Detalhe da área de banho 129

$\begin{array}{ll}\text { Ilustração 20: Box } & 130\end{array}$

Ilustração 21: Piscina indoor 131

Ilustração 22: Site restaurante Eau 132

Ilustração 23: Kit boas vindas 133

Ilustração 24: Buffet de café da manhã 134

Ilustração 25: Buffet de aperitivos do Bar Upstairs Lounge 135

Ilustração 26: Site do Bar Upstairs 136

Ilustração 27: Site do Restaurante Eau 136

Ilustração 28: Wine Library 137

Ilustração 29: Site do Restaurante Eau 142

Ilustração 30: Site - Pacote Bed \& Breakfast $\quad 153$

Ilustração 31: Site - Pacote Relaxante 153

Ilustração 32: Site - Pacote Romântico 154 
Ilustração 33: Fachada do hotel Hilton 155

Ilustração 34: Escultura do lobby vista de cima 156

Ilustração 35: Escultura do lobby - vista lateral 157

$\begin{array}{ll}\text { Ilustração 36: Piscina } & 158\end{array}$

Ilustração 37: Suíte 159

Ilustração 38: Restaurante Sol e Sombra 159

Ilustração 39: Lounge Executivo 160

Ilustração 40: Restaurante Canvas 161

Ilustração 41: Escadaria do restaurante Canvas 162

Ilustração 42: Quadro do restaurante Canvas 163

Ilustração 43: Site do restaurante Canvas 164

Ilustração 44: Cardápio do restaurante Canvas $1 \quad 165$

Ilustração 45: Cardápio do restaurante Canvas $2 \quad 166$

Ilustração 46: Prato do restaurante Canvas 166

Ilustração 47: Escultura nos corredores dos andares 168

Ilustração 48: Quadro nos corredores dos andares 168

Ilustração 49: Escultura no lobby 169

Ilustração 50: Lixeira do hall dos andares $\quad 170$

Ilustração 51: Área de trabalho dos quartos $\quad 171$

Ilustração 52: Área de descanso do quarto $\quad 172$

Ilustração 53: Toalhas de banho 174

Ilustração 54: Amenities com itens nacionais 175

Ilustração 55: Áreas de descanso e trabalho 176

Ilustração 56: Frigobar 177

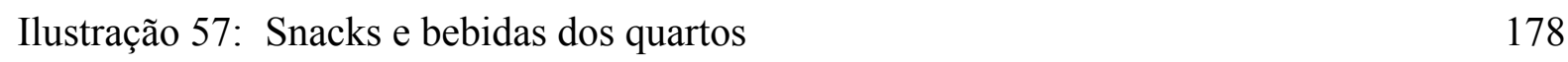

Ilustração 58: Kit chocolate $1 \quad 180$

Ilustração 59: Kit chocolate $2 \quad 180$

Ilustração 60: Kit Choco Cinno 1

Ilustração 61: Kit Choco Cinno 2 182

Ilustração 62: Hilton Chili Peppers 1

Ilustração 63: Hilton Chili Peppers 2

Ilustração 64: Adega do Restaurante Canvas 184

Ilustração 65: Site L’Hotel 199

Ilustração 66: Fachada do L’Hotel 202 
Ilustração 67: Quarto 203

Ilustração 68: Lounge 203

Ilustração 69: Recepção e concierge 204

$\begin{array}{ll}\text { Ilustração 70: Lobby } & 204\end{array}$

Ilustração 71: Hall dos andares 205

Ilustração 72: Restaurante com o quadro sobre São Paulo 206

Ilustração 73: Tapeçaria do lobby 207

Ilustração 74: Termômetro do lobby 208

Ilustração 75: Placa referente ao termômetro do lobby 208

Ilustração 76: Criado-mudo dos quartos 209

Ilustração 77: Hall do elevador $\quad 210$

Ilustração 78: Luminária e paredes do hall dos andares $\quad 211$

Ilustração 79: Centro de convenções $\quad 212$

Ilustração 80: Sala de reunião 213

$\begin{array}{ll}\text { Ilustração 81: Piscina } & 214\end{array}$

Ilustração 82: Produtos de higiene pessoal 216

$\begin{array}{ll}\text { Ilustração 83: Travesseiros e roupa de cama } & 218\end{array}$

Ilustração 84: Toalhas de banho 219

$\begin{array}{ll}\text { Ilustração 85: Roupão de banho } & 220\end{array}$

Ilustração 86: Chuveiro dos quartos $\quad 221$

Ilustração 87: Banheiras de ofurô 222

Ilustração 88: Cadeira de massagem 222

Ilustração 89: Mesa com frutas e água 223

Ilustração 90: Itens comestíveis do frigobar dos quartos 224

Ilustração 91: Bebidas do frigobar dos quartos $\quad 224$

Ilustração 92: Mesa de café da manhã 1

Ilustração 93: Mesa de café da manhã 2

Ilustração 94: Recepção com o espumante de boas-vindas 227

Ilustração 95: Bandeja de doces colocada nos quartos à noite 227

Ilustração 96: Aparelho de som dos quartos 228 


\section{INTRODUÇÃO}

\subsection{Apresentação do Estudo}

O conceito de marketing vem constantemente sendo aprimorado, desenvolvido e aprofundado, dando origem a novas abordagens, novas aplicações e novos conceitos. Um dos mais recentes conceitos na área de marketing é o chamado Marketing Experiencial que, como será visto, tem diferentes abordagens.

Estas diferentes abordagens mostram que ainda existem lacunas no conhecimento do que efetivamente vem a ser Marketing Experiencial. No campo acadêmico existem conceitos diferentes para o mesmo termo, ainda que com alguns pontos em comum.

Na prática do mercado, o conceito de Marketing Experiencial acabou por se tornar um dos temas "da moda" e, como consequência, o termo "experiência" e suas variações estão sendo cada vez mais usados na comunicação de marketing das mais diferentes empresas.

No entanto, independente da abordagem conceitual, as diferentes visões do Marketing Experiencial tem em comum o reconhecimento de que o consumidor tem um comportamento hedônico que não pode ser desprezado na comercialização de bens.

Outro ponto em comum nos conceitos de Marketing Experiencial é a importância de se estimular os 5 sentidos do ser humano, ou seja, as ações de marketing devem procurar gerar e estimular as experiências sensoriais, como meio de agregar valor e diferenciar os bens comercializados.

Evidentemente, o estímulo aos sentidos humanos deve ser feito a partir de uma certa lógica, que leve em conta as características das variáveis de marketing, seu ambiente, o comportamento do consumidor, dentre outros critérios. Como qualquer ação de marketing, as ações de marketing experiencial também devem ser pró-ativas, ou seja, devem ser feitas com base num planejamento. 
Analisar os diferentes conceitos de Marketing Experiencial, procurando entender mais profundamente suas premissas, e buscando pontos de convergência entre as diferentes abordagens é um dos objetivos desta tese.

Para consolidar os conceitos analisados, foi importante realizar uma pesquisa de campo e, para isso, foi escolhido o segmento hoteleiro.

Nas últimas décadas, o turismo vem apresentando um constante crescimento em todo o mundo. Por suas próprias características, não apenas é um setor que gera considerável receita para as localidades, como também, pelo seu caráter multifacetado, impacta inúmeros outros setores, gerando aumento de renda e emprego.

Exatamente por isso, os investimentos nos diferentes tipos de turismo, e em cada um dos seus segmentos crescem substancialmente em todo o mundo, gerando uma clara concorrência em termos globais. Como em qualquer atividade com grande concorrência, a busca por uma vantagem competitiva torna-se fundamental.

Um dos principais atores do setor turístico é o segmento hoteleiro que, assim como outros segmentos com grande competitividade, busca se diferenciar agregando valor à sua oferta.

Segundo PORTER (1991, p. 23) "a vantagem competitiva existe, quando a empresa oferece maior valor ao consumidor e consegue a preferência por seus produtos e serviços, em um nível de preços suficiente para cobrir os custos da efetivação desse valor."

Por isso, a partir dos pontos abordados acima, este trabalho analisa e questiona o conceito de Marketing Experiencial, e estuda sua utilização em hotéis 5 estrelas da cidade de São Paulo. 


\subsection{Objeto de estudo}

O tema desta tese é o marketing experiencial e sua aplicação no segmento hoteleiro.

\subsection{Objetivos}

O objetivo do estudo é identificar o uso das experiências sensoriais como ferramentas de marketing.

\subsection{Estrutura do trabalho}

A tese será formada por cinco capítulos:

a) Introdução, incluindo a apresentação do estudo, objeto, objetivos, estrutura do trabalho.

b) Revisão teórica contemplando a evolução do conceito de marketing, o conceito de marketing experiencial na visão de quatro autores, uma análise crítica a respeito destes conceitos, e a relação entre os autores.

c) Aspectos metodológicos referentes ao desenvolvimento do estudo de caso e os procedimentos para o trabalho de campo.

d) Análise do trabalho de campo, comparando a teoria com a prática.

e) Considerações finais, incluindo as limitações do estudo e as recomendações para outras pesquisas na área. 


\section{REVISÃO TEÓRICA}

\subsection{Marketing experiencial}

\subsubsection{Introdução}

O Marketing Experiencial é um conceito relativamente novo, que ainda não tem grande tradição na literatura acadêmica. No entanto, vem aumentando o número de artigos e livros que abordam o tema. Essa pouca tradição do assunto faz com que não exista um consenso sobre o seu conceito, e alguns autores que estudam esse tema apresentam visões diferentes em relação ao seu significado.

Uma das consequências disto é que o termo marketing experiencial muitas vezes é utilizado de maneira equivocada, sendo que as mais frequentes são a utilização do termo para designar outras ações de marketing, como eventos, promoções, ou ações de brand experience.

Por outro lado, parece que um dos pontos em que existe certo consenso entre os autores é no questionamento sobre os modelos de decisão de compra propostos pelos conceitos tradicionais de marketing. Estes autores, que serão vistos a seguir, criticam o fato de que os conceitos e modelos existentes não enfatizam as questões sensoriais e emocionais como elementos importantes para a decisão de compra, tratando o consumo como algo basicamente lógico, funcional e com forte aspecto racional.

Para se contrapor a estes conceitos tradicionais, os autores que estudam marketing experiencial propõe que o consumo seja entendido numa dimensão maior, enfatizando a experiência de consumo como um todo.

Há certo exagero na colocação de alguns destes autores. Talvez os conceitos mais clássicos e tradicionais de marketing não enfatizem com a profundidade desejada pelos autores de Marketing Experiencial a questão do consumo hedônico e das experiências sensoriais. Mas não é verdade que os conceitos clássicos de marketing têm uma visão restrita ao consumo mais utilitário e racional. 
Para discutir isto, serão aprofundados os conceitos teóricos sobre o tema, a partir da visão de alguns autores que se destacam por estudarem consumo hedônico e marketing experiencial: Morris B. Holbrook e Elizabeth C. Hirschman, Joseph Pine e James Gilmore, e Bernd H. Schmitt.

Também será feito um contraponto de alguns conceitos desenvolvidos pelos autores citados acima, com os conceitos clássicos desenvolvidos pelo que chamaremos aqui de "marketing tradicional".

Os conceitos referentes aos cinco autores anteriormente mencionados serão expostos ao longo desse capítulo para que, em um segundo momento, seja possível discutir as semelhanças e singularidades de suas teorias.

\subsubsection{Holbrook \& Hirschman e a Perspectiva Experiencial.}

Em 1982, Morris B. Holbrook e Elizabeth C. Hirschman publicam um artigo no Journal of Marketing intitulado "Hedonic Consumption: Emerging Concepts, Methods and Propositions". (HOLBROOK; HIRSCHMAN, 1982a).

Este trabalho pode ser colocado como um dos primeiros textos que incentiva o desenvolvimento da pesquisa sobre a perspectiva experiencial no marketing, já que os autores defendem a importância das teorias de marketing entenderem e abordarem com mais profundidade os aspectos emocionais do consumo.

Até esta época, a teoria de marketing buscava explicar os fenômenos de consumo dentro de uma visão bastante lógica e, principalmente, utilitária. Porém, esta visão era incapaz de compreender todos os fenômenos de consumo, deixando uma lacuna no entendimento do comportamento do consumidor. Holbrook e Hirschman afirmam que

"... como foi claramente reconhecido pelas pesquisas motivacionais, há certos contextos em que emoções como ódio, amor ou ciúme substituem as regras de decisão econômica dos consumidores." 
Neste artigo, os autores abordam o conceito de consumo hedônico, definindo-o como sendo os aspectos do comportamento do consumidor que se relacionam com as características sensoriais, as fantasias e os aspectos emotivos da experiência com um produto.

Ou seja, o consumo hedônico tenta entender como os elementos sensoriais, as emoções e as fantasias de um consumidor podem se manifestar em sentimentos de prazer durante o consumo.

Segundo os autores, os aspectos sensoriais não estão restritos apenas aos sentidos do consumidor (paladar, audição, olfato, tato e visão), mas incluem também as imagens mentais geradas por estes estímulos, baseadas na lembrança de experiências anteriores.

Esta visão é fundamental para que os aspectos sensoriais, como ferramentas de marketing, não sejam vistos apenas e tão somente um fim em si mesmo.

Por exemplo: ao passar por uma loja de enfeites para festas infantis, num ambiente completamente criado para o imaginário infantil, repleto de objetos chamativos de decoração e ambientes temáticos, uma criança pode ser seduzida por uma série de elementos da decoração - sensorialmente atraentes para ela -, desencadeando uma série de emoções e pensamentos que envolvem sua imaginação na possível festa de aniversário, gerando assim a sensação de prazer.

Da mesma forma, a fantasia é definida como a construção mental que o consumidor faz de imagens que ele nunca vivenciou, ou seja, as formas, as cores, as texturas, os aromas que, na verdade, nunca existiram, e são apenas criações da imaginação da pessoa.

As emoções do consumidor são os diversos sentimentos que ele pode experimentar, como diversão, prazer, raiva, medo, etc... Estes sentimentos são derivados não apenas dos estímulos sensoriais provocados pelo contato com o produto, como também da imaginação do consumidor.

Nessa perspectiva, os produtos não são vistos apenas como individualidades objetivas, mas sim como símbolos subjetivos, preocupando-se não tanto com o que o produto de fato é, mas com o que ele representa para o consumidor. 
Com isso, ainda seguindo o exemplo da loja de enfeites para festas, uma mesa temática não consiste somente no suporte material para os doces e o bolo, mas representa toda uma situação na qual a criança se imagina diante desse tema, envolvendo-a de sentimentos e sensações agradáveis.

Assim, o consumo hedônico contribui na compreensão de aspectos da perspectiva experiencial, visto que relaciona a questão dos sentidos e das emoções à origem de sensações de prazer (HOLBROOK; HIRSCHMAN, 1982a).

Ainda em 1982, os autores publicam no The Journal of Consumer Research, um artigo intitulado "The Experiential Aspects of Consumption: Consumers Fantasies, Feelings and Fun". (HOLBROOK; HIRSCHMAN, 1982b)

Este é um dos primeiros textos de marketing onde o termo "experiencial" é usado. Neste trabalho, os autores opõe o Modelo de Processamento de Informações desenvolvido por BETTMAN (1979) com a perspectiva experiencial, mostrando a importância dos aspectos experienciais no consumo.

O modelo tradicional de processamento de informações busca compreender as decisões de compra de um consumidor por meio da esquematização das etapas cognitivas que se sucedem até que um consumidor tome sua decisão final de compra.

O modelo de Bettman advoga que a tomada de decisão do consumidor é um processo de 6 (seis) etapas: identificação do problema, busca de uma solução, comparação das possíveis opções, escolha de uma das alternativas, realização da compra e reavaliação da sua decisão de compra.

Um modelo bastante parecido aparece em KOTLER e KELLER (2006). Os autores citam diferentes estudos para sintetizar e apresentar um processo de decisão de compra chamado de "Modelo de Cinco Estágios".

Segundo esse modelo, o consumidor identifica o problema, busca informações, compara as possíveis opções, toma a decisão de compra, e reavalia sua decisão. 
Pode-se concluir que os dois modelos são praticamente iguais, apenas com a diferença de que, no primeiro, os autores separam a escolha das alternativas com a tomada de decisão em dois momentos diferentes, enquanto que no modelo apresentado por Kotler e Keller, estas duas atitudes são colocadas como uma etapa apenas.

De qualquer maneira, como citado acima, o modelo de Bettman tem um foco bastante utilitário, na visão de Holbrook e Hirschman. Para estes autores, o problema deste modelo é que ele não leva em conta fenômenos importantes do consumo, na medida em que entende que as escolhas dos consumidores são feitas com base em decisões lógicas. Assim, os consumidores são vistos como pensadores racionais que solucionam problemas de maneira sistemática para tomar suas decisões de compra.

Os autores criticam o Modelo de Processamento de Informações por este ignorar questões como atividades de lazer lúdico, prazeres sensoriais, devaneios, satisfação estética e reações emocionais.

Exemplificando a crítica na aplicação desse modelo: supondo que o consumidor demonstre intenção de comprar um shampoo. Segundo esse modelo, o consumidor primeiramente identifica o problema (ausência de shampoo), busca uma solução (procura informações sobre diferentes shampoos), compara as possíveis opções (compara os atributos das marcas com suas preferências de forma a maximizar os benefícios de sua escolha), escolhe uma das alternativas (tendo como base as informações e análises feitas, buscando otimizar a relação custo $\mathrm{x}$ benefício), realiza a compra (adquire o produto com características e benefícios relevantes) e reavalia sua decisão de compra (compara a performance do shampoo com suas expectativas iniciais).

Apesar de determinados produtos serem comprados dessa maneira, Holbrook e Hirschman criticam o excesso de objetividade e racionalidade desse modelo, e propõem outra perspectiva que considera aspectos mais subjetivos nas decisões dos consumidores: a perspectiva experiencial:

A perspectiva experiencial explora os significados simbólicos de características mais subjetivas (alegria, sociabilidade, elegância). (HOLBROOK; HIRSCHMAN, 1982b - p. 134) 
$\mathrm{Ou}$ seja, além de abranger os benefícios funcionais de um produto, essa perspectiva compreende também os significados simbólicos do consumo, ou seja, o que o evento significa para o consumidor dentro de uma visão mais ampla.

Os autores defendem que as decisões do consumidor são inerentes a cada indivíduo, ou seja, cada consumidor tem seus próprios critérios e motivações para a tomada de decisões, levando em conta não apenas os aspectos materiais da oferta, mas também considerando características que satisfaçam seus desejos emocionais.

Exemplificando este conceito: ao entrar numa loja de artigos esportivos, um consumidor pode ver uma determinada chuteira que o faça lembrar-se de eventos prazerosos em que aquela chuteira ou marca estava presente, como um campeonato de futebol no clube onde o próprio consumidor foi um dos vencedores.

A crítica que os autores fazem ao modelo de processamento de informações é que este não permite uma compreensão precisa para situações de consumo como o apresentado.

Isso acontece porque, segundo os autores, a visão utilitária do Modelo de Processamento de Informações não leva em conta os aspectos subjetivos e emocionais do consumo, como se procurou demonstrar no exemplo da chuteira.

Além disso, a perspectiva experiencial é fenomenológica, ou seja, ela compreende e interpreta os fenômenos apresentados à percepção do consumidor por meio dos sentidos. Para isso, esta visão experiencial entende o consumo como algo essencialmente subjetivo, com inúmeros significados simbólicos, respostas hedônicas e critérios estéticos.

"O consumo começou a ser visto envolvendo um fluxo constante de fantasias, sentimentos e diversão..." (HOLBROOK; HIRSCHMAN, 1982b, p. 132)

Ora, sendo a essência do consumo algo subjetivo, seu significado e sua importância acabam variando de pessoa para pessoa, que reagem de maneiras diferentes a determinados estímulos internos e externos. Assim, o consumo representa uma constante transformação do estado emocional para o consumidor. 
No entanto, é fundamental destacar que nem todos os produtos são consumidos de maneira subjetiva, assim como nem todos provocam esse tipo de fluxo emocional. São inúmeras as compras que são feitas de maneira habitual, rotineira, quase automática. É difícil imaginar a compra de sal ou detergente como algo subjetivo, recheado de fantasias, diversões ou sentimentos.

Da mesma maneira, parece certo exagero imaginar que a decisão de compra de um plano de previdência privada ou de um novo conjunto de amortecedores para um carro seja feito com base apenas em fantasias e motivações emocionais, sem se levar em conta as características objetivas do plano de previdência, como coberturas, taxas, duração e outros. O mesmo acontece com os amortecedores, que devem ter características técnicas que se adequam ao modelo do carro.

Num primeiro instante, analisando a crítica que Holbrok e Hirschman fazem aos modelos tradicionais de tomada de decisão, fica claro que os autores radicalizaram nos argumentos.

Em primeiro lugar, porque os modelos tradicionais não desprezam totalmente as questões subjetivas do consumo. KOTLER e KELLER (2006) deixam isso claro ao mostrar que o comportamento do consumidor é fortemente influenciado não apenas pelos estímulos de marketing, como também pelos estímulos ambientais. Além disso, o consumidor é influenciado por fatores sociais, culturais, pessoais e psicológicos.

Ou seja, se as questões como divertimento, fantasia e sentimentos não são expostos de maneira clara, também é verdade que as questões não tão objetivas, como as citadas acima, são colocadas de maneira bastante explícita.

Por outro lado, esses modelos servem para explicar o comportamento de compra de vários produtos, que vão das compras industriais - o B2B - até produtos em que o envolvimento do consumidor é maior.

Em outras palavras - a perspectiva experiencial, colocada como um modelo de tomada de decisão que corrige a objetividade e a racionalidade dos modelos tradicionais de processamento de informações acabou mostrando que, se por um lado, de fato corrige 
algumas das falhas destes modelos tradicionais, por outro lado, não leva em conta as questões mais lógicas e racionais presentes nas ocasiões de consumo de determinados bens.

Com isso, após compararem ambas as perspectivas ao longo do artigo, HOLBROOK e HIRSCHMAN (1982a) concluem que abandonar a abordagem de processamento de informações é inconveniente, sendo mais frutífero complementar e enriquecer essa abordagem com a perspectiva experiencial.

Isso se deve à insuficiência do modelo de processamento de informações em explicar determinados fenômenos de consumo, como compras habituais ou compras que exijam comparações e objetividade. Dessa forma, a perspectiva experiencial contribui na compreensão do significado de fenômenos mais subjetivos e que abranjam maior envolvimento emocional.

De maneira resumida e simplificada, podemos dizer que esta visão dicotômica entre razão e emoção para explicar os fenômenos de consumo geram interpretações incompletas, pois o consumidor não pode ser entendido a partir de um único ponto de vista.

Conclui-se que o modelo de processamento das informações é mais adequado quando são analisados bens utilitários, enquanto a perspectiva experiencial acaba por ser mais aplicada para a compreensão do consumo de bens hedônicos.

Esta distinção entre bens hedônicos e utilitários também foi objeto de pesquisa de CLEMENT et al (2006), que afirma que esses bens podem ser diferenciados em duas dimensões, conforme vemos na Tabela 1: 
Tabela 1. Bens hedônicos $\mathrm{x}$ bens utilitários

\begin{tabular}{|c|c|c|}
\hline Variáveis & Bens Hedônicos & Bens Utilitários \\
\hline \multicolumn{3}{|l|}{ Parâmetro de Produto } \\
\hline Tipo de bem & Experiência & Procura \\
\hline Incerteza da qualidade & Relativamente alto & Relativamente baixo \\
\hline Atributos & $\begin{array}{l}\text { Subjetivo, } \\
\text { simbólico/estético, } \\
\text { intangível, escasso, } \\
\text { sazonal }\end{array}$ & $\begin{array}{l}\text { Objetivo, } \\
\text { funcional/qualitativo, } \\
\text { tangível, geralmente } \\
\text { produtos de massa }\end{array}$ \\
\hline Sazonalidade & Dependente & Independente \\
\hline Diversidade & Único & $\begin{array}{l}\text { Múltiplas versões de um } \\
\text { produto }\end{array}$ \\
\hline Ciclo de Vida & $\begin{array}{l}\text { Rápido declínio, } \\
\text { curto espaço de tempo }\end{array}$ & $\begin{array}{l}\text { Curva em forma de sino; } \\
\text { prazo de vendas depende } \\
\text { do produto }\end{array}$ \\
\hline \multicolumn{3}{|c|}{ Parâmetros de Demanda } \\
\hline Risco de consumo & $\begin{array}{l}\text { Relativamente alto } \\
\text { (risco econômico e social) }\end{array}$ & $\begin{array}{l}\text { Relativamente baixo } \\
\text { (risco econômico e técnico) }\end{array}$ \\
\hline Experiência de consumo & Multisensorial e variável & $\begin{array}{l}\text { Não multisensorial e } \\
\text { constante }\end{array}$ \\
\hline Envolvimento & $\begin{array}{l}\text { Baixo envolvimento } \\
\text { cognitivo, alto } \\
\text { envolvimento emocional }\end{array}$ & $\begin{array}{l}\text { Alto envolvimento } \\
\text { cognitivo, baixo } \\
\text { envolvimento emocional }\end{array}$ \\
\hline Avaliação do produto & Emocional, subjetivo & $\begin{array}{l}\text { Racional, analítico, } \\
\text { objetivo }\end{array}$ \\
\hline Motivos de compra & $\begin{array}{l}\text { Emocional, busca de } \\
\text { variedade, expressão da } \\
\text { individualidade e da } \\
\text { subjetividade, } \\
\text { caráter simbólico }\end{array}$ & $\begin{array}{l}\text { Racional, funcionalidade } \\
\text { prática, utilidade na } \\
\text { solução de problemas, } \\
\text { qualidade }\end{array}$ \\
\hline Decisão de compra & $\begin{array}{l}\text { Escolha holística (depende } \\
\text { das características } \\
\text { subjetivas do produto) }\end{array}$ & $\begin{array}{l}\text { Escolha racional e } \\
\text { cognitiva (depende } \\
\text { das características objetivas } \\
\text { do produto) }\end{array}$ \\
\hline Tipo de compra & Impulso & Conveniência \\
\hline Frequência de consumo & Limitada & Depende do produto \\
\hline
\end{tabular}

Fonte: CLEMENT et al, 2006, p. 157 
Analisando a tabela anterior, entende-se que esta divisão é adequada para uma compreensão maior entre as diferenças dos bens hedônicos e utilitários sob o ponto de vista mais conceitual e genérico. Evidentemente que os produtos e serviços não podem ser divididos apenas em duas categorias.

A conclusão de Holbrook e Hirschman parece ser a mais adequada, pois propõe que os fenômenos de consumo sejam estudados com uma abordagem mais ampla.

Esta é a mesma conclusão de BATRA e AHTOLA (1990), que afirmam:

“a perspectiva hedônica e utilitária como motivação para o consumo não precisa ser (e geralmente não são) mutuamente exclusivas: um creme dental pode tanto prevenir as cáries e proporcionar prazer a partir do seu gosto. As motivações também não precisam ser consistentes, pois um produto que dá prazer agora pode, na verdade, ser ruim para numa perspectiva mais utilitária (por exemplo, tabagismo), enquanto outro bem que não dá nenhum prazer, pode de fato ser bastante valioso (por exemplo, ir ao dentista)".

$\mathrm{Ou}$ seja, o consumo deve ser entendido a partir de perspectiva bidimensional e não excludentes, como acontece quando a perspectiva é unicamente utilitária ou hedônica.

Sobre isso, BATRA e ATHOLA (1990) concluem:

“As atitudes dos consumidores são bidimensionais, porque os consumidores compram bens e serviços por duas razões básicas: (1) para consumação de uma gratificação afetiva (hedonista, a partir de atributos sensoriais), e (2) por razões instrumentais, utilitárias, quando está mais preocupado com "expectativas de conseqüencias" de uma variedade de meios e fins, a partir de atributos funcionais”.

Neste trabalho, BATRA e ATHOLA (1990) mostram que o hedonismo e o utilitarismo não são duas extremidades de uma escala unidimensional - ao contrário, os produtos variam em seu nível de percepção dos atributos hedônicos e utilitários. 
Este mesmo ponto é discutido por BABIN et al (1994) que afirmam que uma experiência de compra pode ser valiosa ou não em mais de uma maneira. Por isso, "é importante a visão conjunta da perspectiva utilitária e hedônica que, além de tudo, podem fornecer insight sobre vários comportamentos de compra incluindo a compra por impulso e as compras compulsivas, por exemplo, que são difíceis de explicar usando-se apenas as explicações funcionais”.

Nota-se que a ideia de uma visão bidimensional, que leve em conta os aspectos utilitários e hedônicos do consumo gerou, dentre outras coisas, uma preocupação em se desenvolver escalas que possam avaliar a percepção dos consumidores nas duas dimensões.

Além dos dois trabalhos mostrados anteriormente, de BATRA e ATHOLA (1990), e de BABIN et al (1994), pode-se citar também SPANGENBERG (1997) para quem essas escalas podem "trazer benefícios para os anunciantes, que entendendo se um mercado-alvo visa essencialmente benefícios hedônicos ou utilitários, poderia direcionar melhor seus recursos, por exemplo, sabendo se os diferentes tipos de consumidores são mais ou menos sensíveis a diferentes métodos de promoção de vendas”.

O estudo de VOSS et al (2003) também trabalha a questão de diferenças existentes entre consumo hedônico e utilitário não apenas nas ações de promoção de vendas, como também nas possibilidades de precificação. Segundo o autor, "marcas que são muito valorizadas na dimensão hedônica são mais capazes de cobrar um preço premium ou se envolver em promoções de vendas".

Um exemplo de utilização de ambas as perspectivas pode ser dado ao se analisar a compra de um carro, pois pode ser considerado não apenas como os consumidores percebem aspectos funcionais, como o desempenho do motor ou qualidade de seus componentes, mas também levar em conta os aspectos subjetivos, como a escolha da cor do carro ou o status que o carro proporciona ao comprador.

A figura 1, a seguir, é utilizada pelos autores para comparar a perspectiva experiencial com o modelo de processamento de informações. 


\section{Figura 1 - Contraste entre processamento de informações e visão experiencial do comportamento do consumidor}

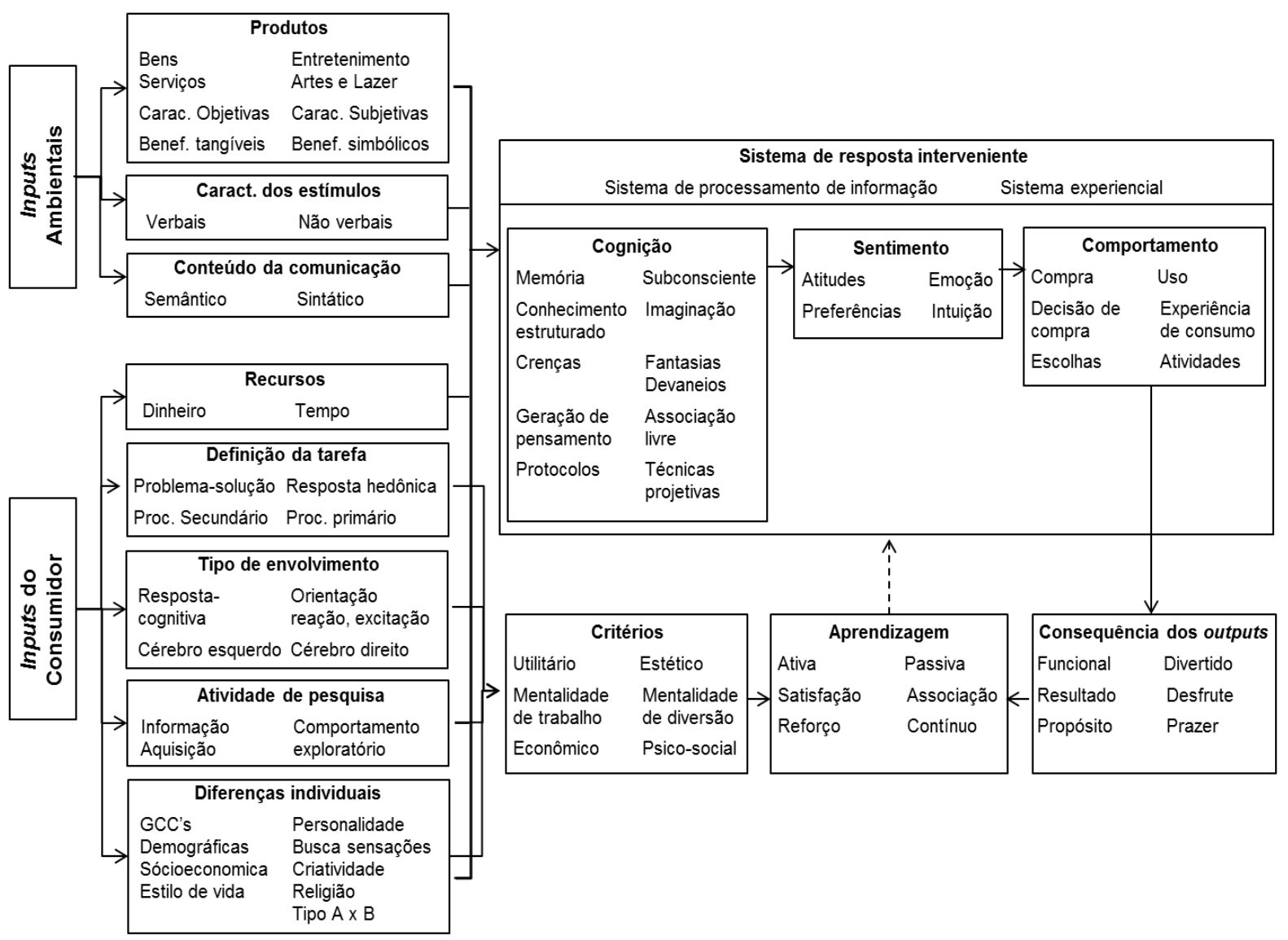

Nota: Os dados à esquerda dos quadros referem-se ao processamento de informações, e os dados à direita à perspectiva experiencial.

Fonte: HOLBROK e HIRSCHMAN, 1982b

Como pode ser visto ver na figura acima, o modelo relaciona os inputs do ambiente e os inputs do consumidor com o ciclo formado pelo sistema de intervenção de respostas do consumidor, consequências resultantes da compra (ou experiência) e a aprendizagem proveniente do processo.

Os inputs são fenômenos originários do ambiente ou de características internas do consumidor que impactam nos critérios de compra de um cliente ou no sistema de intervenção de resposta do consumidor ao longo do processo de decisão de compra.

Nos inputs do consumidor, o modelo confronta como as duas perspectivas (experiencial e de processamento de informações) analisam as diferenças individuais entre consumidores, os 
recursos utilizados na compra, o tipo de envolvimento entre a pessoa e a situação de compra, a definição da tarefa a se buscar na compra e, por fim, o tipo de pesquisa a ser utilizado para entender o processo de compra.

Os inputs do ambiente abrangem o produto ofertado, o conteúdo da comunicação e a propriedade dos estímulos. Os dois tipos de inputs ocasionam alterações no psicológico do indivíduo, afetando diretamente sua percepção quanto aos eventos proporcionados.

Explicando melhor: caso uma pessoa entre em uma loja de conveniência, a exposição dos produtos, as ações de comunicação presentes na loja, a forma como ele é atendido (inputs do ambiente) ou a motivação de sua compra, a forma como realizará o pagamento (inputs do consumidor) são variáveis que afetam seu consciente e inconsciente, gerando mudanças de comportamento, mudanças emocionais ou até mesmo mudanças em suas expectativas, além do critério quanto à ocasião de compra.

Em seguida, esses inputs são interpretados conforme o sistema de intervenções de respostas da pessoa, composto por aspectos cognitivos, emocionais e comportamentais.

Esse sistema representa o conjunto de reações psicológicas (em nível cognitivo, emocional e comportamental) ativadas no momento em que uma pessoa entra em contato com algum input (próprio ou do ambiente), gerando uma mudança de sua percepção quanto à ocasião de compra.

Exemplificando cada uma das três reações: um consumidor que consuma um alimento estragado ou com prazo de validade vencido pode reagir de diferentes formas.

Ele pode se questionar quanto à qualidade de outros produtos da mesma marca (reação cognitiva), pode se sentir enganado, frustrado ou aborrecido (reação emocional) e/ou decidir não mais comprar dessa marca específica, ou ainda, decidir consumir o produto com antecedência, verificando previamente sua qualidade (reação comportamental).

A aprendizagem, ou seja, a forma na qual o consumidor (re)avalia o impacto dos inputs no resultado final da aquisição, é compreendida de forma distinta pelas diferentes perspectivas. 
No modelo de processamento de informações, o processo de aprendizagem se dá de forma consideravelmente direta, quase impositiva.

De forma distinta, a perspectiva experiencial tende para um viés mais flexível, visto que considera a aprendizagem como sendo algo mais reativo, ou seja, propõe que esse processo resulte da interação reativa entre ambas as partes - consumidor e organização -, não sendo assim algo unilateral.

Há de se considerar também que a motivação da compra para o consumidor é entendida de forma distinta para ambas as perspectivas. As consequências dos outputs - resultado da compra ou experiência - correspondem a como o consumidor reagiu aos estímulos internos e externos de forma a reformular seu sistema de resposta, impactando em sua percepção e, consequentemente, no processo de aprendizagem, que guiará esse consumidor em próximas ocasiões.

Enquanto o modelo de processamento de informações foca na função, no resultado ou no propósito do consumo, a perspectiva experiencial prioriza a satisfação dos prazeres e desejos do consumidor. (HOLBROOK; HIRSCHMAN, 1982b)

A partir dos dois trabalhos iniciais de Holbrook e Hirschman, além dos autores já citados (BATRA e AHTOLA, 1990; BABIN, 1994; SPANGENBERG et al.,1997; VOSS, et al., 2003), uma série de outros trabalhos acadêmicos foram desenvolvidos para uma melhor compreensão do consumo hedônico e utilitário. É o caso do trabalho de LEONARD (2005), que discute a questão do consumo de fantasias pelos consumidores.

NELSON e MEYVIS (2008) também estudam as experiências hedônicas, num interessante estudo que mostra que a interrupção de uma experiência de consumo pode fazer com que as experiências agradáveis sejam ainda mais agradáveis e, do mesmo modo, as experiências desagradáveis, quando interrompidas, tendem a ser ainda mais desagradáveis.

Outro trabalho interessante sobre o tema foi desenvolvido por CHAN e MUKHOPADHYAY (2010), que procura analisar como a avaliação do consumo de produtos hedônicos varia com a passagem do tempo entre a escolha do produto e seu consumo, incluindo outra variável, que diz respeito à decisão de compra ser do consumidor ou de outra pessoa. 
OKADA (2005) mostra as pessoas querem se divertir, mas que o divertimento levanta questões como o sentimento de culpa e a necessidade de justificativa. Com base nisto, a autora desenvolveu uma pesquisa em que examina que o consumo hedonista versus o consumo utilitário pode variar dependendo do contexto da decisão de compra.

Todos estes trabalhos reforçam a ideia de que a abordagem que leva em conta as duas perspectivas é a mais completa para uma melhor compreensão dos fenômenos de consumo.

\subsubsection{Pine II \& Gilmore e a Economia de Experiências.}

Em julho de 1998, B. JOSEPH PINE II e JAMES H. GILMORE abordaram o conceito de experiência do consumidor em seu artigo "Welcome to the experience economy" para a Harvard Business Review.

Como será visto, o conceito defendido por estes autores diverge um pouco do caminho seguido por Holbrook e Hirschman. Para Pine II e Gilmore, as experiências representam um tipo de produção econômica que carece de maior organização, pois os consumidores, os economistas e, enfim, o mercado como um todo coloca equivocadamente esta produção econômica no setor de serviços.

Os autores defendem que as experiências ocorrem "sempre que uma empresa usa intencionalmente serviços como cenário e bens como acessórios para envolver a pessoa". (PINE II; GILMORE, 1999 - p. 23)

Segundo os autores, "quando uma pessoa paga por um serviço, ela está adquirindo um conjunto de atividades intangíveis executadas em seu interesse. Mas quando ela adquire uma experiência, está pagando para dedicar seu tempo a desfrutar de uma série de eventos memoráveis que uma empresa encena - como em uma peça de teatro - para envolvê-la de modo pessoal" (PINE II; GILMORE, 1999 - p. 12.)

As experiências ocorrem no interior de qualquer indivíduo que tenha sido engajado em um nível físico, emocional, intelectual e até mesmo espiritual, ou seja, são inerentes à pessoa. Isto significa que duas pessoas não conseguem ter a mesma experiência. 
Como cada pessoa apresenta percepções diferentes das demais, os indivíduos não conseguem passar pelas mesmas experiências, visto que essas experiências afetam os sentidos e sentimentos dos consumidores de formas distintas. Caso duas pessoas assistam a um concerto musical, mesmo que permaneçam juntas ao longo de toda a experiência, apresentarão percepções, sentimentos e julgamentos únicos.

SHAW (2002) defende a mesma ideia de que as experiências são percebidas de formas diferentes pelos consumidores, ou seja, nenhuma é vivenciada da mesma maneira por duas pessoas.

Dessa forma, quando um consumidor ingressa em uma experiência, além das variáveis externas, uma série de características próprias desse consumidor, como suas emoções ou expectativas, impactam em sua percepção, fazendo com que cada experiência derive da interação entre o evento encenado e o estado de ser e de espírito do indivíduo. (PINE II; GILMORE, 1999)

Pine II e Gilmore deixam bem claro que as experiências devem ser planejadas, ou seja, os negócios da economia da experiência são pró-ativos em relação à proposta de fazer o consumidor vivenciar sensações diferentes. Para isso, os autores fazem diversas comparações entre as empresas do setor experiencial e o mundo do teatro, muitas vezes usando a própria terminologia do universo artístico.

Por exemplo, o negócio é visto como um "palco", os funcionários desempenham papéis como “atores", seguindo "scripts". As sensações são provocadas a partir de "enredos", e os clientes devem ser tratados como "plateia".

A figura 2 ilustra as diferenças existentes entre as diversas ofertas econômicas a partir da sua posição competitiva e preço: 
Figura 2: Progressão da oferta econômica

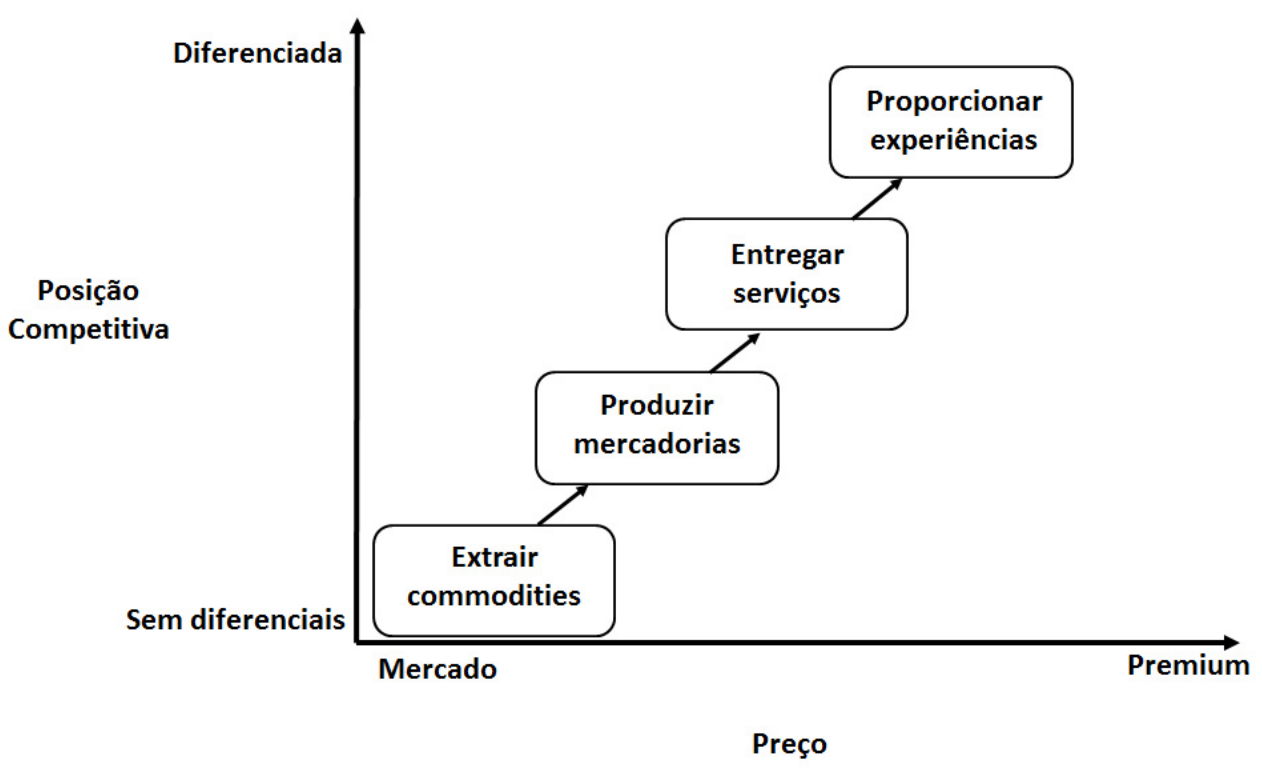

Fonte: Adaptado de PINE II e GILMORE, 1999, p. 34

De acordo com o quadro, os autores mostram que, quanto mais diferenciada é a posição competitiva, maior a possibilidade de cobrança de "premium prices". Para isso, analisam as diferentes ofertas econômicas:

a) Commodities: As economias agrárias se caracterizam pela extração de ofertas com base nos recursos naturais, como é o caso das atividades de caça, pesca, plantio, mineração, ou qualquer outra forma de extração natural. Por se tratarem de ofertas extremamente semelhantes - com ausência ou baixíssima diferenciação - seu valor reside quase que unicamente no preço cobrado por ela.

As commodities se caracterizam por serem ofertas fungíveis, ou seja, não possuem exclusividade própria. Dessa forma, por não se distinguirem entre si, as commodities são facilmente substituíveis, pois não apresentam distinção suficiente para impedir que uma unidade seja reposta por outra.

Por exemplo: um ourives que queira comprar cem gramas de ouro para a fabricação de uma joia, independentemente do fornecedor, busca o menor preço possível, visto que essa oferta possui qualidades idênticas, não havendo diferenciação suficiente para distinguir a proposta dos fornecedores senão pelo preço. 
O mesmo raciocínio é valido para outras commodities, o que faz com que a demanda por este tipo de oferta econômica dependa fundamentalmente de como as características materiais inerentes à oferta interessam ao mercado.

Dentro deste setor, os comerciantes tem, basicamente, a função de vender o que foi extraído da natureza, não distinguindo os consumidores que compõe o mercado, já que, independentemente de quem comprar as commodities, as características dessas ofertas serão as mesmas.

Ainda hoje são encontradas inúmeras organizações com esta visão, ou seja, oferecem produtos sem nenhum valor agregado, apostando apenas na variável preço para conseguir fechar seus negócios.

b) Produtos: Saindo do segmento de commodities, o próximo tipo de economia encontra-se num estágio um pouco mais diversificado em relação ao gênero da oferta. Estas são as economias industriais, caracterizadas pela produção de bens e mercadorias na forma de um "produto". Os produtos são itens tangíveis, compostos por matérias primas e que, diferentemente das commodities, podem ser diferenciados, o que implica na não dependência singular no preço da oferta.

Além disso, a demanda por produtos se baseia na preferência por atributos, que são qualidades associadas à oferta. Assim, compradores de sabonetes, por exemplo, podem estar interessados em diferentes atributos: perfume, hidratação, poder bactericida, etc.

Os autores afirmam que dentro das economias industriais, os produtos apresentam a padronização como atributo chave. Isso se deve ao fato dos fabricantes produzirem para grandes quantidades de usuários anônimos, ou seja, como os fabricantes não sabem a quem se destinam seus produtos, devem padronizar suas ofertas de modo a satisfazer uma quantidade considerável de compradores que busquem os atributos semelhantes.

Esta visão parece ser muito radical. Talvez tenha sido verdade em algum momento, mas a produção em massa vem sendo questionada há muito tempo pelos autores de marketing e negócios. 
Após a Segunda Guerra Mundial, as condições de mercado sofreram profundas modificações. O desenvolvimento tecnológico, o aumento da concorrência empresarial, a globalização e o crescimento da economia provocaram mudanças nas relações de troca.

Os desejos e necessidades dos consumidores não necessariamente são os mesmos, pois cada indivíduo é diferente de outro. Assim, para satisfazer de maneira mais completa seus desejos, as empresas têm que aumentar o número de opções de cada produto (tamanho, sabor, design, marca, preço, etc...), procurando se ajustar às características da demanda.

Como é mostrado por SCHWARTZ (in TOFLER, 1970), "de uma unidade homogênea única, o mercado de massa explodiu em uma série de mercados segmentados, fragmentados, cada qual com as suas próprias necessidades, gostos, modos de vida”.

Tais mudanças reforçaram a pressão para que as empresas iniciassem um processo de desmassificação da sua linha de produtos. No seu clássico artigo "Miopia em Marketing", Levitt chega a afirmar que "a melhor maneira de uma firma ter sorte é construí-la por si mesma. Isso exige o conhecimento daquilo que faz um negócio ter êxito. E um dos maiores inimigos deste conhecimento é a produção em massa”.

Toffler, já nos anos 70, afirmava que "a sociedade do futuro oferecerá não um fluxo restrito e padronizado de bens, mas a maior variedade de bens e serviços não-padronizados que qualquer sociedade jamais viu. Estamos caminhando não para mais uma extensão da padronização material, mas em direção à sua negação dialética.” (1970)

O próprio Toffler, anos depois, reafirmava esta posição, mostrando que "no passado, a companhia que sabia como padronizar mais eficazmente era capaz de superar suas concorrentes. No futuro, a companhia que souber como despadronizar eficazmente pode se tornar a vitoriosa." (1985)

KOTLER e KELLER (2006) afirmam que o "mercado não é mais o que era antes". Eles mostram várias mudanças que estão acontecendo nos mercados e nas empresas, e uma das mudanças apontadas é a Customização, ou seja, a tendência dos consumidores cada dia mais desejarem produtos personalizados ou, pelo menos, produtos que possam receber um toque mais pessoal. 
POPCORN e MARIGOLD (1997) chamam isso de "Egonomia", afirmando que esta "é uma das formas mais eficazes de se chegar aos consumidores, pois apela para sua individualidade".

Fica evidente que a visão da economia de produto podia até pensar unicamente em produção em massa mas, nos dias de hoje, é fundamental que as empresas desenvolvam um portifólio de produtos com características que vão além da massificação, procurando ao menos respeitar e, claro, atender as características de segmentos de consumidores.

c) Serviços: No estágio seguinte à economia industrial, surge a economia dos serviços, que são definidos pelos autores como sendo "atividades intangíveis personalizadas para atender ao pedido individual de clientes conhecidos". (PINE II; GILMORE, 1999 - p. 19)

Como podemos ver, esta definição de serviços difere um pouco de definições clássicas, como a de (KOTLER; KELLER, 2006, p. 397), para quem “o serviço é qualquer ato ou desempenho, essencialmente intangível, que uma parte pode oferecer a outra e que não resulta na propriedade de nada. A execução de um serviço pode estar ou não ligada a um produto concreto".

Uma distinção importante entre produtos e serviços é o fato de os serviços serem entregues sob demanda de clientes específicos - e não produzidos para um usuário anônimo. Assim, como os serviços atendem à tarefas particulares, os atributos chave da oferta sofrem uma transformação em sua natureza, passando de uma oferta padronizada (como é o caso do produto) para uma oferta customizada (visto que cada cliente recebe um conjunto de benefícios "sob medida").

Esta afirmação também parece um pouco radical, pois nem todos os serviços ofertados são customizados - passagens de ônibus, serviços públicos de maneira geral, cursinhos prévestibulares, etc...

Os autores também mostram que, por abranger aspectos tangíveis e intangíveis, os clientes percebem maior valor nos serviços, do que em produtos e commodities. Seguindo esse raciocínio, os fabricantes de produtos, fugindo da commoditização de suas ofertas, buscam entregar serviços atrelados a sua oferta central (produto) como forma de aumentar o valor percebido pelos usuários. 
d) Experiências: Diferentemente da economia de serviços - onde a oferta é fundamentada em torno de conjunto de elementos intangíveis - a natureza da oferta da economia de experiências se baseia na memorabilidade dos eventos proporcionados ao longo da experiência ofertada.

Como dito anteriormente, uma pessoa que compra uma experiência paga para passar seu tempo desfrutando de uma série de eventos que uma empresa apresenta de forma pessoal e memorável. Como o tempo passa a ser uma variável determinante na oferta das experiências, estas não são entregues sob demanda, como os serviços - ao contrário, as experiências são reveladas ao longo do tempo.

Por fim, as experiências se distinguem da oferta de serviços pois os fatores de demanda deixam de focalizar somente os benefícios aos clientes, para enfatizar as sensações invocadas (PINE II; GILMORE, 1999).

Pine II e Gilmore defendem que a experiência não é a última das ofertas econômicas. Na medida em que um número maior de empresas começa a proporcionar experiências, essa oferta passa a se tornar commoditizada, forçando as empresas a buscarem meios de diferenciarem suas experiências.

Para isso, os autores sugerem às organizações que encenem não somente um evento isolado, mas proporcionem uma série de experiências, possibilitando, assim, alcançar um efeito mais duradouro no comprador. Pine II e Gilmore denominam essa nova oferta como sendo "transformações".

As transformações ocorrem sempre que "uma experiência é customizada exatamente para suprir as necessidades individuais do consumidor" (PINE II; GILMORE, 1999, p. 196), para que ele alcance um fim ou propósito específico, mudando seu estado de ser. Ou seja, as organizações customizam as experiências com o intuito de alcançar um efeito mais profundo e duradouro no consumidor. 
Para isso, as organizações devem guiar os consumidores em uma série de eventos relevantes para que, junto à empresa, esses consumidores alcancem determinado objetivo ou desejo que apresentem relevância e significado para eles. Um exemplo de transformação se dá quando uma pessoa procura uma empresa que disponibilize suplementos alimentares para uma alimentação mais saudável.

De acordo com os autores, caso essa empresa buscasse guiar uma transformação junto ao consumidor, ela não se preocuparia somente em disponibilizar suplementos alimentares de qualidade, mas tentaria proporcionar uma melhor qualidade de vida para o consumidor, por meio do acompanhamento de seu bem-estar físico. Para isso, realizaria exames regulares para examinar os avanços na condição física e alimentar de seu cliente, informando-lhe de opções e procedimentos que o ajudassem a alcançar seu objetivo de uma vida mais saudável (PINE II e GILMORE 1999).

Segundo os autores, uma experiência pode envolver um consumidor em diferentes dimensões, ou seja, partes componentes das experiências. Pine e Gilmore consideram duas das mais importantes dimensões como sendo a participação do cliente na experiência e a conexão entre o ambiente e o consumidor.

Em relação à participação do cliente, o indivíduo pode apresentar uma participação ativa ou passiva, dependendo de como ele afeta pessoalmente a performance ou evento derivado da experiência.

É possível observar esse tipo de dimensão em diferentes ocasiões de um espetáculo de circo. Há momentos em que o espectador apenas observa a ação no picadeiro, sem que se envolva com ela. Entretanto, há outros em que ele é convidado para participar dessa ação - junto à encenação dos palhaços, por exemplo, influenciando pessoalmente na experiência proporcionada pelo circo.

A conexão entre o consumidor e o ambiente descreve o tipo de vínculo ou ligação que unirá o consumidor ao evento ou performance. Essa relação pode ocorrer na forma de uma imersão ou absorção - que varia de acordo com a atenção da pessoa ao evento - envolvendo o consumidor em um nível físico de participação ou somente mental. 
Em outras palavras, quando as relações se dão na forma de uma imersão, o consumidor adentra a experiência de modo a sentir-se parte dela, ao passo que a absorção ocorre no instante em que ele se projeta mentalmente na experiência.

Essa dimensão pode ser encontrada, por exemplo, em um parque ecológico. A partir do momento em que uma pessoa observa e contempla um parque ecológico à distância, esta pessoa está se envolvendo com o parque de modo a trazer para sua mente as sensações que sentiria caso estivesse presente naquele local (absorção).

Em contrapartida, caso essa mesma pessoa se encontre dentro do parque, seu envolvimento com o ambiente passa a acontecer na forma de uma imersão, ou seja, a pessoa se relaciona com o ambiente num nível muito mais próximo; ela faz parte do ambiente (imersão). De forma breve, na absorção a experiência "vem" até o consumidor, ao passo que na imersão o consumidor "vai" até a experiência (GILMORE; PINE II, 1999).

Cruzando ambas as dimensões é possível determinar quatro domínios da experiência: entretenimento, educacional, estético e escapista, conforme modelo da figura 3 :

Figura 3: Tipos de Experiências

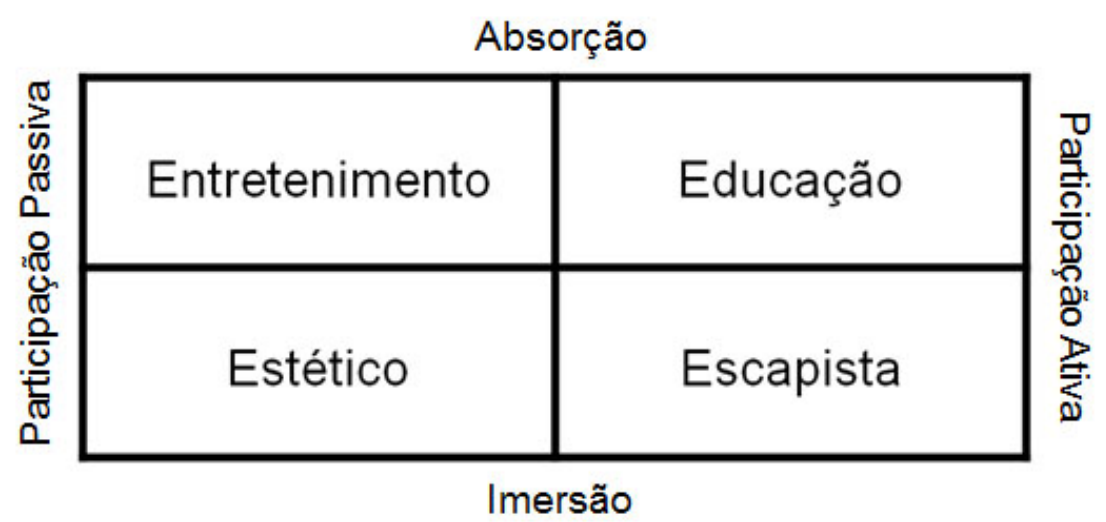

Fonte: Adaptado de PINE II e GILMORE, 1999, p. 40

a) Entretenimento: uma experiência abrange o domínio do entretenimento sempre que um indivíduo absorve passivamente a experiência através de seus sentidos, assistindo ao evento sem influenciar em sua performance. Esse domínio compreende atividades como, assistir à televisão, ir ao cinema, teatro ou circo, ou qualquer outra forma de experiência em que o 
consumidor observe passivamente a realização de uma performance. $O$ entretenimento também pode estar presente em ocasiões menos óbvias como, por exemplo, ir à feira e decidir comprar de um feirante que faz malabarismo com as mercadorias.

b) Educacional: o domínio educacional contempla atividades que engajam a mente e/ou o corpo do consumidor, como atividades que exercitem seu físico (esportes) ou sua mente (aprendizagem). Está presente sempre que uma pessoa absorve a experiência de forma ativa.

Os autores consideram o domínio educacional como sendo ativo, pois afirmam que o processo de aprendizagem é um processo em que a pessoa tem que estar envolvida para aprender de fato. Além das atividades esportivas e de aprendizagem, esse domínio pode englobar fatos simples, como um restaurante que oferece um cardápio infantil com histórias e dicas de alimentação saudável para as crianças.

c) Estético: o domínio estético busca despertar prazeres sensoriais no consumidor, imergindoo em um determinado evento ou ambiente, sem que o consumidor afete pessoalmente o ambiente, ou seja, ele aprecia um ambiente essencialmente intocado. Tanto contemplar uma galeria de arte, como caminhar por um parque ecológico são consideradas atividades pertences a esse domínio.

Em geral, estabelecimentos que se preocupam com o impacto da atmosfera de sua decoração na percepção do consumidor estão se preocupando com este tipo de domínio.

d) Escapista: a ideia que melhor explica o domínio escapista é "fuga da realidade". Neste domínio, o consumidor participa e imerge totalmente no ambiente, afetando a experiência por meio de sua performance ativa e envolvida.

De uma maneira geral, grande parte das experiências desse tipo de domínio leva o consumidor a uma realidade diferente daquela que ele está habituado. Um exemplo disso são os habitantes de capitais que optam por passar o final de semana em um hotel rústico para fugirem das pressões e da realidade dinâmica da cidade. 
Pine II e Gilmore não sugerem, necessariamente, a utilização de um único domínio. Para eles, as empresas podem apresentar aspectos dos quatro domínios - simultaneamente - para enriquecer o efeito de uma mesma experiência.

Um restaurante italiano, por exemplo, pode treinar seus garçons para que cantem canções em italiano ou que gesticulem de maneira similar a um italiano nativo, ao mesmo tempo em que usam roupas tradicionais. A cozinha pode possuir uma parede de vidro (ou até mesmo ser aberta), possibilitando aos clientes assistirem ao pizzaiolo fazer manobras com a massa de pizza enquanto prepara-as. Todos esses aspectos compõem o domínio do entretenimento.

Continuando, a decoração, a arquitetura, os uniformes, a mobília e quaisquer outros aspectos sensoriais desse restaurante podem seguir o tema italiano de cores brancas, verdes e vermelhas (domínio estético).

Mais ainda, caso os clientes tenham interesse, os garçons podem ensinar os consumidores a respeito da cultura italiana ou até mesmo ensinar as canções cantadas por eles. Nos cardápios podem estar presentes algumas histórias regionais ou curiosidade a respeito dos ingredientes utilizados nos pratos. Tais aspectos fazem parte do domínio educacional.

E por fim, fazer uma refeição nesse restaurante já é uma experiência escapista em si, e se intensificaria caso os clientes se envolvessem a tal ponto que cantassem ou dançassem com os garçons e entre eles. Dessa forma, um só negócio pode abranger característica de dois ou mais domínios em sua experiência (PINE II; GILMORE, 1999).

PINE II e GILMORE (1998; 1999) não propõe nenhum modelo, no sentido clássico do termo, para implantação de um projeto de Marketing Experiencial. No entanto, sugerem o que chamam de 5 princípios fundamentais para o design de um projeto experiencial.

a) Criação de um tema: é importante que a experiência seja temática, ou seja, que se crie um assunto, um argumento a ser desenvolvido, que conduza os elementos do projeto na direção de um enredo totalmente unificado, cativando o cliente. Exemplos disto são os temas desenvolvidos, na área de restaurantes, pelo Hard Rock Cafe, Planet Hollywood ou Rainforest Café. 
A cidade de Las Vegas tem uma quantidade enorme de hotéis temáticos, que seguem a ideia básica deste princípio. Abaixo, a tabela ilustra alguns dos hotéis e seus respectivos temas:

Tabela 2 - Hotéis temáticos em Las Vegas

\begin{tabular}{|l|l|}
\hline \multicolumn{1}{|c|}{ HOTEL } & \multicolumn{1}{c|}{ TEMA } \\
\hline MGM & Hollywood \\
\hline Luxor & Egito Antigo \\
\hline Excalibur & Rei Artur \\
\hline Circus Circus & Circo \\
\hline Mandaly Bay & Sudeste Asiático \\
\hline Flamingo & Art-Deco \\
\hline The Palazzo & Europa \\
\hline The Mirage & Polinésia \\
\hline Monte Carlo & Mônaco \\
\hline Treasure Island & Piratas do Caribe \\
\hline Imperial Palace & China \\
\hline Planet Hollywood & Hollywood \\
\hline Caesars Palace & Imperio Romano \\
\hline
\end{tabular}

Fonte: Elaborado pelo autor com base em MGM 2011; LUXOR 2011; EXCALIBUR 2011; CIRCUS CIRCUS 2011; MANDALY BAY 2011; FLAMINGO 2011; THE PALAZZO 2011; THE MIRAGE 2011; MONTE CARLO 2011; TREASURE ISLAND 2011; IMPERIAL PALACE 2011; PLANET HOLLYWOOD 2011; CAESARS PALACE 2011.

b) Harmonização de impressões com deixas positivas: apesar do tema ser o alicerce da experiência, é importante que se ofereça impressões indeléveis, ou seja, para criar a impressão desejada, as empresas devem apresentar sugestões que afirmam a natureza da experiência ao cliente, dando consistência ao tema. Um pequeno exemplo disto é quando a atendente do Rainforest Cafe, ao invés de dizer ao cliente "Sua mesa está pronta," diz "Sua aventura vai começar".

c) Eliminação de deixas negativas: a experiência também deve eliminar qualquer coisa que diminua, contradiga ou se desvie do tema. Para isso, devem-se evitar serviços descuidados, que contradigam a promessa do tema. 
É importante lembrar que, como afirma SHAW (2002), as organizações precisam conhecer as expectativas do consumidor, para que seja possível planejar a experiência de forma a melhor conduzi-la para que a percepção seja positiva. Em outras palavras, as organizações têm de buscar um equilíbrio entre as expectativas estabelecidas na mente do consumidor e a experiência proporcionada.

Caso estabeleça as expectativas de forma muito elevada - sem que a experiência alcance estas expectativas - a organização pode não cumprir com o que foi prometido, frustrando ou desagradando o consumidor. Ao contrário, caso estabeleça-as de forma muito baixa, o consumidor pode não apresentar interesse na experiência ofertada pela empresa.

Esta mesma ideia é defendida por KOTLER e KELLER (2006, p. 142), e também por Grönroos (2009, p. 70) ao explicarem o conceito de "expectativas do cliente".

d) Desenvolvimento de um mix de lembranças: a experiência pode ter um efeito residual na memória das pessoas a partir de alguns produtos que os consumidores compram apenas para lembrar da experiência vivida. São vários os exemplos: camisetas, fotografias, bonés, copos, etc.

e) Envolvimento dos cinco sentidos: Pine II e Gilmore defendem fortemente este ponto, mostrando que, quanto mais sensorial for uma experiência, mais memorável ela será. Por isso, a empresa deve procurar desenvolver ações que envolvam todos os sentidos humanos, a partir do tema criado.

Pine II e Gilmore deixam claro que a utilização destes princípios, por si só, não são garantia de sucesso. As outras variáveis incontroláveis da economia de mercado continuam existindo.

Mais ainda, afirmam que a economia da experiência vai passar pelo mesmo processo que passou a economia dos bens e dos serviços, ou seja, uma grande proliferação de ofertas ou, como citam os autores, o crescimento será através do que o economista Joseph Schumpeter chamou de "tempestades de destruição criativa", isto é, a inovação de negócios, que ameaça tornar irrelevantes os que se relegam ao mundo cada vez menor de bens e serviços. 


\subsubsection{Bernd H. Schmitt - O Conceito de Marketing Experiencial}

Inicialmente, o autor que viria a conceber o termo "marketing experiencial" - Bernd $\mathrm{H}$. Schmitt - restringia sua visão de experiência a aspectos sensoriais e estéticos.

Para o autor, como a maioria dos consumidores não se impressionava mais com características e benefícios isolados, as experiências sensoriais surgiam como alternativa a essa situação, proporcionando valores estéticos e qualidades atraentes por meio de uma identidade visual que tenha significado para os consumidores (SCHMITT; SIMONSON, 1997).

Em 1999, em seu artigo para o Journal of Marketing Management - “Experiential marketing” - Schmitt mostra que:

"Experiences occur as a result of encountering, undergoing or living through things. Experiences provide sensory, emotional, cognitive, behavioural, and relational values that replace functional values." (SCHMITT, 1999, p. 57).

Em geral, a experiência deriva de uma observação direta e/ou participação nos acontecimentos reais, virtuais ou imaginários; ou seja, é a decorrência de uma interação material e/ou abstrata.

A observação direta ocorre no momento em que um consumidor visualiza algo ou algum acontecimento, ocorrendo, por exemplo, no momento em que um consumidor assiste a um comercial na televisão.

Já as participações reais, imaginárias e virtuais dizem respeito ao contato que um consumidor tem com uma situação. Dessa forma, dirigir um automóvel, acessar um determinado site da internet, ou se imaginar em um show de música - por serem ocasiões em que um consumidor interage diretamente com determinado produto ou situação -, podem ser consideradas como experiências de participação real, virtual e imaginária, respectivamente. 
SHAW e IVENS defendem um conceito semelhante ao afirmarem que "a experiência não trata somente do material, do emocional ou do sensorial, ela é composta pela combinação de todos esses aspectos juntos" (2002, p. 6).

Schmitt defende que as experiências "são acontecimentos individuais que ocorrem como resposta a algum estímulo" (SCHMITT, 1999). Estes estímulos provocam diferentes reações no consumidor, sendo capazes de afetar seus sentidos, seus sentimentos e/ou sua mente.

As reações sensoriais ocorrem no momento em que o consumidor reage a um estímulo percebido por seus sentidos, como é o caso da pessoa que entra em uma lanchonete ao sentir o cheiro de um determinado sanduíche ou bolo.

As reações emocionais (dos sentimentos) e cognitivas (da mente) originam-se da reação a um estímulo, e resultam na alteração do estado emocional e mental da pessoa. Essas reações podem ter como origem, por exemplo, a interação entre um consumidor e o funcionário de uma loja.

Caso o funcionário se comporte de forma imprópria, o consumidor pode apresentar diferentes sentimentos, como frustração ou desapontamento. Entretanto, caso o funcionário atenda-o de forma diferenciada, essa interação pode perdurar na mente do consumidor durante considerável período de tempo.

Assim sendo, como o controle desses estímulos em geral está ao alcance das organizações, as experiências não são espontâneas, mas induzidas, ou seja, elas têm referencial e intencionalidade.

É evidente que existem experiências que são espontâneas, já que determinados estímulos não são passíveis de manipulação - é o caso, por exemplo, de uma árvore que cai em cima de um trailer que vende sucos. O dono do trailer não planejou a queda da árvore - entretanto, essa situação afetou a percepção do consumidor que comprava algo naquele momento.

Por fim, as experiências fazem com que as atitudes e as ocasiões de compra e consumo, por parte do consumidor, componham um contexto social mais amplo. Ou seja, deve-se deixar de 
enxergar os produtos sob uma perspectiva isolada para, ao invés disso, avaliar a situação geral de consumo e seu significado inerente.

Sob uma perspectiva isolada, a finalidade de um carro se baseia na locomoção de uma pessoa para um determinado lugar. Contudo, considerando o significado da situação de consumo, um indivíduo pode optar por dirigir um carro por uma série de outros diferentes motivos como, por exemplo, pelo status proporcionado pelo carro, pelo estilo de vida que esse indivíduo encena junto ao carro, ou pela simples possibilidade de reunir amigos e socializar junto ao carro (SCHMITT, 2000).

Após conceituar as experiências, Schmitt as divide em cinco diferentes tipos, denominando-as de Modelos Experienciais Estratégicos (MEEs). Estes Modelos são partes singulares e específicas que compõem uma experiência, "cada qual com seus próprios processos e estruturas inerentes" (SCHMITT, 2000, p. 77).

Em outras palavras, as experiências envolvem cinco componentes distintos entre si, cada qual com funcionamento singular em relação às outras. Assim, as experiências podem conter ou não determinados modelos, ou seja, as experiências são combinações dos MEEs.

Os cinco MEEs - Modelos Experienciais Estratégicos - propostos por Schmitt são: Modelo Sensorial, Modelo Emocional, Modelo Cognitivo, Modelo Comportamental e Modelo Relacional (SCHMITT, 2000). A seguir, uma explicação resumida de cada um deles:

a) Modelo Sensorial: Os modelos sensoriais representam a parte da experiência que faz apelo a um ou mais sentidos do consumidor - visão, tato, olfato, audição e paladar.

Schmitt destaca que, devido à relativa facilidade na manipulação de estímulos provenientes desse modelo, uma quantidade considerável de organizações se dedica unicamente ao planejamento de experiências sensoriais, deixando os outros quatro tipos de experiência ao acaso.

Existem inúmeras situações onde os modelos sensoriais são encontrados: nos produtos e em suas embalagens, nos uniformes de funcionários, nos ambientes e na arquitetura de estabelecimentos, nas peças publicitárias, entre outras. 
Partindo para um exemplo mais específico desse modelo: uma série de estímulos pode caracterizar a presença de uma experiência sensorial em um restaurante, como o cheiro e o gosto da comida, a apresentação dos pratos, o estofamento das cadeiras, a luminosidade do lugar, o tipo de música presente, a decoração do estabelecimento ou a textura do papel utilizado no cardápio.

Um automóvel pode também envolver diferentes sentidos: seu design (visão), o material dos seus assentos (tato), o som que a porta faz quando fecha (audição) e o cheiro característico do carro quando ainda é novo (olfato) são elementos que devem ser considerados, visto que afetam a experiência de um consumidor.

b) Modelo Emocional: Os modelos emocionais são aqueles que fazem apelo aos sentimentos e às emoções pessoais do consumidor. As experiências emocionais abrangem tanto dimensões conscientes como subconscientes, e compreendem desde emoções passageiras até sentimentos duradouros, possibilitando a criação ou não de vínculos emocionais entre uma pessoa e uma determinada organização.

O grau de intensidade das experiências emocionais varia conforme o estado de espírito do consumidor e a situação de consumo, ou seja, o temperamento e a predisposição emocional de um indivíduo ao entrar na experiência afetam a maneira e a intensidade dos seus sentimentos.

Por exemplo, pessoas com temperamentos bastante divergentes - como indivíduos calmos, em comparação com pessoas caóticas - tendem a perceber experiências semelhantes de formas distintas.

Ademais, a predisposição emocional de um consumidor também é relevante nessa análise: uma pessoa com problemas no trabalho ou que tenha recém terminado um relacionamento pessoal adentra determinada experiência com seu estado emocional instável, podendo comprometer sua percepção ao longo do desenvolvimento da experiência.

Exemplificando uma situação na qual as experiências emocionais estão presentes: quando um indivíduo consome determinado produto (um sorvete) em certa ocasião (seu casamento), as associações resultantes dessa experiência podem provocar vínculos emocionais entre esse indivíduo e o produto em questão. 
O momento da interação entre um funcionário e o consumidor também representa uma experiência emocional, dado que uma série de emoções é invocada no consumidor ao longo e ao término desse contato.

Outro exemplo de experiência emocional diz respeito à interação entre uma criança e um personagem de um parque temático (pessoa fantasiada). Para a criança, além dos aspectos sensoriais presentes, como o visual do personagem ou a maciez de sua fantasia, grande parte da experiência ocorre através de seus sentimentos, visto que ela pode ser acometida por um sentimento extremamente agradável por ver um personagem que lhe cativava em meio a historias que seus pais contam ou filmes que ela assiste.

Ao contrário, essa mesma interação pode representar um momento de aflição e medo para a criança, pois ela pode não se sentir confortável perto do personagem em questão, invocando o sentimento de medo ou receio em relação à pessoa fantasiada.

c) Modelo Cognitivo: Os modelos cognitivos fazem apelo ao intelecto, engajando o consumidor em pensamentos elaborados e criativos. Em outras palavras, esse modelo inclui experiências que envolvam mentalmente o consumidor na situação de consumo, situando o produto, o serviço ou situação em questão em sua mente.

Segundo Schmitt, esse modelo pode engajar um consumidor em dois tipos de pensamentos: os convergentes e os divergentes. O pensamento convergente envolve aspectos racionais bem definidos, ou seja, engloba pensamentos analíticos e probabilísticos. Em geral, análises sistemáticas de um problema caracterizam esse tipo de modelo cognitivo.

Já o pensamento divergente é mais livre, estando associado à habilidade de gerar muitas ideias, mudar de perspectiva e/ou criar ideias originais.

Há de se considerar que ambos os tipos de pensamento são estimulados de maneiras distintas: um espetáculo de teatro pode despertar pensamentos convergentes e divergentes.

Diversas imagens e ideias podem surgir na mente do consumidor no momento em que ele está assistindo a uma peça, entretanto, ao se questionar quanto à qualidade da estrutura física do teatro - poltronas desconfortáveis, luminosidade precária, banheiros sujos, palco distante ou 
grandes filas na bilheteria - pode concluir racionalmente que a experiência do teatro não é tão boa quanto ele acreditava ser ao entrar e assistir a peça.

A experiência cognitiva também pode estar presente em uma peça publicitária: no momento em que o consumidor lê um folheto, além de pensar se o produto comunicado apresenta alguma finalidade para ele, esse consumidor pode se perguntar em relação à validade do folheto, se indagando se de fato o produto faz o que a comunicação está dizendo ou se é apenas outro truque para enganá-lo e induzi-lo a compra.

d) Modelo Comportamental: Os modelos comportamentais criam experiências relacionadas ao corpo do consumidor, modificando seus padrões de comportamento, promovendo interações pessoais e/ou proporcionando opção de estilos de vida.

Dessa forma, esse modelo compreende atividades que afetem o corpo do consumidor em dimensões individuais ou compartilhadas, ou seja, que se limitam unicamente ao indivíduo ou que envolvam outras pessoas. Schmitt menciona a existência de oito diferentes categorias de experiências de ação: aspectos físicos, ações motoras, sinais corporais, influência do ambiente sobre desejos físicos, estilos de vida, comportamento não-verbal, autopercepção, mudanças comportamentais e indução de ações não pensadas.

Essas categorias são distribuídas ao longo de dois grupos; as associadas ao corpo e as ligadas ao estilo de vida. Em relação às associadas ao corpo, dizem respeito a qualquer atividade que se limite a aspectos corporais e/ou motores do consumidor, enquanto as ligadas ao estilo de vida compreendem as situações em que há mudança do comportamento ou da autopercepção do indivíduo.

As experiências comportamentais estão presentes, por exemplo, em restaurantes vegetarianos. Nesse tipo de restaurante as pessoas alteram seu estado corporal por meio de uma alimentação saudável, visto que esses alimentos geralmente trazem benefícios à saúde e contribuem no condicionamento físico e mental.

Entretanto, há de se mencionar que, apesar de não contribuírem para saúde, as redes americanas de fast-food também são exemplos de experiências comportamentais, dado que 
modificam aspectos físicos do corpo do consumidor, mesmo que no sentido contrário (da má alimentação).

É importante deixar claro que, em nossa opinião, muitas vezes Schmitt tem uma postura muito radical, seja para ilustrar seus conceitos, seja para questionar o conceito tradicional de marketing, como veremos adiante.

Este é um exemplo típico desta visão: o Modelo Comportamental proposto por Schmitt faz todo sentido dentro do conceito de Modelos Experienciais Estratégicos desenvolvidos. No entanto, a exemplificação deste conceito pela experiência nos restaurantes vegetarianos e de fast-food parte de uma premissa parcial, que parece estar muito mais ligada às preferências pessoais do autor. Isto porque nem todo fast-food pode ser considerado como não saudável, bem como nem toda alimentação vegetariana traz apenas benefícios.

É evidente que o objetivo deste ponto não é discutir benefícios e prejuízos de determinadas formas de alimentação. Está claro qual o conceito de experiência comportamental, bem como sua adequação dentro do Modelo proposto.

A observação acima, a respeito dos diferentes tipos de restaurantes é apenas para pontuar a visão do radicalismo que, como dissemos, muitas vezes é adotado pelo autor.

Outra ocasião onde as experiências comportamentais estão presentes é na compra de um carro. Ao adquirir um modelo esportivo, o consumidor pode passar a agir como se possuísse mais confiança, agindo de uma maneira desinibida se comparado com a forma como se comporta habitualmente. Isso pode ser provocado pelo fato do consumidor "encenar" outro estilo de vida nos momentos em que se encontra dirigindo o carro, visto que, por ser um modelo esportivo, pode projetar em si a jovialidade ou a imagem de bem sucedido que o carro transmite para ele.

Em outras palavras, ao passar pela experiência junto ao modelo de carro esportivo, o consumidor se comporta de maneira diferente da habitual, em função do estilo de vida projetado pelo carro no consumidor. 
e) Modelo Relacional: Os modelos relacionais desenvolvem ligações entre o consumidor, o contexto social e a organização, relacionando-o com seu self ou com outras pessoas e culturas.

As experiências relacionais apresentam aspectos dos outros quatro modelos experienciais, entretanto vão além de sua simples soma. Eles representam algo maior do que a totalidade dos outros modelos pois estabelecem vínculos com outras pessoas e culturas, ou seja, extrapola a habitual relação entre indivíduo e empresa. Assim, o objetivo desse tipo de modelo é desenvolver ligações entre o cliente, a marca e o significado social em questão.

Dentro desse modelo estão presentes grupos sociais mais específicos, como pessoas da mesma crença, estilo de vida e profissão, e grupos sociais mais abstratos, como pessoas de um mesmo país, sociedade ou cultura.

Esses grupos sociais são importantes para o consumidor pois atribuem um senso de identidade social definida como "a parte do autoconceito que sofre influência na participação de um grupo social”. (SCHMITT, 2000, p. 181).

As experiências relacionais estão presentes, por exemplo, no momento em que um grupo de amigos vai à livraria. Na ocasião em que essas pessoas se encontram nesse estabelecimento, elas passam a interagir em função do momento em que começam a buscar - juntas - por livros que as agradem, debatendo a respeito de livros interessantes ou conhecendo novas pessoas durante esse processo de interação.

Assim como a livraria, uma pessoa que busca comprar uma moto com o intuito de poder ser aceita por determinado grupo - por exemplo, um grupo de motoqueiros -, está passando por uma experiência relacional (SCHMITT, 2000).

Para Schmitt, as organizações não precisam objetivar a utilização de um único modelo experiencial, já que quanto maior a quantidade de MEEs presentes, maior o apelo da experiência para o consumidor. A combinação de dois ou mais modelos experienciais é chamada por Schmitt como "experiência híbrida." 
Quando as experiências integram qualidades de modelos sensoriais, emocionais, comportamentais, cognitivos e relacionais - simultaneamente -, então essa é a "experiência holística".

As experiências holísticas podem incidir, por exemplo, no momento em que um indivíduo decide comprar uma peça de roupa. Neste caso, o modelo sensorial pode estar presente na fachada da loja, na decoração interna, na música ambiente, no uniforme dos funcionários, nos aromas da loja ou nos próprios produtos. Esse modelo pode envolver um produto (peças de roupa) com diferentes sentidos, como a textura da roupa (tato), seu cheiro (olfato) ou sua aparência (visão).

O modelo emocional pode ter origem na interação entre o consumidor e os funcionários da loja ou nos vínculo e associações emocionais que o consumidor tem com determinado produto. Em outras palavras, caso o consumidor não seja atendido adequadamente por um funcionário, esse contato pode gerar um sentimento de frustração para ele, gerando uma experiência emocional negativa.

O modelo cognitivo pode advir da reflexão após a compra do consumidor, das lembranças da ocasião de compra ou na ativação da imaginação do cliente ao se imaginar utilizando determinada peça de roupa.

Uma pessoa que, ao olhar pela vitrine, se imagina vestindo um produto específico dessa loja está sendo envolvido por uma experiência cognitiva. Em relação ao modelo comportamental, um consumidor pode desejar um estilo de vida por meio da aquisição de um produto da loja.

Por exemplo, alguém que busca para si a imagem de roqueiro pode preferir por se vestir de roupas da cor preta, devido à associação que esse tipo de traje proporciona.

Por fim, os modelos relacionais estão presentes caso os produtos produzam o sentimento de pertencer a determinado grupo social. Seguindo o exemplo do roqueiro, se essa mesma roupa preta possibilitar o consumidor a participar de determinado grupo (de roqueiros), então o modelo relacional está presente na experiência da dessa loja (SCHMITT, 2000). 
Para executar as ações de modelos estratégicos, o autor sugere a criação de Provedores de Experiências (proexps), que são componentes táticos de uma organização que possibilitam a ocorrência das experiências. Ou seja, uma experiência é proporcionada por meio de provedores de experiências (SCHMITT, 2000).

As experiências podem envolver diferentes tipos e quantidades de proexps, variando em função da complexidade da situação de compra ou consumo.

Por exemplo, a compra de uma determinada marca de papel higiênico abrange apenas um provedor de experiência (o próprio produto), ou seja, a experiência proporcionada por esse produto se limita à interação entre o consumidor e o papel higiênico podendo, eventualmente, sofrer a influência de um segundo proexps, como uma peça publicitária da marca.

De maneira contrária, a situação de compra de um carro - geralmente - proporciona uma quantidade consideravelmente maior de contatos entre um consumidor e diferentes proexps.

Citando alguns possíveis proexps: as peças publicitárias veiculadas em diferentes mídias, os atendentes e funcionários das concessionárias, o site da marca, ambientes de merchandising e outras ações promocionais no ponto de venda, a aparência do ambiente interno e externo da concessionária e, principalmente, o próprio carro.

Dessa forma, os proexps não só proporcionam a experiência de um produto ou serviço específico, como também são uma forma de interação entre o consumidor e a marca detentora do produto. De acordo com Schmitt, os proexps podem ser distribuídos em sete principais grupos, como veremos a seguir: (SCHMITT, 2000).

a) Comunicação: ações de comunicação e peças publicitárias, incluindo a propaganda, comunicações internas e externas da empresa e as campanhas de relações públicas.

b) Pessoas: são todos os funcionários ou representantes da organização que entram em contato com o consumidor. Dentre os mais usuais, podem-se citar os vendedores, representantes da empresa e prestadores de serviços. 
A proposta de Schmitt de colocar as pessoas como um grupo de proexps é semelhante ao conceito de "momentos da verdade", defendido por CARLZON (2005).

c) Web-site e mídia eletrônica: esses provedores de experiências representam toda forma de interação com um cliente por meio de sites da internet. Nesse item estão inclusos sites especializados, salas de chat, leilões virtuais, dentre outros.

d) Ambientes espaciais: são proexps presentes nas estruturas físicas pertencentes à organização, como prédios, estruturas, fábricas, lojas, espaços públicos ou feiras comerciais.

e) Co-marcas: as co-marcas dizem respeito aos provedores de experiência resultantes de qualquer aliança ou pareceria entre diferentes marcas. São exemplos de parcerias: marketing de evento e patrocínio, as alianças e sociedades, licenciamentos, inclusão de produtos em filmes e televisão e campanhas comunitárias.

f) Identidade visual e verbal: são proexps compostos por elementos visuais ou verbais que conduzem o consumidor à associação mental de determinada marca ou empresa. Dentre os elementos que compõe esses provedores de experiências, tem-se os nomes, os logotipos, os sinais e símbolos, os códigos e a tipografia da marca.

g) Presença do produto: diz respeito aos provedores de experiência que se baseiam no produto para proporcionar experiências ao consumidor. A presença do produto se faz por meio do design, da embalagem, do display do produto, dos materiais do ponto de venda e do produto em si

Como abordado, o conceito de Provedores de Experiências (proexps) proposto por Schmitt é praticamente o mesmo que o conceito de Pontos de Contato, definido por KOTLER e KELLER (2006, p. 151) como "qualquer ocasião em que o cliente tem contato com a marca ou o produto - isso inclui desde uma experiência em si até uma comunicação pessoal ou de massa, ou mesmo uma observação casual."

Bastante similar ao conceito de Schmitt está o raciocínio de SHAW (2002), que mostra que as experiências podem ser fragmentadas em diferentes situações de interação entre um consumidor e uma organização. Essas interações são chamadas de momentos de contato, e 
podem ser definidos como os eventos da experiência na qual um consumidor interage ou se relaciona diretamente com uma organização. Dentre os diversos exemplos de momentos de contato pode-se mencionar sites ou propagandas na internet, equipes de vendas, propagandas veiculadas em mídias impressas ou eletrônicas, funcionários, estabelecimentos e veículos da organização ou seus próprios produtos e serviços.

Pouco tempo depois, Schmitt desenvolve o conceito de Gestão da Experiência do Cliente (GEC), definindo-o como "o processo no qual se gerencia, estrategicamente, toda a experiência de um consumidor com determinado produto ou empresa". (SCHMITT, 2004, p. 27)

Este conceito aborda tanto aspectos internos, quanto externos à empresa, ao longo de cada ponto de contato, que são os momentos em que a organização e o consumidor interagem entre si, trocando estímulos simultaneamente.

Nesse processo, a empresa mapeia e administra todos os momentos em que um consumidor possa vir a interagir com ela, indo desde questões abrangentes (a peça publicitária a ser veiculada) até detalhes mais específicos (a cor das cortinas da loja), com o intuito de melhorar o foco de suas experiências no cliente.

Além de considerar as experiências proporcionadas aos consumidores, a GEC leva em conta a experiência interna que afeta os funcionários, visto que são eles um dos elementos que proporcionam as experiências para os consumidores.

\subsubsection{Comentários sobre a visão crítica de Schmitt}

O termo "marketing tradicional” é usado por Schmitt, que o define como sendo

"um conjunto de princípios, conceitos e metodologias que os acadêmicos, praticantes (diretores de marketing, gerentes de marcas e comunicação) $e$ consultores de marketing criaram - principalmente nos últimos 30 anos”, (SCHMITT, 2000 - p. 28) 
Schmitt faz uma dura crítica ao que chama de "marketing tradicional", elencando algumas características que ele considera erradas e/ou ultrapassadas.

Cabe neste ponto analisar as críticas feitas por Schmitt e a comparação que ele faz entre os conceitos de "marketing tradicional" e o seu conceito de Marketing Experiencial.

Por ser o criador do termo Marketing Experiencial, Schmitt muitas vezes tem opiniões um pouco radicais, viesadas por crenças pessoais que acabam por superestimar o conceito de experiência em detrimento ao modelo tradicional. Por outro lado, também é verdade que algumas de suas colocações fazem sentido quando alguns dos problemas que ainda existem na aplicação dos conceitos de marketing são observados na prática das organizações. Os principais pontos de comparação são:

\subsubsection{Foco nas características funcionais e benefícios}

Schmitt critica fortemente o fato do marketing tradicional focar excessivamente nas características dos produtos e os benefícios resultantes destas características. O marketing tradicional pressupõe que os clientes de diversos mercados - sejam eles consumidores finais ou organizacionais - "avaliam as características funcionais de acordo com seu grau de importância, avaliam a presença das características do produto e escolhem o produto que tenha maior utilidade geral (definida como a soma das características ponderadas)" (SCHMITT, 2000, p. 29).

Segundo Schmitt, tudo que não se encaixa em características funcionais ou benefícios é rotulado como sendo "imagem" ou "marca", sem que haja uma compreensão mais precisa da situação de consumo.

Como se pode perceber, essa crítica se assemelha consideravelmente ao que Holbrook e Hirschman propõem ao longo de seu artigo "The experiential Aspects of Consumption: Consumers Fantasies, feelings and fun", visto que ambos os autores criticam o excesso de objetividade do modelo tradicional. 
Como alternativa, Schmitt sugere às organizações que foquem também nas experiências do consumidor, ao invés de somente considerar características e benefícios. Para Schmitt, a compra de uma bicicleta, segundo o marketing tradicional, considera apenas características e benefícios, como a quantidade de marchas, a qualidade dos pneus ou a capacidade da bicicleta em levar uma pessoa a seu destino. Ao contrário, o marketing experiencial leva em conta o que a bicicleta significa para o consumidor como, por exemplo, um estilo de vida aventureiro ou ecológico (SCHMITT, 2000).

Nesta primeira crítica já se pode perceber que os argumentos de Schmitt são, por vezes, um tanto quanto radicais - isso poderá ser constatado novamente em alguns dos próximos pontos.

A conclusão de Holbrook e Hirschman parece mais equilibrada, pois os autores percebem que a perspectiva experiencial e os aspectos hedônicos do consumo devem complementar e ampliar os modelos tradicionais que focam as características e benefícios dos produtos e serviços. Até mesmo porque, usando o mesmo exemplo de Schmitt, uma bicicleta que simbolize um estilo de vida aventureiro para determinado consumidor, deve possuir um mínimo de características, como marchas e pneus, que efetivamente suportem um passeio de aventura.

A proposta de Schmitt, para que as organizações pesquisem de maneira mais profunda o significado do consumo, não limitando este significado a termos que, na visão dele, são por demais genéricos, como imagem e marca, parece interessante e apropriado, ainda mais quando se percebe que a questão hedônica é cada vez mais presente.

Este raciocínio parece bastante radical, na medida em que o Marketing não tem essa visão puramente utilitarista. Existem diversas publicações de marketing que podem ser usadas para se contrapor a este argumento. Ou seja, Schmitt não é o único e nem mesmo o pioneiro a fazer esta proposta. São vários os conceitos e autores de marketing que comungam dessa visão. Isto pode ser visto desde os conceitos de comportamento do consumidor, marca, desejos e necessidades, desenvolvimento de produto, etc...

GORZ (2005), por exemplo, mostra que, se por um lado, as necessidades das pessoas eram limitadas por natureza, por outro lado seus desejos eram essencialmente ilimitados. 
Consequentemente, quanto mais os produtos satisfizessem desejos emocionais, além das necessidades materiais, maior seria o nível de consumo dos indivíduos.

O próprio conceito de Comportamento do Consumidor, em suas diferentes abordagens, aborda as questões emocionais. Isto pode ser visto em SOLOMON (2002), LINDSTROM (2009), ARIELY (2008), SCHWERINER (2006) e SHETH (2001).

\subsubsection{Definição restrita de concorrência e categorias de produto}

Segundo Schmitt, para o marketing tradicional a concorrência se dá essencialmente entre marcas com produtos semelhantes, buscando satisfazer os desejos de seus consumidores de formas similares. Ou seja, um fabricante de refrigerantes concorre essencialmente com outros fabricantes de refrigerante. Segundo o marketing experiencial, faz-se necessário examinar a situação de consumo na qual um produto ou serviço está presente e seu significado.

Assim, levando em conta a situação de consumo, é possível constatar que marcas de refrigerantes não se limitam a competir com outras marcas de refrigerantes, mas concorrem com outras ofertas que tenham a finalidade de hidratar, refrescar, matar a sede ou que tenham um gosto agradável. Sob a ótica da situação de consumo, passam a ser considerados concorrentes: marcas de água, sucos, energéticos, bebidas alcoólicas, ou até mesmo sorvetes, ventiladores e piscinas, visto que possibilitam ao cliente satisfazer seu desejo de se refrescar (SCHMITT, 2000).

Este argumento de Schmitt não se sustenta, e parece estar baseado numa visão parcial e equivocada. A definição restrita de concorrência vem sendo criticada pelo marketing há, no mínimo, 50 anos, quando LEVITT (1960) escreveu seu clássico artigo "Miopia em Marketing", mostrando a importância fundamental das empresas definirem seus negócios numa perspectiva mais macro em termos de setor de atuação, ou seja, Levitt já defendia a importância de se olhar também os produtos diferentes que satisfaziam as mesmas necessidades. 
Outro que trabalha esta questão é KOTLER (2000; p. 36/37), ao estabelecer quatro níveis de concorrência com base no grau em que os produtos são passíveis de substituição: concorrência de marcas, concorrência setorial, concorrência de forma e concorrência genérica.

PORTER (1986; p.24), na sua clássica análise da indústria, defende que "a concorrência em uma indústria não está limitada aos participantes estabelecidos. Clientes, fornecedores, substitutos e entrantes potenciais são todos concorrentes... e, nesse sentido mais amplo pode ser definido como rivalidade ampliada."

Indo um pouco mais além, esta visão ampliada de concorrência é apresentada por CONNELLAN (1998; p. 30), que afirma que "concorrente é qualquer empresa com a qual o cliente o compara". Este conceito é bem mais abrangente, pois fornece uma visão a partir do ponto de vista do consumidor.

Neste sentido, quando um consumidor entra em um banheiro de estádio de futebol, resgata outras situações similares em sua memória, como o banheiro de outro estádio, de um bar, de um restaurante, de um shopping ou de uma estação do metrô, por exemplo. Dessa forma, a aparência do banheiro será comparada não somente com outros banheiros de estádio de futebol, mas com ocasiões similares, como as expostas acima.

SHAW (2002) afirma que quando os consumidores passam por uma experiência, eles processam subconscientemente os eventos dessa experiência, realizando uma série de julgamentos e comparações com eventos passados similares. Ou seja, as pessoas constroem expectativas com base em situações relativamente similares do passado, servindo de referência para ações e julgamentos futuros.

\subsubsection{Clientes como tomadores de decisões racionais}

Novamente concordando com as teorias de Holbrook, Schmitt critica o excesso de racionalidade nos modelos de decisão de compra do consumidor, alegando que não consideram ações afetivas e inconscientes presentes nas situações de consumo. 
Ao contrário do marketing tradicional, o experiencial considera tanto a racionalidade das decisões de compra, como a presença de sentimento e emoções no processo de decisão de compra, o que o torna uma abordagem mais completa do que a anterior. Para o marketing tradicional, a compra de um carro se faz com uma série de etapas racionais, onde o consumidor leva em conta características que resultam na maximização de benefícios. (SCHMITT, 2000).

Complementando essa visão, o marketing experiencial considera que o carro, além de um conjunto de características e benefícios, representa também um objeto de desejo com significado, refletindo personalidade do consumidor que o conduz. Em outras palavras, há um contexto social por trás da experiência de se dirigir um carro, não apenas uma finalidade de transporte ou locomoção (SCHMITT, 2000).

Mais uma vez Schmitt é parcial, pois o fato das pessoas não tomarem decisões meramente racionais, e isto ser explorado pelas organizações, se constitui numa das maiores críticas que se faz à chamada Sociedade do Consumo.

Apenas para exemplificar, COSTA (2004), mostra que o consumismo é um dos principais traços da consolidação da chamada cultura de consumo, na medida em que o que parece ser desperdício, numa visão utilitarista é, na verdade, a busca de prazer e satisfação para muitos indivíduos. Em uma sociedade em que os indivíduos associam consumo à felicidade, a insatisfação emocional, junto à necessidade utilitária, constitui a origem do consumismo.

Outro autor que podemos usar para contestar a visão parcial de Schmitt é Featherstone, que afirma que:

“as pessoas usam as mercadorias de forma a criar vínculos ou estabelecer distinções sociais. Há também a questão dos prazeres emocionais do consumo, os sonhos e desejos celebrados no imaginário cultural consumista e em locais especificos de consumo que produzem diversos tipos de excitação física e prazeres estéticos” (FEATHERSTONE, 2005)

Por outro lado, se analisando os conceitos desenvolvidos na comunicação de marketing, observa-se que vários autores mostram diferentes abordagens para a criação de peças 
publicitárias que enfatizam aspectos muito mais emocionais do que racionais. Isto pode ser visto em SHIMP (2009) e O'GUINN (2008), quando eles mostram, por exemplo, o uso do sexo, do medo e da culpa na criação de mensagens.

BELCH e BELCH (2008) também mostram os diferentes apelos emocionais que as mensagens publicitárias podem ter, indo desde estados pessoais ou sentimentos, como amor, afeição, saudade, orgulho, ambição e outros, até sentimentos com base social, como status, aceitação, rejeição, reconhecimento, etc... (BELCH; BELCH, 2008, p. 266 a 275)

Por outro lado, também é importante lembrar que, em determinadas situações, como em boa parte das compras B2B, em alguns bens de especialidade, e mesmo em venda para Governo, o lado racional tende a ser mais forte na decisão de compra, pelas próprias características dos produtos e dos participantes do processo de compra.

Portanto, como já exposto acima, parece que a visão de Holbrook é mais equilibrada, na medida em que a compreensão da dinâmica do mercado pode ser feita de maneira mais completa quando se utiliza tanto a visão utilitária, como a perspectiva experiencial.

\subsubsection{Excesso de métodos analíticos, quantitativos e verbais:}

Schmitt também critica o excesso de métodos e ferramentas analíticas, quantitativas e verbais, novamente criticando a limitação dessas metodologias objetivas. Argumenta que métodos como os modelos de regressão, mapas de posicionamento, análise de conjunturas e até mesmo pesquisas de marketing focam em aspectos funcionais da decisão, contando com escalas quantitativas para medir situações qualitativas.

Já o marketing experiencial aproveita-se de métodos e ferramentas mais ecléticos, diversificados e multifacetados, "não estando presos a uma única ideologia metodológica" (SCHMITT, 2000, p. 44), ou seja, as ferramentas mais adequadas dependem do objetivo de marketing. Dessa forma, uma pesquisa normalmente realizada com perguntas verbais e extensos questionários escritos pelo marketing tradicional, a fim de descobrir a preferência dos consumidores, pode simplesmente passar para uma observação da situação de consumo de clientes junto a determinados produtos (SCHMITT, 2000). 
Este é outro ponto em que Schmitt também se equivoca. A ideia que passa é que a visão que o autor tem do marketing tradicional é bastante limitada.

É evidente que o marketing dispõe de uma série de ferramentas analíticas e quantitativas que, se bem usadas, podem fornecer importantes contribuições para a melhoria do processo de tomada de decisão.

Porém, o marketing não fica restrito somente a estas ferramentas. Existem diversos tipos de pesquisa que usam ferramentas que vão além dos métodos criticados por Schmitt. Dentre essas, podemos destacar as pesquisas qualitativas, em suas diversas formas.

BARTELS (1988) mostra que, já na década de 50, percebia-se que várias questões de marketing não estavam sendo resolvidas de maneira satisfatória pelos métodos de pesquisa que vinham sendo usados.

Para isso, inicia-se um uso cada vez maior nas pesquisas de mercado de métodos empregados nas ciências sociais, com destaque para conceitos e técnicas da psicologia e sociologia como, por exemplo, associação de palavras, teste de Rorschach, percepção temática, técnicas projetivas, entrevistas em profundidade, focus group, etc...

A própria ideia de Sistema de Inteligência de Marketing (KOTLER, 2000) que, por definição, tem características "caóticas", ou seja, não segue a estrutura rígida de uma pesquisa quantitativa mostra a parcialidade da análise de Schmitt.

\subsubsection{Marcas como meras identificadoras de produtos:}

Schmitt afirma que, no marketing tradicional, a função das marcas reside puramente na identificação de produtos; indicando seu proprietário e diferenciando-se de outros produtos. Já no marketing experiencial, as marcas apresentam associações sensoriais, afetivas e cognitivas, resultando em experiências compensadoras e memoráveis para o consumidor, além da função de identificação. 
Em outras palavras, as marcas, por si só, são fornecedoras de experiências, pois todos os elementos de uma marca compõem a percepção do consumidor em relação à experiência. Um exemplo desse conceito se faz presente na indústria de fabricantes de chocolates, onde as marcas de baixa qualidade buscam apenas identificar seus produtos - baratos e acessíveis -, ao passo que uma fabricante belga não somente identifica a marca e o lugar de fabricação de seus chocolates; como também proporciona uma experiência de sociabilidade e sofisticação (SCHMITT, 2000).

Mais uma vez a crítica de Schmitt parece radical. Já faz muito tempo que as marcas deixaram de ser meras identificadoras de produtos para assumirem um conceito mais amplo, mais simbólico. Isso é facilmente percebido nos trabalhos de BEDBURY (2002), LINDSTROM (2007) e AAKER (2000), só para citar alguns.

\subsubsection{Problemas do conceito de marketing:}

Schmitt também mostra que, apesar de um número considerável de organizações afirmar que são "orientadas para seus clientes", somente uma minoria realmente exerce esse discurso e procura de fato conhecer as necessidades e desejos que motivam os consumidores.

Ou seja, para Schmitt, o marketing tradicional se aproveita de termos como "orientado para o cliente", mas essencialmente foca suas operações em produtos, tecnologias ou vendas. Dessa forma, para melhor proporcionar experiências a seus consumidores, a organização deve compreender as reais necessidades do cliente, a fim de adequar-se a suas vontades e desejos.

Schmitt também critica as estratégias de diferenciação do marketing tradicional, visto que, em geral, focam unicamente no produto - não na experiência.

Assim, a diferenciação no marketing tradicional se baseia em propostas não relevantes para o consumidor, pois a diferenciação simplesmente é isso: ser diferente. Um restaurante que contrata malabaristas para atenderem seus clientes está se diferenciando por meio de toda uma experiência lúdica em torno de seus atendentes, diferentemente de um restaurante que se diferencia às bases do marketing tradicional, por exemplo, enfatizando sua decoração à base de madeira rústica (SCHMITT, 2004). 
Por um lado, Schmitt parece estar em concordância com outros autores do Marketing tradicional. O próprio KOTLER (2006) também diz que a orientação para clientes é mais discurso do que pratica. No entanto, é no mínimo questionável até que ponto isso é um problema do conceito de marketing ou das empresas.

Em relação à diferenciação, o autor tem razão em afirmar que os livros enfatizam demais as possibilidades de diferenciação mais objetivas, como atributos de produtos e/ou serviços. No entanto, ainda que de maneira tímida, existem conceitos que se propõe a oferecer diferentes possibilidades de diferenciação que não fiquem restritas às características do produto.

Um exemplo disto é, de maneira superficial, o conceito de diferenciação pela imagem apresentado por KOTLER e KELLER (2006).

\subsubsection{A satisfação do cliente:}

De acordo com Schmitt, o conceito de satisfação do marketing tradicional é puramente funcional, focando essencialmente o resultado da compra, onde o cliente compara o desempenho do produto com suas expectativas, ou seja, é uma análise puramente funcional.

Segundo o autor, há de se considerar todas as dimensões experienciais do consumo do produto que interessam aos clientes, como os sentimentos, associações emocionais, o relacionamento com outras pessoas, dentre outras.

Ou seja, Schmitt coloca que a perspectiva de valor para os clientes é eminentemente racional, utilitária, o que parece ser também mais um radicalismo do autor.

Para ele, sob a ótica do marketing tradicional, um consumidor se satisfaria caso maximizasse a quantidade de produtos comprados com o dinheiro disponível. Ao contrário, o marketing experiencial considera outras dimensões, como a estética do supermercado, sociabilidade junto às pessoas presentes ou emoções despertadas durante a experiência. (SCHMITT, 2004).

Este ponto também não tem muito sentido. O conceito de marketing sempre abordou a satisfação do cliente de maneira ampla. Isto pode ser visto em LEVITT (1985), quando 
desenvolve o conceito de produto ampliado, mostrando que o valor de um produto vai além dos seus aspectos básicos e funcionais.

KOTLER e KELLER (2006) também mostram a questão de valor sob outra perspectiva, ao afirmarem que o

\footnotetext{
"valor total para o cliente é o valor monetário de um conjunto de beneficios econômicos, funcionais e psicológicos que os clientes esperam de determinado produto ou serviço." (p. 140)
}

A questão de valor, dentro de uma visão mais abrangente também é abordada por ZEITHAML (1988), que entende que o valor oferecido ao cliente deve levar em conta também os critérios mais subjetivos. Segundo a autora:

"valor são todos os fatores, tanto qualitativos como quantitativos, subjetivos e objetivos, que compõem a experiência de compras completa."

Nesta definição é reconhecida explicitamente a natureza subjetiva do conceito de valor, e que está ligado à experiência de compra completa, e não apenas na visão restrita de aquisição de um produto.

\subsubsection{Gestão do relacionamento com o cliente (CRM):}

Schmitt também critica o fato dos programas de gestão do relacionamento com o cliente focarem as transações, e não a construção de relacionamentos. As organizações registram dados facilmente mensuráveis do processo, não informações menos quantificáveis que contribuem para traçar o perfil do consumidor.

Assim, a principal crítica ao CRM do marketing tradicional diz respeito à incapacidade desse processo no estabelecimento de vínculos emocionais com o consumidor, visto que não coleta dados não funcionais, nem importantes feedbacks dos clientes. 
Como alternativa à insuficiência do CRM, Schmitt propõe a GEC, gestão da experiência do consumidor. Exemplificando ambos os processos: o CRM busca informações a respeito de quantos itens foram adquiridos de determinado produto, em quanto tempo o consumidor deixa de comprar um produto, quais meios de pagamento são utilizados por um cliente, etc...

A GEC considera a interação do consumidor ao longo de cada ponto de contato, desenvolvendo mecanismos capazes de consolidar algum tipo de lealdade e agregar valor à experiência. Caso um consumidor comprasse habitualmente vinhos e queijos, o sistema da GEC poderia propor outras opções de vinhos ou até mesmo dar copos de cortesia (SCHMITT, 2004).

A crítica que Schmitt faz parece ter coerência, pois os atuais sistemas de CRM realmente enfatizam apenas as questões quantificáveis, desprezando as informações do consumidor sob a perspectiva experiencial.

Além disso, deve-se lembrar de que boa parte dos programas de fidelização cria o que pode ser chamado de "algema de ouro", ou seja, ao invés de conquistar a fidelidade, compram-na, pois os programas chamados de fidelização são, em sua maioria, programas de descontos progressivos e/ou pontos que resultam em brindes e ofertas.

\subsection{Relação entre os autores}

Como observado, em que pese vários pontos em comum entre os conceitos e teorias expostos, os autores estudados abordam o Marketing Experiencial e a experiência do consumidor de maneiras distintas entre si.

Como pioneiros, Holbrook e Hirschman exploram o conceito de experiência de maneira bastante ampla, comparando os até então predominantes modelos de análise do comportamento de compra do consumidor com a perspectiva experiencial.

Para eles, a experiência é definida como "uma ocorrência pessoal, muitas vezes com significado emocional importante, baseada na interação com os estímulos que são os produtos ou serviços consumidos." (HOLBROOK e HIRSCHMAN, 1982b) 
Um conceito semelhante é dado também por CARBONE e HAECKEL (1994), que definem experiência como sendo "a impressão formada por encontros das pessoas com produtos, serviços e empresas; uma percepção produzida quando as pessoas consolidam informações sensoriais".

PINE II E GILMORE (1999) definem experiência como sendo "eventos que envolvem indivíduos de uma maneira pessoal", e estudam a presença das experiências na economia como uma oferta econômica distinta das demais.

SCHMITT (1999) afirma que, da perspectiva do cliente, "as experiências envolvem a vida inteira das pessoas. Muitas vezes é resultado da observação direta e/ou participação em eventos, sejam eles reais, virtuais ou imaginários."

Nota-se que, ao longo da evolução do conceito, os autores mais focados nesta tese, gradativamente deixam de apresentar uma visão ampla e abrangente em relação à experiência, e caminham para uma visão mais específica e fragmentada da mesma, não apenas levando em conta a natureza e o contexto na qual elas estão presentes, mas como se caracterizam os diversos elementos e aspectos que compõem a interação ao longo da trajetória de um consumidor junto a uma organização.

Essa tentativa de fragmentar e/ou classificar as experiências é feita primeiramente por Pine II e Gilmore que, como visto, focam na relação entre o consumidor e a organização, através do cruzamento entre duas dimensões (interação entre o consumidor e o ambiente, e o tipo de participação do consumidor na experiência) para classificarem as experiências em quatro tipos: Entretenimento, Educacional, Estética e Escapista.

Já Schmitt enfatiza os fenômenos inerentes ao consumidor, dividindo as experiências em cinco diferentes tipos: sensoriais, emocionais, cognitivas, comportamentais e relacionais.

Vale observar que não são visões antagônicas, mas sim, podem ser vistas como complementares, pois apesar das diferenças existentes, é fato que existem várias semelhanças entre os conceitos apresentados na fundamentação teórica de cada autor. 
É importante destacar que as questões experienciais analisadas deixam claro a interação entre os consumidores e as organizações.

ROBINETE et al (2002) seguem no mesmo caminho ao definirem experiência como sendo "o conjunto de pontos nos quais as empresas e os consumidores trocam estímulos sensoriais, informações e emoções.” (p. 58)

A mesma interação é explícita na definição de experiência dada por SHAW e IVENS (2002): “Uma interação entre uma organização e um cliente. É uma mistura do desempenho físico de uma organização, os sentidos estimulados e emoções evocadas em todos os momentos de contato".

Para MEYER e SCHWAGER (2007), as experiências podem ser definidas como sendo:

"a resposta interna e subjetiva que os clientes tem de qualquer contato direto ou indireto com uma empresa. O contato direto geralmente ocorre durante a compra e uso do produto, e geralmente é iniciada pelo cliente. Contato indireto na maioria das vezes envolve encontros não planejados com representantes da empresa, serviços ou marcas, e assume a forma de comunicação boca-a-boca, críticas, publicidade, notícias, relatórios e comentários."

Outra definição de experiência que segue a mesma linha é dada por GENTILE et al:

"A experiência do cliente se origina a partir de um conjunto de interações entre um cliente e um produto, uma empresa, ou parte de sua organização, que provocam uma reação. Esta experiência é estritamente individual e implica o envolvimento do cliente em diferentes níveis (racional, emocional, sensorial, físico e espiritual). A avaliação depende da comparação entre as expectativas do cliente e os estímulos provenientes da interação com a empresa, a partir dos diferentes pontos de contatos."

Uma última definição é feita por ISMAIL et al (2011), para quem as experiências são “emoções provocadas, sensações sentidas, conhecimentos adquiridos e competências 
conquistadas através do envolvimento ativo com a empresa, antes, durante e após o consumo".

Além da interação entre o consumidor e empresa, outra importante característica presente nestes conceitos é a questão das emoções e escolhas subjetivas do consumidor.

A emoção está presente em todos os conceitos fundamentais até agora apresentados, e corresponde a um tema essencial para o Marketing Experiencial visto que, sem ela, as escolhas do consumidor se baseariam unicamente em aspectos racionais, lógicos, objetivos e materiais, não havendo espaço para uma diferenciação que leve em conta a subjetividade do consumidor.

Na verdade, esta questão é tão importante que pode ser vista em quase toda a bibliografia que trata do tema Marketing Experiencial. Apenas para exemplificar, Shaw (2007) defende de maneira veemente a questão da emoção como componente de uma experiência, a ponto de dedicar um livro - "The DNA of Customer Experience: How emotion drive value" basicamente para analisar a presença das emoções nas experiências.

Isso significa que os conceitos de Marketing Experiencial passam, obrigatoriamente, pelo significado amplo e profundo que o consumo passa a ter para o consumidor. Em outras palavras, deixa-se de analisar unicamente um produto ou serviço segundo seus aspectos funcionais para, ao invés disso, considerar também a experiência que o envolve.

Assim, apesar das divergências entre as abordagens propostas, um dos principais pontos de concordância entre os autores que desenvolvem trabalhos sobre o tema se situa em torno do significado e da relevância que a experiência proporciona para o consumidor ao longo dos momentos de compra e consumo.

Neste quesito, existem vários trabalhos publicados abordando a questão, além dos conceitos já discutidos. Dentre eles, CARU e COVA (2006; 2008), que mostram que a busca crescente por parte dos consumidores para vivenciar experiências variadas não é um processo imediato, mas algo que vai progredindo e se desenvolvendo ao longo do tempo, fazendo com que seja necessário dar maior atenção nos diversos pontos de contato do serviço oferecido. 
Outro trabalho que trata da questão da experiência do consumidor foi feito por BOSMANS e BAUMGARTNER (2005), em que procuram analisar o estado de humor do consumidor e a relação deste com as expectativas afetivas do consumo.

Outro ponto em comum é o fato dos autores afirmarem que as experiências afetam os consumidores de maneira única, ou seja, cada experiência é singular para um consumidor. Isso significa que dois consumidores não conseguem passar por uma mesma experiência, já que cada indivíduo apresenta traços, temperamentos e percepções diferentes.

Holbrook confirma esta opinião ao defender que as experiências são fenomenológicas, ou seja, a percepção e interpretação de um indivíduo (consumidor) em relação a um fenômeno (experiência) se limita à sua percepção (relativa a ele).

Pine II e Gilmore também contribuem nessa questão ao afirmarem que uma experiência envolve um consumidor de maneira pessoal e memorável, ou seja, a experiência tem impacto no interior do consumidor, e passa a ser inerente a ele.

Schmitt menciona em sua definição que as experiências são acontecimentos individuais, visto que os estímulos afetam diferentemente os consumidores, que respondem diferentemente a cada estímulo.

No entanto, independente dos pontos convergentes e divergentes dos conceitos acima citados, a questão experiencial merece, por parte das empresas, um cuidado especial na sua implantação. Para isso, vale o alerta de BERRY et al (2002):

"Nos últimos anos, os gestores estão cada vez mais conscientes da necessidade de criar valor para seus clientes na forma de experiências. Infelizmente, muitas vezes a gestão da experiência se resume a proporcionar entretenimento ou algo atraentemente criativo. A questão é mais complexa do que isso. Restaurantes que colocam fotos de astros do cinema em suas paredes e varejistas que penduram motocicletas em seus tetos, para dar apenas dois exemplos, ficarão desapontados com a resposta dos clientes, se estes objetos não fizerem parte de uma bem concebida e abrangente estratégia de gerenciamento da experiência do cliente." 
As ações experienciais não devem ser fortuitas, eventuais, e sem um conceito que faça parte da estratégia da empresa. Ao contrário, devem ser coerentes, dar consistência às ideias desenvolvidas, e serem integradas ao posicionamento pretendido pela organização.

Além dos pontos em comum já citados, existem outros dois que são o objeto maior desta pesquisa e, por isso mesmo, merecem uma análise mais detalhada, como será visto a seguir.

\subsubsection{A questão sensorial}

A maior parte dos conceitos estudados mostra que a experiência do consumidor passa necessariamente pelos seus sentidos. Holbrook, por exemplo, destaca que um dos principais critérios na decisão de compra é a estética que determinado produto ou serviço apresenta.

Pine II e Gilmore não apenas criam um domínio específico para abordar esse ponto, o domínio Estético, como afirmam que o envolvimento dos cinco sentidos é um dos passos fundamentais para o Marketing Experiencial.

Schmitt também expressa sua visão a respeito dos sentidos. Um de seus modelos experienciais mais relevantes é o modelo sensorial, fortemente analisado no seu livro "A Estética do Marketing" (1997), onde alega que o consumo e as experiências são essencialmente sensoriais.

Este é um ponto de destaque nesta tese. O uso dos sentidos no marketing vem sendo discutido há um bom tempo.

Um dos primeiros trabalhos sobre isso foi escrito por KOTLER (1973-1974), onde ele define "atmosfera de loja" como sendo as qualidades sensoriais dos pontos de venda projetadas para evocar respostas específicas nos consumidores, criando um ambiente que produz efeitos emocionais no indivíduo, a fim de aumentar a sua probabilidade de compra.

ZEITHAML e BITNER (2003) também analisam este ponto, mostrando que as características físicas dos ambientes tem influência no consumidor, que reage de modo cognitivo, emocional e psicológico ao seu entorno físico, de maneira única e interdependente. 
TURLEY e CHEBAT (2002) mostram que mesmo pequenas mudanças nos estímulos ambientais que não são conscientemente percebidas pelo consumidor, são capazes de mudar comportamentos dentro de uma loja.

O trabalho de DONOVAN et al (1994) também analisa a atmosfera de compra, mostrando que os consumidores tendem a gastar mais tempo e mais dinheiro em ambientes agradáveis. Outro estudo interessante sobre atmosfera de compra foi feito por KALTCHEVA e WEITZ (2006), e mostra que os estímulos ambientais que ajudam o consumidor a atingir seus objetivos são percebidos como agradáveis, enquanto os estímulos que impedem a realização de um objetivo são avaliados como desagradáveis.

Pode-se dar como exemplo a música ambiente. Numa sala de espera pode ser agradável na medida em que ajuda o tempo a passar. No entanto, a mesma música pode ser vista como desagradável numa biblioteca, se isto atrapalhar a leitura e concentração das pessoas.

O ambiente de compra é tão importante que afeta a percepção que os clientes tem da qualidade do serviço, dos produtos e até mesmo, ainda que em menor escala, do preço praticado, conforme indica o trabalho de PARASURAMAN (2002).

Como esta tese desenvolveu uma pesquisa de campo realizada em hotéis, é importante também citar o estudo de BITNER (1992) que mostra que a capacidade do ambiente físico para influenciar comportamentos e criar imagem é particularmente evidente para as empresas de serviços, como hotéis, restaurantes, escritórios profissionais, bancos, lojas de varejo e hospitais.

Além de todos estes estudos mais amplos sobre o ambiente de compra, muitos outros tem sido feitos para estudar especificamente cada um dos sentidos e sua influência ou relação com as situações de consumo.

KELLARIS et al (2007), por exemplo, estudaram a percepção de música e tempo em diferentes contextos de marketing.

O sentido da audição também foi pesquisado por IKEDA et al (2005), que mostrou que "a experiência proporcionada por eventos musicais em shopping pode beneficiar o 
estabelecimento em termos de maior simpatia e satisfação do público, melhoria de imagem, atração de novos consumidores, aumento do fluxo de visitantes e do volume de vendas".

Bem antes do estudo citado acima por Kaltcheva e Weitz, MILLIMAN, R. E. (1982) mostrava que é possível influenciar o comportamento com a música, mas essa influência pode contribuir para o processo de alcançar objetivos ou interferir com ele. Assim, a música escolhida deve ser coerente e combinar com os objetivos pretendidos pela empresa.

A influência do sentido da audição no ambiente de compra e comportamento do consumidor também pode ser estudado nos trabalhos de DUBÉ et al (1995), HERRINGTON e CAPELLA (1994), e GREWAL et al (2003).

Outro sentido que também merece atenção é o olfato. O trabalho de BOSMANS (2006) analisa a questão dos perfumes e sua relação com a avaliação dos produtos.

FIORE et al (2000) mostram a importância de se combinar o display de um produto com o aroma do ambiente, ressaltando o cuidado que se deve ter na seleção e aplicação das fragrâncias.

Para MILOTIC (2003), as empresas devem considerar um pouco mais as pesquisas sensoriais para competir efetivamente no mercado e, por isso, o uso das fragrâncias não deve ficar restrito às perfumarias, e nem deve ser um mistério para os empresários, já que o sentido do olfato desempenha um papel importante na decisão de compra de muitos produtos.

A mesma opinião é compartilhada por MITCHELL (1994), que afirma que o uso dos aromas nos ambientes não serve apenas para se comunicar informações sobre atributos do produto, mas também para proporcionar uma atmosfera de consumo com a intenção de influenciar os consumidores.

GULAS e BLOCK (1995) também mostram que a aromatização de ambientes não apenas influenciam as respostas afetivas do consumidor. 
Outros sentidos também receberam atenção, como é o caso da questão visual, pesquisado por BONE e FRANCE (2001) que mostram que as representações gráficas tem um efeito significativo e de longo prazo sobre as crenças e intenções de compra dos produtos.

BRENGMAN e GEUENS (2004) analisam a questão da visão, pesquisando o impacto das cores nas emoções do consumidor. KRISHNA (2006) também mostra a importância dos sentidos, destacando a questão visual e tátil.

Concluindo, a configuração de um espaço para a experiência pressupõe a criação de uma atmosfera coerente com os conceitos a serem trabalhados. Para isso, é fundamental que os elementos sensoriais inseridos nesse ambiente contribuam para efetivamente criar e consolidar uma determinada atmosfera, aumentando sua atratividade, reforçando vínculos existentes ou permitindo o estabelecimento de novos vínculos entre a empresa e seus consumidores.

Como esta tese analisa a questão experiencial no segmento hoteleiro, é importante também destacar que a questão da experiência do cliente como um todo, e os aspectos sensoriais de maneira mais específica, tem grande importância nesta área.

SPERDIN e PETERS (2009) mostram que a qualidade da experiência deve ser o ponto de partida para se avaliar as emoções da indústria do turismo, e que estas são influenciadas fortemente pelo ambiente.

O mesmo raciocínio é partilhado por MOSSBERG (2007), que afirma que "os turistas serão influenciados pelo ambiente físico, e perceberão sinais visuais, cores, sons, artefatos, etc...”.

A mesma conclusão é encontrada num estudo de HEMMINGTON (2007), que tem como base os conceitos de Pine II e Gilmore, e que defende que os hotéis devem se concentrar na experiência memorável dos hóspedes, através de ações que estimulem os cinco sentidos.

Finalmente nesta mesma linha, WALLS (2011) mostra que as experiências dos hóspedes de um hotel de luxo são criadas fundamentalmente pelo ambiente físico e pela interação humana. 


\subsubsection{Pontos de contato}

Além da questão sensorial, os conceitos estudados deixam claro que a experiência do consumidor é proporcionada pelos pontos de contato. Como mostrado por GREWAL et al (2009), a experiência do cliente inclui todos os pontos de contato na qual o cliente interage com o negócio, produto ou serviço.

Como discutido anteriormente, o conceito de proexps criado por Schmitt, pode ser perfeitamente identificado como Pontos de Contato. Vale ressaltar que o conceito de proexps procura englobar todos os bens comercializados e, por isso mesmo, tem um raio de abrangência muito grande.

Essa abrangência serve para conceituar a ideia de Schmitt. No entanto, num estudo de caso, é mais razoável adaptar esses proexps para a realidade do objeto investigado.

Sendo assim, foi usado nesta tese o conceito de Pontos de Contato. Para isso, a partir dos conceitos desenvolvidos por KUAZAKI (2000), CASTELLI (1991), BALANZÁ e NADAL (2003) e KOTLER et al (1997), foram definidos que os principais pontos de contato a serem analisados nos hotéis seriam:

- Apartamentos

- Bares e Restaurantes

- Centro de Convenções

- Áreas de lazer / esporte

- Comunicação (incluindo as formas de propaganda, promoção, marketing direto, website, etc.)

- Pessoas (funcionários do hotel)

- Áreas comuns (lobby, hall, áreas livres, etc..)

Como o objetivo desta tese é analisar o uso das experiências sensoriais como ferramenta de marketing nos hotéis, as ações que atingem os sentidos humanos serão cruzadas com os pontos de contato listados acima. 
Antes do próximo capítulo, existem dois pontos fundamentais para serem colocados como a visão de tudo o que foi estudado até agora.

Em primeiro lugar, pode-se concluir que o conceito de Marketing Experiencial não é diferente, e muito menos antagônico àquilo que Schmitt chama de marketing tradicional. Ao contrário, o Marketing Experiencial é um desenvolvimento do conceito de marketing que, como ciência, é passível de desenvolvimento constante.

Nem sempre em marketing, ou em qualquer outra ciência, o desenvolvimento de um novo ponto de vista, uma nova descoberta ou uma nova técnica, necessariamente deve contestar e criticar tudo o que já havia sido criado, desenvolvido, aprendido e testado. Portanto, a ideia de que o Marketing Experiencial se contrapõe aos conceitos clássicos de marketing é fortemente refutada nesta tese.

Com isso, chega-se ao segundo ponto. Apesar do termo Marketing Experiencial ser usado diversas vezes, pois este é o termo usado em quase toda a bibliografia, é fundamental esclarecer que, nesta tese, Marketing Experiencial refere-se ao uso das experiências sensoriais no marketing.

E este é o desenvolvimento citado acima, ou seja, a contribuição de todos estes autores não está em criar "um novo marketing", mas sim, o de mostrar como as experiências sensoriais, nas suas diferentes abordagens, podem e devem ser usadas nas ações de marketing.

É exatamente com base nisto que a pesquisa será desenvolvida: será analisado o uso das experiências sensoriais nos diversos pontos de contato de hotéis 5 estrelas, como será explicado no próximo capítulo. 


\section{PESQUISA DE CAMPO}

O objetivo deste item é descrever a opção metodológica adotada para o desenvolvimento da tese. Para isso, cabe explicar os seguintes pontos: os objetivos da pesquisa, a opção metodológica escolhida, o setor a ser pesquisado e o protocolo do trabalho de campo.

\subsection{Objetivo geral do trabalho de campo}

Para alcançar os resultados esperados nesta tese, já explicados na introdução deste projeto, foi definido que o objetivo específico do trabalho de campo seria:

Identificar e descrever o uso das experiências sensoriais nas ações de marketing desenvolvidas em hotéis 5 estrelas da cidade de São Paulo.

\subsection{Metodologia do trabalho de campo}

O tipo de pesquisa escolhido depende, fundamentalmente, do objetivo do estudo. Foi desenvolvido um Estudo Exploratório que, segundo SELLITZ (1974), deve ser usado quando se pretende obter familiarização ou nova compreensão de um fenômeno, o que exige planejamento de pesquisa suficientemente flexível para permitir avaliação de seus múltiplos aspectos.

MALHOTRA (2001) também mostra que a pesquisa exploratória é a mais adequada quando o objetivo é a maior compreensão do problema, ou seja, quando assuntos ainda pouco estabelecidos são estudados. $\mathrm{O}$ autor coloca que, para isso, a pesquisa exploratória tem como característica o fato de ser mais flexível e versátil em termos de métodos de coleta de dados, que se utiliza, além da análise de dados secundários, de entrevistas com especialistas, estudos de caso, focus group, dentre outros.

Por isso, como o tema desta pesquisa é Marketing Experiencial e, como visto, é um assunto ainda pouco estudado no mundo inteiro e, em especial, no Brasil, optou-se por uma pesquisa exploratória. 
Também é importante destacar que este estudo terá caráter qualitativo, ou seja, é uma metodologia de pesquisa não-estruturada, exploratória, que proporciona reflexões e compreensão do contexto do problema. As informações podem ser obtidas a partir da análise do discurso dos entrevistados, considerando-se também a postura frente às questões que são colocadas. A pesquisa qualitativa não tem preocupação estatística, ou seja, é um método bastante adequado quando se quer explorar um problema. Consequentemente, os dados podem ser considerados conclusivos, mas não podem ser utilizados para se fazer generalizações em relação à população. (MALHOTRA, 2001)

Finalmente, como o objetivo desta tese é identificar e descrever o uso das experiências sensoriais nas ações de marketing em hotéis da cidade de São Paulo, a pesquisa foi desenvolvida através do método estudo de caso.

\subsection{O método estudo de caso}

Para a realização desta pesquisa, foi escolhido o método do estudo de caso por ser este o mais adequado para se compreender melhor o problema proposto para a pesquisa de campo.

Segundo Yin:

"Os estudos de caso são o método preferido quando: a) as questões "como” $e$ "por que" são propostas; b) o investigador tem pouco controle sobre os eventos; c) o enfoque está sobre um fenômeno contemporâneo no contexto da vida real." (YIN, 2010, p. 22)

Esta visão também é defendida por Campomar, que afirma que:

"O estudo intensivo de um caso permite a descoberta de relações que não seriam encontradas de outra forma, sendo as análises e inferências em estudo de casos feitas por analogia de situações, respondendo principalmente às questões como e porquê." (CAMPOMAR, 1991, p. 96/97) 
Neste estudo, o objetivo é analisar se o uso ou não das experiências sensoriais é feito em hotéis 5 estrelas da cidade de São Paulo.

Para isso, foi utilizado o estudo de casos múltiplos que, segundo YIN (2010) é justificado pelo entendimento das replicações literais e teóricas, nos quais se faz um levantamento de dados semelhantes e a análise dos resultados é apresentada em conjunto.

Vale ressaltar, como aponta CAMPOMAR (1991), que o estudo de caso é um método de pesquisa social empírico, que envolve a análise intensiva de um número relativamente pequeno de situações. Sendo um método qualitativo, as inferências feitas a partir dos resultados obtidos não são estatísticas.

No estudo de caso, segundo GODOY (1995, p. 26) o pesquisador geralmente utiliza uma variedade de dados coletados em diferentes momentos, por meio de diversas fontes de informação. Os dados devem ser coletados no local onde os eventos e fenômenos acontecem, incluindo entrevistas, observações e análise de documentos.

YIN (2010, p.129) apresenta as fontes de evidências mais comuns utilizadas na etapa de coleta de dados de um estudo de caso, ressaltando seus pontos fortes e fracos. O Quadro 1 apresenta estas fontes: 
Quadro 1 - Seis fontes de evidências: pontos fortes e fracos

\begin{tabular}{|c|c|c|}
\hline $\begin{array}{l}\text { Fontes de } \\
\text { evidências }\end{array}$ & Pontos fortes & Pontos fracos \\
\hline Documentação & $\begin{array}{l}\text { - Estável - pode ser revista } \\
\text { repetidamente } \\
\text { - Discreta - não foi criada em } \\
\text { consequência do estudo de caso } \\
\text { - Exata - contém nomes, } \\
\text { referências e detalhes exatos de } \\
\text { um evento } \\
\text { - Ampla cobertura - longo } \\
\text { período de tempo, muitos eventos } \\
\text { e muitos ambientes }\end{array}$ & $\begin{array}{l}\text { - Recuperabilidade - pode ser difícil } \\
\text { de encontrar } \\
\text { - Seletividade parcial, se a coleção } \\
\text { for incompleta } \\
\text { - Parcialidade do relatório - reflete } \\
\text { parcialidade (desconhecida) do autor } \\
\text { - Acesso - pode ser negado } \\
\text { deliberadamente }\end{array}$ \\
\hline $\begin{array}{l}\text { Registros de } \\
\text { arquivos }\end{array}$ & $\begin{array}{l}\text { - (idem à documentação) } \\
\text { - Precisos e geralmente } \\
\text { quantitativos }\end{array}$ & $\begin{array}{l}\text { - (idem à documentação) } \\
\text { - Acessibilidade devido a razões de } \\
\text { privacidade }\end{array}$ \\
\hline Entrevistas & $\begin{array}{l}\text { - Direcionadas - focam } \\
\text { diretamente os tópicos do estudo } \\
\text { de caso } \\
\text { - Perceptíveis - fornecem } \\
\text { inferências e explanações causais } \\
\text { percebidas }\end{array}$ & $\begin{array}{l}\text { - Parcialidade devido às questões } \\
\text { mal articuladas } \\
\text { - Parcialidade da resposta } \\
\text { - Incorreções devido à falta de } \\
\text { memória } \\
\text { - Reflexividade - o entrevistado dá } \\
\text { ao entrevistador o que ele quer ouvir }\end{array}$ \\
\hline $\begin{array}{c}\text { Observações } \\
\text { diretas }\end{array}$ & $\begin{array}{l}\text { - Realidade - cobre eventos em } \\
\text { tempo real } \\
\text { - Contextual - cobre o contexto } \\
\text { do "caso" }\end{array}$ & $\begin{array}{l}\text { - Consome tempo } \\
\text { - Seletividade - ampla cobertura é } \\
\text { difícil sem uma equipe de } \\
\text { observadores } \\
\text { - Reflexividade - evento pode } \\
\text { prosseguir diferentemente porque } \\
\text { está sendo observado } \\
\text { - Custo - horas necessárias pelos } \\
\text { observadores humanos }\end{array}$ \\
\hline $\begin{array}{c}\text { Observações } \\
\text { do participante }\end{array}$ & $\begin{array}{l}\text { - (idem aos acima para } \\
\text { observações diretas) } \\
\text { - Discernível ao comportamento e } \\
\text { aos motivos interpessoais }\end{array}$ & $\begin{array}{l}\text { - (idem aos acima para observações } \\
\text { diretas) } \\
\text { - Parcialidade devido à manipulação } \\
\text { dos eventos pelos observadores } \\
\text { humanos }\end{array}$ \\
\hline $\begin{array}{l}\text { Artefatos } \\
\text { físicos }\end{array}$ & $\begin{array}{l}\text { - Discernível às características } \\
\text { pessoais } \\
\text { - Discernível às operações } \\
\text { técnicas }\end{array}$ & $\begin{array}{l}\text { - Seletividade } \\
\text { - Disponibilidade }\end{array}$ \\
\hline
\end{tabular}

Fonte: YIN, 2010, p.129 
Para este estudo, foi proposto que a coleta de dados fosse feita a partir da utilização de quatro fontes de evidência:

a) Documentação: análise do material de comunicação de marketing, como broadsides, folders, folhetos, sites e anúncios.

b) Registros de arquivos: serão analisados os registros contendo resultados dos hotéis: taxa de ocupação, avaliação dos hóspedes, e apresentações e gráficos contendo resultados alcançados.

c) Entrevistas: estas serão a base desta tese. Serão feitas com executivos da área de marketing e/ou direção geral dos hotéis pesquisados, seguindo roteiros semiestruturados, conforme demonstrado no protocolo (Apêndice A).

d) Observações diretas: serão feitas pelo pesquisador, que visitará as instalações dos hotéis, acompanhado dos entrevistados e/ou de algum funcionário indicado por estes.

\subsection{Escolha do setor econômico}

A proposta para esta tese é realizar o trabalho de campo em hotéis de categoria 5 estrelas localizados na cidade de São Paulo. Os motivos para isto são:

a) a importância que o turismo, de modo amplo, e consequentemente a hotelaria, de maneira mais específica, tem para a economia.

b) a matriz da indústria hoteleira brasileira, como será visto a seguir, indica que os hotéis de categoria superior tendem a ter uma estrutura administrativa maior, seja por fazerem parte de grandes grupos, e/ou pela exigência do próprio porte do hotel, geralmente maior pelas suas características.

c) A escolha da cidade de São Paulo se justifica não apenas pela facilidade de acesso aos dados, visto que é a cidade de residência do autor da tese, como também pela importância que a cidade tem no turismo nacional, como será visto nos próximos itens. 
Para isso, é importante apresentar alguns dados e conceitos referentes ao setor turístico e, na sequência, fornecer um panorama do turismo e da hotelaria em São Paulo.

\subsubsection{Turismo mundial e a realidade brasileira}

É difícil encontrar uma definição única do que seja Turismo. Segundo a UNWTO (World Tourism Organization), órgão da ONU, turismo pode ser definido como sendo "as atividades que as pessoas realizam durante suas viagens e permanência em lugares distintos dos que vivem, por um período de tempo inferior a um ano consecutivo, com fins de lazer, negócios e outros." (UNWTO, 2011)

Para MOTA (2001, p. 43), “Turismo é um fenômeno social que consiste no deslocamento temporário e voluntário de um ou mais indivíduos que, por uma complexidade de fatores que envolvem a motivação humana, saem de seu local de residência habitual para outro, no qual não exercem atividades lucrativas ou remuneradas, gerando múltiplas inter-relações de importância cultural, socioeconômica e ecológica entre os núcleos emissores e receptores.”

As definições acima mostram que existem algumas pequenas diferenças entre elas, mas nada que se possa ser considerado antagônico. Independente de uma definição única e definitiva, que para este trabalho não parece ser fundamental, o fato é que o turismo tem experimentado ao longo das últimas décadas um crescimento contínuo, consistente e diversificado, sendo um dos setores econômicos que mais cresce no mundo.

Segundo CASTELLI (1991, p. 14/15), "vários são os fatores que contribuíram para o incremento das viagens turísticas: maior liberação do tempo, aumento da renda familiar, progresso tecnológico, melhoria do nível de instrução e concentração urbana”.

Este crescimento pode ser comprovado pelos dados da Tabela 3, que mostra um crescimento significativo e sólido na chegada de turistas internacionais nas últimas décadas. 


\section{Tabela 3 - Evolução da chegada de turistas internacionais}

\begin{tabular}{|l|l|}
\hline Ano & \multicolumn{1}{|c|}{ Turistas } \\
\hline 1950 & 25 milhões \\
\hline 1980 & 277 milhões \\
\hline 1990 & 435 milhões \\
\hline 2000 & 675 milhões \\
\hline 2010 & 940 milhões \\
\hline
\end{tabular}

Fonte: UNWTO, 2011

Este crescimento mostra que efetivamente as atividades turísticas estão cada vez mais fortemente ligadas ao desenvolvimento e ao progresso socioeconômico dos locais de destinos.

O volume de negócios proporcionado pelo turismo pode ser comparado à indústria do petróleo, de produtos alimentícios e de automóveis, para citar apenas três setores de fundamental importância para a economia mundial. Exatamente por isso, o turismo acaba por representar uma das principais fontes de renda para muitos países, inclusive os que estão em processo de desenvolvimento.

Segundo a UNWTO (2011), em 2010, as receitas geradas apenas pelo turismo internacional foram de US\$ 1,1 trilhão, o que significa um aumento real de 4,7\% em relação a 2009. Esse valor foi obtido com as 940 milhões de chegadas de passageiros internacionais, visto acima, e que é um dos indicadores do setor. Esses números fazem com que o turismo represente, em termos mundiais, cerca de $7 \%$ dos empregos diretos e indiretos, e 5\% do PIB.

A UNWTO (2011) também mostra os motivos das viagens internacionais: 51\%, ou seja, cerca de 480 milhões de chegadas foram para lazer, recreio e férias. Por volta de $15 \%$ dos turistas internacionais viajaram por motivos comerciais e profissionais, e $27 \%$ viajaram por outros motivos: visitar amigos e parentes, razões religiosas e romarias, tratamento de saúde, etc...

A tabela 4 mostra o ranking dos países que mais receberam turistas internacionais, e também os que tiveram maior receita com estes turistas, no ano de 2010: 
Tabela 4 - Ranking de chegadas e receitas com turistas internacionais

\begin{tabular}{|c|l|l|}
\hline Pos. & Qtde. & \multicolumn{1}{|c|}{ Receita } \\
\hline 1 & França & EUA \\
\hline 2 & EUA & Espanha \\
\hline 3 & China & França \\
\hline 4 & Espanha & China \\
\hline 5 & Itália & Itália \\
\hline 6 & Reino Unido & Alemanha \\
\hline 7 & Turquia & Reino Unido \\
\hline 8 & Austrália & Austrália \\
\hline 9 & Malásia & Hong Kong \\
\hline 10 & México & Turquia \\
\hline
\end{tabular}

Fonte: UNWTO, 2011

Como demonstrado na tabela acima, 40\% dos países que mais recebem turistas estão localizados na Europa. Isto reforça os dados da UNWTO (2011), sobre a participação das regiões no total de chegadas internacionais, conforme tabela 5:

Tabela 5 - Chegada de turistas internacionais por região - 2010

\begin{tabular}{|l|c|}
\hline \multicolumn{1}{|c|}{ Continente } & $\mathbf{\%}$ \\
\hline Europa & $56 \%$ \\
\hline Ásia e Pacífico & $21 \%$ \\
\hline Américas & $16 \%$ \\
\hline Oriente Médio & $4 \%$ \\
\hline África & $3 \%$ \\
\hline
\end{tabular}

Fonte: UNWTO, 2011

O mesmo relatório da UNWTO mostra que, se analisados apenas os resultados das Américas, conclui-se que a chegada de turistas internacionais aumentou 6\% em relação a 2009, alcançando 150 milhões de turistas. Isto significou uma receita de US\$ 182 bilhões para todo o continente. Os principais destinos foram EUA, México e Canadá. 
Analisando especificamente o mercado da América Latina e Caribe (ALC), KOTLER et al (2006, p.253) mostra que existem várias tendências relacionadas ao turismo nesta região que merecem ser lembradas:

a) Planos de desenvolvimento econômico das cidades enfatizarão cada vez mais a contribuição do setor turístico.

b) Maior segmentação de mercado resultará em melhores informações de marketing e, por isso, a gestão do turismo merecerá maior ênfase.

c) Visitantes aliarão viagens de negócios às pessoais com mais frequência, enfatizando atividades culturais e de recreação, exigindo que as cidades se adaptem a isso.

d) Maior interesse em certos esportes e na recreação exigirá que as cidades invistam mais em instalações de recreação a céu aberto e criem experiências mais sensíveis ao ambiente.

e) Maior estabilidade política na ALC gerará maior confiança e, como resultado, aumento nos negócios e no turismo.

f) Jornadas de trabalho mais curtas na ALC aumentarão o turismo de finais de semana prolongados.

Kotler tem uma postura otimista com relação ao potencial de desenvolvimento turístico na ALC. Este otimismo pode também ser comprovado pelos estudos da UNWTO. No estudo intitulado UNWTO Tourism Highlights, edition 2011 (2011, p. 11), a previsão é que as chegadas internacionais deverão atingir 1,6 bilhões em 2020, o que significa um aumento de $70 \%$ nos próximos 10 anos.

Este mesmo estudo mostra que as chegadas internacionais nas Américas, em 2020, serão de 282 milhões, o que representa um aumento de $88 \%$, ou seja, a previsão é que o crescimento do turismo nas Américas será maior que a média mundial que, por si só, já é bastante significativa. 
Estes números poderiam indicar que o otimismo com o futuro deste mercado também deveria ser aproveitado pelo Brasil. No entanto, a situação brasileira não parece ser tão animadora como em outras localidades. A evolução da chegada de turistas internacionais no Brasil pode ser vista na tabela 6 :

Tabela 6 - Evolução das chegadas de turistas internacionais no Brasil

\begin{tabular}{|c|c|}
\hline Ano & Turistas \\
\hline 1994 & 1.853 .301 \\
\hline 1995 & 1.991 .416 \\
\hline 1996 & 2.665 .508 \\
\hline 1997 & 2.849 .750 \\
\hline 1998 & 4.818 .084 \\
\hline 1999 & 5.107 .169 \\
\hline 2000 & 5.313 .463 \\
\hline 2001 & 4.772 .575 \\
\hline 2002 & 3.784 .898 \\
\hline 2003 & 4.132 .847 \\
\hline 2004 & 4.793 .703 \\
\hline 2005 & 5.358 .170 \\
\hline 2006 & 5.017 .251 \\
\hline 2007 & 5.025 .834 \\
\hline 2008 & 5.050 .099 \\
\hline 2009 & 4.802 .217 \\
\hline 2010 & 5.161 .379 \\
\hline & \\
\hline
\end{tabular}

Fonte: MINISTÉRIO DO TURISMO, 2011

Como visto, apesar do Brasil ter conseguido um aumento de cerca de 7,5\% na chegada de turistas internacionais no ano de 2010, ainda estamos abaixo do resultado que conseguimos no ano 2000, ou seja, na última década o nosso turismo internacional praticamente não teve nenhuma evolução.

Este resultado, evidentemente tem um impacto direto na nossa economia. Segundo o Ministério do Turismo (2011), a conta turismo do Brasil apresentou, em 2010, uma receita de 
US\$ 5.919 milhões, contra uma despesa de US\$ 16.422 milhões. Isso significa um déficit de US\$ 10.503 milhões.

Estes resultados não podem ser considerados uma surpresa. Já em 1991, LAGE e MILONE afirmavam que "se os países subdesenvolvidos, e particularmente o Brasil quiserem abocanhar uma fatia maior deste mercado, terão, necessariamente, que arcar com pesados investimentos para desenvolver uma infraestrutura adequada, de forma a disputar de maneira mais competitiva o mercado internacional.” (1991 - p. 68)

No mesmo ano, RUSCHMANN concluía um estudo classificando a atitude mercadológica dos agentes e operadores de viagem como "empírica e assistemática, surpreendente, lamentável e inadmissível para um empresário moderno." (1991, p.99). É uma crítica bastante dura que, no entanto, parece não ter produzido grandes alterações.

Uma década depois, KUAZAQUI, também alertava que "o Brasil é uma das maiores economias do mundo, porém ocorreram poucas transformações positivas relativas a uma mudança na filosofia empresarial de negócios que pudessem conduzir a Nação a um crescimento em participação na área de serviços em base competitiva...” (2000, p.5)

No mesmo livro o autor afirma que "o Brasil não possui uma filosofia forte voltada para o turismo, tampouco para o setor hoteleiro, conforme resultados da pesquisa efetuada em centenas de empresas brasileiras dos dois setores." (2000, p.51)

As críticas feitas são comprovadas pela performance brasileira na área de turismo. De acordo com o Documento Referencial Turismo no Brasil 2011/2014 (2011, p. 28), no Ranking Global de Competitividade no Setor de Viagens e Turismo, o Brasil ocupa o $45^{\circ}$ lugar. Esta posição claramente não é condizente com o potencial da nossa economia e, muito menos, para um país que sediará dois importantes eventos nos próximos anos, como a Copa do Mundo em 2014 e os Jogos Olímpicos de 2016.

De qualquer forma, como visto em alguns dos dados apresentados, o turismo é uma indústria forte, consistente, e com crescimento constante em termos globais. Parece fácil perceber, conforme as definições dadas acima sobre turismo, que esta é uma atividade absolutamente vinculada à indústria de transporte, já que, por definição, turismo subentende deslocamento, e 
também à rede hoteleira, na medida em que o turismo pressupõe a permanência num local diferente daquele de residência habitual - ou seja, num meio de hospedagem ou alojamento.

De acordo com MOTA (2001 - p. 43), "a hotelaria pode ser compreendida como uma das principais atividades do turismo, já que atende a uma necessidade básica para sua realização, quando viabiliza a permanência do turista no local visitado por meio da hospedagem”.

Na questão hoteleira, os dados da Associação Brasileira da Indústria Hoteleira (ABIH) (2011) mostram que a oferta hoteleira no Brasil, cadastrada no Ministério do Turismo, segundo Grandes Regiões e Unidades da Federação, exibia em 31/01/2011 os seguintes números:

- Meios Hospedagem

- Unidades Habitacionais

- Leitos
5.925

275.682

662.368

Este mesmo estudo indica que $73,2 \%$ dos meios de hospedagem no país possuem até 50 Unidades Habitacionais (UHs), representando 36,8\% de leitos. Ou seja, pode-se afirmar que a matriz da indústria hoteleira no Brasil ainda é formada basicamente por empreendimentos de pequeno porte.

\subsubsection{Turismo e hotelaria em São Paulo}

A força econômica de São Paulo também se faz presente na questão turística. O Ministério do Turismo (2011) mostra que, de todos os passageiros de voos internacionais que desembarcaram no Brasil em 2010, 66\% chegou por um dos aeroportos do Estado.

Especificamente em relação à cidade de São Paulo, os dados do turismo também são expressivos: de acordo com a SPTURIS (São Paulo Turismo S/A) (2011), que é a empresa responsável pelo turismo e pelos eventos de São Paulo, a cidade recebeu 11,7 milhões de visitantes em 2010. Destes, 10,1 milhões de turistas nacionais e 1,6 milhão de estrangeiros. Estes turistas geram um movimento na cidade de R\$ 9,6 bilhões ao ano em viagens, hospedagem e transportes terrestres e aéreos. A permanência média destes turistas foi de 5,6 dias para os estrangeiros, e 3,6 dias para os brasileiros. 
A tabela 7 faz um comparativo entre os turistas que visitam a cidade de São Paulo:

Tabela 7 - Comparativo de turistas em São Paulo

\begin{tabular}{|c|c|c|}
\hline & Turistas domésticos & Turistas internacionais \\
\hline $\begin{array}{l}\text { Diária hoteleira } \\
\text { - Luxo } \\
\text { - Midscale } \\
\text { - Econômico }\end{array}$ & $\begin{array}{l}\text { - } \mathrm{R} \$ 480,11 \\
\text { - } \mathrm{R} \$ 387,07 \\
\text { - } \mathrm{R} \$ 120,38\end{array}$ & $\begin{array}{l}\text { - } \mathrm{R} \$ 775,23 \\
\text { - } \mathrm{R} \$ 550,37 \\
\text { - } \mathrm{R} \$ 380,18\end{array}$ \\
\hline Estadia média & - 3,6 dias & - 5,6 dias \\
\hline Gastos totais & - Entre R\$ 1.600 e $\mathrm{R} \$ 3.500$ & - Entre $\mathrm{R} \$ 2.000$ e $\mathrm{R} \$ 5.000$ \\
\hline Principais emissores & $\begin{array}{l}\text { - Rio de Janeiro } \\
\text { - Curitiba } \\
\text { - Belo Horizonte } \\
\text { - Brasília } \\
\text { - Porto Alegre }\end{array}$ & $\begin{array}{l}\text { - EUA } \\
\text { - Argentina } \\
\text { - Espanha } \\
\text { - Itália }\end{array}$ \\
\hline
\end{tabular}

Fonte: SPTURIS, 2011

Em que pese as diferenças apontadas na tabela acima, e que são absolutamente esperadas, o que realmente chama a atenção nos dados da SPTuris é que, ao contrário do que foi visto nos dados mundiais, São Paulo ainda é uma cidade que depende mais do turismo de negócios: $56,1 \%$ dos turistas vêm para nossa cidade por motivos profissionais; $22,4 \%$ para participar de eventos; $10,9 \%$ a lazer; $4,0 \%$ para estudos; $2,6 \%$ para visitar parentes e amigos e $2,5 \%$ para assuntos relacionados a saúde.

Ou seja, o turismo de negócios e eventos não pode ser desprezado e, nesse sentido, São Paulo tem uma força significativa. Alguns dados comprovam isso:

- São Paulo é a capital sul-americana de feiras de negócios, e está entre os top 15 destinos para eventos internacionais no mundo $\left(12^{\circ}\right.$ lugar $)$

- A cidade realiza 90 mil eventos por ano (1 evento a cada 6 minutos)

- São Paulo tem 75\% do mercado brasileiro de feiras de negócios, e 120 das 176 grandes feiras do Brasil são feitas na cidade, o que significa uma grande feira de negócios a cada 3 dias

- A receita com eventos é de $\mathrm{R} \$ 2,9$ bilhões ao ano, além de $\mathrm{R} \$ 700$ milhões em locação de área para exposição, R 700 milhões em serviços, $\mathrm{R}$ \$ 8,5 bilhões em viagens, hospedagem e transporte terrestre e aéreo e compras. 
- Esse mercado gera cerca de 500 mil empregos diretos e indiretos, e movimenta 35 mil empresas expositoras

- Circulam pelos eventos da cidade cerca de 4,3 milhões de pessoas, entre profissionais e compradores, sendo 45 mil compradores estrangeiros.

A tabela 8 mostra o resultado das últimas edições dos principais eventos realizados na cidade de São Paulo:

Tabela 8: Eventos em São Paulo

\begin{tabular}{|r|l|c|c|c|}
\hline Pos. & Evento & Público total & Turistas & Receita turística \\
\hline 1 & Virada Cultural & 4 milhões & 328 mil & $\mathrm{R} \$ 142$ milhões \\
\hline 2 & Parada GLBT & 3 milhões & 403 mil & $\mathrm{R} \$ 188$ milhões \\
\hline 3 & Réveillon na Paulista & 2,4 milhões & $100 \mathrm{mil}$ & $\mathrm{R} \$ 50$ milhões \\
\hline 4 & Bienal do Livro & $740 \mathrm{mil}$ & $290 \mathrm{mil}$ & $\mathrm{R} \$ 91$ milhões \\
\hline 5 & Salão do Automóvel & $610 \mathrm{mil}$ & $200 \mathrm{mil}$ & $\mathrm{R} \$ 112$ milhões \\
\hline 6 & Bienal Internacional de Arte & $535 \mathrm{mil}$ & $107 \mathrm{mil}$ & $\mathrm{R} \$ 120$ milhões \\
\hline 7 & Salão Duas Rodas & $240 \mathrm{mil}$ & $40 \mathrm{mil}$ & $\mathrm{R} \$ 60$ milhões \\
\hline 8 & Mostra Intern. de Cinema & $200 \mathrm{mil}$ & $30 \mathrm{mil}$ & $\mathrm{R} \$ 32$ milhões \\
\hline 9 & GP Brasil de Fórmula 1 & $140 \mathrm{mil}$ & $85 \mathrm{mil}$ & $\mathrm{R} \$ 238$ milhões \\
\hline 10 & Carnaval & $110 \mathrm{mil}$ & $32 \mathrm{mil}$ & $\mathrm{R} \$ 51$ milhões \\
\hline 11 & SP Fashion Week & $100 \mathrm{mil}$ & $22 \mathrm{mil}$ & $\mathrm{R} \$ 45$ milhões \\
\hline 12 & Hospitalar & $89 \mathrm{mil}$ & $47 \mathrm{mil}$ & $\mathrm{R} \$ 99$ milhões \\
\hline 13 & Couromoda & $65 \mathrm{mil}$ & $42 \mathrm{mil}$ & $\mathrm{R} \$ 74$ milhões \\
\hline 14 & Adventure Sports Fair & $61 \mathrm{mil}$ & $21 \mathrm{mil}$ & $\mathrm{R} \$ 20$ milhões \\
\hline 15 & Francal & $60 \mathrm{mil}$ & $40 \mathrm{mil}$ & $\mathrm{R} \$ 85$ milhões \\
\hline 16 & Equipotel & $50 \mathrm{mil}$ & $14 \mathrm{mil}$ & $\mathrm{R} \$ 4$ milhões \\
\hline 17 & Fenatran & $48 \mathrm{mil}$ & $15 \mathrm{mil}$ & $\mathrm{R} \$ 30$ milhões \\
\hline 18 & Fórmula Indy & $21 \mathrm{mil}$ & $\mathrm{R} \$ 80$ milhões \\
\hline
\end{tabular}

Fonte: SPTURIS, 2011

Como pode ser visto, o mercado de turismo de negócios e eventos em São Paulo merece atenção especial, não apenas pelo seu porte e pelos resultados que produz, mas também pelo potencial que oferece. 
Kotler mostra que: "Deve-se lembrar que os viajantes empresariais que pernoitam também esperam algum tipo de lazer, como entretenimento, atrações históricas ou belezas naturais. Isso significa que cada cidade precisa ser capaz de oferecer pacotes abrangentes e específicos que incorporem tanto ofertas de negócios quanto de lazer." (KOTLER et al. 2006, p. 248/249)

Para atender a esta demanda, a cidade de São Paulo tem, pelo menos sob o ponto de vista quantitativo, uma infraestrutura expressiva. Segundo o Plano de Turismo Municipal Cidade de São Paulo 2011-2014 (Platum), alguns dos números que comprovam isso são:

- Gastronomia

○ 12,5 mil restaurantes

○ 52 tipos de cozinhas

○ 15 mil bares

○ 3,2 mil padarias

○ 2 mil opções de delivery

○ São Paulo é a segunda maior cidade do mundo em número de restaurantes.

- Cultura e Lazer

- 280 salas de teatro

- 600 espetáculos teatrais por ano

○ 110 museus

○ 270 salas de cinema

○ 40 centros culturais

○ 64 parques e áreas verdes

○ 7 parques temáticos

- 294 salas para shows e concertos

- 1.000 academias de ginástica

○ 2 iates clubes

○ 12 clubes de golfe

- 7 estádios de futebol

- 1 autódromo internacional

- 88 bibliotecas

○ 41 áreas de patrimônio

○ 41 festas populares 
- Consumo

○ 240 mil lojas

○ 80 shoppings

○ 59 ruas especializadas em mais de 51 segmentos

○ 1.000 farmácias

○ 1.000 pet shops

- 900 feiras livres semanais

○ 1.931 agências bancárias

Evidentemente, para atender a toda essa demanda, a indústria hoteleira de São Paulo é de vital importância. Os dados da ABIH (2011) mostram que a cidade tem a seguinte estrutura hoteleira:

- Meios Hospedagem

- Unidades Habitacionais

- Leitos
367

29.532

52.512

Ou seja, comparados os dados da cidade com os dados do Brasil, nota-se que a cidade de São Paulo tem 6,2\% dos hotéis do Brasil, e 10,7\% das UHs, o que indica que os hotéis da cidade tendem a ser de maior porte que a média nacional.

A taxa de ocupação dos hotéis de São Paulo pode ser vista na tabela 9, onde se percebe que a taxa de ocupação média durante o ano é de $66 \%$, índice claramente influenciado pela menor ocupação nos meses das férias de verão (Dezembro, Janeiro e Fevereiro), o que comprova a vocação da cidade para o turismo de negócios e eventos.

Além disso, os índices mensais são calculados levando-se em conta todos os dias da semana, incluindo os fins de semana, onde a taxa é bem mais baixa, o que também contribui para que o índice médio seja aparentemente baixo. Como será visto nas pesquisas, a taxa de ocupação durante os dias da semana é próximo da capacidade máxima dos hotéis. 
Tabela 9 - Taxa de ocupação hoteleira na cidade de São Paulo em 2010

\begin{tabular}{|c|c|}
\hline Mês & Ocupação \\
\hline Janeiro & $50,29 \%$ \\
\hline Fevereiro & $53,65 \%$ \\
\hline Março & $71,45 \%$ \\
\hline Abril & $67,74 \%$ \\
\hline Maio & $71,34 \%$ \\
\hline Junho & $67,11 \%$ \\
\hline Julho & $65,14 \%$ \\
\hline Agosto & $73,92 \%$ \\
\hline Setembro & $70,98 \%$ \\
\hline Outubro & 69,33\% \\
\hline Novembro & $77,75 \%$ \\
\hline Dezembro & $53,53 \%$ \\
\hline Média anual & $66 \%$ \\
\hline
\end{tabular}

Fonte: ABIH, 2011

Como visto com os diversos dados apresentados, o setor de turismo e, consequentemente, o setor hoteleiro, representam um mercado extremamente importante para a economia do Brasil, como um todo, e para São Paulo, de maneira específica. Exatamente por isso foi decidido que o objeto da pesquisa fosse o setor hoteleiro.

Além disso, é fundamental lembrar que a hotelaria é um setor onde o uso de experiências, como visto na revisão teórica, pode e deve ser aplicado e desenvolvido.

KUAZAQUI (2000 - p. 6), afirma que "a indústria de entretenimento, viagens e turismo (e, dentro desta, os conceitos do setor hoteleiro), embora de maneira pulverizada, é a maior do mundo e todas as pesquisas, estudos, análises e projeções recentes feitos por entidades públicas e privadas ligadas a estes setores projetam que, nos próximos anos, haverá crescente consolidação e especialização.”

BENI (1998 - p. 187) também defende maior desenvolvimento na hotelaria. Segundo o autor, "a empresa hoteleira, um dos elementos essenciais da infraestrutura turística, constitui um dos suportes básicos para o desenvolvimento do Turismo num país. É pois necessário serem 
criadas redes de hotéis ou similares que satisfaçam as exigências das demandas interna e receptiva, tanto no que se refere à qualidade dos serviços quanto ao conforto.”

Esta tese pretende trazer uma contribuição para este setor. Uma das análises feitas pelo Documento Referencial Turismo no Brasil 2011/2014 é enfático nesta questão:

"Registra-se também a carência de referenciais de planejamento e gestão para o Turismo nestas diversas escalas. [...] O setor apresenta também carências no que se refere à profissionalização para a gestão, particularmente no nível gerencial, tanto no âmbito governamental quanto no setor privado." (p. 60)

Finalmente, fazendo o link entre alguns dos pontos já vistos na revisão bibliográfica, e também na justificativa para escolha do setor a ser pesquisado, cabe a ideia de BALANZÁ e NADAL (2003 - p. 155):

“Cada hotel é um mundo. É único e irrepetível, em certa medida, embora existam elementos que podem ser coincidentes em diversos hotéis, como a decoração, o tipo de construção, o estilo de gestão, os tipos de produtos; entretanto, existem outros elementos que não há como fazê-los coincidir, como a localização e, principalmente, o pessoal. O elemento que mais vai marcar a diferença em um serviço é o humano, todos aqueles profissionais que fazem possível acontecer a magia, a ilusão e a satisfação no consumo de um produto/serviço. O melhor hoteleiro será aquele que seja capaz de fazer seu negócio rentável, minimizando custos e otimizando os lucros, ao mesmo tempo em que saiba transmitir o encanto e o nível de satisfação que toda pessoa espera ao hospedar-se em seu estabelecimento". 


\subsection{Protocolos para a Pesquisa de Campo}

YIN (2010, p. 106) afirma que o protocolo é uma maneira importante de aumentar a confiabilidade da pesquisa de estudo de caso e se destina a orientar o pesquisador na realização da coleta de dados. Para isso, Yin sugere que o protocolo seja desenvolvido em 4 seções:

a) Visão geral do projeto do estudo de caso

b) Procedimentos de campo

c) Questões de estudo de caso

d) Guia para o relatório do estudo de caso

O protocolo de pesquisa desenvolvido para esta tese encontra-se no Apêndice A. 


\section{ANÁLISE DO TRABALHO DE CAMPO}

Para alcançar os objetivos propostos nesta tese, foi realizada uma pesquisa com 3 hotéis, todos eles da categoria 5 estrelas. Os hotéis escolhidos foram:

- Grand Hyatt

- Hilton

- L'Hotel Porto Bay

É importante destacar um ponto em relações às 3 unidades de análise escolhidas. Segundo o Trip Advisor, o Hyatt, o L'Hotel e o Hilton ocupam, respectivamente, o $2^{\circ}, 3^{\circ}$ e $4^{\circ}$ lugares na avaliação dos consumidores, de um total de 270 hotéis avaliados na cidade de São Paulo. (TRIP ADVISOR, 2011).

O TripAdvisor é o maior site de viagem do mundo, com mais 65 milhões de visitantes por mês, 20 milhões de membros, mais de 50 milhões de dicas, avaliações e opiniões. O site opera em 30 países, em 21 idiomas. Em visita ao site, realizada em 30/11/2011, a posição dos hotéis pesquisados era a seguinte:

Tabela 10 - Classificação dos hotéis

\begin{tabular}{|l|c|c|c|c|c|c|}
\cline { 2 - 7 } \multicolumn{1}{c|}{} & \multicolumn{2}{c|}{ Hyatt } & \multicolumn{2}{c|}{ L'Hotel } & \multicolumn{2}{c|}{ Hilton } \\
\hline Avaliação & Absoluto & $\%$ & Absoluto & $\%$ & Absoluto & $\%$ \\
\hline Excelente & 118 & 63,4 & 36 & 72,0 & 66 & 56,0 \\
\hline Muito Bom & 52 & 28,0 & 10 & 20,0 & 40 & 33,9 \\
\hline Razoável & 10 & 5,4 & 2 & 4,0 & 9 & 7,6 \\
\hline Ruim & 5 & 2,7 & 1 & 2,0 & 1 & 0,8 \\
\hline Péssimo & 1 & 0,5 & 1 & 2,0 & 2 & 1,7 \\
\hline \multicolumn{1}{|c|}{ Total } & $\mathbf{1 8 6}$ & $\mathbf{1 0 0 , 0}$ & $\mathbf{5 0}$ & $\mathbf{1 0 0 , 0}$ & $\mathbf{1 1 8}$ & $\mathbf{1 0 0 , 0}$ \\
\hline
\end{tabular}

Fonte: adaptado pelo autor com base em TRIP ADVISOR, 2011

Como pode ser observado, os hotéis analisados tem um índice de avaliação entre Excelente e Muito Bom na casa dos $90 \%$. Isto mostra a proximidade do nível de qualidade entre os três hotéis analisados. 
Esta proximidade também fica clara quando comparados os serviços oferecidos por cada um dos hotéis. A tabela 11 foi montada com base nas informações que os próprios hotéis colocam nos seus respectivos websites. Existem poucas diferenças entre os serviços oferecidos, e nenhuma dessas diferenças pode ser considerada uma grande vantagem competitiva.

Tabela 11 - Comparação dos serviços oferecidos

\begin{tabular}{|c|c|c|c|}
\hline FACILIDADES DO HOTEL & HILTON & HYATT & L'HOTEL \\
\hline Vista panorâmica & $\mathrm{X}$ & $\mathrm{X}$ & \\
\hline Internet de alta velocidade wireless e a cabo & $\mathrm{X}$ & $\mathrm{X}$ & $\mathrm{X}$ \\
\hline Cofre digital & $\mathrm{X}$ & $\mathrm{X}$ & $\mathrm{X}$ \\
\hline Cafeteira & $\mathrm{X}$ & $\mathrm{X}$ & \\
\hline TV de LCD de 32 polegadas & $\mathrm{X}$ & $\mathrm{X}$ & $\mathrm{X}$ \\
\hline Controle de temperatura & $\mathrm{X}$ & $\mathrm{X}$ & $\mathrm{X}$ \\
\hline Secador de cabelos & $\mathrm{X}$ & $\mathrm{X}$ & $\mathrm{X}$ \\
\hline Mini-bar completo & $\mathrm{X}$ & $\mathrm{X}$ & $\mathrm{X}$ \\
\hline TV a cabo/satélite & $\mathrm{X}$ & $\mathrm{X}$ & $\mathrm{X}$ \\
\hline Telefone com 2 linhas, viva voz e correio de voz & $\mathrm{X}$ & $\mathrm{X}$ & \\
\hline Área de trabalho & $X$ & $\mathrm{X}$ & \\
\hline Balança & & $\mathrm{X}$ & \\
\hline Roupões e chinelos & $\mathrm{X}$ & $\mathrm{X}$ & $\mathrm{X}$ \\
\hline Travesseiros e edredons de pena de ganso & $\mathrm{X}$ & $\mathrm{X}$ & $\mathrm{X}$ \\
\hline Roupa de cama $100 \%$ algodão & $\mathrm{X}$ & $\mathrm{X}$ & $\mathrm{X}$ \\
\hline Produtos de Banho & $\mathrm{X}$ & $\mathrm{X}$ & $\mathrm{X}$ \\
\hline Banheiros com banheira e ducha independentes & $\mathrm{X}$ & $\mathrm{X}$ & \\
\hline Banheiro de mármore & $X$ & $\mathrm{X}$ & $\mathrm{X}$ \\
\hline Concierge 24 horas & $\mathrm{X}$ & $\mathrm{X}$ & $\mathrm{X}$ \\
\hline Lounge exclusivo & $\mathrm{X}$ & $\mathrm{X}$ & \\
\hline Serviço de quarto 24 horas & $\mathrm{X}$ & $\mathrm{X}$ & $\mathrm{X}$ \\
\hline Serviço de turndown & $\mathrm{X}$ & $\mathrm{X}$ & \\
\hline Business Center & $\mathrm{X}$ & $\mathrm{X}$ & $\mathrm{X}$ \\
\hline Traslado para os Aeroportos & & $\mathrm{X}$ & $\mathrm{X}$ \\
\hline Lojas & $\mathrm{X}$ & $\mathrm{X}$ & \\
\hline Restaurantes & $\mathrm{X}$ & $X$ & $X$ \\
\hline Bar & $\mathrm{X}$ & $\mathrm{X}$ & $\mathrm{X}$ \\
\hline
\end{tabular}




\begin{tabular}{|l|c|c|c|}
\hline Spa & $\mathrm{X}$ & $\mathrm{X}$ & $\mathrm{X}$ \\
\hline Fitness Center & $\mathrm{X}$ & $\mathrm{X}$ & $\mathrm{X}$ \\
\hline Piscina climatizada & $\mathrm{X}$ & $\mathrm{X}$ & $\mathrm{X}$ \\
\hline Centro de Convenções & $\mathrm{X}$ & $\mathrm{X}$ & $\mathrm{X}$ \\
\hline Enoteca & & $\mathrm{X}$ & \\
\hline Rádio com alarme & $\mathrm{X}$ & $\mathrm{X}$ & $\mathrm{X}$ \\
\hline Cortinas black-out & $\mathrm{X}$ & & \\
\hline Ferro de passar roupa & $\mathrm{X}$ & $\mathrm{X}$ & $\mathrm{X}$ \\
\hline Equipamentos de áudio/vídeo & $\mathrm{X}$ & $\mathrm{X}$ & $\mathrm{X}$ \\
\hline Aluguel de telefone celular & $\mathrm{X}$ & & \\
\hline Serviço de Secretaria & $\mathrm{X}$ & $\mathrm{X}$ & $\mathrm{X}$ \\
\hline Cardápio infantil & $\mathrm{X}$ & & \\
\hline Escritório de Companhia Aérea & $\mathrm{X}$ & & \\
\hline Salão de beleza & $\mathrm{X}$ & & \\
\hline Escritório de aluguel de carro & $\mathrm{X}$ & & \\
\hline Lavanderia & $\mathrm{X}$ & $\mathrm{X}$ & $\mathrm{X}$ \\
\hline Serviço de Valet & $\mathrm{X}$ & $\mathrm{X}$ & $\mathrm{X}$ \\
\hline Comida vegetariana e kosher & $\mathrm{X}$ & & \\
\hline Estacionamento & $\mathrm{X}$ & $\mathrm{X}$ \\
\hline Personal shopper & & $\mathrm{X}$ \\
\hline
\end{tabular}

Fonte: elaborado pelo autor com base em HYATT SÃO PAULO (2011), HILTON (2011) e PORTO BAY (2011)

Nos próximos itens será apresentada a descrição de cada um dos casos para, em seguida, ser apresentado um resumo das conclusões tiradas. 


\subsection{Descrição do caso Grand Hyatt}

\subsubsection{Fontes de Informações consultadas}

\section{Páginas da internet}

HYATT. Disponível em: < http://www.hyatt.com >. Primeiro acesso em 05/10/2011

HYATT SÃO PAULO. Disponível em: < http://saopaulo.grand.hyatt.com.br > Primeiro acesso em 06/10/2011

TRIP ADVISOR. Disponível em: < www.tripadvisor.com > Primeiro acesso em 09/10/2011.

\section{Entrevistas}

Entrevista com a Sra. Karina Faber (FABER, 2011), Diretora de Comunicação Corporativa para América Latina, realizada no dia 29/11/2011, na sede do Grand Hyatt.

Entrevista com a Sra. Carolina Schramm (SCHRAMM, 2011), Gerente Assistente de ECommerce, realizada no dia 29/11/2011, na sede do Grand Hyatt.

\section{Observações}

Observações presenciais realizadas no Grand Hyatt nos dias 29/11/2011 e 01/12/2011.

\subsubsection{Informações gerais sobre o Hotel}

Hyatt foi fundada por Jay Pritzker em 1957, quando ele comprou o Hyatt Casa Motel - um pequeno motel ao lado do Aeroporto Internacional de Los Angeles, na California.

Na década seguinte, Jay Pritzker e seu irmão Donald, trabalhando em conjunto com outros negócios da família, fizeram a empresa crescer e se tornar uma grande companhia da área hoteleira - o Hyatt Corporation - abrindo seu capital em 1962. 
O Hyatt ganhou fama após inaugurar o Hyatt Regency Atlanta, que foi um dos primeiros hotéis com um grande atrium.

Em 1968 é criado o Hyatt International, também uma empresa com ações na bolsa, e em 1969 é inaugurado o primeiro hotel Hyatt no exterior, o Hyatt Regency Hong Kong.

As duas empresas - Hyatt Corporation e Hyatt International Corporation - fecharam seu capital e voltaram a ser totalmente controladas pela família Pritzker em 1979 e 1982, respectivamente.

Em 1980 são lançadas as marcas Grand Hyatt e Park Hyatt, e a companhia começa a operar também o conceito de resort, com a inauguração do Hyatt Regency Maui.

Em 2004 o Hyatt compra a cadeia de hotéis AmeriSuites, que passa a se chamar Hyatt Place.

Em 2005 o grupo compra a cadeia Summerfield Suites, que em 2012 passará a se chamar Hyatt House. Em 2011, o grupo compra a cadeia Hotel Sierra, com 18 hotéis, e que em 2012 também terá a marca Hyatt House.

Em 30/09/2011 o grupo tinha hotéis em cerca de 400 cidades no mundo, gerenciando oito marcas distintas, conforme podemos ver na tabela 12 :

Tabela 12 - Portfolio de Marcas do Hyatt Hotels Corporation

\begin{tabular}{|c|c|c|}
\hline Marca & Hotéis & Quartos \\
\hline Park Hyatt & 26 & 5.093 \\
\hline Andaz & 5 & 1.101 \\
\hline Grand Hyatt & 37 & 21.109 \\
\hline Hyatt Regency & 148 & 67.694 \\
\hline Hyatt & 25 & 5.827 \\
\hline Hyatt Place & 162 & 20.532 \\
\hline Hyatt Summerfield Suites & 52 & 7.308 \\
\hline Hyatt Residence Club & 23 & 2.193 \\
\hline Total & 478 & $\mathbf{1 3 0 . 8 5 7}$ \\
\hline
\end{tabular}

Fonte: Adaptado de HYATT (2011) - 30/9/2011 
Segundo o site do Grupo, um dos destaques do Hyatt é o fato de seus hotéis terem um toque da cultura local, seja em termos de arquitetura e/ou da culinária. É interessante ver que o site destaca este ponto, afirmando que isto "proporciona uma experiência a um só tempo singular e que satisfaz todas as expectativas”. Observa-se que a promessa de experiência está presente aqui.

O grupo tem 85 mil funcionários, e em 2010 obteve uma receita de US\$ 3,5 bilhões, e um lucro de US\$ 66 milhões.

Em 2010, o Hyatt Gold Passport, programa de fidelidade do grupo, tinha cerca de 10 milhões de membros, que representaram por volta de $25 \%$ das diárias do ano.

\subsubsection{Hotel Pesquisado}

A unidade de análise foi o hotel Grand Hyatt São Paulo, localizado na Av. das Nações Unidas, 13301, São Paulo, SP.

Este é o único hotel Hyatt no Brasil. Existe outro que está sendo construído na cidade do Rio de Janeiro, mas ainda sem data de inauguração fixada.

De acordo com o site do hotel (HYATT São Paulo, 2011), o hotel oferece a seguinte estrutura:

\section{Acomodações}

O hotel tem 466 Apartamentos e Suítes com as seguintes comodidades:

- Apartamento com $41 \mathrm{~m}^{2}$.

- Janelas com vista panorâmica

- Acesso à internet de alta velocidade wireless e a cabo

- Cofre digital

- Cafeteira

- $\quad$ TV de LCD de 32 polegadas 
- Controle de temperatura

- Secador de cabelos

- Mini-bar completo

- TV a cabo/satélite

- Aparelhos de telefone com duas linhas, viva voz e correio de voz

- Área de trabalho

- Balança digital

- Roupões

- Travesseiros e edredons de pena de ganso

- Roupa de cama 100\% algodão

- Produtos de Banho Granado

- Decoração contemporânea com madeiras e elementos naturais

- Cama king size com cabeceira de madeira Louro Faia

- Banheiros espaçosos com banheira e ducha independentes, além de um exclusivo trabalho de mosaico de mármore importado da Itália

- Rádio com alarme

- Ferro de passar roupa

\section{Serviços ao Hóspede}

Os principais serviços oferecidos pelo hotel aos seus hóspedes são:

- Concierge 24 horas

- Serviço no Grand Club \& Lounge

- Serviço de quarto 24 horas

- Serviço de turndown

- Hotel Business Center

- Traslado para os Aeroportos de Congonhas e Guarulhos

- Lojas

- 3 restaurantes (Italiano, Francês e Japonês)

- Bar de vinhos

- Spa

- Fitness Center 
- Piscina coberta climatizada e piscina externa

- Centro de Convenções para 1.350 pessoas

- Enoteca revestida de vidro

- Equipamentos de áudio/vídeo

- Serviço de Secretaria

- Lavanderia

- Serviço de Valet

- Estacionamento

O Hyatt conta com 600 funcionários, sendo que quase 50\% destes atuam na área de Alimentos e Bebidas, já que o hotel tem um foco nesta área, além de ter muitos serviços de banquete.

\subsubsection{Questões gerais de Marketing}

O hotel tem uma taxa de ocupação de $80 \%$, ou seja, 14 pontos percentuais acima da taxa média de ocupação na cidade de São Paulo.

A tarifa média gira entre $R \$ 650,00$ e $R \$ 750,00$ durante a semana, caindo para cerca $R \$$ 495,00 nos fins de semana. Como já apontado, o turismo na cidade de São Paulo tem um foco maior no segmento de turismo de negócios e eventos - por isso, a taxa de ocupação dos hotéis tende a ser menor nos fins de semana. Para tentar diminuir esta sazonalidade, os hotéis oferecem descontos e promoções especiais nos fins de semana.

O foco maior no segmento de turismo de negócios e eventos, que gera uma maior concentração de hóspedes durante os dias de semana, pode ser comprovado pelo perfil dos hóspedes, basicamente formado pelo público corporativo entre $2^{\mathrm{a}}$ e $5^{\mathrm{a}}$ feira. No fim de semana, o perfil muda um pouco, com ênfase em grupos de lazer.

Os hóspedes, tanto no segmento corporativo, quanto no de lazer, são divididos entre brasileiros e estrangeiros. No público estrangeiro, há uma predominância de norte-americanos (cerca de 70\%), seguido por ingleses e alemães. 
No segmento corporativo é importante destacar alguns acordos com empresas brasileiras e estrangeiras, incluindo a tripulação de companhias aéreas, que também representam uma pequena parte dos hóspedes.

Segundo FABER (2011), as principais características que diferenciam o hotel são:

a) Forte atuação na área de Alimentos e Bebidas, com a oferta de três restaurantes de alta categoria, divididos entre culinária italiana, japonesa e francesa.

b) O spa do hotel, não apenas de grande porte, como também reconhecido como um dos melhores spas urbanos da cidade.

c) Os andares executivos, que oferecem apartamentos com serviços exclusivos, como recepção privativa para check in e check out, concierge exclusivo, sala de reuniões com uso gratuito de até uma hora por dia, local próprio para café da manhã e lounge executivo exclusivo.

d) Outro diferencial apontado é o fato dos apartamentos terem $41 \mathrm{~m}^{2}$, considerado um dos maiores na categoria. Neste apartamento, destaca-se também a banheira e o chuveiro serem separados.

As estratégias gerais de marketing são definidas na matriz do grupo, nos Estados Unidos. No entanto, a maioria das ações é desenvolvida localmente. Dentre estas ações destacam-se um calendário promocional na área de hospedagem, gastronomia e no spa.

De acordo com FABER (2011):

"Nosso calendário promocional é dividido em três áreas: hospedagem, gastronomia e spa. Isso significa que falamos com três públicos diferentes, ainda que haja sobreposição entre eles. Os três restaurantes nos aproximam muito da comunidade local, ou seja, não são restaurantes apenas para o hotel e sim para a cidade. Isso gera muito relacionamento com clientes que não são hóspedes, mas pessoas que vem para fazer um almoço de negócios, para jantar, etc... O mesmo acontece com o spa." 
Este calendário inclui festas como Natal, Reveillon, Carnaval, além de pacotes específicos para eventos que acontecem na cidade, como a Fórmulal ou o show com Eric Clapton.

Também na área promocional encontramos ações específicas, especialmente nos restaurantes, com festivais gastronômicos, degustações de vinhos, e jantares exclusivos para os participantes dos programas de fidelidade que o hotel possui - o Gold Passport.

O Hyatt também tem alguns brindes que são oferecidos para hóspedes especiais, principalmente os que fazem parte do seu programa de fidelidade. Dentre estes brindes podem ser citados pequenas caixas de macarons, $\mathrm{CD}$, flores ou um livro de receitas feito pelos chefs dos restaurantes do hotel.

Segundo Schramm (2011) "este livro engloba alguns dos sentidos, porque explora o visual com a imagem das fotos que foram feitas aqui, e o paladar, com as receitas criadas pelos nossos chefs, e isso faz com que o hóspede se lembre de nós."

A satisfação dos clientes é medida através de uma pesquisa que atinge cerca de $1 / 3$ dos hóspedes. A metodologia da pesquisa foi desenvolvida especificamente para a cadeia Hyatt, e chama-se Merits. Essa metodologia analisa vários critérios, como tecnologia, serviços, atendimento, etc... Com base nos resultados, o hotel desenvolve treinamentos para melhorar as áreas em que foram apontados problemas.

Além do formulário padrão, o hóspede também pode responder a pesquisa diretamente no site do hotel. Com essa padronização, o grupo pretende uniformizar os critérios de avaliação, bem como proporcionar a oportunidade de mensuração e comparação entre os diferentes hotéis do grupo, na medida em que um hotel tem acesso aos resultados de outro hotel.

O Hyatt também usa como parâmetro de avaliação os resultados mostrados no Trip Advisor. Essa ação não é isolada. Os resultados das pesquisas são levados pra dentro do hotel e discutidos com as áreas envolvidas. O hotel também tem contato direto com os hóspedes, principalmente por meio de um programa de fidelidade local, que proporciona um contato bem mais pessoal com os clientes.

Por fim, é importante destacar a questão do posicionamento do hotel. Segundo Faber, 
"o posicionamento do Hyatt é o de um hotel internacional, de padrão superior, 5 estrelas. Quando chegamos ao Brasil havia poucas redes internacionais aqui em SP, e nossa marca não era muito conhecida pelos brasileiros. A referência que os brasileiros tinham era do Hyatt americano, que era diferente do Hyatt internacional. Hoje isso está mudando porque a companhia esta se homogeneizando. Com um branding mais homogêneo, fica mais fácil nosso posicionamento de padrão superior de um hotel internacional." (FABER, 2011)

Dentro deste posicionamento, destaca-se uma postura low profile em relação aos hóspedes. Sobre isso, SCHRAMM (2011) diz que

"nós temos uma política de privacidade dos hóspedes muito grande, que é uma política do Hyatt. O Hyatt não explora a estadia das celebridades. Nós recebemos muitas celebridades aqui, mas não exploramos isso. E muitas pessoas acabam retornando exatamente por causa desta privacidade."

\subsubsection{Visão sobre Marketing Experiencial}

A visão que o hotel Hyatt tem sobre Marketing Experiencial parece um pouco confusa. Para FABER (2011), "Marketing Experiencial é a capacidade de posicionar o produto de uma forma aspiracional."

Esta é uma visão parcial e que foge um pouco do que foi abordado na fundamentação teórica. Evidentemente que a crítica à esta visão parcial parte da comparação desta visão com o conceito de Marketing Experiencial sob o ponto de vista acadêmico. E, ainda assim, deve-se lembrar de que no referencial teórico estudado, foi visto que o conceito de Marketing Experiencial ainda não tem um consenso.

Por isso, a visão de Faber, apesar de parcial, não pode ser considerada completamente errada, ainda mais levando-se em conta que sua visão a respeito de alguns conceitos tem o viés da organização e do mercado em que atua. 
Ou seja, a afirmação de que Marketing Experiencial é posicionar o produto de forma aspiracional pode ser entendido como coerente para um hotel 5 estrelas, ou seja, pode-se deduzir que a afirmação poderia ser entendida como "Marketing Experiencial é a capacidade de posicionar o HOTEL de uma forma aspiracional." (complemento e grifo do autor)

FABER (2011) também coloca que "o hóspede de lazer tem uma expectativa maior de boa experiência do que o hóspede corporativo." Neste caso, a análise da executiva está em consonância com aquilo foi visto na fundamentação teórica, ou seja, os produtos e serviços de características mais hedônicas, como é o hóspede de lazer, tende a ter uma expectativa maior se comparado com o hóspede corporativo, cujo consumo tende a ser um pouco mais utilitário."

Porém, a tentativa de agradar tanto o hóspede corporativo como o hóspede de lazer, reconhecendo que as expectativas são diferentes não é um trabalho simples. Sobre isso, Faber afirma que:

"Isso é um desafio para nós, pois sendo um hotel corporativo, temos que trocar o chapéu para atender o hóspede que está aqui para lazer, já que a expectativa dele sobre esta coisa sonhadora, sobre a experiência, é maior que a expectativa do hóspede corporativo. $O$ que trabalhamos mais em comunicação não é a praticidade e facilidade que o hotel oferece, porque isso é intrínseco ao produto. Isso foi desenhado e funciona bem. O que a gente tem que trabalhar é o sonho da experiência com os hóspedes de lazer." (FABER, 2011)

Esta afirmação pode parecer um pouco incoerente, na medida em que o Hyatt assume que é um hotel corporativo, mas usa, principalmente em sua comunicação, o apelo da experiência e do sonho.

No entanto, analisando um pouco mais, veremos que essa incoerência não é grande. Como visto anteriormente, KOTLER et al. (2006, p. 248/249) mostra que os turistas corporativos também se interessam por atividades de lazer. Portanto, se a facilidade e a praticidade que um hóspede corporativo quer já faz parte do produto esperado do hotel, é compreensível que sua 
comunicação busque posicioná-lo de maneira aspiracional, a partir da oferta de experiências únicas.

Com isto, entende-se que é coerente a promessa de experiência única que é colocada em algumas peças de comunicação do hotel, como observado na ilustração 1, que mostra a home page do site do hotel destacando esta promessa.

\section{Ilustração 1: Home page do site do Hyatt}

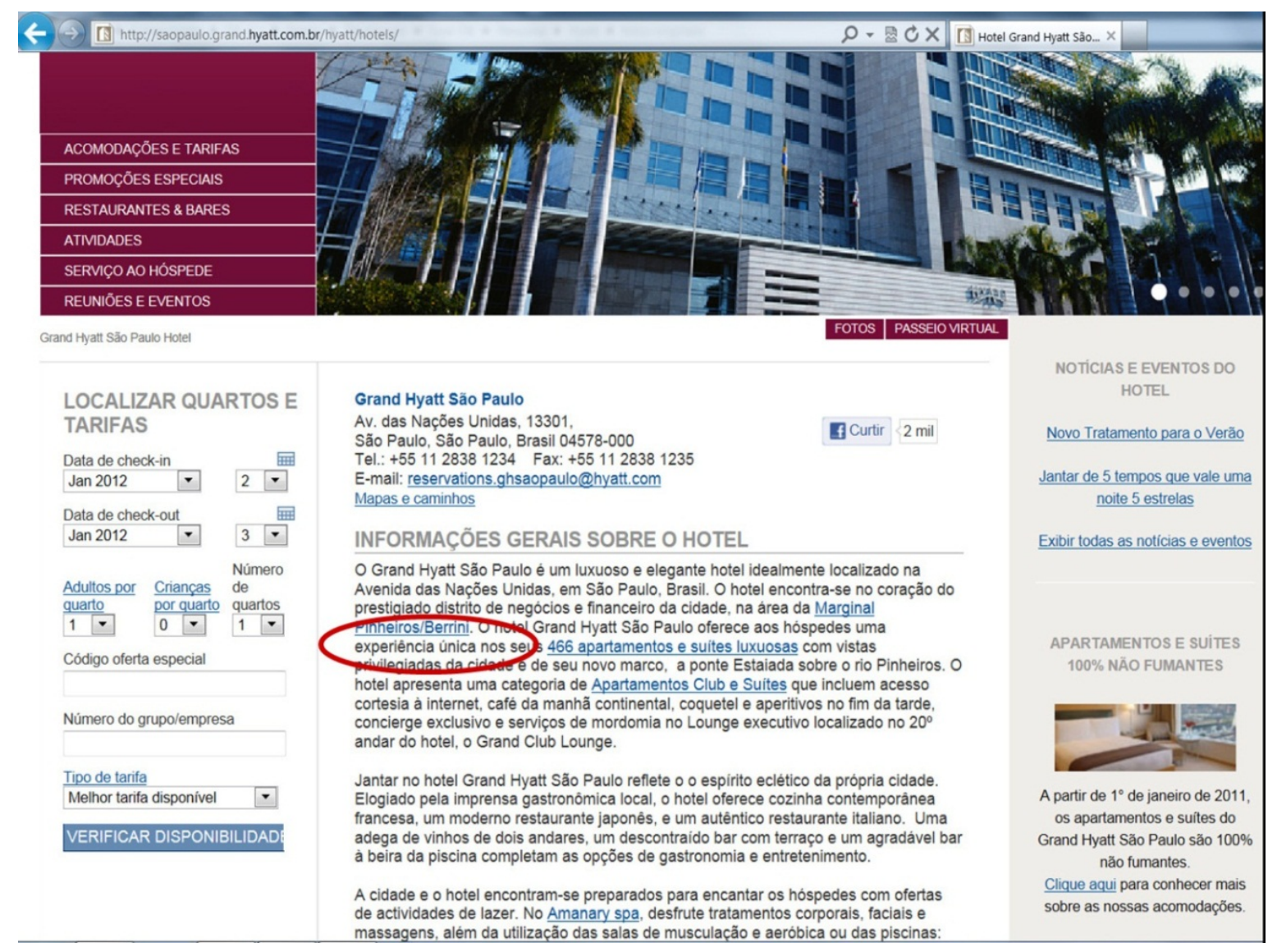

Fonte: HYATT SÃO PAULO, 2011

Questionados sobre eventuais ações de marketing experiencial desenvolvidas, foram citadas algumas. Para os participantes do programa Gold Passport, são feitos pequenos jantares com harmonização de vinhos. Em dezembro de 2011, para exemplificar, o Hyatt trouxe o dono de uma bodegueria argentina, que fez toda uma harmonização de vinhos. Também são oferecidos cursos de apresentação de pratos e a possibilidade de se cozinhar com o chef. Neste evento, é interessante notar a ideia de ofertar uma atividade customizada. 
Basicamente, a ação consiste nos participantes irem junto com o chef de cozinha até um determinado mercado e comprarem os ingredientes de que gostam, evidentemente com as indicações do chef. Na volta para o hotel, aprendem como elaborar seus pratos favoritos, com os ingredientes comprados.

Outra ação que chama atenção foram os eventos que são feitos para um grupo chamado de "Privates Line", composto por secretárias de executivos, que tem alto índice de reservas no hotel.

Para este grupo o Hyatt desenvolve uma série de eventos do tipo "Como transformar sua casa num hotel 5 estrelas", onde são ensinadas técnicas de arrumação de quartos, cama, mesas de jantar, etc... Evidentemente, o objetivo final desta ação é apresentar o hotel para um público que tem enorme poder de influência (e muitas vezes de decisão) na escolha dos hotéis que seus chefes irão se hospedar.

O hotel também procura colher informações mais detalhadas sobre os hóspedes mais frequentes, para que se possa oferecer um serviço mais customizado na próxima visita. Um exemplo disto pode ser verificado numa das visitas feitas. Um apartamento executivo estava preparado para um hóspede argentino que chegaria naquela noite. O quarto tinha um bilhete nominal ao hóspede desejando boas-vindas, junto a um brinde desejando uma boa estadia. $\mathrm{O}$ brinde era um produto que o hóspede sempre pedia quando se hospedava lá.

Para isto, o hotel tem um programa chamado "Random Acts of Generosity", em que os funcionários tem autonomia para fazer algo que passe a ideia hospitalidade de maneira mais autêntica, como oferecer uma massagem no spa, ou um pequeno almoço.

É claro que, para que isto funcione corretamente, o staff do hotel deve estar bem treinado. $\mathrm{O}$ treinamento é feito na academia corporativa do hotel, ligada à área de Recursos Humanos. Nesta academia são oferecidos treinamentos diversos para todos os funcionários, que vão de treinamentos de liderança até técnicas de como arrumar uma cama. 


\subsubsection{Ações Sensoriais}

\section{Visão}

Não existe um padrão visual para a arquitetura e decoração dos Hotéis Hyatt. Na verdade, dificilmente, sob o ponto de vista arquitetônico, um Hyatt é igual ao outro. A empresa entende que deve haver certa adaptação em relação à cultura local. Neste sentido, o Grand Hyatt São Paulo tem uma decoração neutra, com a utilização de madeiras e fibras brasileiras, estofados com tecidos e materiais nacionais, além de obras de arte também de artistas brasileiros.

Um exemplo disto pode ser visto nas três ilustrações seguintes. A ilustração 2 mostra a foto do lounge executivo, onde se destacam as cadeiras feitas com fibras brasileiras, assim como o carpete.

Ilustração 2: Lounge executivo com cadeiras feitas com fibras brasileiras

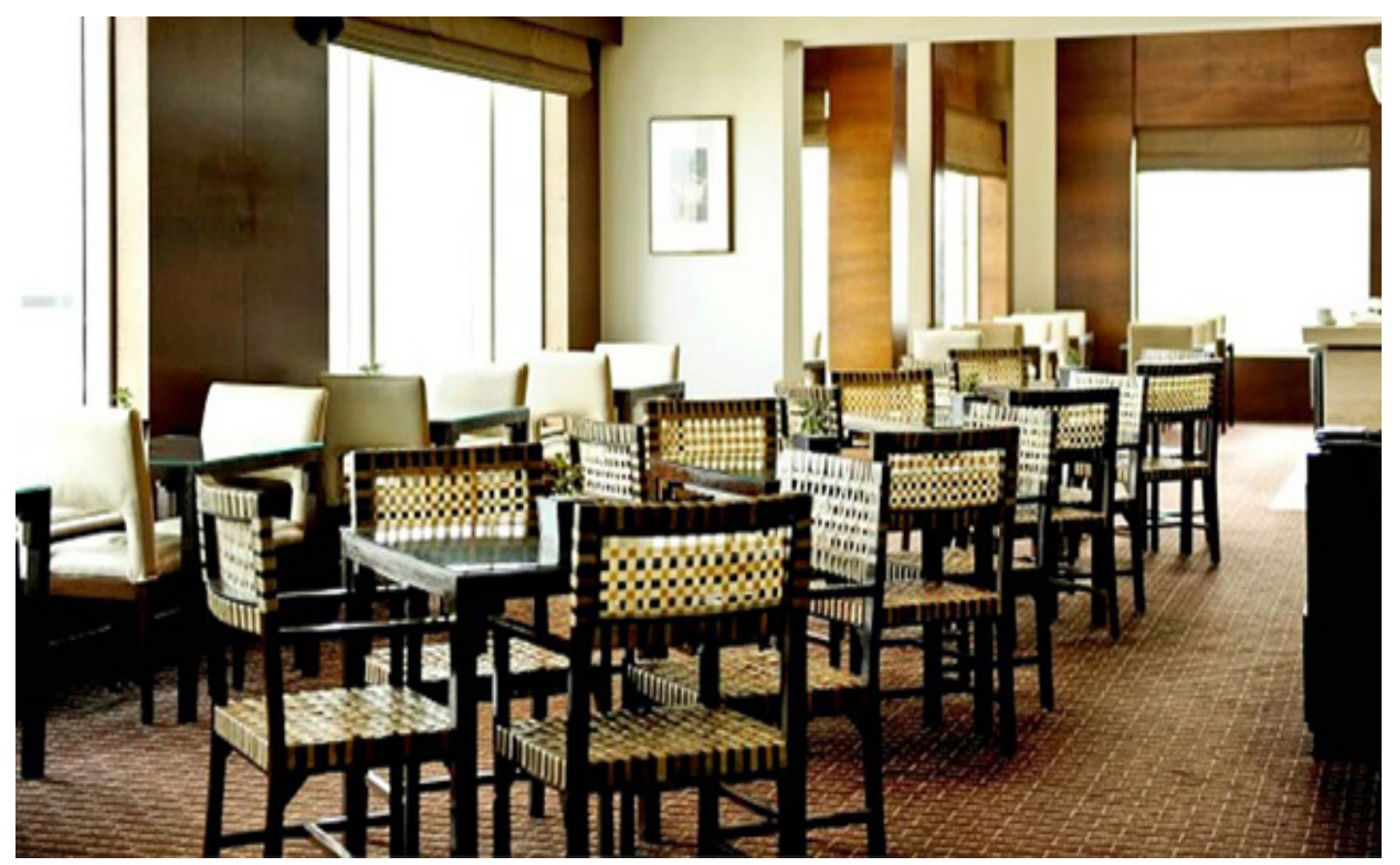

Fonte: HYATT SÃO PAULO, 2011

Na ilustração 3 pode ser vista a foto de um dos quadros que decora a recepção do hotel, criado por artista brasileiro. E na ilustração 4, os móveis que decoram a recepção do spa, também feitos com tecidos e madeiras nacionais. 
Ilustração 3: Obra de arte de artista brasileiro exposta no lobby do hotel

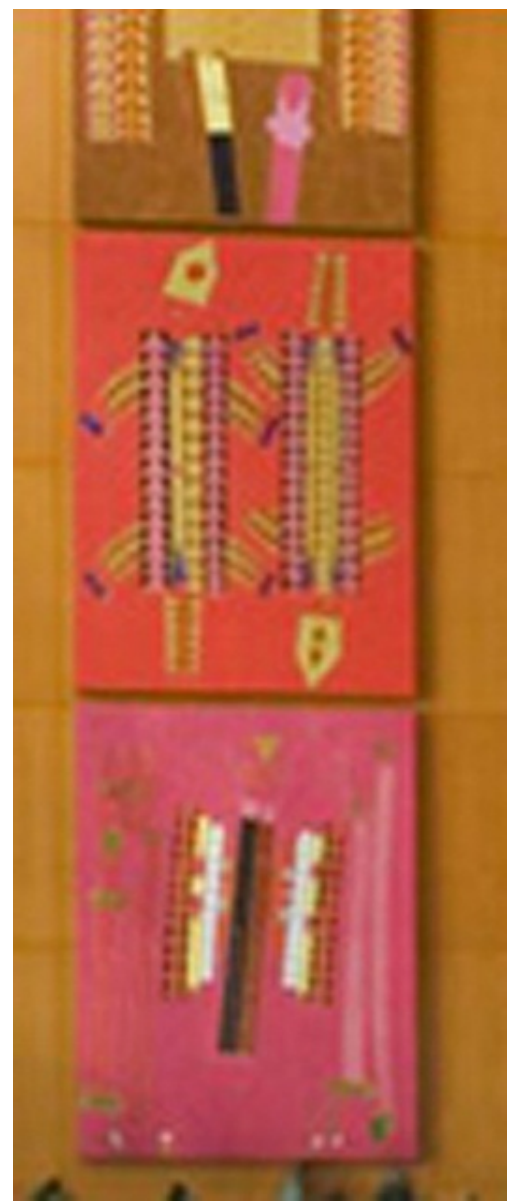

Fonte: HYATT SÃO PAULO, 2011

Ilustração 4: Móveis da recepção do spa, feitos com madeiras e tecidos brasileiros

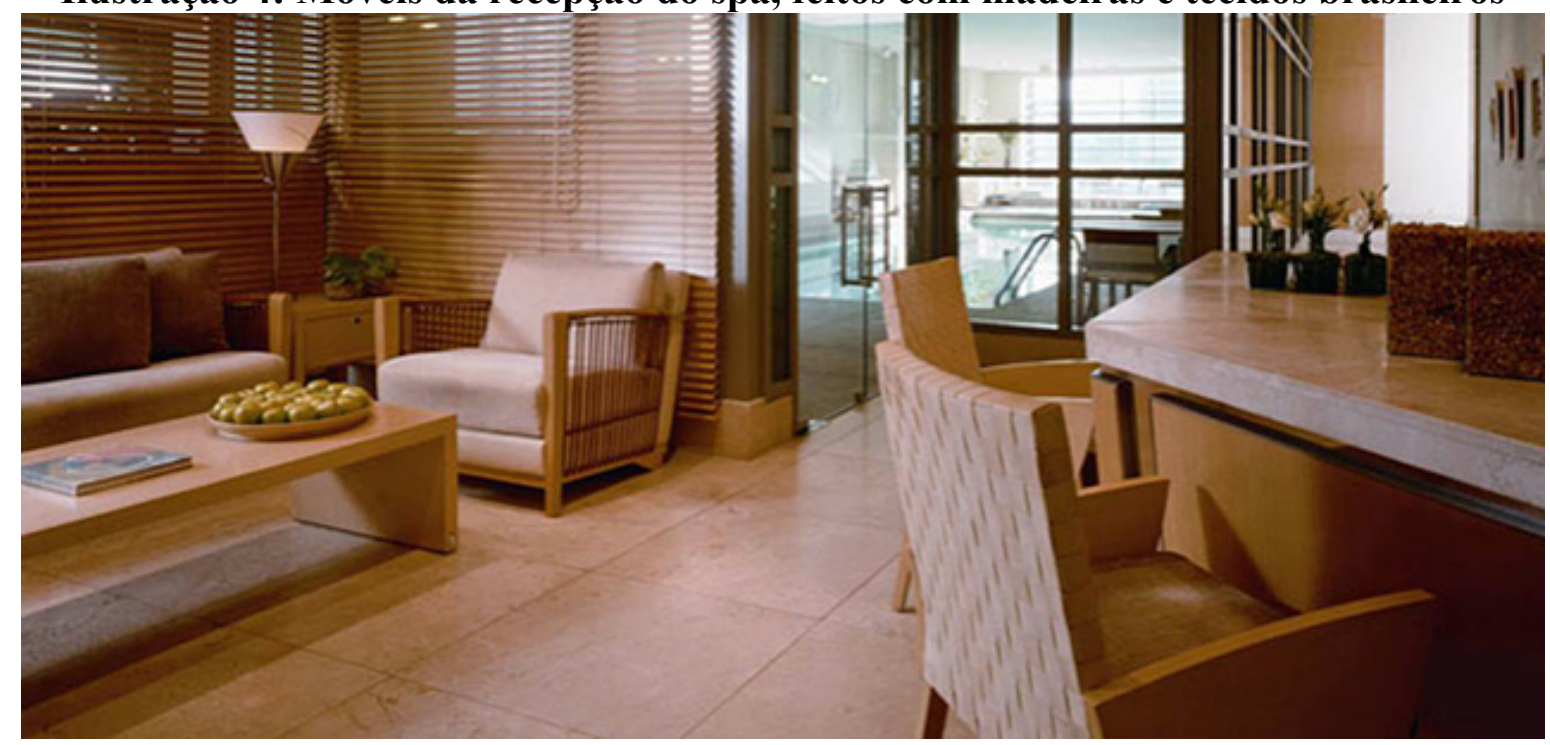

Fonte: HYATT SÃO PAULO, 2011 
Além do uso frequente de artigos de decoração feitos com materiais brasileiros, a decoração do hotel tem um conceito clean, moderno e sóbrio. Este conceito clean pode ser visto pelo uso de poucos elementos de decoração, dando um ar mais leve aos ambientes. A modernidade e a sobriedade ficam evidentes no design dos diferentes ambientes, com uso de cores neutras e peças de decoração elegantes e atemporais, mas sem nenhuma ousadia mais eloquente.

As ilustrações 5, 6, 7 e 8 comprovam isso. Nelas, observa-se o conceito de decoração sendo aplicado em ambientes diversos, como o fitness center, o restaurante Grand Caffé (onde também podem ser vistos os quadros de artistas brasileiros), o business center, e o Upstairs Lounge, respectivamente.

No fitness center, por exemplo, é evidente a imagem de modernidade nos aparelhos de ginástica, onde todos são computadorizados, além do uso de aparelhos de televisão de tela plana decorando o ambiente.

\section{Ilustração 5: Fitness center}

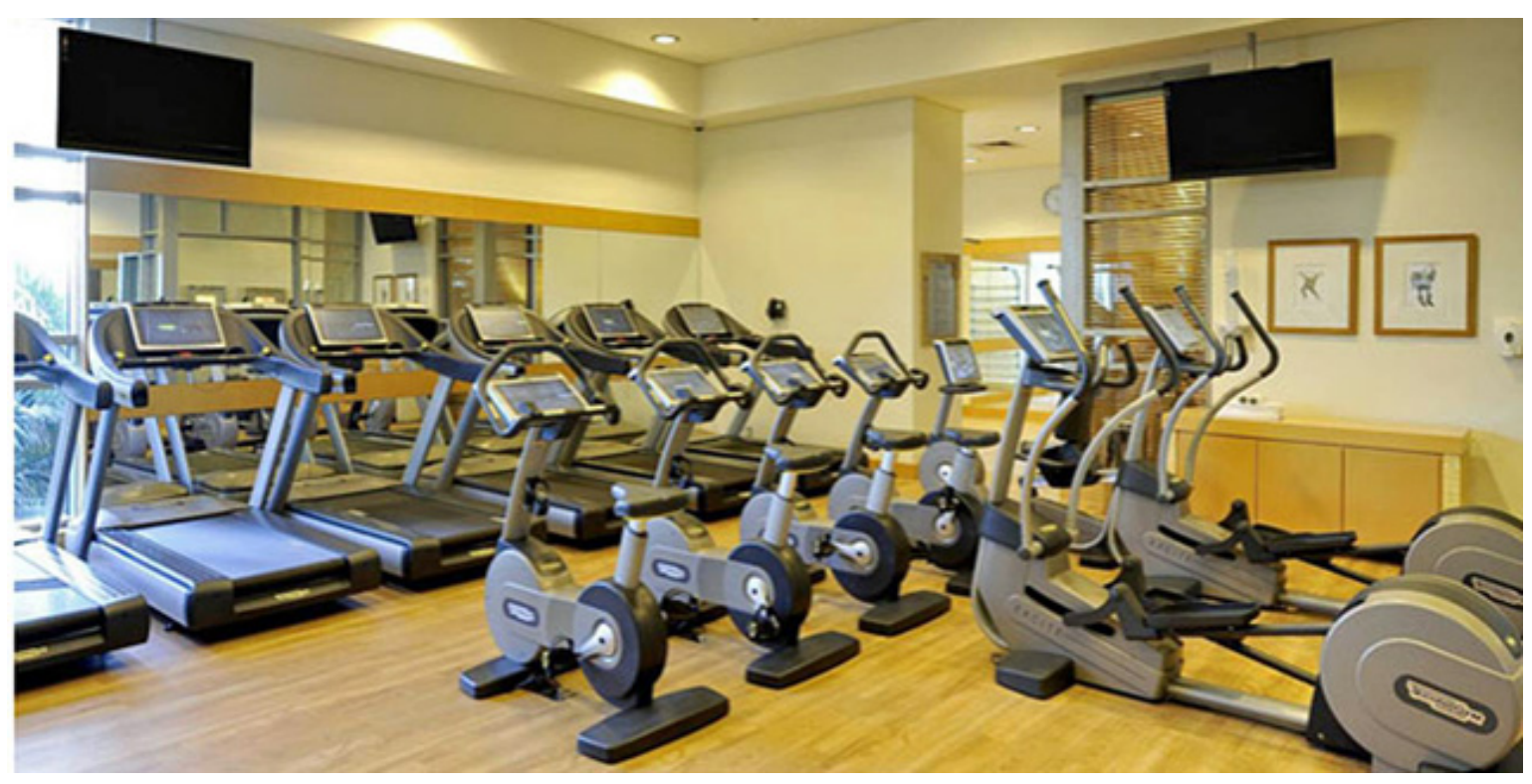

Fonte: HYATT SÃO PAULO, 2011 
Ilustração 6: Restaurante Grand Caffé

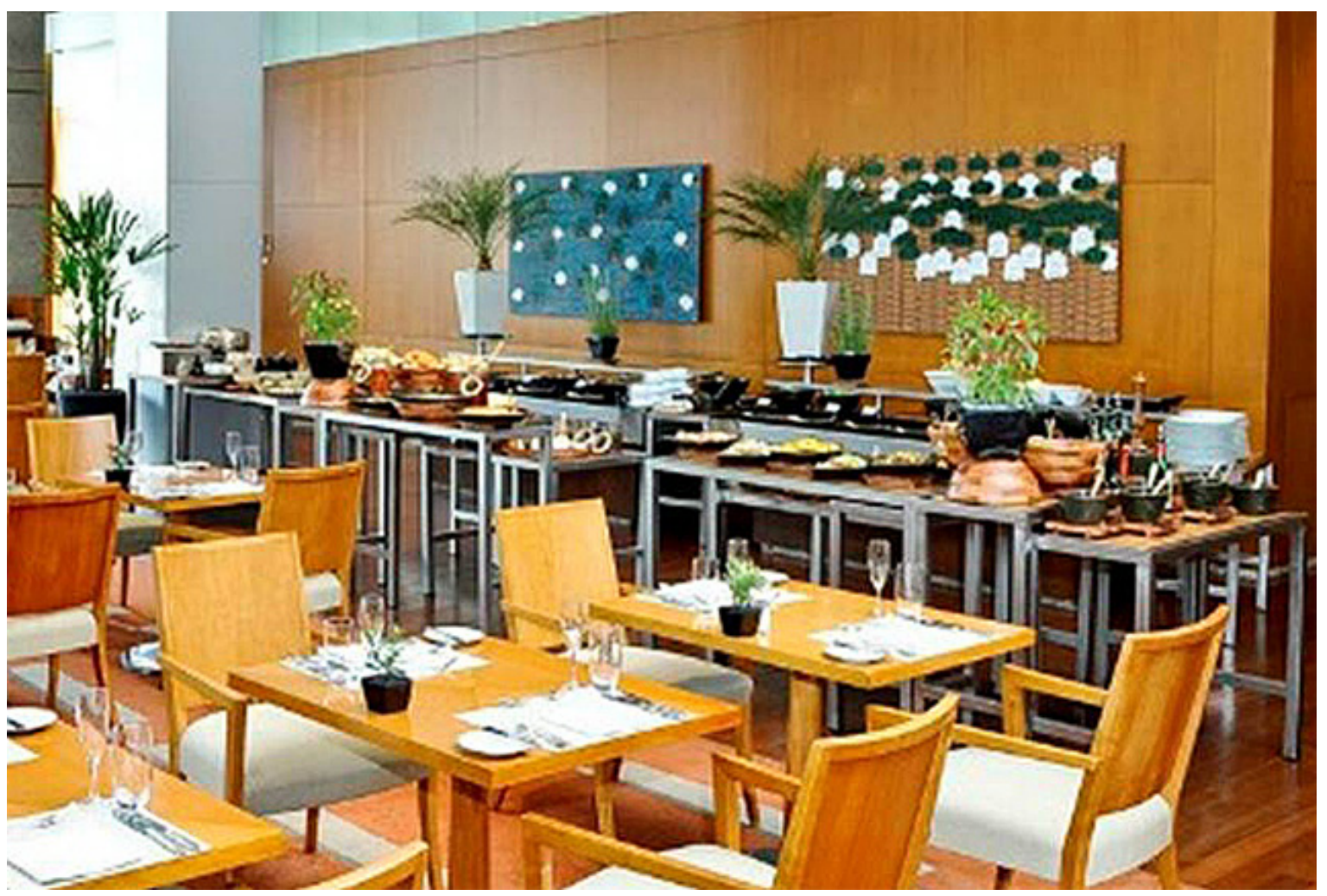

Fonte: HYATT SÃO PAULO, 2011

Ilustração 7: Business center

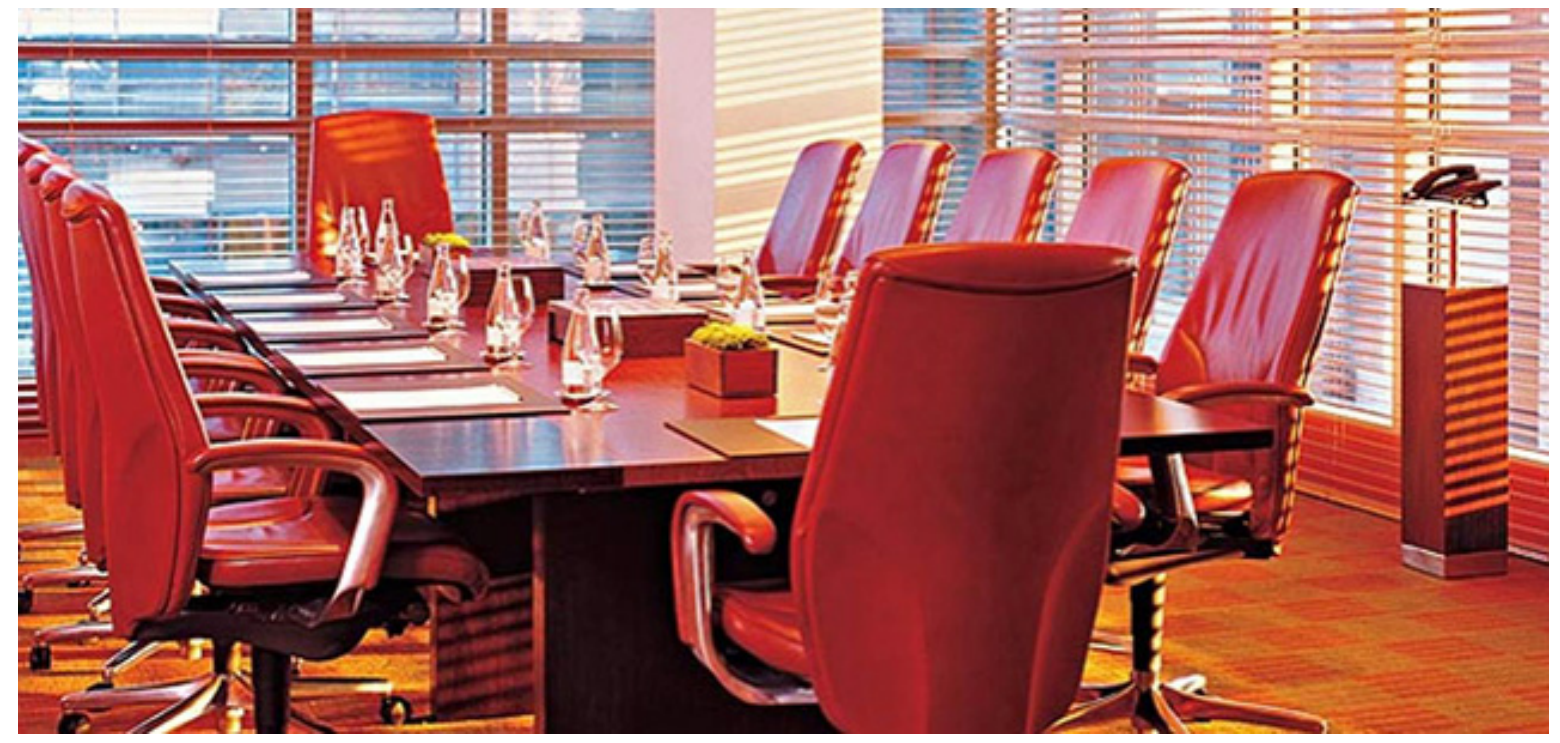

Fonte: HYATT SÃO PAULO, 2011 


\section{Ilustração 8: Upstairs Lounge}

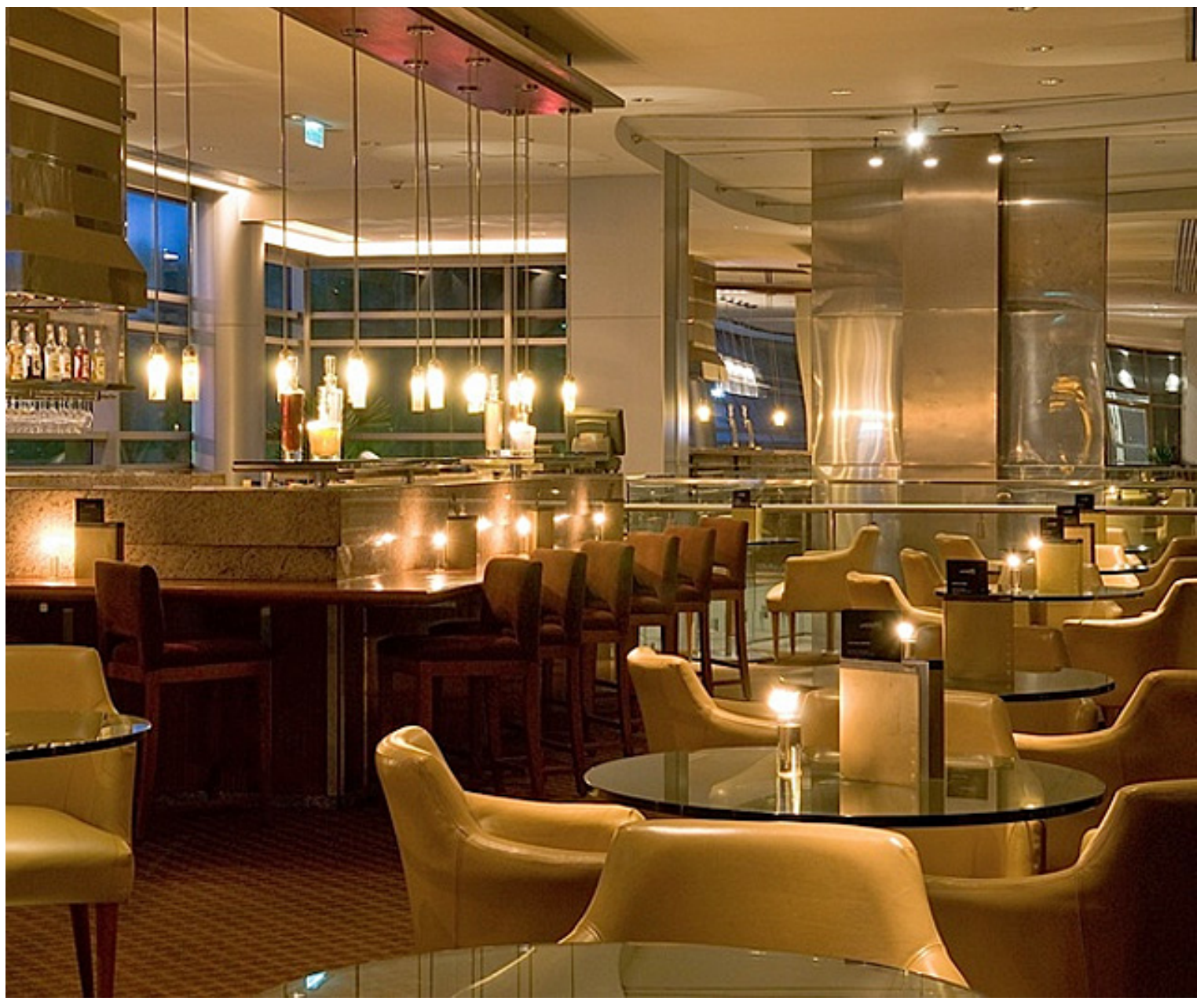

Fonte: HYATT SÃO PAULO, 2011

Outro ponto que merece destaque é o fato de que cada marca do grupo Hyatt tem algumas características que são específicas. Neste caso, o hotel de São Paulo é da marca Grand Hyatt que, como o próprio nome indica, tem como característica mais marcante no seu conceito e posicionamento, a ideia de grandeza, que deve se fazer presente também nos aspectos visuais.

Isto é facilmente percebido em alguns pontos e, de início, podem ser destacados dois deles, que tem uma importância significativa na medida em que são os primeiros contatos que os hóspedes tem com o hotel: o prédio em si, e seu lobby. O prédio do hotel é bastante imponente, com seus 466 apartamentos e mais de 20 andares (ilustração 9), e chama a atenção de qualquer transeunte. Os materiais usados na fachada, bem como seu design arquitetônico também colaboram para a ideia de grandeza. 


\section{Ilustração 9: Fachada do hotel}

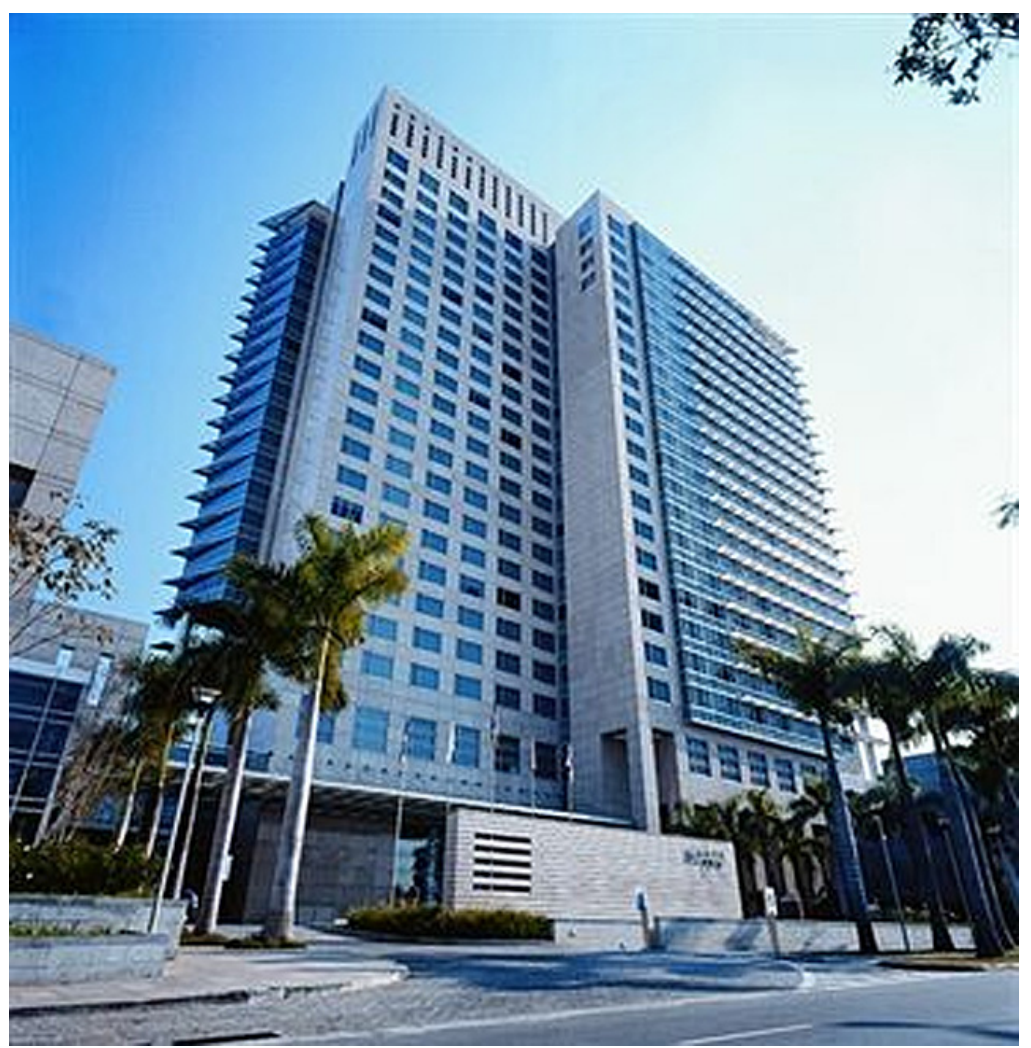

Fonte: HYATT SÃO PAULO, 2011

Esta imagem de imponência fica ainda mais evidente quando, na entrada no hotel, depara-se com um lobby com pé direito de 10 metros e uma decoração bastante clean, com poucos móveis, o que aumenta ainda mais a noção de grandiosidade, como visto na ilustração 10 .

\section{Ilustração 10: Lobby do hotel}

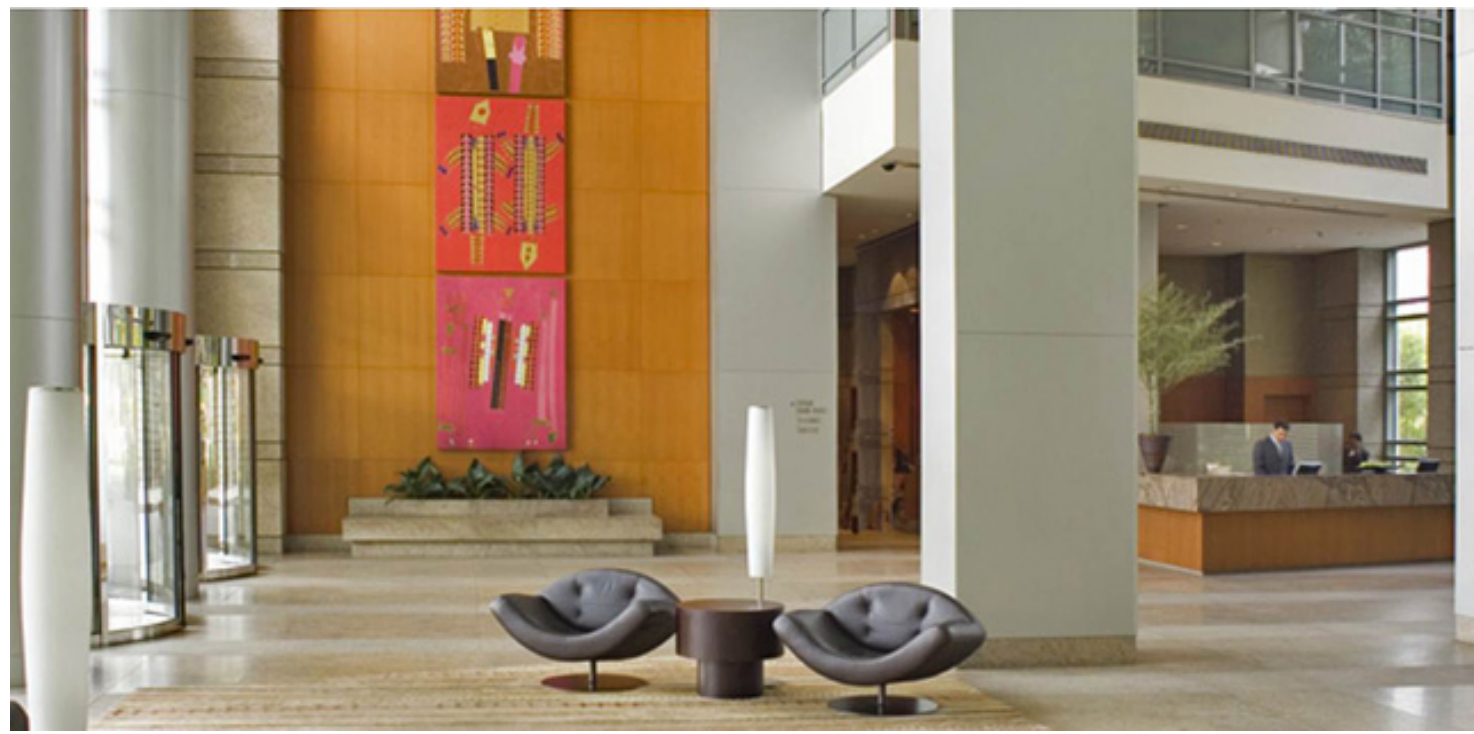

Fonte: HYATT SÃO PAULO, 2011 
Este conceito de grandiosidade se estende para outras áreas do hotel. Isto é percebido, por exemplo, no Centro de Convenções, que tem $3.000 \mathrm{~m}^{2}$, sendo um dos maiores da cidade.

Este Centro de Convenções pode receber até 1.350 pessoas, e sua sala principal, chamada de Grand Ballroom, tem $1.024 \mathrm{~m}^{2}$ e um pé direito com 7 metros de altura, como mostra a ilustração 11. Neste caso específico, observa-se que o nome da sala principal (Grand Ballroom) se utiliza de parte da marca do hotel (Grand) para reforçar a ideia de grandeza. O mesmo acontece com o maior restaurante do hotel, chamado de Grand Caffé.

\section{Ilustração 11: Centro de convenções}

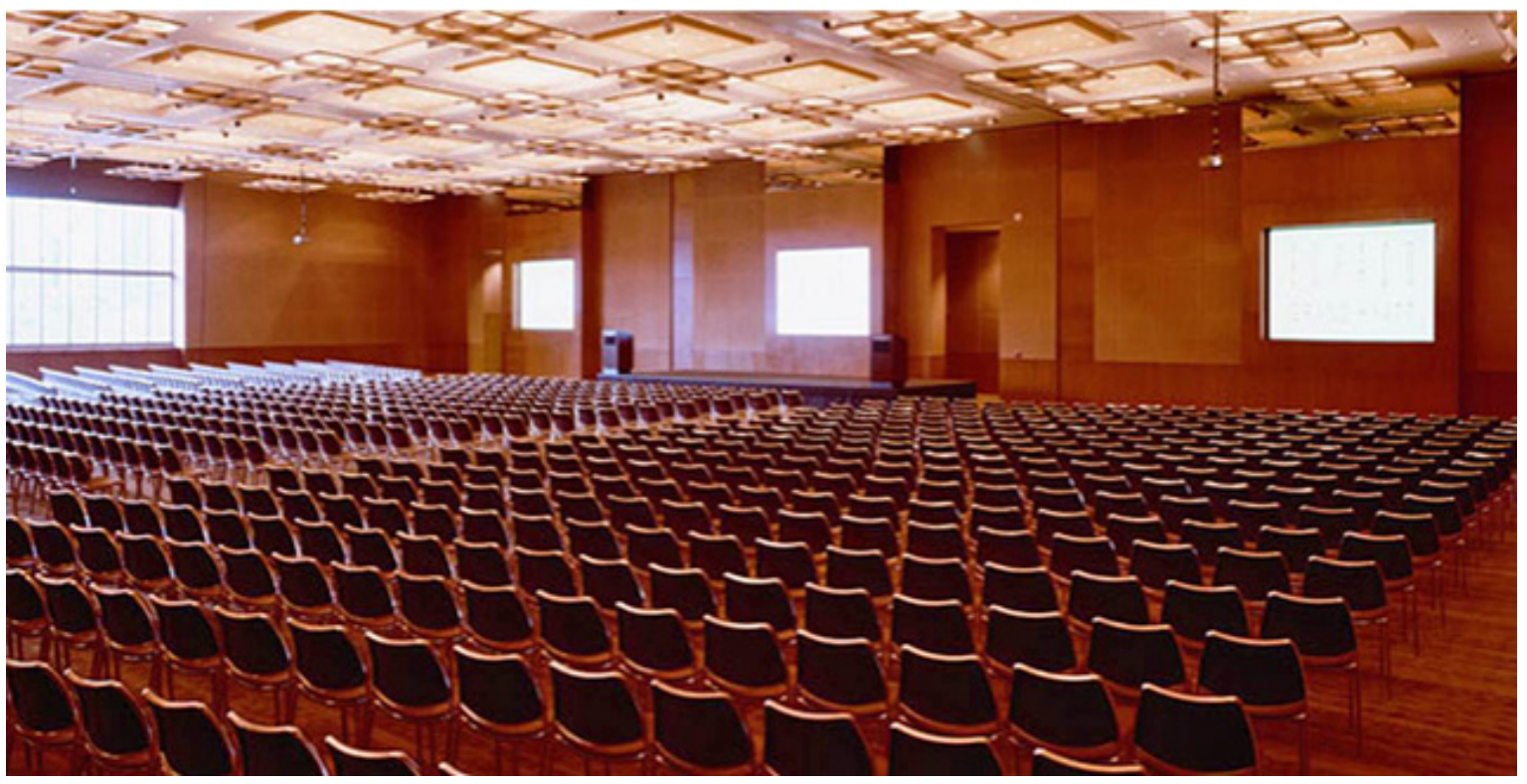

Fonte: HYATT SÃO PAULO, 2011

Outro exemplo deste conceito de grandiosidade é visto na piscina externa, que é uma das maiores piscinas em hotéis da cidade, e que conta com jardins e solarium, como demonstrado na ilustração 12 . 


\section{Ilustração 12: Piscina externa}

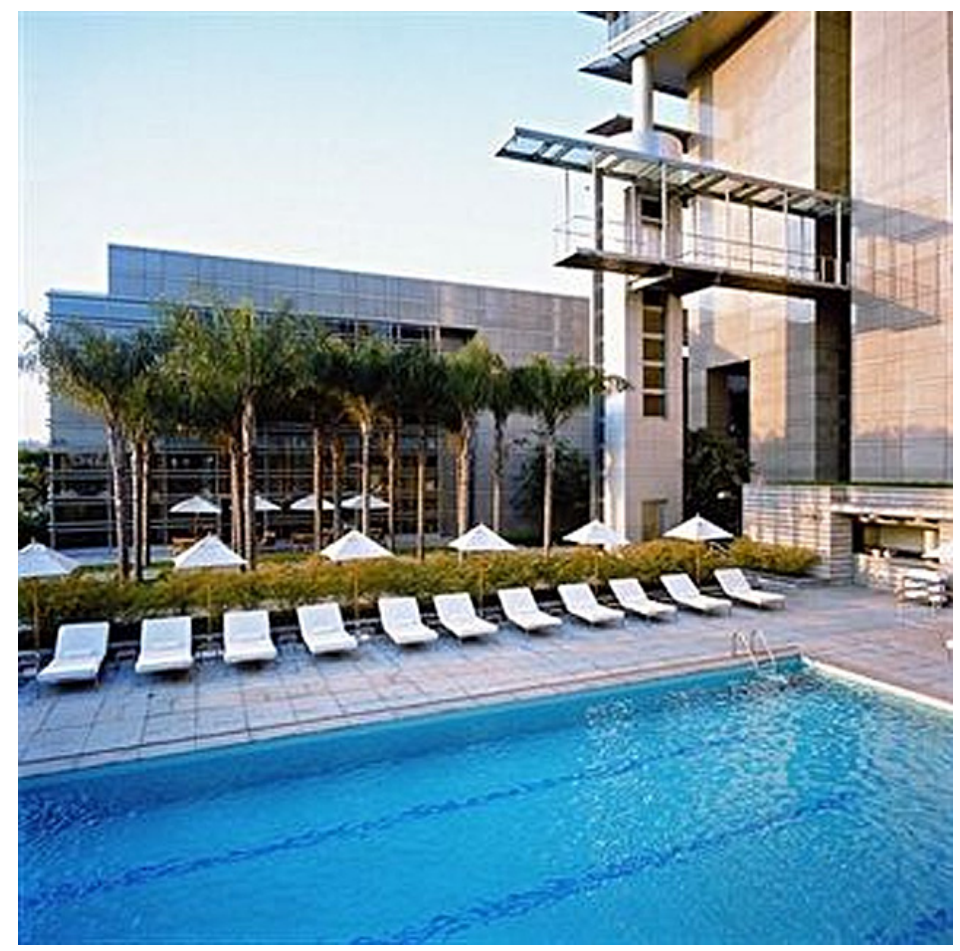

Fonte: HYATT SÃO PAULO, 2011

O mesmo conceito é adotado pelo bar Upstairs, como mostra a ilustração 13, onde se destaca um pé direito duplo, com grande distância entre as mesas, o que também reforça a imagem de generosidade nos espaços.

Ilustração 13: Bar Upstairs Lounge

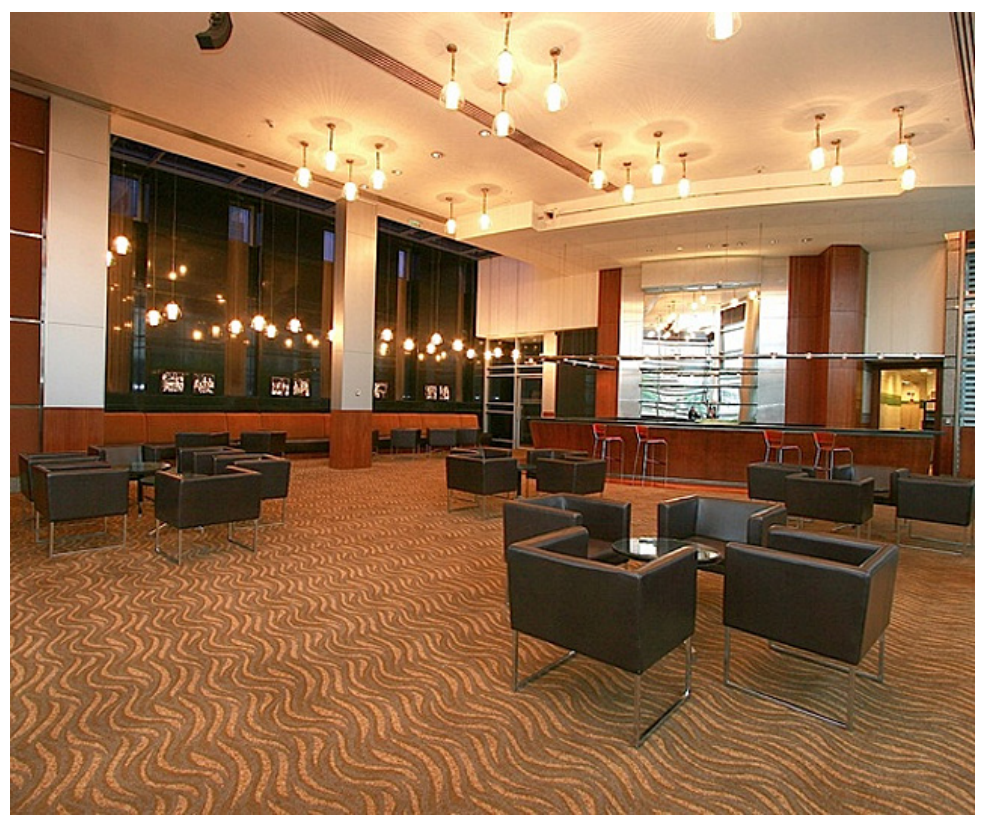

Fonte: HYATT SÃO PAULO, 2011 
Se em termos de concepção arquitetônica do edifício não existe um padrão para o Hyatt, dentro dos apartamentos acontece o oposto. Como já demostrado, um dos conceitos da marca Grand Hyatt é a grandiosidade.

Nos apartamentos isto fica claro, já que estes tem $41 \mathrm{~m}^{2}$, sendo um pouco maior que a média da categoria. Na ilustração 14, além de uma ideia do tamanho do quarto, nota-se outra característica do Hyatt em relação ao seu visual - as janelas são generosas, o que proporciona muita luz natural, além de ampliar a percepção de tamanho e reforçar a vista panorâmica, que é colocada como uma das características oferecidas pelo hotel.

\section{Ilustração 14: Quarto}

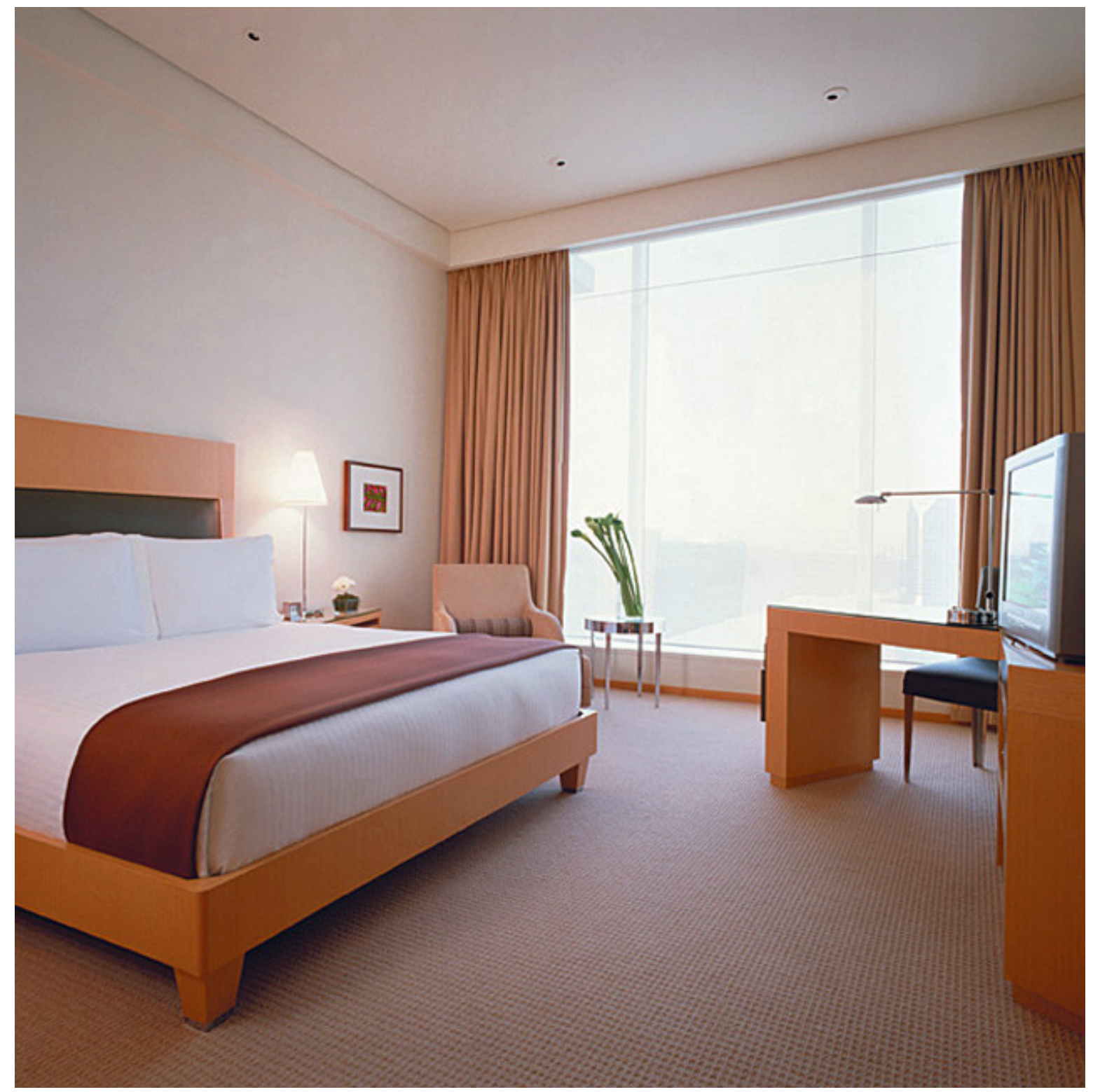

Fonte: foto fornecida pelo hotel 
Em termos de decoração, o Grand Hyatt São Paulo é, como já mencionado, bastante clean. Além do já citado intenso uso de madeira, vidro e concreto, o hotel tem muita luz natural, inclusive nos corredores dos andares, que tem janelas grandes, ampliando a noção de espaço.

A luz natural também é destaque em algumas áreas sociais, como mostra a ilustração 15, destacando a área externa do bar Upstairs Lounge, com cobertura em vidro. Com relação à decoração, nota-se que apesar dos móveis serem diferentes daqueles usados internamente, há uma harmonia visual seguindo o conceito de design moderno, amplo e clean.

\section{Ilustração 15: Área externa do bar Upstairs Lounge}

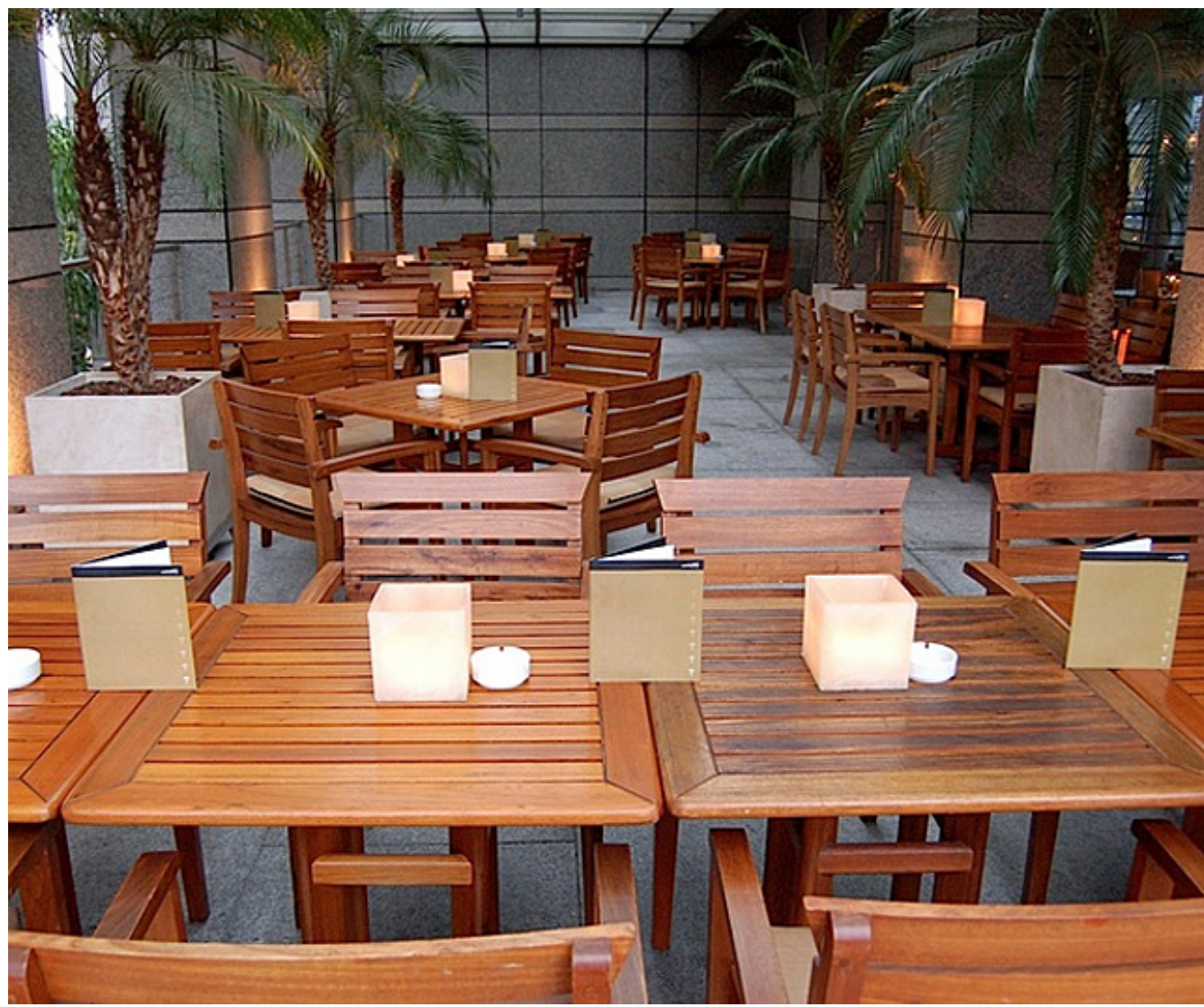

Fonte: HYATT SÃO PAULO, 2011

A iluminação natural através de janelas panorâmicas também está presente no restaurante Kinu, como mostra a ilustração 16. Aqui também é interessante notar que, apesar deste ser um restaurante japonês, tem poucos elementos de decoração que remetem ao design nipônico, fugindo da proposta de tematização dos ambientes feita por Pine e Gilmore. Ao contrário, o conceito de modernidade se faz presente com a arquitetura, que utiliza madeira, vidro e concreto. 
A ideia de fugir da tradicional decoração de restaurantes japoneses, e seguir mais de perto a concepção visual do hotel fica também evidente em detalhes como o apresentado na ilustração 17, que mostra uma bandeja com diferentes copos também do restaurante Kinu. Como pode ser visto, cada copo tem um design, uma cor e um tamanho diferente, e nenhum deles remete ao design normalmente visto em um restaurante japonês.

\section{Ilustração 16: Restaurante Kinu}

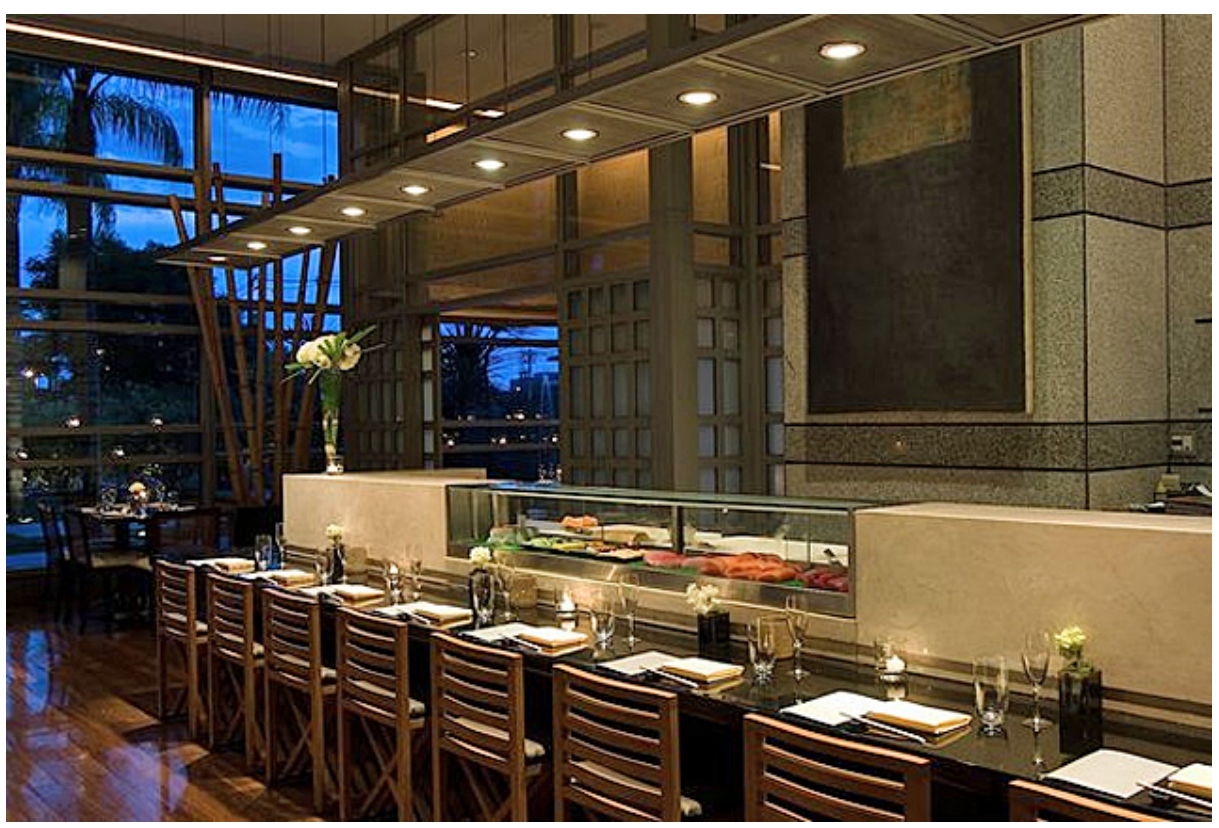

Fonte: HYATT SÃO PAULO, 2011

\section{Ilustração 17: Bandeja - Restaurante Kinu}

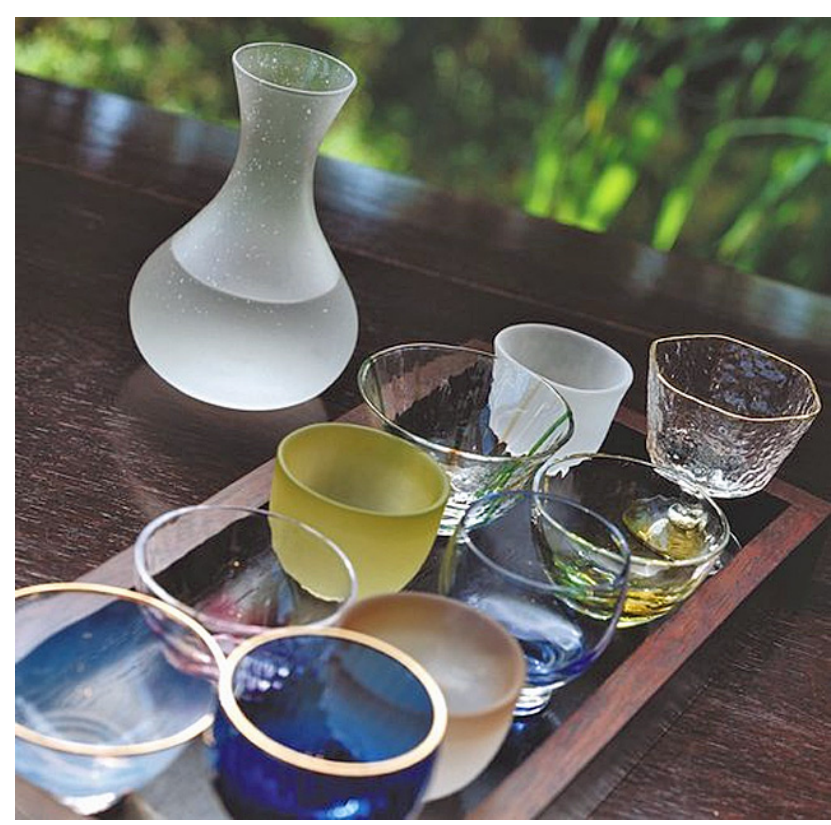

Fonte: HYATT SÃO PAULO, 2011 
A concepção visual em relação aos funcionários segue um padrão, chamado de blooming, que é bastante restrito e bem definido. Este padrão exige que todos os funcionários trabalhem de uniforme, que variam em função dos departamentos, cargos e funções desempenhados, mas que denotam uma sobriedade muito grande, a começar pela sua tonalidade, geralmente escura.

No manual dos funcionários existem as recomendações tradicionais: homens devem usar cabelo curto, sem barba, e não podem usar brinco, nem tampouco tatuagem e/ou piercing em lugar visível. Para as mulheres, a recomendação é que o cabelo não pode cair no rosto, os brincos e colares devem ser discretos e as unhas não podem ser coloridas. Este padrão visual é adotado para toda a cadeia Hyatt.

\section{Olfato}

O Hyatt tem 2 aromatizadores de ambiente: nos apartamentos e corredores é utilizado um aroma de capim santo, o que está de acordo com a ideia de se utilizar produtos com características mais locais. Por isso, de acordo com Faber (2011), esse aroma foi desenvolvido aqui no Brasil, e o objetivo é fazer o hóspede ter uma memória olfativa do hotel.

No spa é utilizado um aroma diferente, à base de gengibre. Nas áreas comuns, no entanto, não é utilizado nenhum aroma.

Outra preocupação com o olfato pode ser visto nas amenities, que são fornecidas pela empresa Granado. Não são produtos exclusivos - apenas a embalagem é personalizada para o hotel. O aroma destes produtos é feito à base de castanha do Brasil, remetendo a produtos locais. É importante mencionar que a Granado é uma marca de produtos de higiene pessoal reconhecida como de boa qualidade, o que reforça a imagem do hotel.

O hotel também oferece um menu de sabonetes, onde o hóspede pode escolher diferentes aromas para os sabonetes que ficarão no seu quarto.

Além das amenities, a empresa Granado fornece os produtos usados no spa. Há uma loja no lobby do hotel, caso os hóspedes queiram comprar algum produto cosmético. Nesta loja, os hóspedes podem encontrar os produtos com os aromas usados pelo hotel. 
Para os funcionários, a recomendação é apenas para que se use o bom senso evitando aromas muito fortes, com exceção das pessoas que trabalham na área de alimentos \& bebidas, que não podem usar nenhum tipo de perfume.

\section{Tato}

Em relação ao tato, existem poucas ações mais específicas, sendo que a maior parte obedece a certo padrão do segmento que é um cuidado bastante grande com o enxoval.

No caso do Hyatt, os lençóis são feitos de algodão de 600 fios. As toalhas devem ser macias, e o hotel oferece 2 tipos de roupão: um atoalhado, mais pesado, e outro de piquê, mais leve e mais macio.

As camas do Hyatt são usadas em todos os hotéis da rede. São camas exclusivas e registradas, e os colchões são produzidos com exclusividade pela empresa Serta, seguindo determinadas especificações.

Nos Estados Unidos, os clientes tem a possibilidade de comprar a "cama Hyatt". Segundo Schramm (2011) o objetivo é que os hóspedes "possam ter no hotel a mesma experiência de conforto que tem em sua casa."

Esta cama, junto com os travesseiros feitos com penas de ganso, e arrumadas de maneira a passar a imagem de conforto e firmeza, pode ser vista na ilustração 18. 


\section{Ilustração 18: Cama Hyatt}

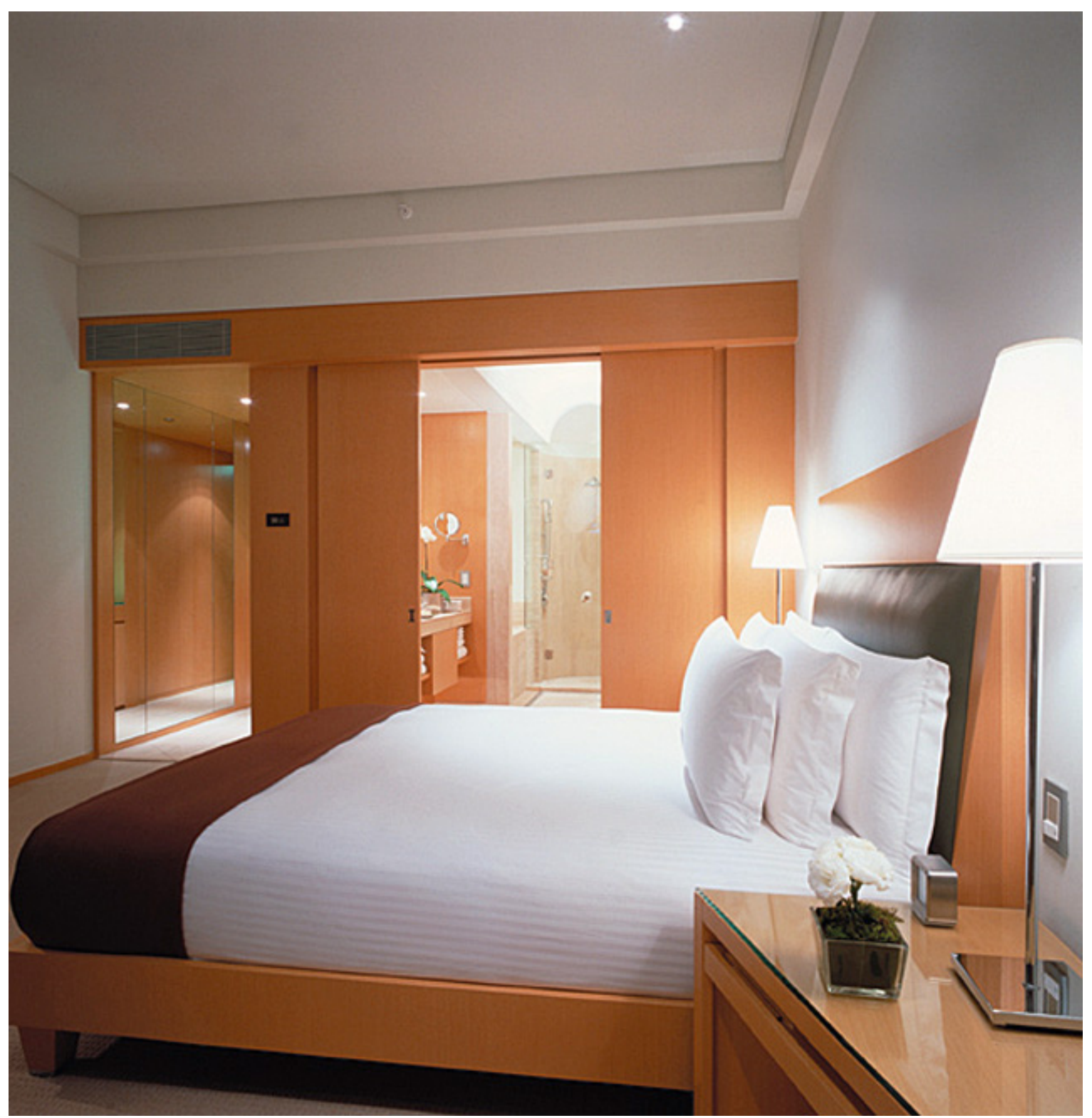

Fonte: foto fornecida pelo hotel

A área de banho apresenta toalhas, roupões e chinelos feitos com tecidos macios e confortáveis, e que também apresentam harmonia visual, como vemos na ilustração 19. A roupa de banho na cor branca é importante para a imagem de limpeza que deve estar presente num hotel desta categoria, além de ser também uma cor neutra, normalmente bem aceita para este tipo de material. 


\section{Ilustração 19: Detalhe da área de banho}

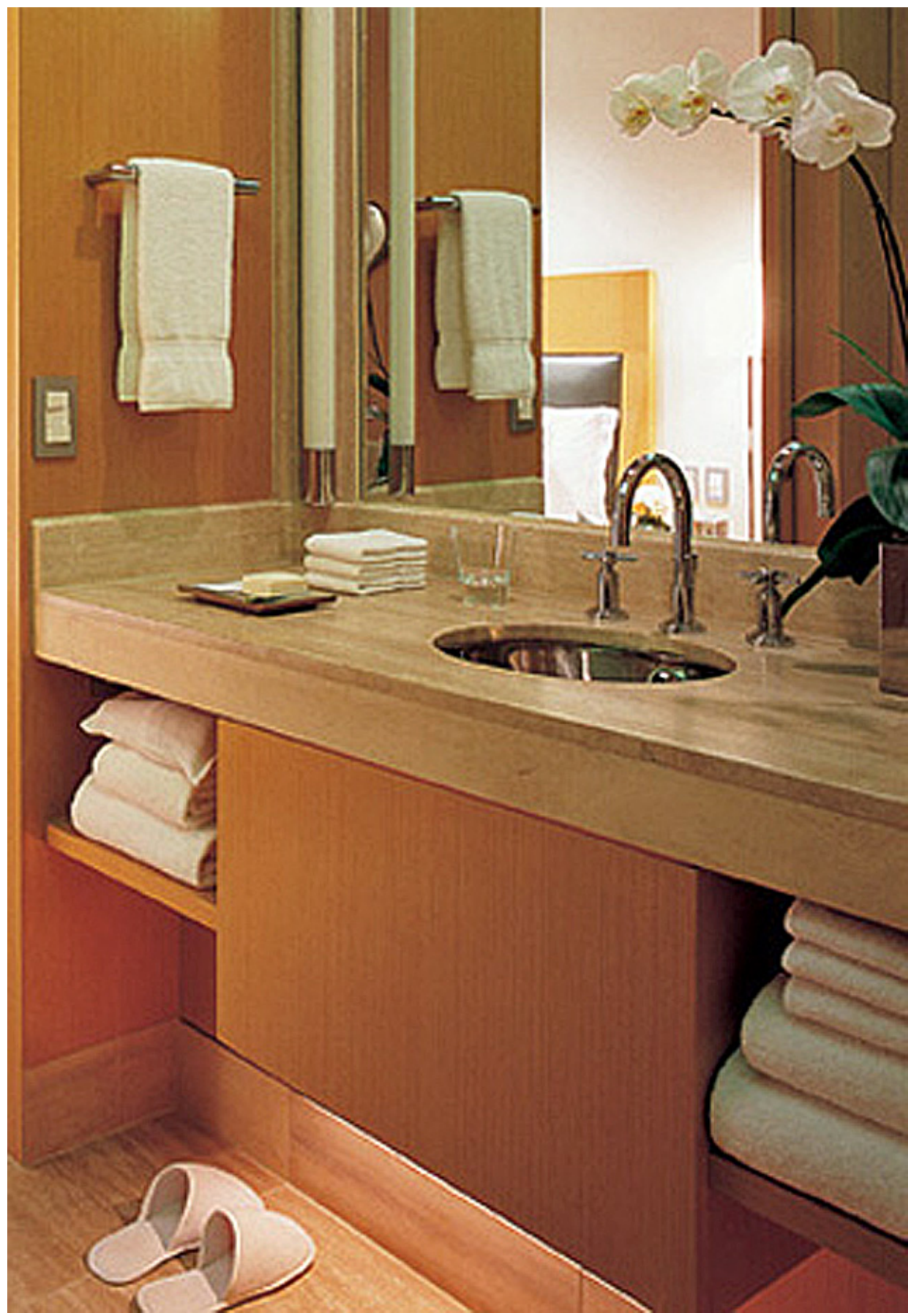

Fonte: foto fornecida pelo hotel

Também na área de banho devem ser destacados dois itens importantes em relação ao tato. $\mathrm{O}$ chuveiro, que não apenas é separado da banheira (o que agrega valor para muitos hóspedes), mas que oferece um banho em forma de ducha. Além disso, o piso do box, feito com material antiderrapante, dá mais segurança na hora do banho, principalmente para pessoas com dificuldades motoras e/ou de idade mais avançada. Isto pode ser visto na ilustração 20. 
Ilustração 20: Box

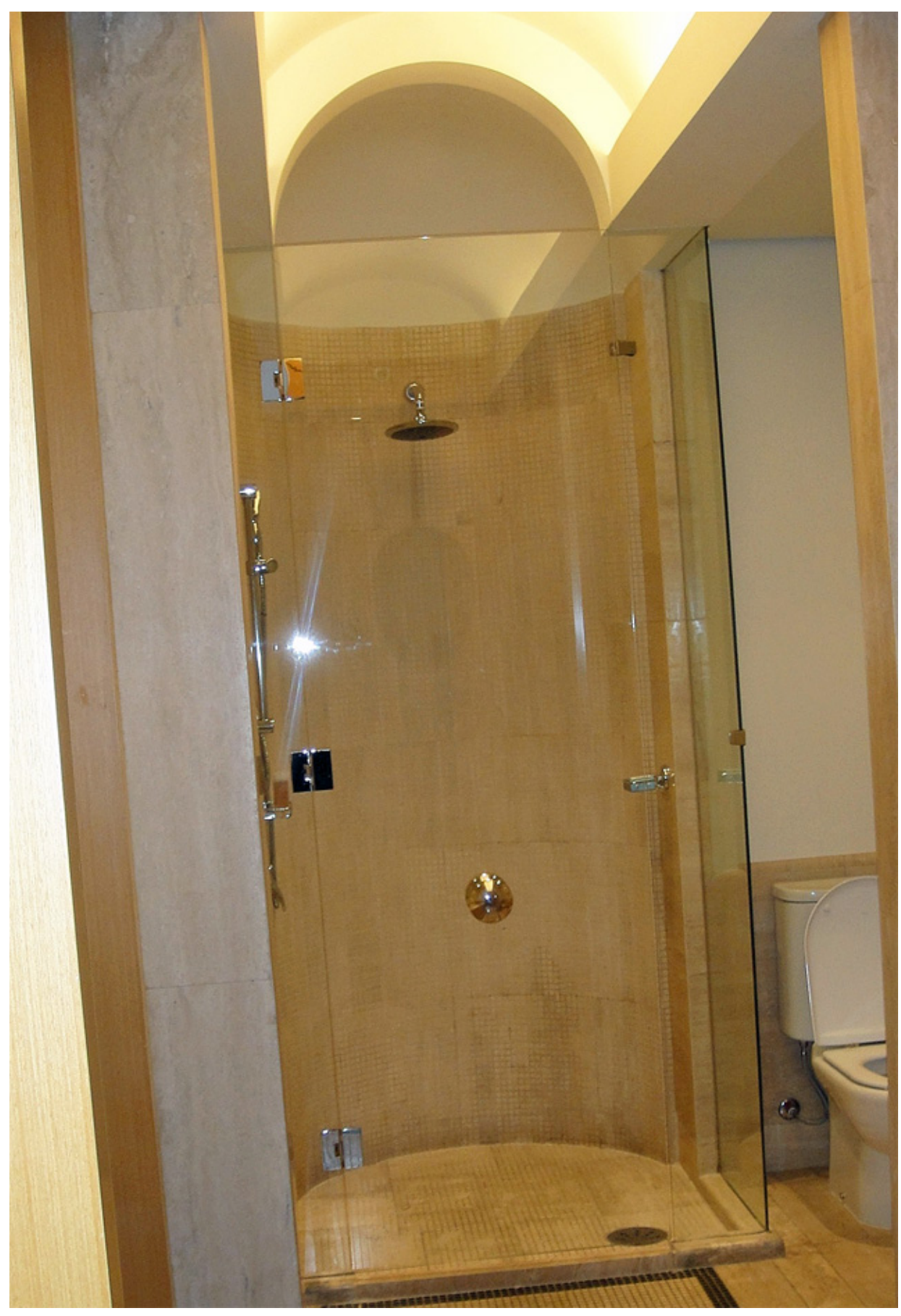

Fonte: HYATT SÃO PAULO, 2011

Na questão do tato foi observado também que a temperatura de todos os ambientes do hotel está sempre regulada em $22^{\circ} \mathrm{C}$.

Outro ponto a ser destacado é a piscina indoor, climatizada, localizada na área do spa, e que conta com raia para natação, como visto na ilustração 21 . 


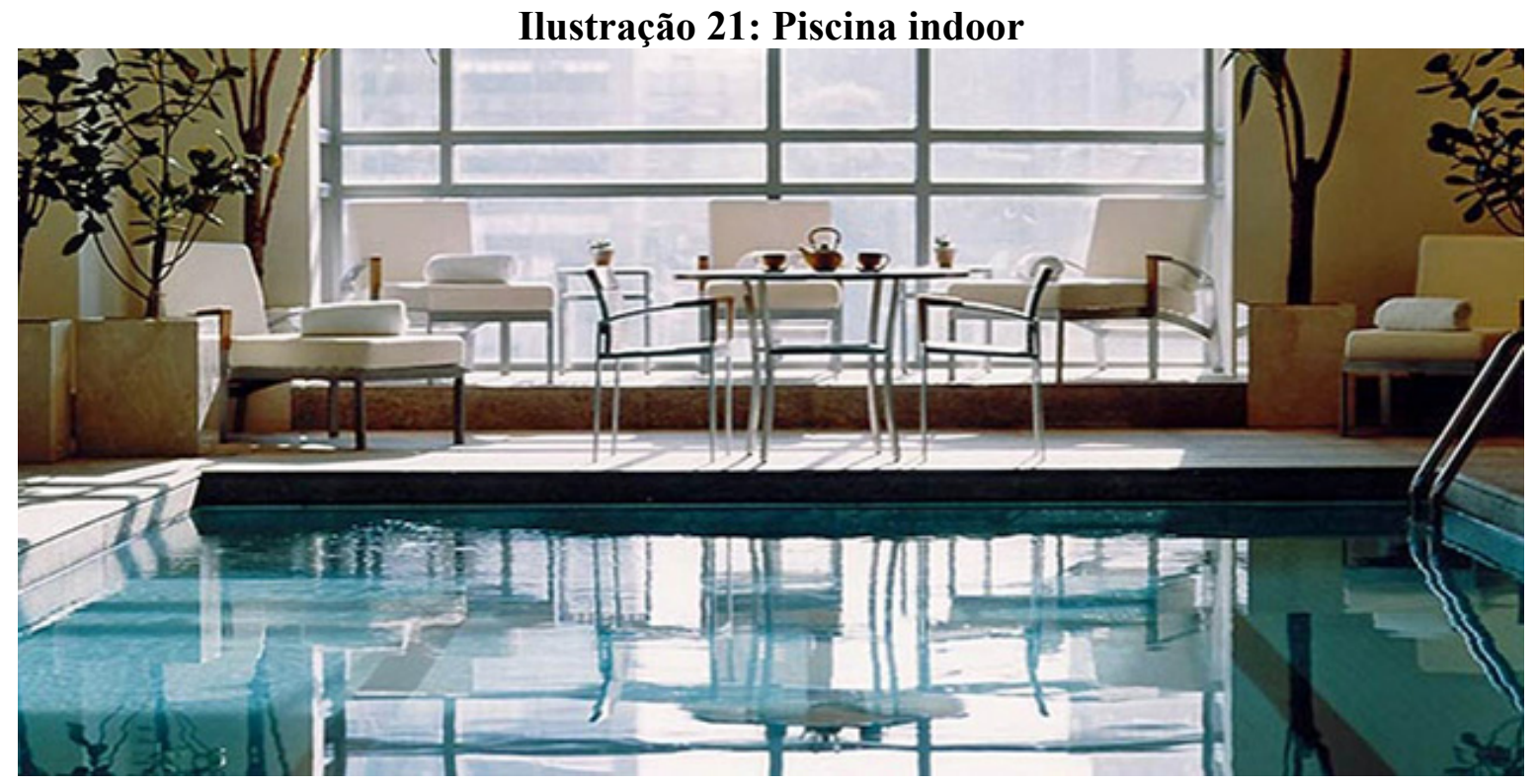

Fonte: HYATT SÃO PAULO, 2011

Por fim, a questão do tato pode ser complementada com alguns dos exemplos mostrados no item "Visão", com destaque para muitos exemplos de cadeiras e poltronas feitas com materiais e design bastante confortáveis.

Ou seja, na questão do tato, pode ser dito que a ideia básica do Grand Hyatt é oferecer ao hóspede a sensação de conforto, mas sem que isso seja ampliado para a ideia de aconchego, o que iria contra o conceito de grandiosidade trabalhado pela marca Grand Hyatt.

\section{Paladar}

A questão do paladar é destacada pelo Hyatt em função do diferencial oferecido pelos 3 restaurantes. É interessante notar que, apesar dos restaurantes serem especializados em culinária japonesa, italiana e francesa, todos tem a preocupação de incluir nos cardápios alguns ingredientes tipicamente brasileiros. Nota-se o uso de frutas nacionais para a elaboração de alguns molhos que acompanham os pratos.

Para exemplificar isso, a ilustração 22 traz o cardápio do restaurante Eau, onde são vistos pratos como sopa de abóbora com queijo Minas, e sorvete de café carioca. 


\section{Ilustração 22: Site restaurante Eau}

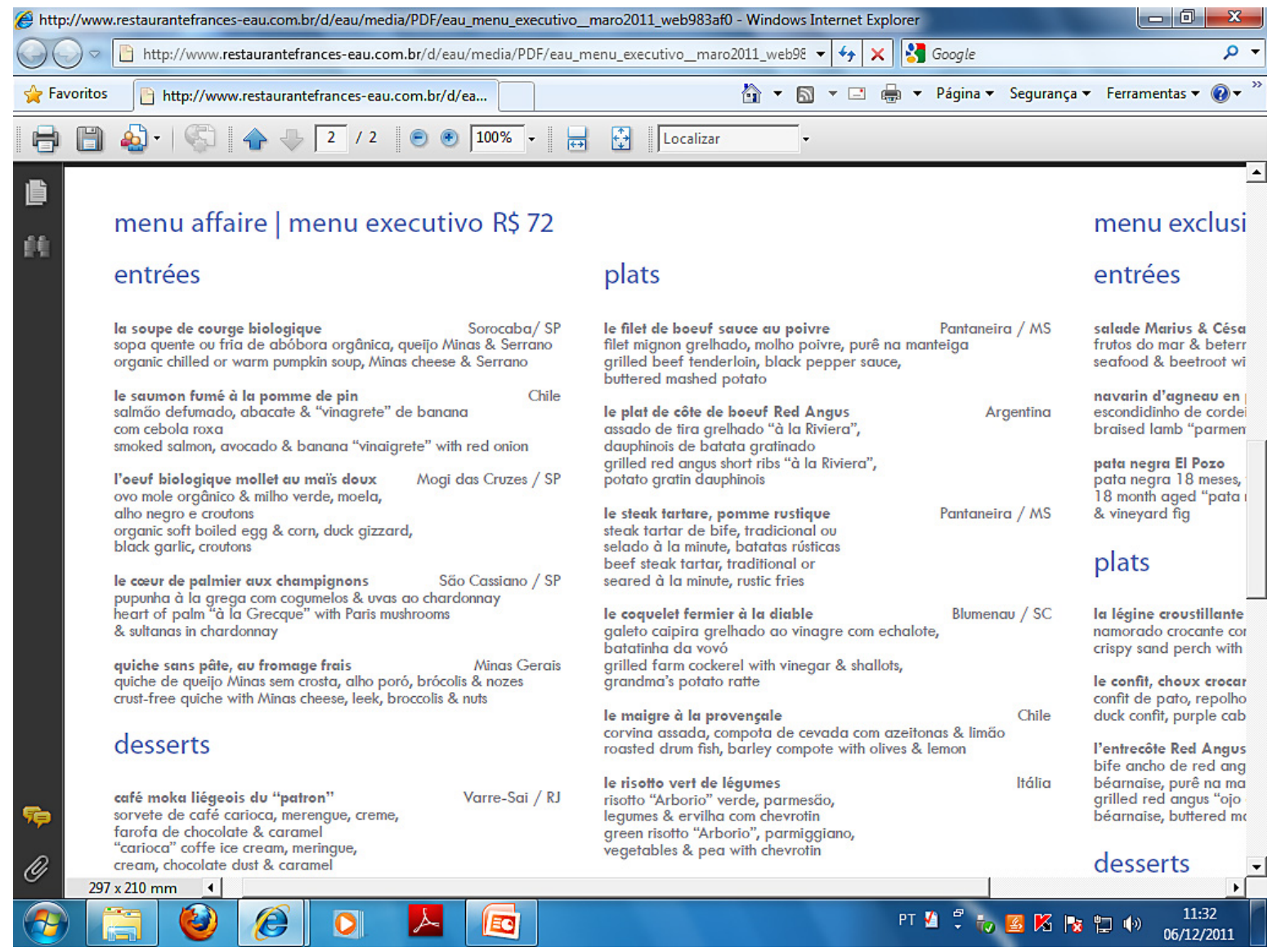

Fonte: HYATT SÃO PAULO, 2011

No caso do frigobar existente nos apartamentos, o Hyatt segue um padrão internacional para os itens que o compõem. Este padrão Hyatt também inclui, além dos produtos tradicionais, alguns itens brasileiros, como é o caso do refrigerante guaraná, e de castanhas de caju.

Para hóspedes vips, é oferecido como boas vindas um prato de frutas brasileiras, contendo caju, jabuticaba e fruta do conde. Segundo SCHRAMM (2011) "o objetivo é oferecer não apenas algo saboroso, mas também que seja bonito em termos de apresentação. Esse cuidado vai até a própria cerâmica do prato e a forma como as frutas são colocadas.”.

Em outras ocasiões, as boas vindas são feitas com o oferecimento de uma garrafa de champanhe e uma caixa de chocolates, conforme pode ser visto ver na ilustração 23. 


\section{Ilustração 23: Kit boas vindas}

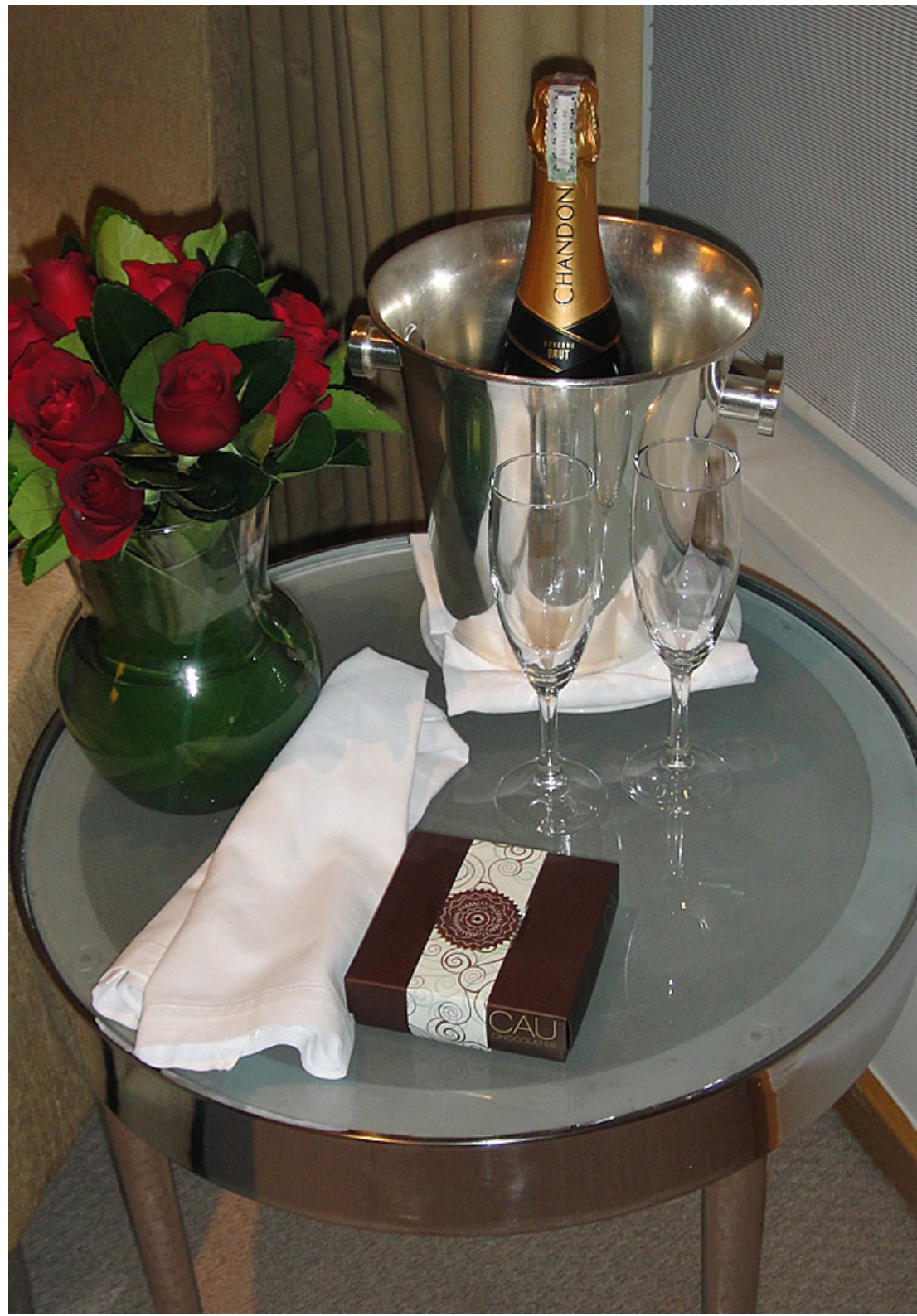

Fonte: HYATT SÃO PAULO, 2011

Como já citado, outra ação que estimula o paladar, são as promoções feitas pelos restaurantes, com os cardápios exclusivos, harmonização de vinhos e eventos gastronômicos.

Como parte do programa "Random Acts of Generosity", o Hyatt tem uma série de produtos que podem ser colocados nos quartos, como brinde de boas vindas, ou outras lembranças, que variam em função do tempo de estadia do hóspede e do tipo de quarto reservado. Dentre estes brindes podem ser citados alguns doces e bolos que são enviados para os quartos usando ingredientes também brasileiros, como é o caso da mandioca. 
Um ponto bastante importante é a preocupação de se aguçar o paladar a partir de uma preocupação com a questão estética na arrumação dos pratos e das mesas. Esta preocupação é vista nas ilustrações 24 e 25 que destacam, respectivamente, um buffet de café da manhã, e a mesa de aperitivos do bar Upstairs Lounge.

No buffet de café da manhã há um padrão estético nas louças utilizadas que, por serem brancas e destacarem as cores dos alimentos, criam um visual mais descontraído e alegre logo pela manhã.

No caso da mesa de aperitivos, há também a mesma preocupação com a arrumação de todos os pratos, com o detalhe de que os próprios alimentos acabam servindo de elemento decorativo.

\section{Ilustração 24: Buffet de café da manhã}

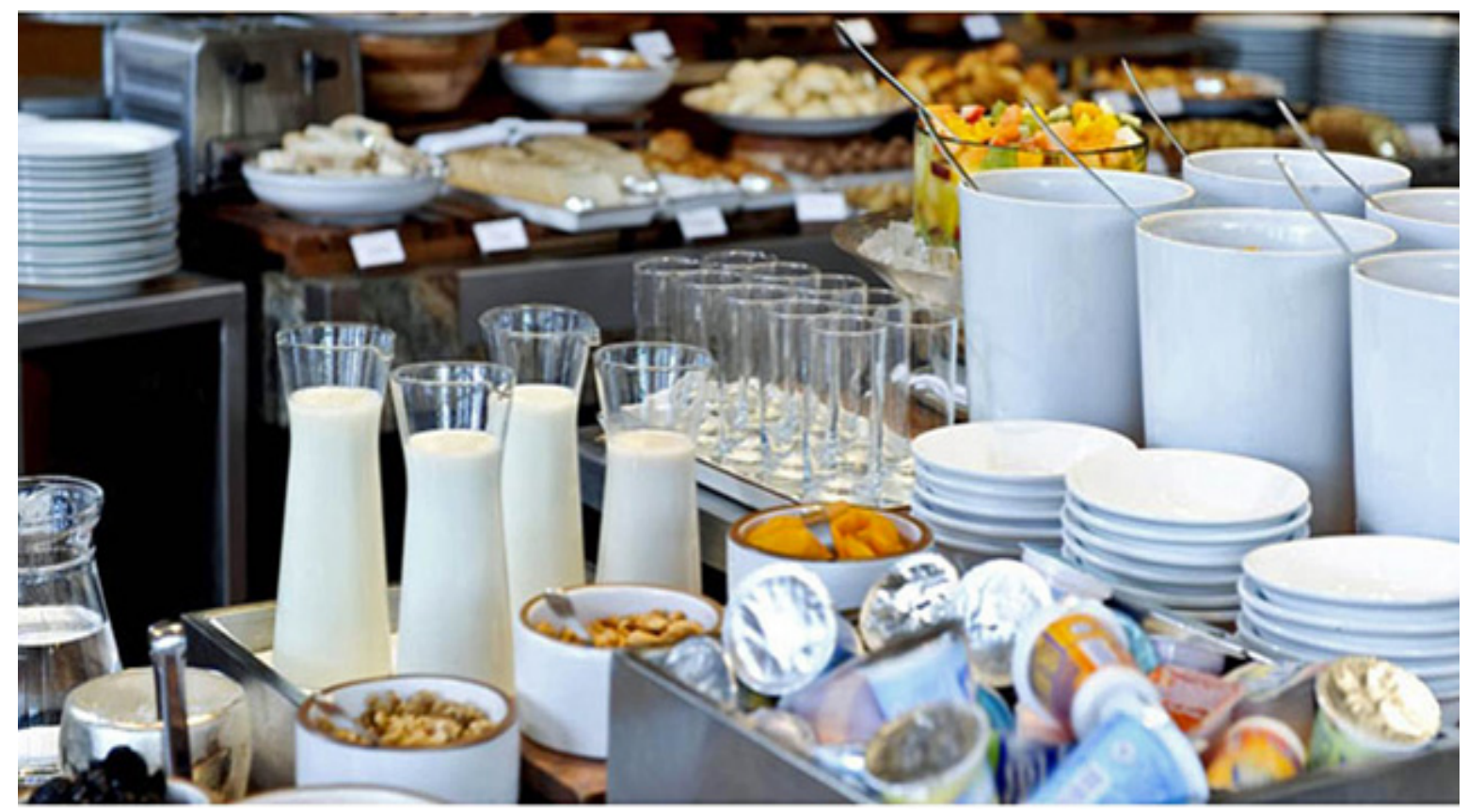

Fonte: HYATT SÃO PAULO, 2011 
Ilustração 25: Buffet de aperitivos do bar Upstairs Lounge

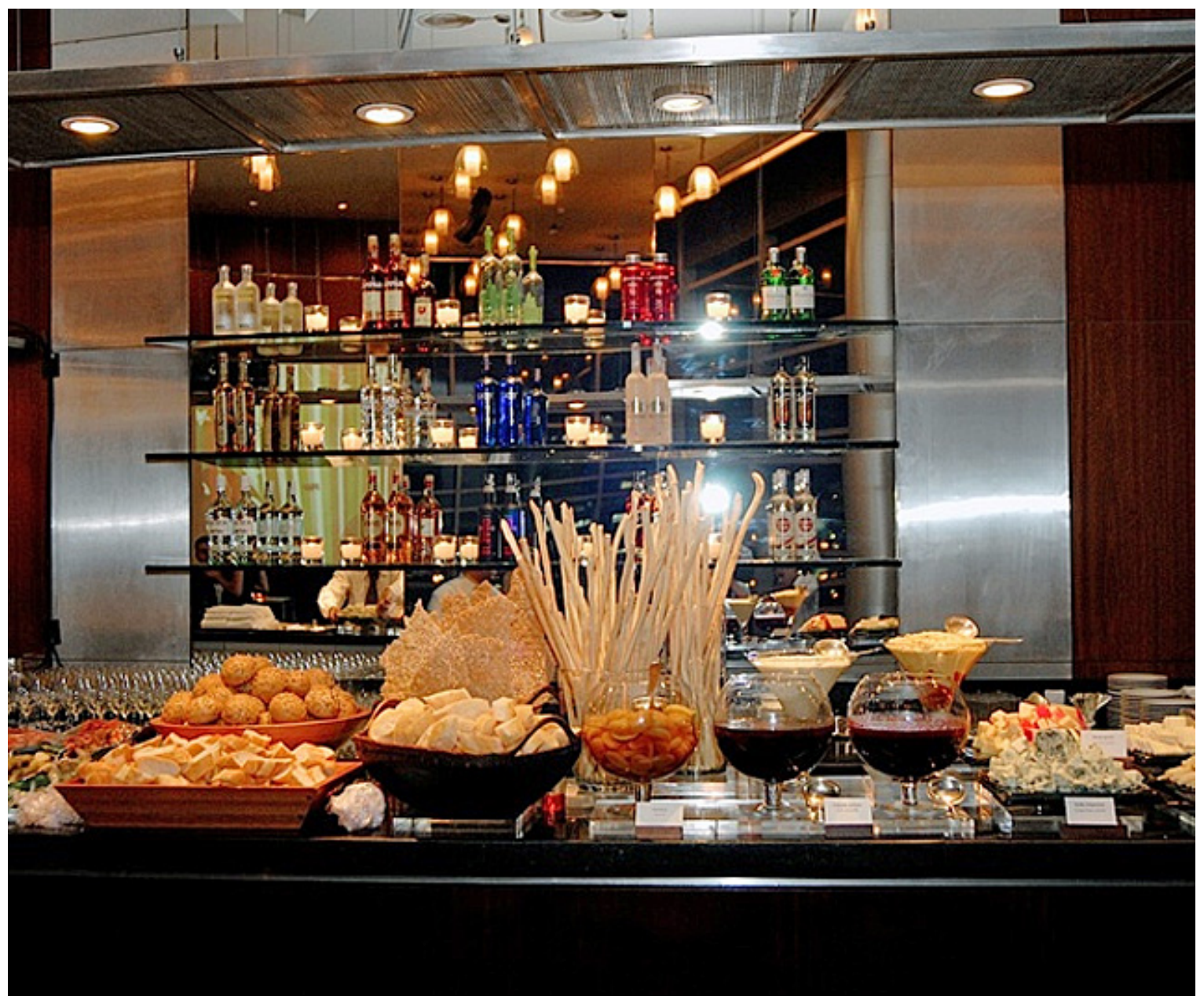

Fonte: HYATT SÃO PAULO, 2011

A preocupação em se estimular o sentido do paladar a partir do seu aspecto visual não fica restrita à decoração dos pratos e mesas dos restaurantes. Sendo a área de alimentos e bebidas um dos serviços ofertados pelo hotel, é bastante adequado que os materiais de comunicação de marketing também destaquem esses apelos.

Por isso, parece ser acertada a exploração dos aspectos visuais dos bares e restaurantes no site do hotel. Como visto nas ilustrações 26 e 27, a home page do bar Upstairs, bem como uma das áreas do site Restaurante Eau destacam várias fotos dos pratos ali servidos. É fácil perceber a preocupação em se provocar o apetite appeal com base nestas imagens.

Aqui também fica clara a preocupação em se explorar mais de um elemento sensorial nos serviços ofertados pelo hotel. 
Ilustração 26: Site do bar Upstairs

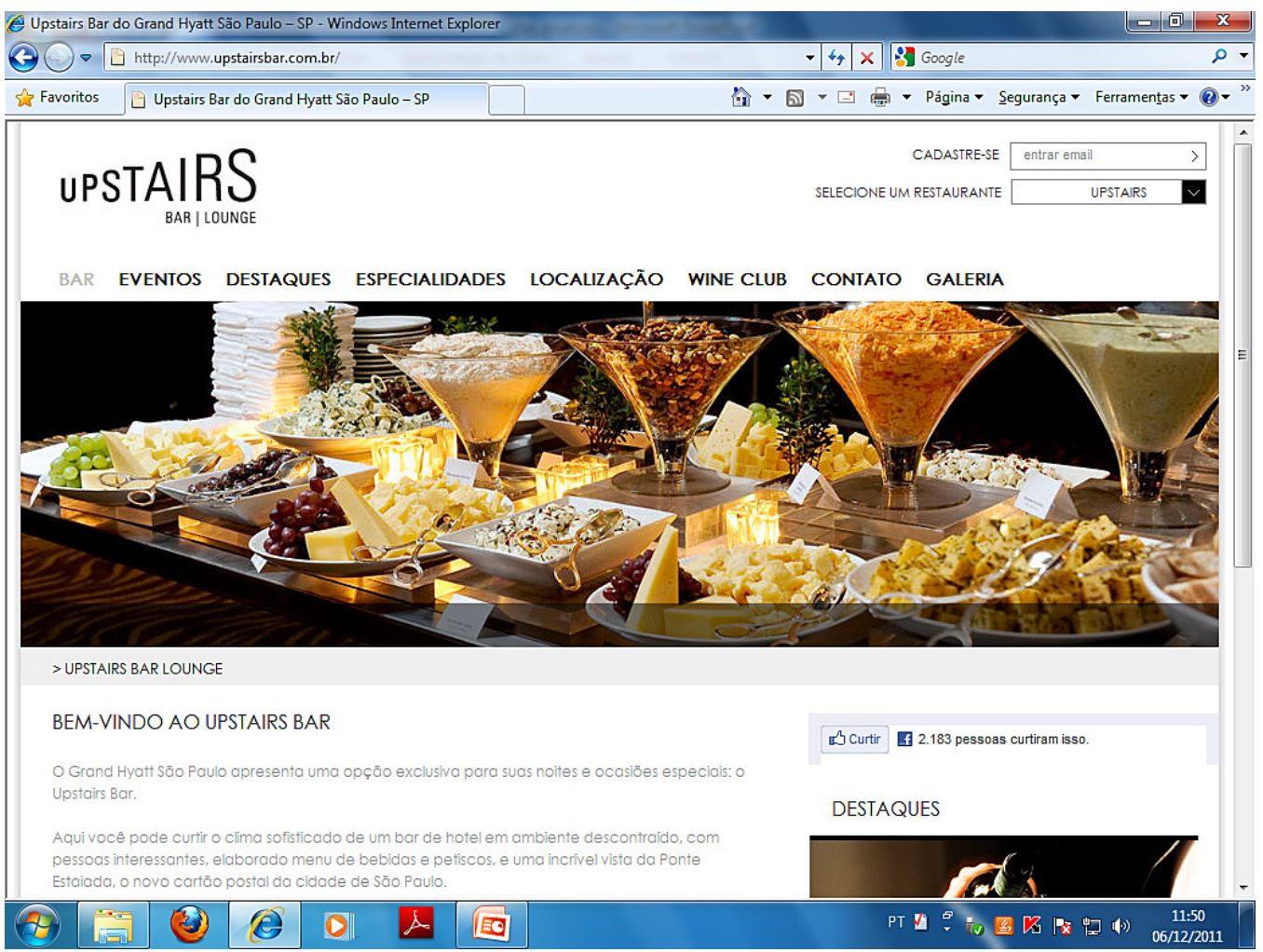

Fonte: HYATT SÃO PAULO, 2011

Ilustração 27: Site do restaurante Eau

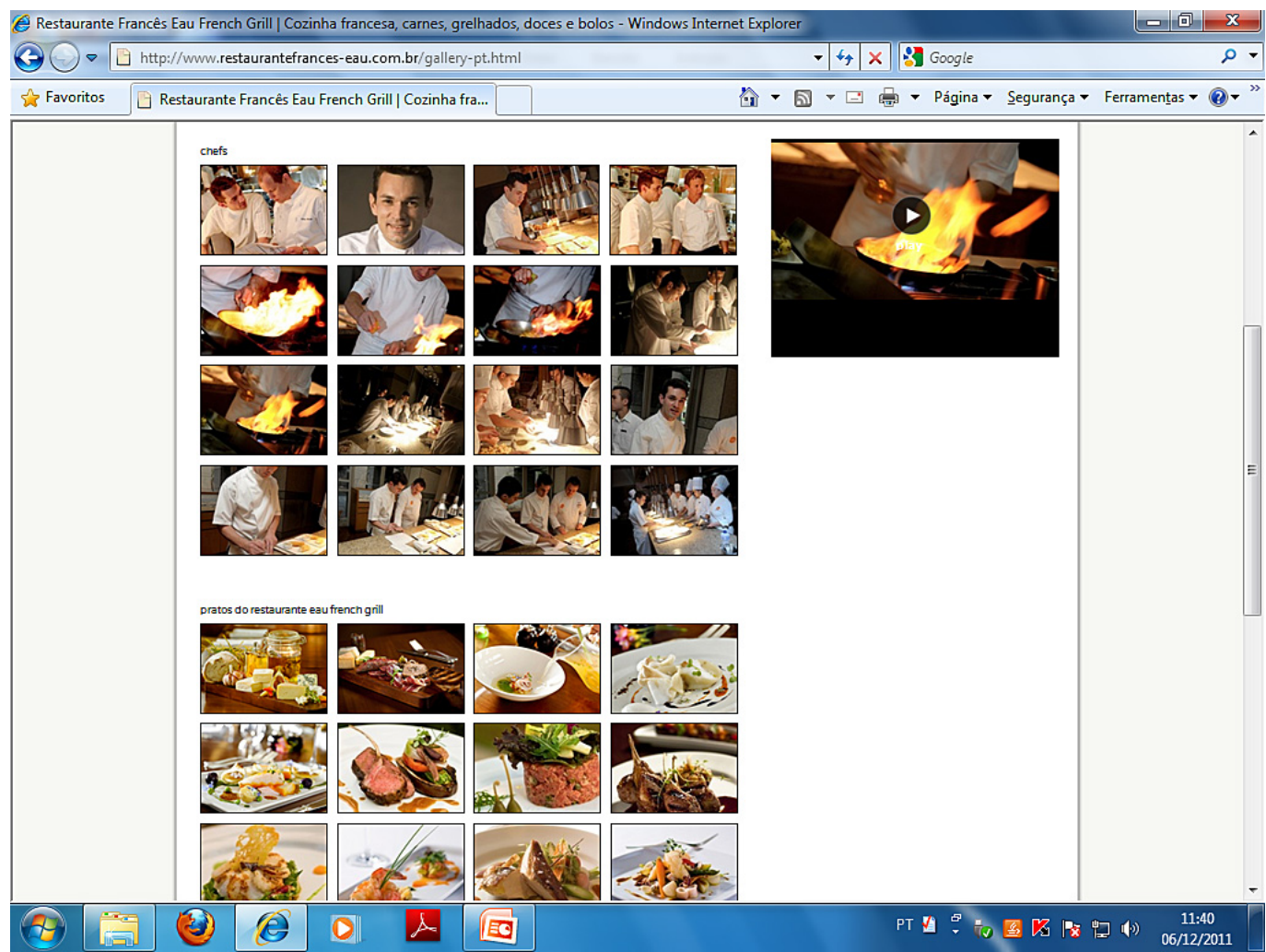

Fonte: HYATT SÃO PAULO, 2011 
Por fim, também merece destaque na questão do paladar a Wine Library, que é uma grande adega de dois andares, com estrutura feita em aço, com centenas de rótulos de vinhos das mais diversas origens, e que fica localizada entre os restaurantes Eau e Kinu.

Como pode ser observado na ilustração 28, a Wine Library estimula o paladar dos apreciadores de vinho, pois seu próprio design deixa claro uma enorme diversidade de produtos para serem experimentados. A estrutura de aço da Wine Library também combina com os elementos de decoração de outros espaços do hotel, conforme já apresentado, e os seus dois andares ressaltam a ideia de grandiosidade que o hotel procura passar.

Ou seja, aqui também há uma adequação entre o conceito do hotel e algumas das ações desenvolvidas, como o uso de mais de um sentido para um determinado serviço.

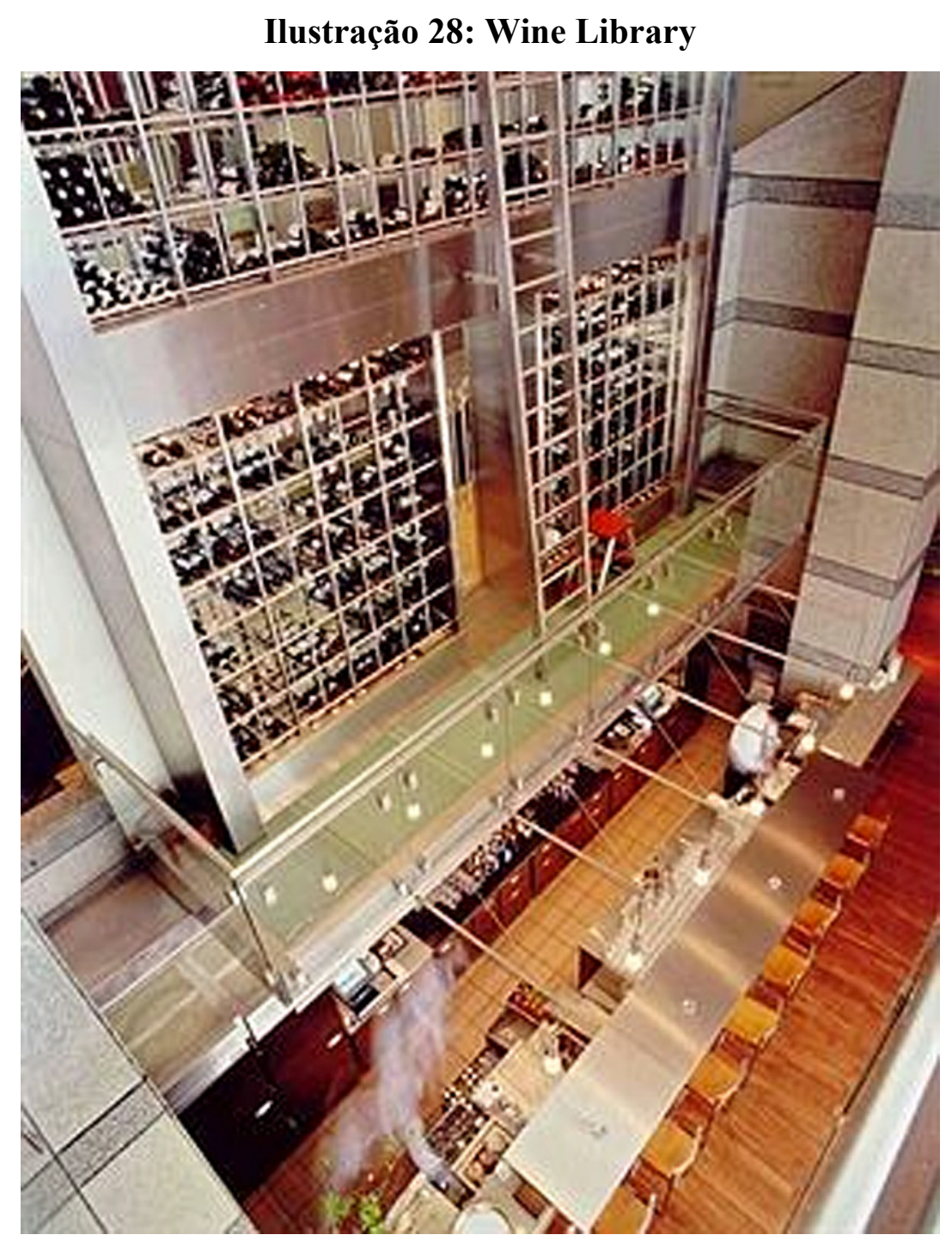

Fonte: HYATT SÃO PAULO, 2011 


\section{Audição}

O sentido da audição é trabalhado pelo hotel Grand Hyatt com algumas poucas ações específicas: em primeiro lugar, existe música ambiente nas áreas comuns do hotel - lobby, corredores e restaurantes. A preocupação maior é com a qualidade das músicas, que devem passar a ideia de refinamento, de delicadeza. Porém, o conceito que o hotel tem de música refinada e delicada é subjetivo, na medida em que não existe nenhum critério mais específico para a seleção musical.

Cada restaurante tem sua própria seleção de músicas que, no entanto, não precisa refletir a culinária oferecida. Isso quer dizer que o restaurante Eau, de cozinha francesa, não tem na sua seleção musical apenas canções francesas. O mesmo acontece com o restaurante Kinu, de culinária japonesa, e o restaurante Grand Caffé, que tem forte influência da cozinha italiana, ou seja, nenhum deles tem na sua lista musical apenas canções japonesas e italianas, respectivamente. Isso reforça a afirmação feita anteriormente de que os restaurantes não são temáticos.

O hotel já fez um Cd com músicas de bossa nova para distribuir como brinde para os hóspedes, especialmente para os estrangeiros. Neste caso, nota-se também aqui a mesma integração em relação ao toque de brasilidade que o hotel se propõe a fazer. Segundo Faber (2011) "sentimos que, principalmente para os hóspedes estrangeiros, o Brasil tem um toque muito bacana. Então, usamos isso de uma maneira positiva, para aumentar esse tipo de experiência. O Brasil é muito musical, então é fácil fazer isso aqui."

Outra preocupação em relação à audição está relacionada com a fala dos funcionários. Segundo SCHRAMM (2011), "existe um script para atendimento telefônico, que segue uma determinada etiqueta. E existe também uma fala obrigatória, que virou marca registrada no hotel: cada vez que alguém se dirige a um funcionário e diz "obrigado", o funcionário deve responder "é um prazer". Acaba ficando uma coisa natural, e os clientes acabam escrevendo nas avaliações que "é muito bom ouvir é um prazer"." 


\subsubsection{Resumo das Ações Sensoriais}

De acordo com a análise feita sobre o Hyatt, podem-se resumir as ações sensoriais desenvolvidas pelo hotel conforme quadro abaixo:

Quadro 2 - Hyatt - Resumo das ações sensoriais

\begin{tabular}{|l|l|l|l|l|l|}
\hline \multicolumn{1}{|c|}{ Pontos de contato } & Visão & Olfato & Tato & Paladar & Audição \\
\hline Apartamentos & & & & & \\
\hline Áreas comuns & & & & & \\
\hline Bares e restaurantes & & & & & \\
\hline Centro de convenções & & & & & \\
\hline Áreas de lazer / esporte & & & & & \\
\hline Pessoas & & & & & \\
\hline Comunicação & & & & & \\
\hline
\end{tabular}

Fonte: elaborado pelo autor

Com base nesta análise, é possível afirmarmos que o hotel Hyatt efetivamente desenvolve algumas ações que exploram as experiências sensoriais dos hóspedes de maneira planejada e pró-ativa. Por outro lado, também fica evidente que muitas das ações desenvolvidas não partiram de um propósito de se explorar com mais força os sentidos dos hóspedes, ou seja, não foram planejadas levando-se em conta o estímulo sensorial como ferramenta de marketing.

O sentido da visão, que é o mais trabalhado, parece ter um propósito de marketing mais definido. Isto fica claro, por exemplo, quando o hotel se posiciona como grandioso e isso é refletido no tamanho dos quartos, lobby, centro de convenções e piscina, por exemplo. É evidente que a ideia de grandiosidade é passada a partir desta concepção visual e arquitetônica e, neste caso, pode-se afirmar que existe uma exploração do sentido como ferramenta de marketing.

Por outro lado, o uniforme dos funcionários e alguns elementos de decoração, apesar de terem motivo claro para aquela concepção visual, não parece que foram concebidos para criar algum tipo de experiência mais expressiva, mas apenas seguem padrões adotados pelo setor, ou seja, são produtos e serviços esperados. 
O mesmo se pode dizer do sentido do olfato. As recomendações para os funcionários também seguem padrões conhecidos na hotelaria de luxo. Por outro lado, a aromatização dos ambientes, feita com aromas brasileiros, seguindo o conceito do hotel em dar um toque local às suas ações, pode ser considerada uma ação de marketing experiencial.

O tato parece ser o sentido menos desenvolvido como ferramenta de marketing. As ações feitas pelo Hyatt também seguem normas já estabelecidas, como um bom enxoval, banho de ducha, colchões confortáveis, etc. O mesmo se pode dizer da piscina indoor que apenas por ser climatizada não pode ser considerada como ação de marketing. Isto também pode ser colocado apenas como um serviço esperado.

O paladar é outro sentido que tem ações interessantes, especialmente no desenvolvimento dos cardápios dos restaurantes, com a inclusão de ingredientes brasileiros nas três culinárias exploradas pelo hotel (japonesa, francesa e italiana).

A extensão dessas ações acabou gerando outras, que também podem ser consideradas experienciais, como é o caso das promoções mais customizadas de degustação de vinhos e menus especiais, além dos bolos e doces feitos com ingredientes brasileiros, que são colocados como brindes nos quartos.

Finalmente, podem-se observar as ações feitas para se explorar o sentido da audição. Especificamente, a criação da expressão "é um prazer" nos parece interessante no sentido de criar uma "marca auditiva" para o hotel. Por outro lado, a existência de música ambiente por si só, mesmo levando-se em conta que foi produzida para o hotel, é outra ação que parece seguir um padrão existente.

Como demonstrado na revisão teórica, qualquer ação é percebida pelos sentidos, ou seja, independente da atitude do hotel, o hóspede vai ter uma experiência. A questão que se coloca é se o hotel vai ou não gerenciar esta experiência.

No caso do Hyatt, entende-se que o hotel está se desenvolvendo nesta área. O posicionamento pretendido parece bastante claro, principalmente na questão de dar um toque brasileiro às ações desenvolvidas (além da exploração do conceito de grandiosidade, que segue a linha da marca Grand Hyatt). 
Por causa disso, muitas das ações seguem este parâmetro de brasilidade, o que facilita no seu desenvolvimento na medida em que o conceito está claro. No entanto, exatamente por causa deste conceito, entende-se que o Hyatt ainda pode desenvolver várias ações para aprimorar a experiência sensorial dos hóspedes.

Se lembrada apenas a diversidade da música e da culinária brasileira, nota-se que existem inúmeras opções para que, pelo menos o sentido da audição e do paladar sejam mais explorados, seguindo o posicionamento pretendido pelo hotel.

Além disso, existe outro ponto que chama a atenção. O conceito de pontos de contato é definido por KOTLER e KELLER (2006, p. 151) como "qualquer ocasião em que o cliente tem contato com a marca ou o produto".

Evidentemente que, numa organização como um hotel, dada às suas próprias características, a quantidade de pontos de contato é extremamente grande, o que faz com que a gestão deste conceito seja mais trabalhosa e, por isso mesmo, exige atenção maior dos gestores.

Se, por um lado, é verdade que o Hyatt ainda pode desenvolver novas ações para explorar os sentidos dos seus hóspedes, também nos parece verdadeiro que a gestão e manutenção daquilo que já é feito deve ser mantida e desenvolvida. E isto nem sempre acontece.

O site do hotel - que é uma das suas maiores ferramentas de comunicação - é um pequeno exemplo disto. Numa das visitas realizadas, foi observado que a atualização do site estava bastante defasada. Como visto na ilustração 29, no dia 06/12/11 a página do restaurante Eau convidava para uma degustação de vinhos que havia ocorrido no dia 22/11/11, ou seja, 14 dias antes. Isto significa que o site estava há, no mínimo, 2 semanas sem atualização, ou então, que este ponto passou despercebido.

Evidentemente que este é um pequeno erro que, por si só, não compromete o trabalho desenvolvido pelo hotel. Por outro lado, também é apenas um exemplo da importância e da complexidade de se administrar todos os pontos de contato para que, ao final, a experiência seja a melhor possível, como promete o hotel. 
Detalhes como este ficam ainda mais evidentes quando se lembra de que um dos objetivos do hotel é aumentar a demanda dos hóspedes de lazer, além de também aumentar a demanda dos seus restaurantes, independente da hospedagem.

\section{Ilustração 29: Site do restaurante Eau}

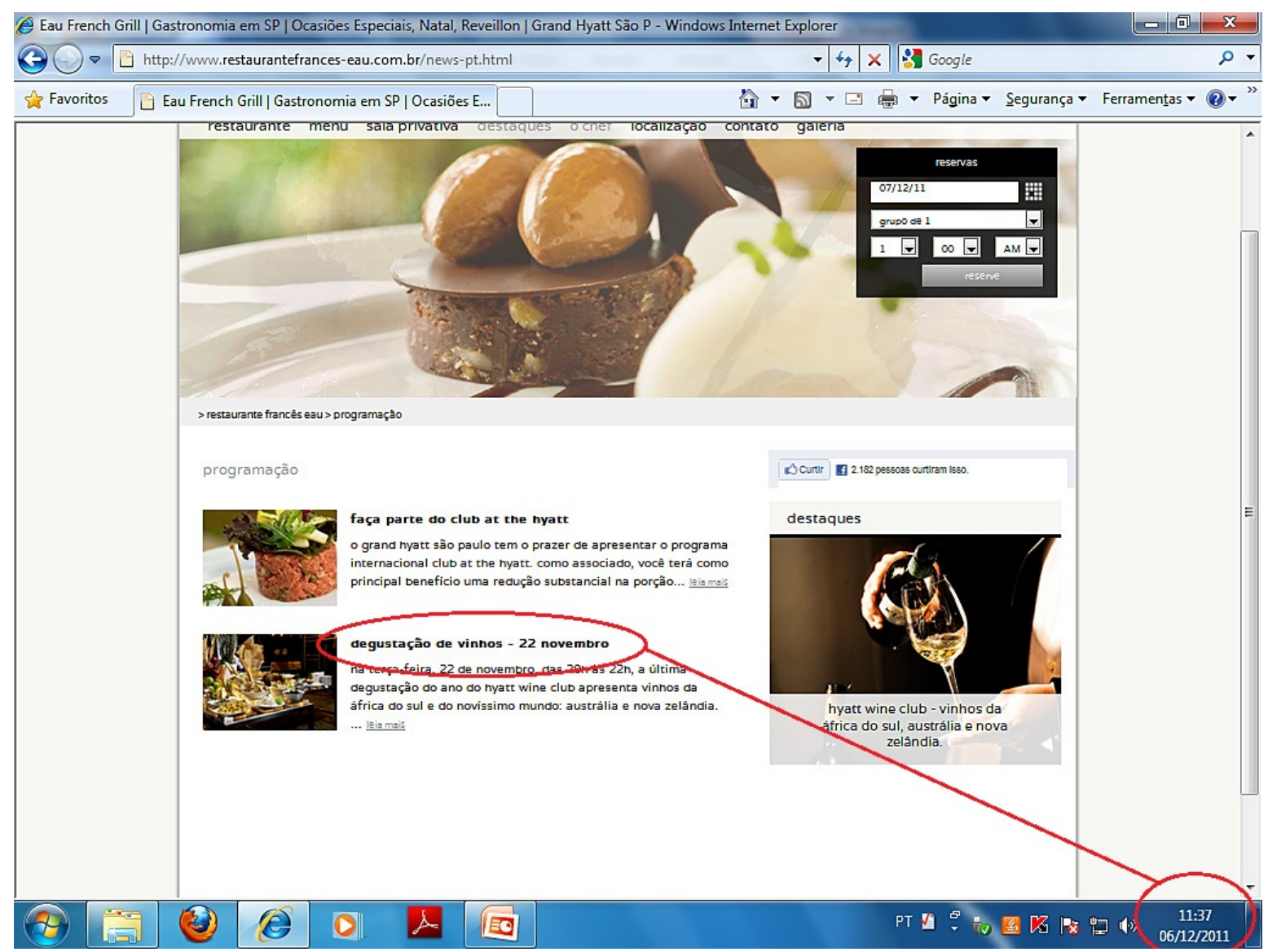

Fonte: HYATT SÃO PAULO, 2011

A conclusão é que, embora no hotel Grand Hyatt ainda existam muitas ações passíveis de serem desenvolvidas, também é fato que algumas ações pontuais são feitas seguindo o conceito do hotel. Isso significa afirmar que o Hyatt efetivamente explora algumas experiências sensoriais como ferramentas de marketing. 


\subsection{Descrição do caso Hilton}

\subsubsection{Fontes de Informações consultadas}

\section{Páginas da internet}

HILTON. Disponível em: < http://www.hiltonworldwide.com >. Primeiro acesso em $04 / 10 / 2011$

TRIP ADVISOR. Disponível em: < www.tripadvisor.com > Primeiro acesso em 09/10/2011.

\section{Entrevistas}

Entrevista com o Sr. Guilherme Castro (CASTRO, 2011), Diretor de Desenvolvimento de Negócios, realizada no dia 18/11/2011, na sede do hotel Hilton.

O Sr. Guilherme Castro é formado em turismo e história, e tem Pós-graduação em marketing de serviços, além de cursos em antropologia do consumo. Trabalha há 11 anos no Hilton. Sua área é responsável por 4 gerências: vendas corporativas, marketing, grupos e eventos e revenue.

\section{Observações}

Observações presenciais realizadas no hotel Hilton nos dias 18/11/2011 e 19/11/2011.

\subsubsection{Informações gerais sobre o hotel}

Em 1919, Conrad Hilton comprou o The Mobley, um hotel localizado em Cisco, Texas. Nos anos seguintes adquiriu mais alguns hotéis no Texas, ampliando seus negócios. Em 1925, inaugurou o Dallas Hilton, o primeiro hotel a levar o nome de Hilton. Como o ar condicionado ainda não tinha sido inventado, o hotel foi construído de forma que os quartos não pegassem sol durante o dia, para que não ficassem muito quentes. Em 1927 foi aberto na cidade de Waco, Texas, o primeiro hotel com água corrente e ar-condicionado nas áreas públicas. 
Em 1943 Conrad comprou dois hotéis na cidade de New York - o Plaza e o Roosevelt tornando-se o primeiro grupo hoteleiro com atuação nas duas costas americanas. Três anos depois, em 1946, foi formado o Hilton Hotels Corporation, que se tornou a primeira companhia hoteleira a ser listada na Bolsa de Nova York. Em 1947 o Hilton Roosevelt de Nova Iorque tornou-se o primeiro hotel no mundo a instalar televisores nos quartos.

Em 1949 começaram as atividades do Hilton International, com a abertura do Hilton Caribe em Puerto Rico, onde foi criada a Piña Colada. Também em 1949 foi comprado o Waldorf Astoria em New York City. Também neste ano Conrad Hilton apareceu na capa da revista Time, sendo o hoteleiro a conseguir tal fato. Ele apareceria novamente na capa da revista em 1963.

Em 1954, Hilton comprou o Hotel Statler US\$ 111 milhões, maior negócio imobiliário já feito até então. No ano seguinte criou a primeira central de reservas, chamada HILCRON. As reservas podiam ser feitas para qualquer Hilton por telefone, telegrama, ou teletipo. Neste ano, a rede Hilton lançou um programa para colocar ar-condicionado em todos os hotéis.

Em 1959 Hilton lançou o conceito de hotel-aeroporto, inaugurando San Francisco Airport Hilton, com 380 apartamentos.

Em 1964, o Hilton International virou uma empresa independente, com Conrad Hilton como presidente. Dois anos depois, o filho de Conrad Hilton, Barron, assumiu a presidência da empresa americana Hilton Hotels Corporation.

Em 1965 foi lançado o Lady Hilton, o primeiro conceito de hotel projetado para mulheres viajantes. Estes hotéis tinham como características andares e apartamentos exclusivos para o público feminino, além de produtos de conveniência feitos especialmente para elas.

Em 1967 a companhia aérea TWA comprou o Hilton International. Conrad Hilton assumiu como CEO. Em 1969 foi aberto o primeiro hotel DoubleTree, em Scottsdale, Arizona.

Em 1970, o grupo Hilton tornou-se a primeira empresa listada na Bolsa de Valores de New York a entrar no segmento de jogos, com a compra de dois hotéis em Las Vegas: o Flamingo e o Las Vegas International. 
Em 1982 foi inaugurada a rede Conrad, com o objetivo de operar uma cadeia de hotéis de luxo e resorts nas maiores capitais de negócios e turismo do mundo. Em 1984 foi inaugurado o primeiro Embassy Suites, Kansas City. Neste ano também foi aberto o primeiro Hampton Inn, em Memphis, Tenessee.

Em 1987 foi lançado o Hilton Honors, o programa de fidelidade do grupo. Em 1989 foi aberto o primeiro Homewood Suites Hotel, na cidade de Omaha, Nebraska. Neste ano, a cadeia Hampton foi a primeira empresa hoteleira a prometer 100\% Satisfação Garantida, prometendo que se o cliente não ficasse satisfeito, não precisaria pagar.

Em 1990 foi aberto o Hilton Garden Inn. Em 1995 a cadeia Hilton lançou seu website: www.Hilton.com

Em 2006 o Hilton Hotels Corporation readquiriu a Hilton International, reunindo as empresas novamente. Em 2007 o Hilton Hotels Corporation completou a fusão com a empresa The Blackstone Group. Em 2009 o grupo Hilton se expandiu para 76 países, tornando-se a maior marca de hotéis full-service do mundo. Neste mesmo ano foi feita a mudança da marca, e o grupo passou a se chamar Hilton Worldwide e mudou a sede de Beverly Hills, Califórnia, para a cidade de McLean, Virginia.

Finalmente, em 2011 foi aberto o Home2 Suites na cidade de Fayetteville, North Carolina, inaugurando um novo conceito no mercado de estadia prolongada. Também neste ano o Hampton Hotels foi classificado como a melhor oportunidade de franquia pela revista Entrepreneur Magazine’s Franchise.

Em novembro de 2011, o Hilton Worldwide tinha cerca de 3.750 hotéis em 85 países de todo o mundo, somando mais de 615.000 quartos. O grupo gerencia nove marcas de hotéis, conforme pode ser visto na tabela 13: 


\section{Tabela 13 - Portfolio de Marcas do Hilton Worldwide}

\begin{tabular}{|c|c|}
\hline Marca & Hotéis \\
\hline Waldorf Astoria & 23 \\
\hline Conrad & 15 \\
\hline Hilton & 540 \\
\hline Double Tree & 200 \\
\hline Embassy & 200 \\
\hline Hilton Garden Inn & 500 \\
\hline Hampton & 1.700 \\
\hline Homewwod Suites & 300 \\
\hline Home 2 & 60 \\
\hline Outros & 212 \\
\hline Total & 3.750 \\
\hline
\end{tabular}

Fonte: Adaptado de HILTON (2011)

O grupo tem cerca de 140 mil funcionários diretos, e a receita em 2010 foi de US\$ 7,5 bilhões. Como visto na tabela anterior, a marca Hilton é uma das que compõem o portfolio do grupo. Essa marca tem 540 hotéis em 78 países do mundo, somando 193 mil quartos.

No Brasil, o grupo Hilton tem apenas dois hotéis: o de São Paulo e o de Belém do Pará. Existem alguns projetos para abertura de novos hotéis aqui, mas ainda não há nada oficial, com exceção do Hilton Salvador, que já está em construção, mas sem data para inauguração.

\subsubsection{Hotel Pesquisado}

A unidade de análise foi o hotel Hilton São Paulo Morumbi, localizado na Av. das Nações Unidas, 12901, São Paulo, SP.

De acordo com o site do hotel (HILTON, 2011), o hotel oferece a seguinte estrutura: 


\section{Acomodações}

O hotel tem 487 Apartamentos e Suítes com as seguintes comodidades:

- Controle de temperatura

- Rádio com alarme

- Roupão

- Chinelos

- Cortinas black-out

- $\quad$ TV de LCD

- Banheira separada de chuveiro

- TV a cabo

- Canal de cinema

- Mesa de trabalho

- Cadeira de trabalho ergonômica

- Cofre

- Internet banda larga

- Secador de cabelo

- Cafeteira

- Ferro de passar roupa

- Refrigerador

- Aparelhos de telefone com duas linhas, viva voz e correio de voz

- Banheiro de mármore

- Travesseiros de pena de ganso

- Roupa de cama 100\% algodão

- Produtos de banho

- Serviços de turndown

\section{Serviços ao Hóspede}

Os principais serviços oferecidos pelo hotel aos seus hóspedes são:

- Concierge 24 horas

- Serviço de quarto 24 horas

- Business Center 
- 2 restaurantes (Buffet e Cozinha contemporânea)

- Cafeteria

- Spa

- Fitness Center com $1.500 \mathrm{~m}^{2}$

- Equipamentos de áudio/vídeo

- Aluguel de telefone celular

- Serviço de cópias e fotos

- Impressoras

- Serviço de Secretaria

- Vídeo conferência

- Cardápio infantil

- Aluguel de vídeos infantis

- Escritório de Companhia Aérea American Airlines

- Salão de beleza Jacques Janine

- Escritório de aluguel de carro

- Lavanderia

- Serviço de Valet

- Piscina

- Comida vegetariana e kosher

- Espaços com vista panorâmica

- Lounge exclusivo

- Lojas

- Centro de Convenções

- Estacionamento

\subsubsection{Questões gerais de Marketing}

A tarifa média do hotel é de $\mathrm{R} \$ 600,00$, e a taxa de ocupação é de $85 \%$. Para alcançarem esta marca, o hotel consegue praticamente $100 \%$ de ocupação entre $2^{\mathrm{a}}$ e $5^{\mathrm{a}}$ feira, caindo para cerca de $60 \%$ durante os fins de semana. Como pode ser observado, é uma situação muito parecida com o do hotel Hyatt. A estadia média no Hilton é de quatro noites. 
A visão que CASTRO (2011) tem da diferenciação do hotel é interessante. Segundo ele:

“nosso diferencial está nos serviços que oferecemos, pois o intangível é mais lucrativo que o tangível. Por isso, focamos em oferecer pequenas coisas muito baratas, que é o que eu chamo de “customização padronizada". A customização não é com a oferta, mas com o processo. Por exemplo, eu percebi que você pediu café e água. Da próxima vez que vier aqui, eu mandarei servir café e água, porque já sei que é o que você toma."

Nesta linha de raciocínio, ele afirma passar para sua equipe a ideia de "quanto vale um sorriso?”. Esta ideia é colocada para os funcionários mostrando que não custa muito sorrir, e que os benefícios que isto traz em termos de satisfação dos clientes é considerável. Isto parece claro nas palavras do próprio CASTRO (2011):

"Nós estratificamos tanto a linha de produção que os funcionários não tem contato com o produto final, ou seja, ele não sabe quanto que o seu trabalho ou sua função gera para a empresa. O que a gente procura fazer internamente é criar esta conexão. A história do sorriso vem daí, de um cálculo em que eu procuro mostrar que o sorriso é importante na avaliação dos clientes, porque nos comentários positivos e negativos, o sorriso e a amabilidade sempre aparecem. Com isso, eu consigo criar uma cultura de receitas. Revenue management, que está tão em moda, não é só no apartamento. É também no sorriso, no catering, na academia e também em TI."

Este ponto parece bastante interessante, pois coloca a questão do atendimento e da prestação de serviços como algo que pode e deve ser feito como elementos que agregam valor, a partir de atitudes simples. Indo além, a visão de Castro a respeito da área de TI também passa por uma visão crítica a respeito do que é feito por essas áreas na hotelaria. Segundo ele:

"Se TI é tecnologia da informação, por que está na área financeira? Por que a gente não provê nenhum tipo de informação para o hóspede, a não ser consertar o Office e instalar o Windows? Se eu sou de TI, por que não passo nenhuma informação para ninguém?" 
Por causa deste questionamento, foi desenvolvido um projeto junto com outras áreas, e que envolve a área de TI. No $1^{\circ}$ andar tem um videowall feito a partir de uma parceria com a LG, com 9 telas de 46 polegadas. Outras 60 telas que estão sendo instaladas no interior do hotel para criar o digital signage interno. O objetivo é fornecer informações úteis para os hóspedes sobre o hotel, os serviços disponíveis, etc...

O perfil do cliente do Hilton é formado basicamente pelo público corporativo, incluindo executivos, grupos de convenções e eventos (30\%), empresas com acordos corporativos e tripulações. Do universo de hóspedes, $50 \%$ são norte-americanos. Segundo Castro, isso é importante para as ações do hotel, porque é "um público que não gosta de contato pessoal quer rapidez e eficiência."

As ações de marketing são divididas: algumas devem seguir padrões globais, enquanto outras podem ser desenvolvidas localmente, apenas respeitando os polices da empresa. Dentre as ações citadas, o foco maior são as corporações e, evidentemente, as ações são dirigidas aos decisores e influenciadores de compra. Estas ações incluem estadias gratuitas e ações institucionais e de relações públicas.

Existe uma grande preocupação com as ações locais porque o relacionamento é criado localmente a partir de ações simples e baratas. Para isso, é desenvolvido um trabalho de CRM que visa entender um pouco mais quem são os tomadores de decisão, o que gostam, por que gostam de determinadas coisas, qual seu momento profissional na empresa onde atua, etc...

Como exemplo, o executivo citou a o trabalho feito para se conseguir um acordo com a Oracle. Para isso, descobriram que o presidente da empresa era torcedor do Vasco da Gama e enviaram uma camiseta do time quando este ganhou uma partida. Além disso, descobriram que a secretária do presidente gostava muito de sua cachorra, e mandaram fazer uma roupa para o animal com a inscrição "Hilton Pet".

Segundo CASTRO (2011):

“Chegou o momento da negociação, em junho. Nós não fomos aprovados como o hotel preferencial para o ano, por que não podíamos baixar a tarifa oferecida. Ou seja, mantivemos a relação, mas não teríamos o acordo 
comercial, e eles foram testar a concorrência. As ações que fizemos surtiram efeito, porque participamos do novo processo e hoje somos o hotel preferencial da Oracle, com a tarifa que tínhamos oferecido. Isso significa que esse relacionamento, no final, se reverte em dinheiro."

As preferências dos hóspedes alimentam um banco de dados, e a satisfação dos clientes é feita através de uma pesquisa, que por sua vez alimenta um software chamado SALT, que foi desenvolvido pelo próprio Hilton. Com este relatório a empresa consegue checar cada item avaliado e analisar os itens segundo seu grau de importância.

A comunicação é restrita a algumas poucas ações diretamente com o trade e público corporativo. Com os hóspedes, existem canais internos, como TV nos elevadores, além do digital signage já explicado.

O hotel também tem uma suíte na casa de espetáculos Via Funchal, com 12 lugares, chamada Celebrity Lounge, que é usada para ações de relacionamento e também para pacotes com programação cultural que são desenvolvidas pelo hotel.

\subsubsection{Visão sobre Marketing Experiencial}

Questionado sobre ações de Marketing Experiencial, o executivo não soube responder. Disse que ouve falar muito disso, mas que não tem uma visão clara do que seja. Entende apenas que a experiência que o hóspede leva do hotel, ou seja, a percepção de como foi o período em que esteve hospedado é fundamental para um possível retorno.

Esta percepção é formada fundamentalmente pelos serviços ofertados, e também pelo que ele chamou de "pequenas coisas muito baratas".

CASTRO (2011) afirma que

"em hotelaria, se os hóspedes não tem uma experiência boa, eles não voltam nunca mais. Então, precisamos ter uma constante no nosso nivel de serviços que vá levar a uma experiência, a uma sensação de bem estar. E essa 
sensação de bem estar é variável - para uns pode ser a cama, para outros pode ser o sorriso. Se conseguirmos entender isso, então podemos dizer, com consistência, que nosso atendimento é para um público $X$, que gosta de coisas A, B e C. É a customização padronizada. Se quisermos agradar todo mundo, não vamos agradar ninguém. Se quisermos oferecer uma boa experiência para esse público, temos que traçar um perfil e seguir este perfil. Entendendo isso, podemos deixar de atender 20\%, mas os outros $80 \%$ vão voltar. E isso gera o relacionamento, e não somente uma transação."

Apesar de não ter opinião formada sobre Marketing Experiencial, o discurso de Castro reflete uma postura racional e equilibrada em termos de ações de marketing, na medida em que aborda o conceito básico de segmentação de mercado e os diferentes tipos de consumidores, e destaca a satisfação como meio para que se alcance a preferência e fidelidade por parte dos hóspedes.

$\mathrm{Na}$ análise feita no hotel Hyatt, foi observado que a promessa de uma "experiência única" era destacada no site da empresa, ainda que o conceito de experiência e marketing experiencial não fossem claros.

Isto também acontece no hotel Hilton, ou seja, ainda que o executivo do Hilton não tenha uma opinião clara do que seja experiência ou marketing experiencial, o fato é que a promessa de "experiência" também é destacada em diversas páginas do site do hotel que, também para o Hilton, é uma das principais ferramentas de comunicação de marketing.

É interessante, como pode ser visto nas ilustrações a seguir, que a promessa de experiência varia de "experiência que só o Hilton pode oferecer", no caso do "Pacote Bed \& Breakfast" (ilustração 30), "experiência relaxante", no caso do "Pacote Relaxante" (ilustração 31), e também “experiência memorável”, no caso do "Pacote Romântico" (ilustração 32).

De certa forma, isto comprova uma das afirmações feitas na primeira parte deste trabalho, que a palavra "experiência" tornou-se moda e passou a ser usada intensamente em peças de comunicação publicitária. 


\section{Ilustração 30: Site - Pacote Bed \& Breakfast}

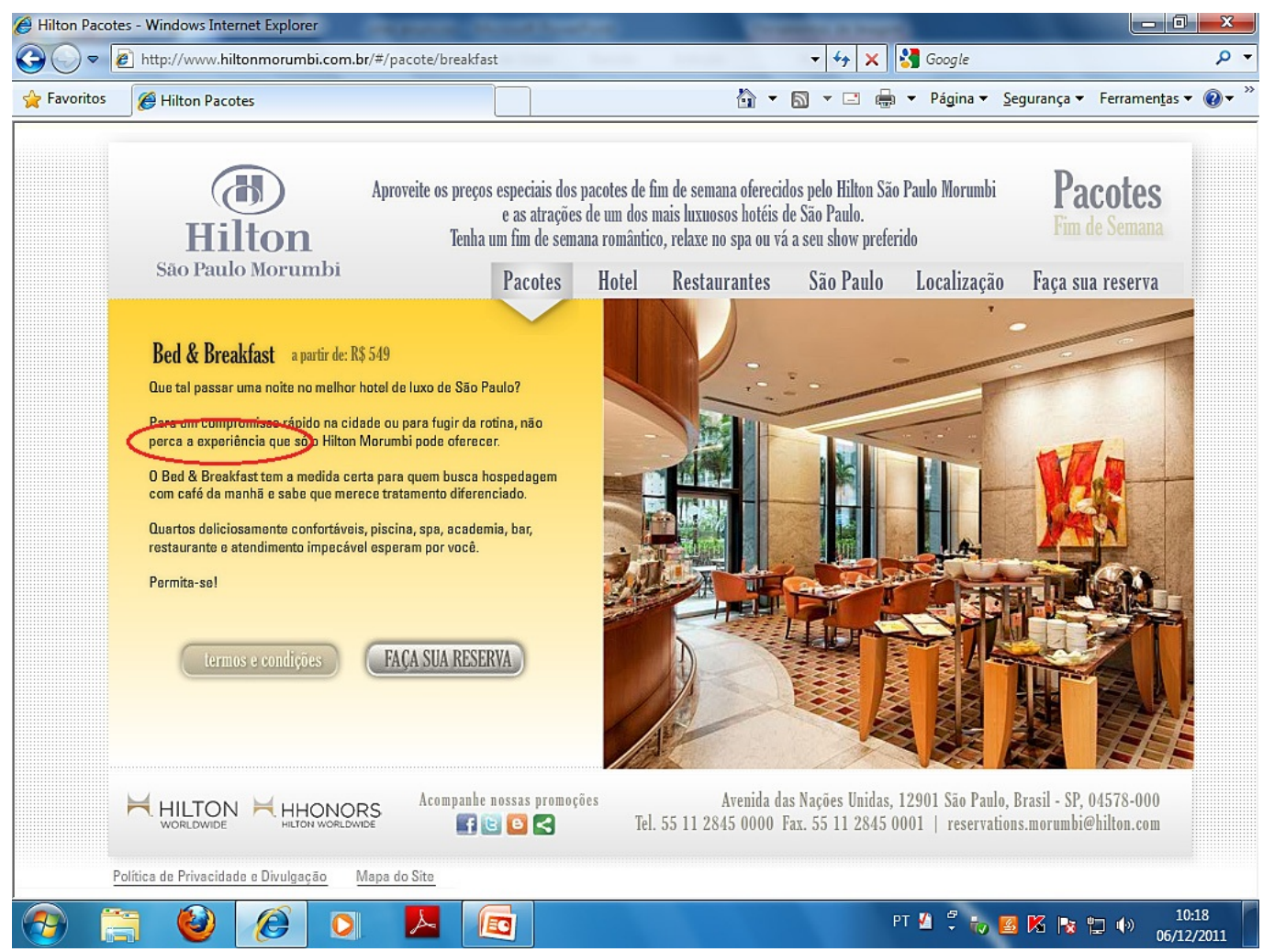

Fonte: HILTON, 2011

\section{Ilustração 31: Site - Pacote Relaxante}

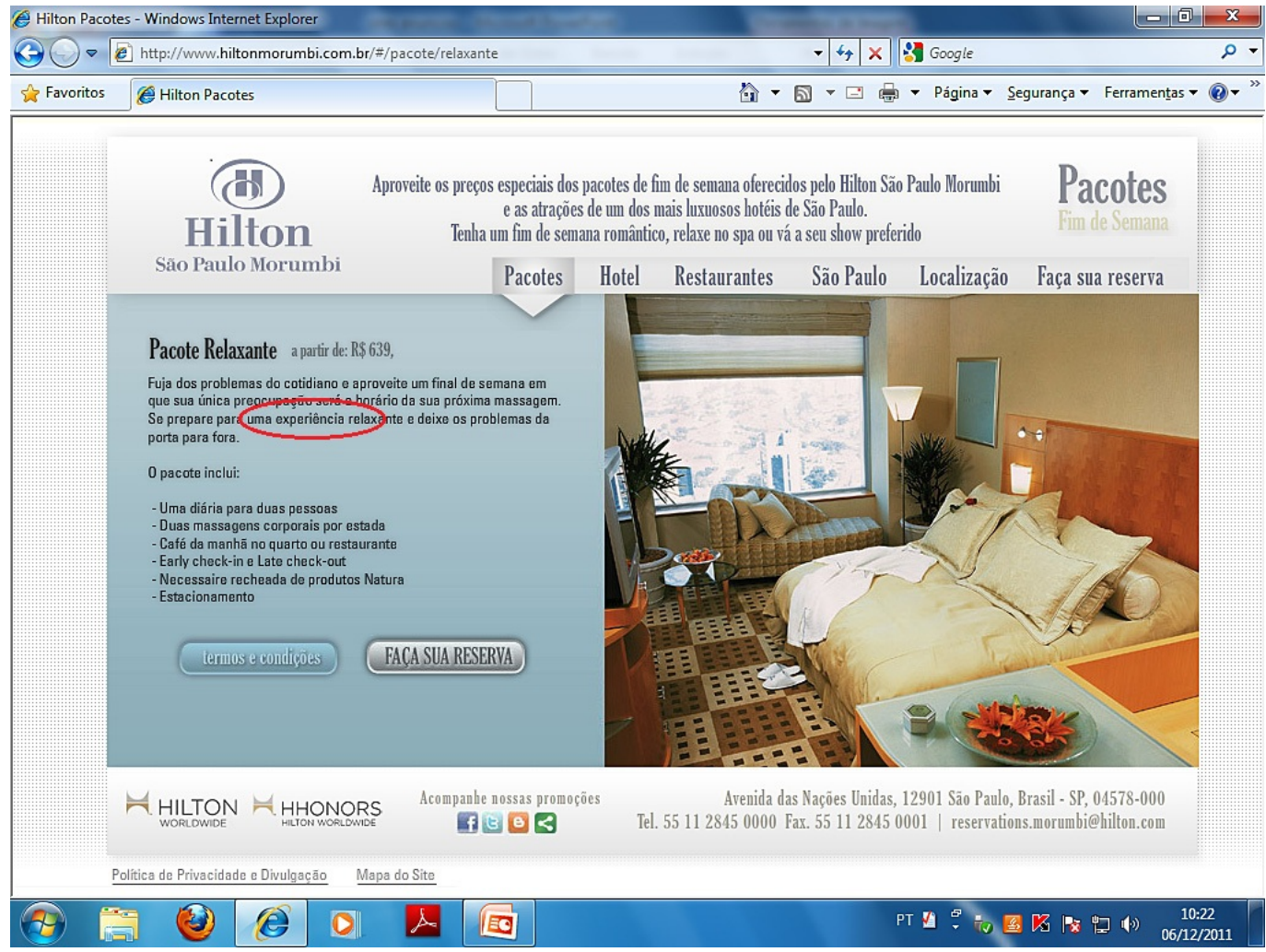

Fonte: HILTON, 2011 


\section{Ilustração 32: Site - Pacote Romântico}

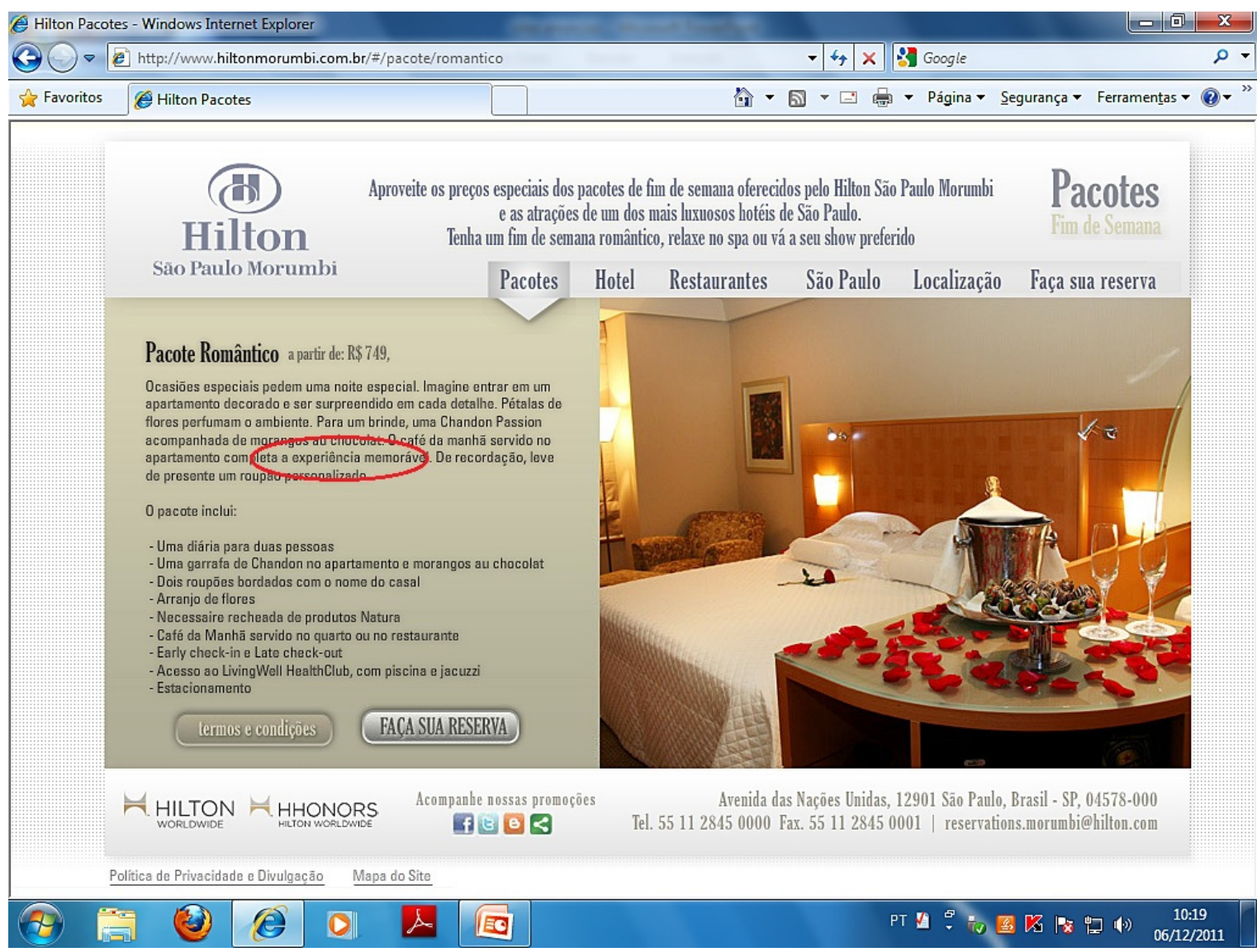

Fonte: HILTON, 2011

Como visto, em que pese o termo "experiência" ser usado com diferentes conotações, sempre procuram, neste caso do Hilton, remeter à ideia de um serviço diferenciado e de alta qualidade.

\subsubsection{Ações Sensoriais}

\section{Visão}

A arquitetura do Hilton tem uma proposta bastante moderna, ágil, focada no público norteamericano, que representa $50 \%$ dos seus hóspedes. Esta proposta é percebida não apenas no design arrojado, com uso intensivo de tecnologia, como também nos materiais usados, com muito vidro, concreto e aço. 
Este conceito é perceptível a partir da arquitetura do prédio, não apenas imponente, mas com um projeto arquitetônico diferenciado, como vemos na ilustração 33.

\section{Ilustração 33: Fachada do hotel Hilton}

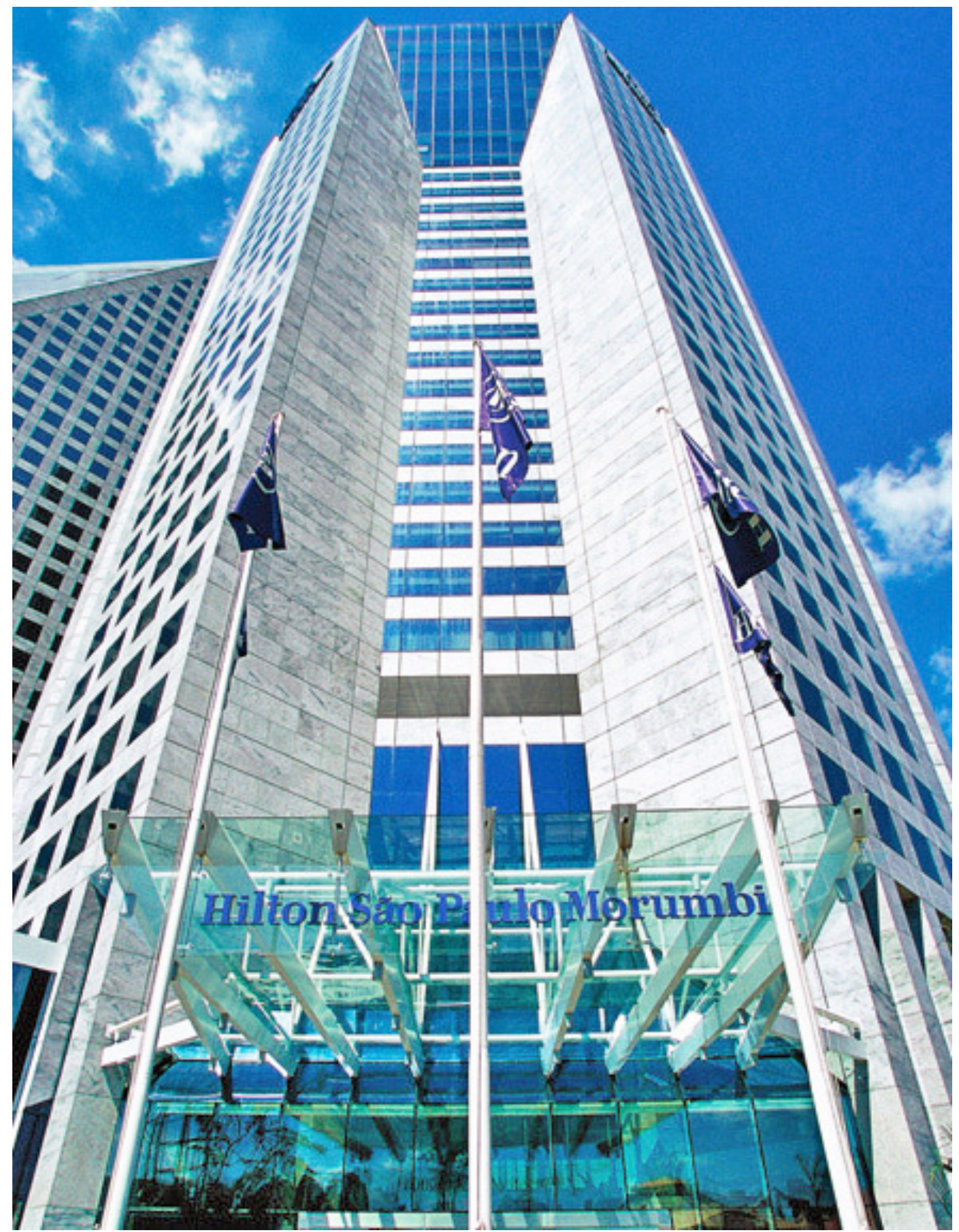

Fonte: HILTON, 2011 
O mesmo conceito é reforçado no lobby do hotel, onde existe uma grande escultura tipo móbile, feita em vidro, e que representa uma caravela. A partir desta escultura é que foram pensadas as outras peças que decoram o lobby, ou seja, os tapetes, os dois foyers e os quadros, que também devem passar a imagem de modernidade. Esta escultura pode ser vista nas ilustrações 34 e 35 .

Ilustração 34: Escultura do lobby vista de cima

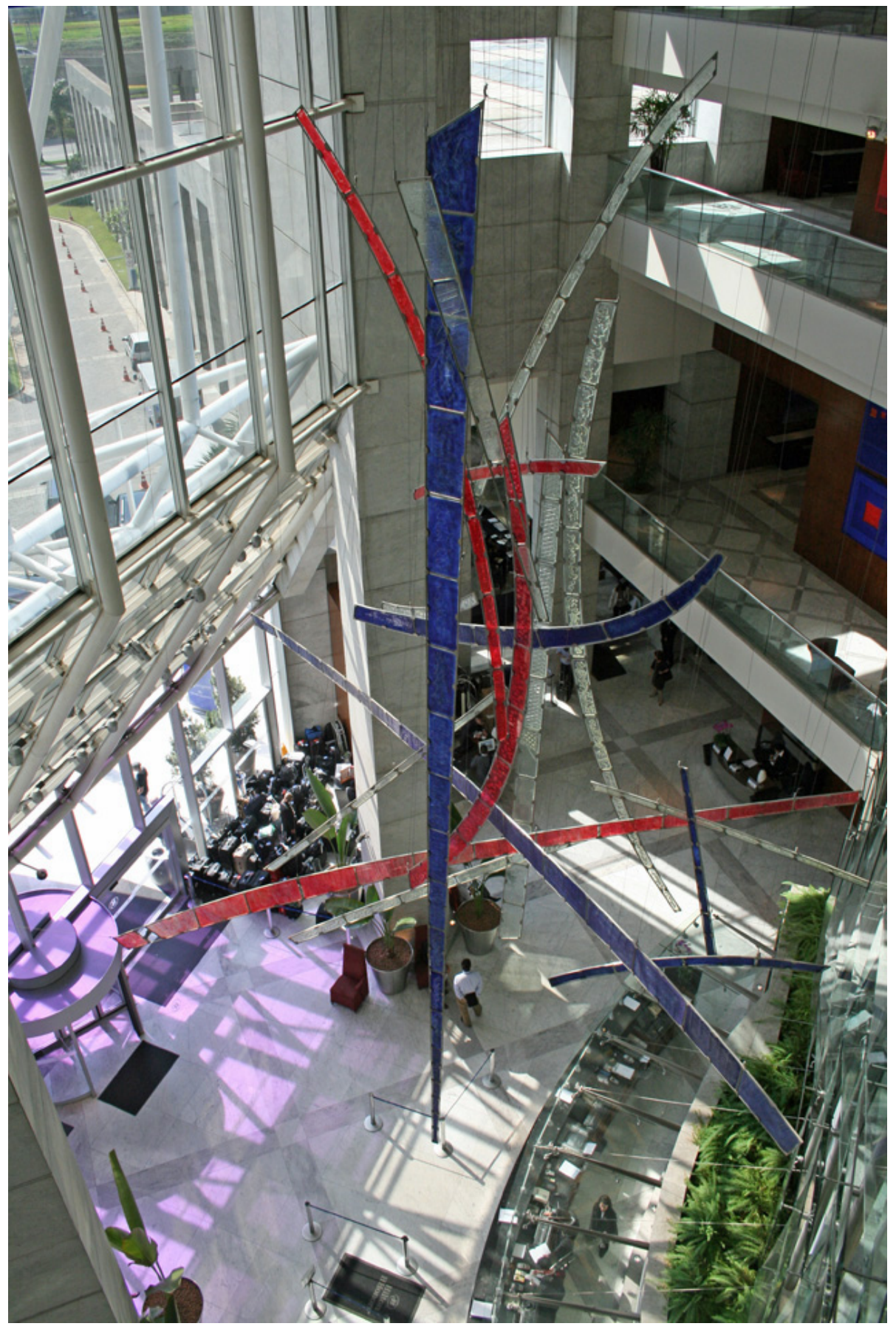

Fonte: foto tirada pelo autor, em visita realizada dia 19/11/2011 


\section{Ilustração 35: Escultura do lobby - vista lateral}

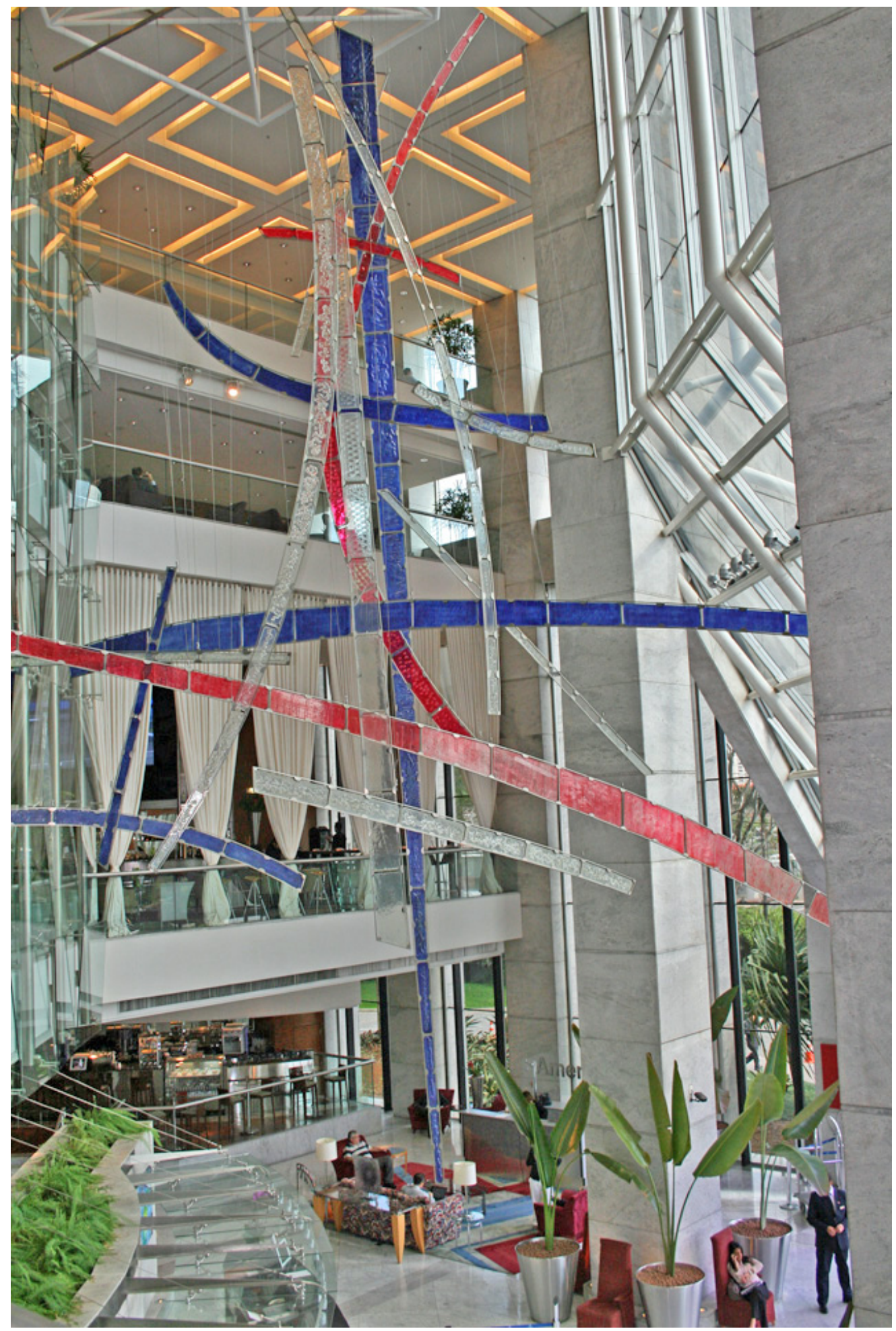

Fonte: foto tirada pelo autor, em visita realizada dia 19/11/2011

Como visto nas ilustrações anteriores, o conceito de grandeza também é trabalhado no hotel Hilton. Isso fica claro não apenas pelo porte do seu edifício, com seus 487 apartamentos, como também pelo lobby monumental com envoltório em vidro. 
No entanto, esse conceito de grandeza não fica restrito a estas áreas. Ao contrário, existem outros aspectos da concepção visual do hotel que colaboram para que esse conceito seja percebido. Sob o ponto de vista arquitetônico, isso é bem visível no tamanho das janelas, que na maioria dos locais tem uma dimensão maior que o normal, proporcionando não apenas uma bela vista panorâmica, como também criando a percepção de espaços maiores, principalmente durante o dia, em função da iluminação natural.

Alguns exemplos disto podem ser vistos nas ilustrações seguintes que mostram, respectivamente, a piscina do hotel (36), uma das suítes (37), o restaurante Sol e Sombra (38), e o Lounge Executivo (39).

\section{Ilustração 36: Piscina}

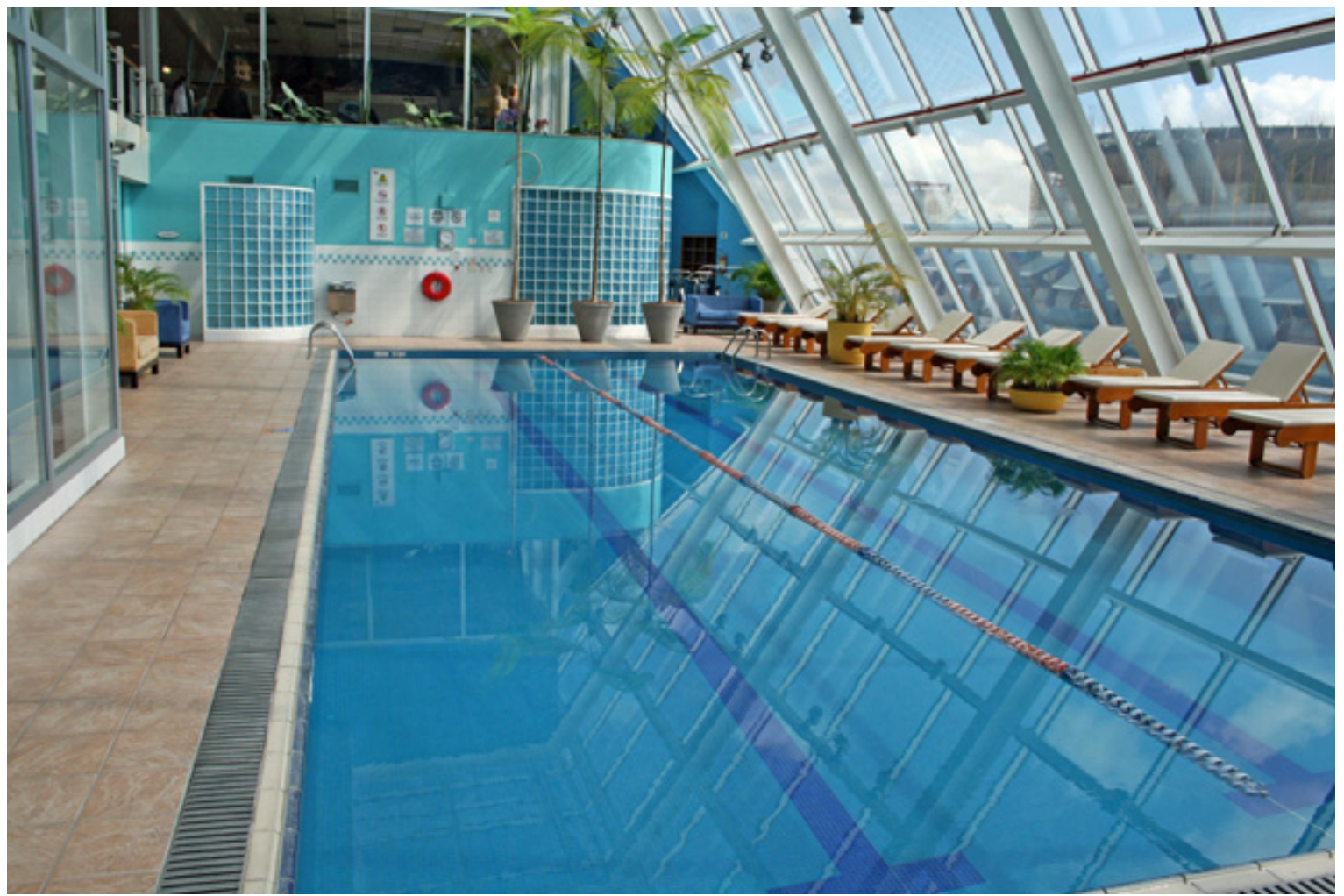

Fonte: foto tirada pelo autor, em visita realizada dia 19/11/2011 


\section{Ilustração 37: Suítes}

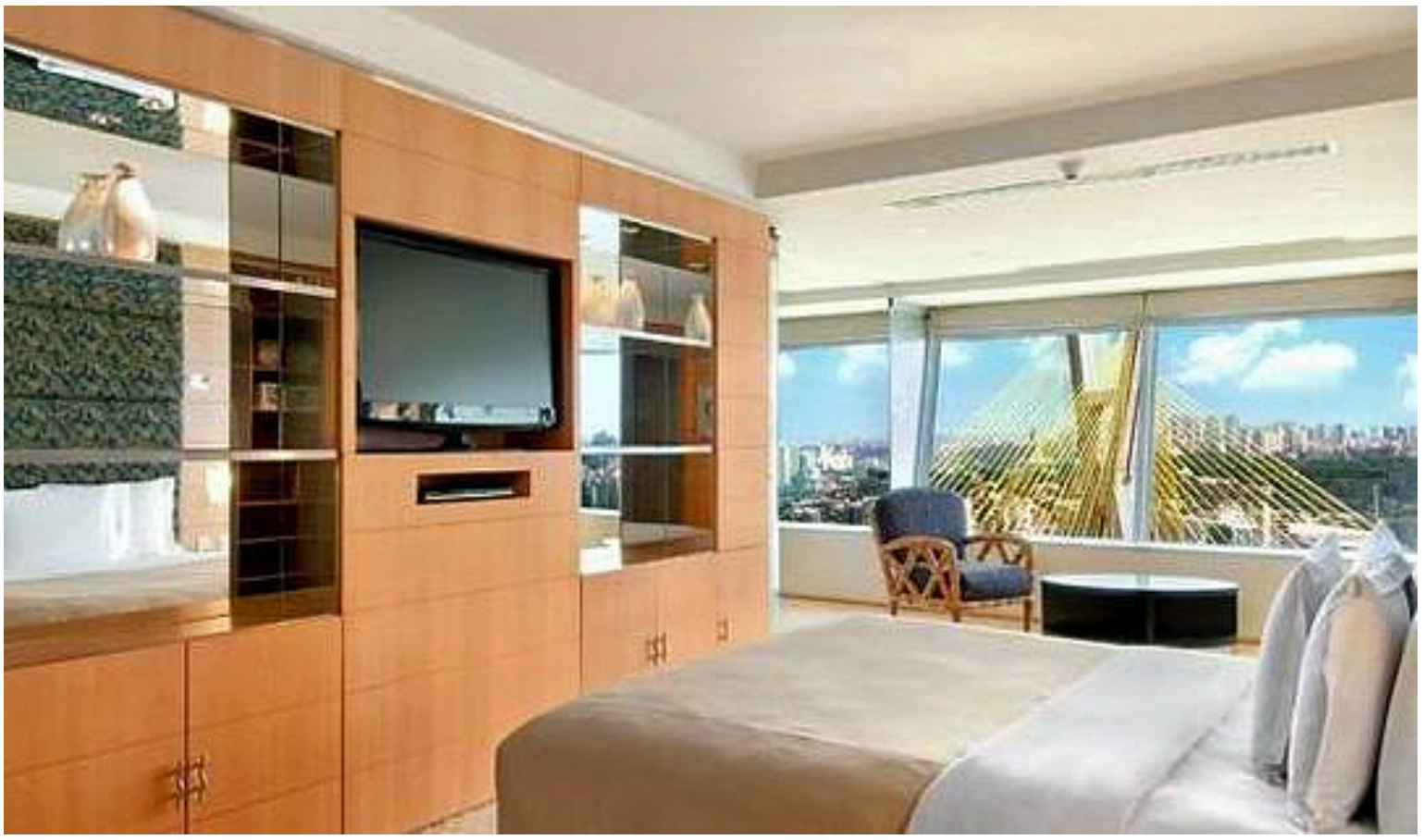

Fonte: HILTON, 2011

Ilustração 38: Restaurante Sol e Sombra

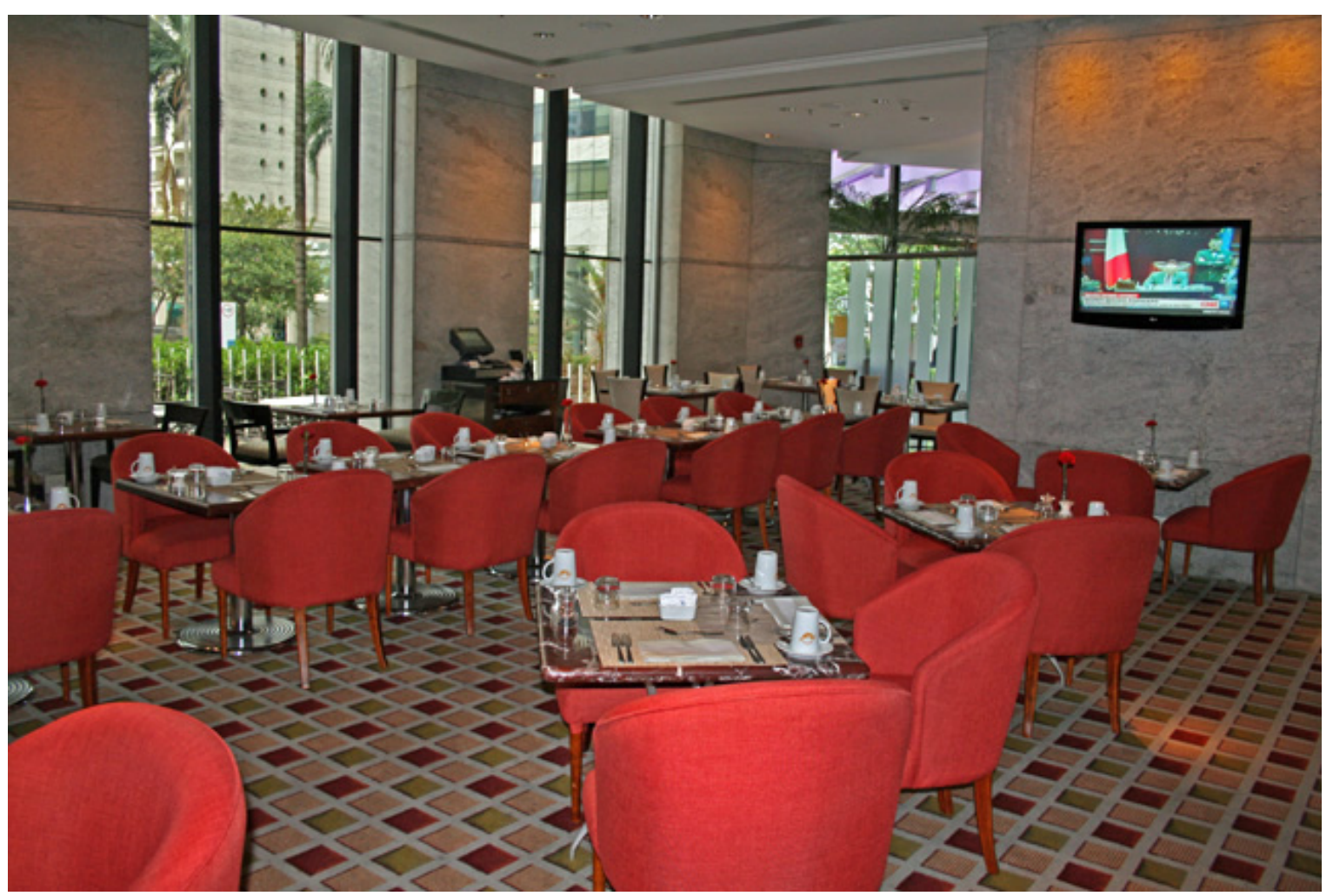

Fonte: foto tirada pelo autor, em visita realizada dia 19/11/2011 


\section{Ilustração 39: Lounge Executivo}

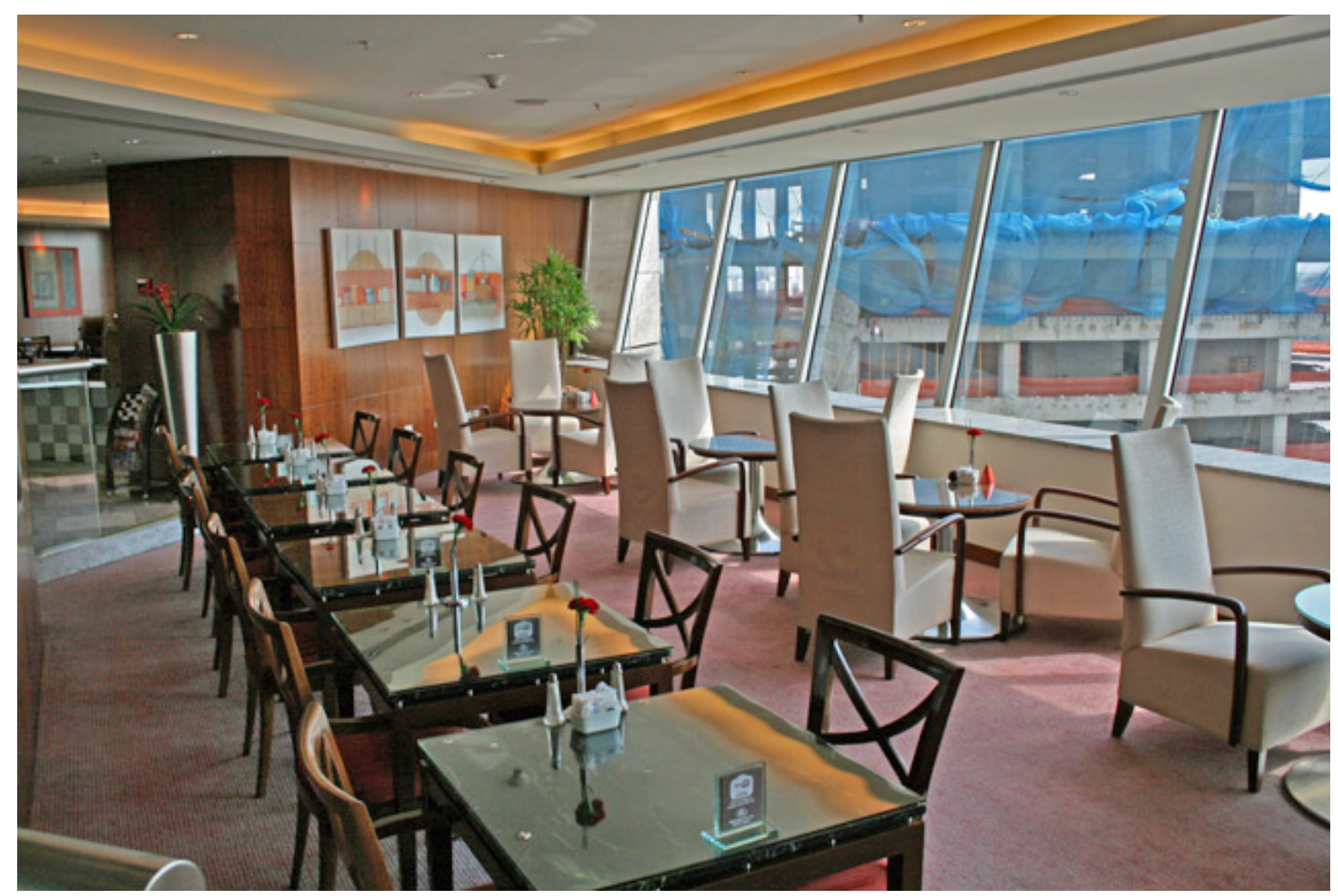

Fonte: foto tirada pelo autor, em visita realizada dia 19/11/2011

Como visto, o conceito de grandiosidade é bastante visível no Hilton. Além disso, a ideia de modernidade também está presente. Como observado nas ilustrações anteriores, os aspectos arquitetônicos das instalações, como já citado, usam materiais como vidro e aço e, seguindo essa linha, os móveis e objetos de decoração apresentam um design bastante contemporâneo, fugindo um pouco de um padrão visual mais clássico.

Esta mesma linha estética fica ainda mais evidente quando se observa que a escultura e a decoração existentes no lobby convergem para o restaurante Canvas, o principal do hotel, que é um "restaurante-galeria de arte".

Este restaurante cria um cenário de galeria de arte, como vemos na ilustração 40, onde se percebe ao fundo as enormes janelas reforçando a escala do projeto. 


\section{Ilustração 40: Restaurante Canvas}

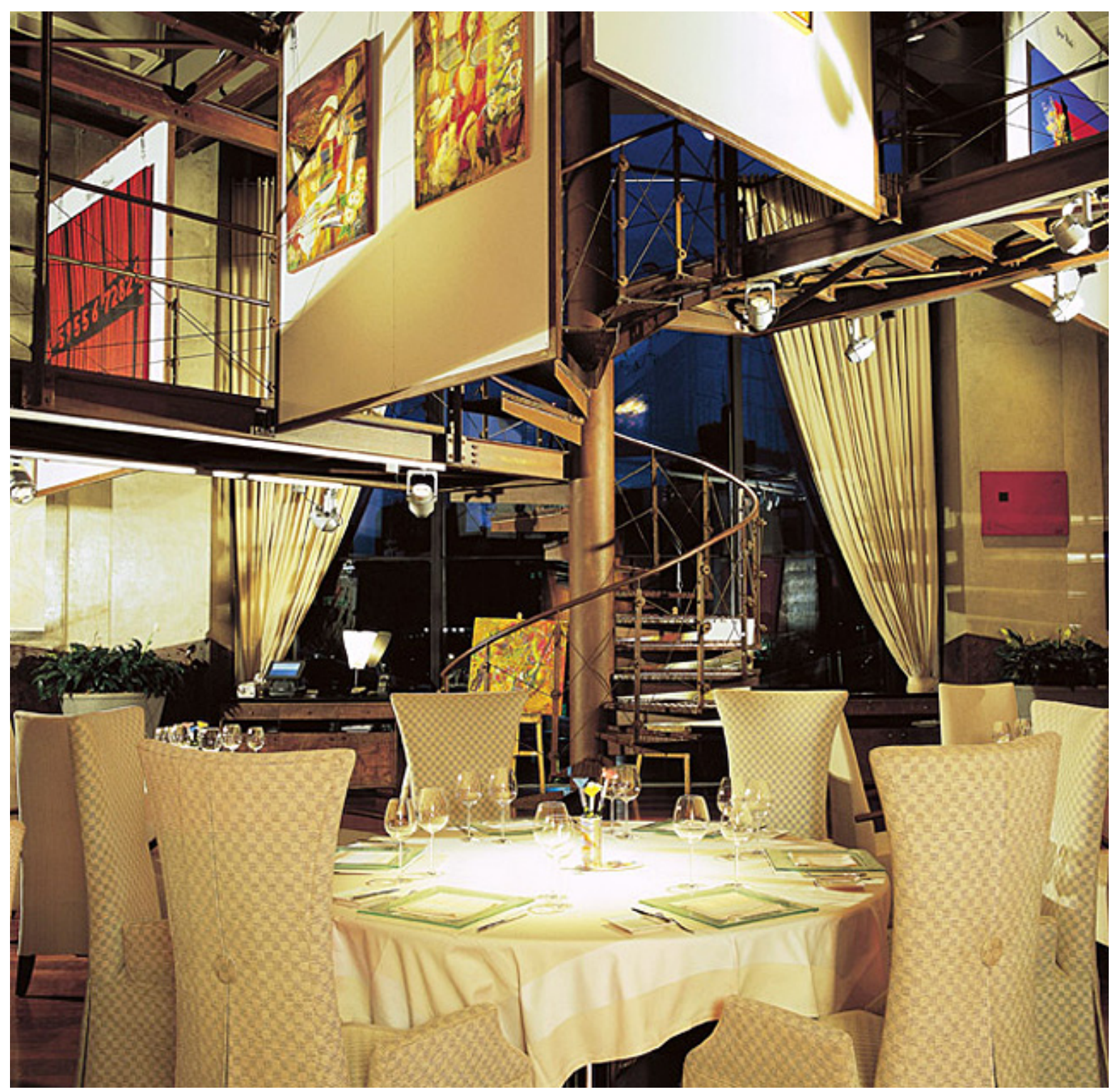

Fonte: TRIP ADVISOR, 2011

Esta preocupação estética com elementos modernos se estende em outros detalhes dentro do restaurante, como visto na figura 41, que mostra a escadaria feita em vidro e aço, ou seja, com materiais bastante diferenciados. 


\section{Ilustração 41: Escadaria do restaurante Canvas}

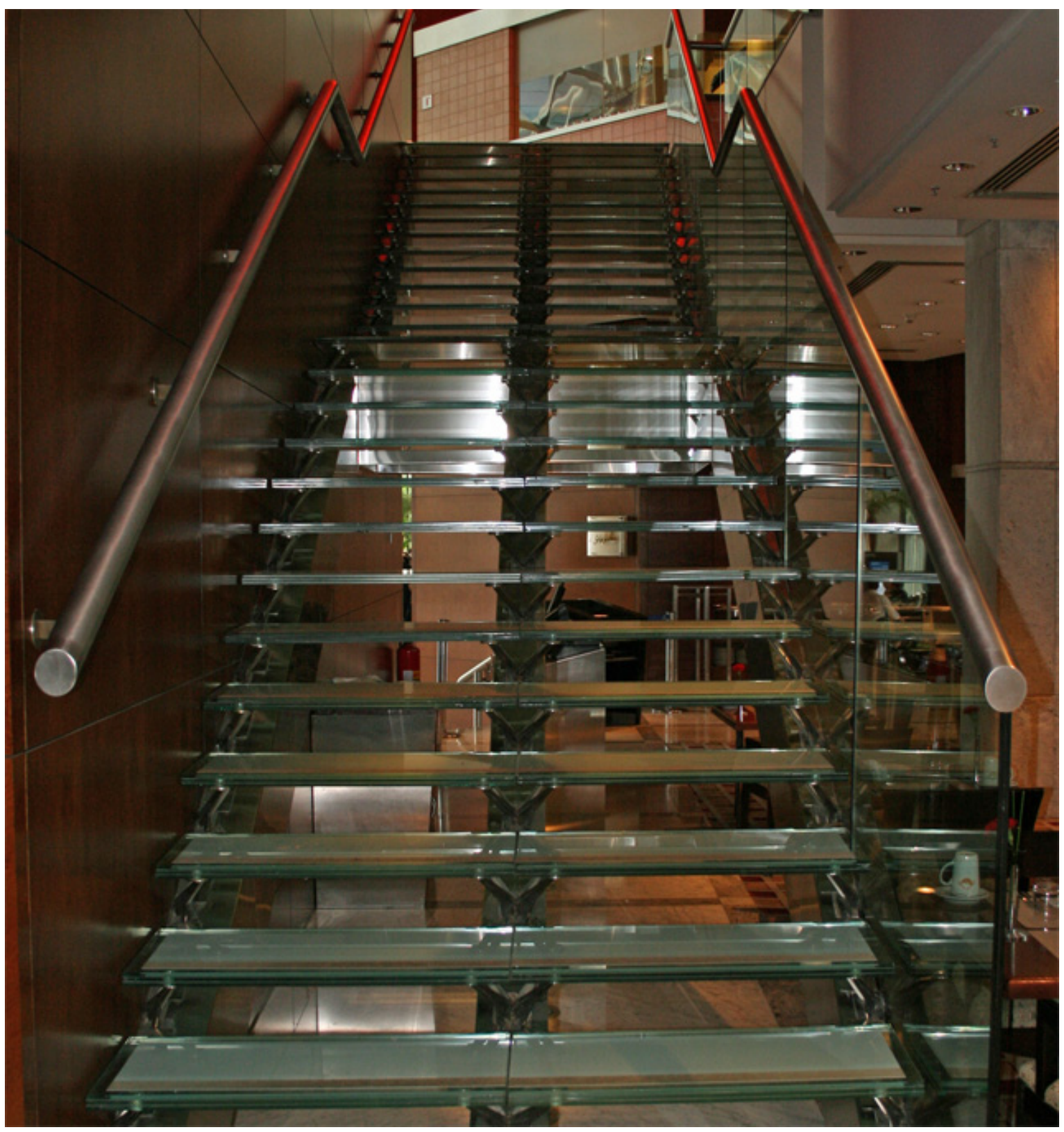

Fonte: foto tirada pelo autor, em visita realizada dia 19/11/2011

Como citado, o restaurante Canvas é um restaurante com uma galeria de arte suspensa. Os quadros que decoram as paredes, como pode ser visto na ilustração 42 , pertencem ao acervo do hotel. Evidentemente, esses quadros fazem parte de uma linha artística mais contemporânea, coerente com a proposta do hotel. 
Ilustração 42: Quadro do restaurante Canvas

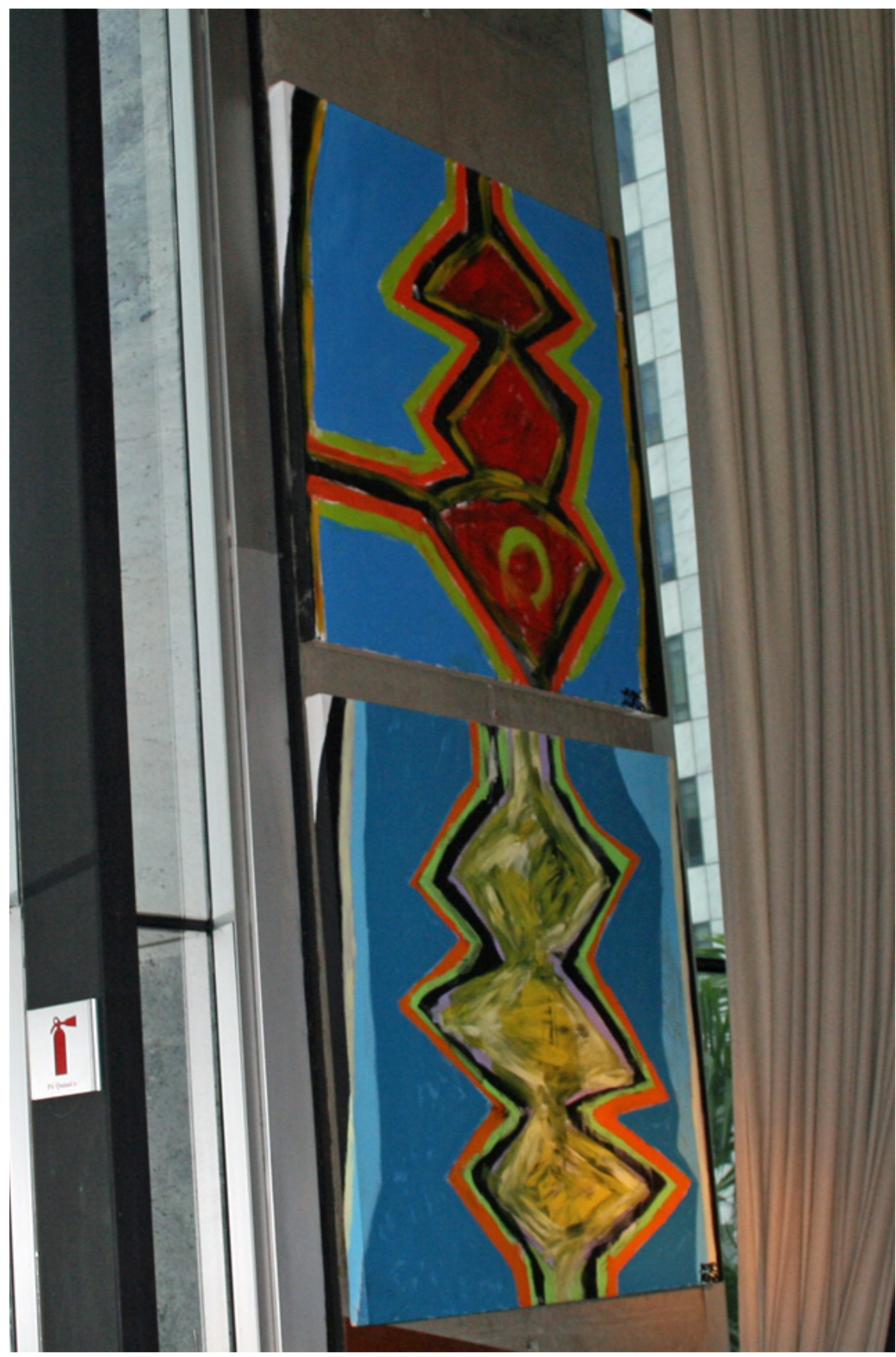

Fonte: foto tirada pelo autor, em visita realizada dia 19/11/2011

Mais ainda, para reforçar o conceito de galeria de arte, os quadros que ficam expostos nas estruturas suspensas podem ser comprados pelos hóspedes. Para isso, como ocorre em qualquer galeria de arte, a do restaurante Canvas também faz uma série de exposições durante o ano. 
No dia em que foi feita uma das visitas para a realização desta tese, o restaurante estava se preparando para uma exposição do artista brasileiro e mundialmente famoso Romero Britto. $\mathrm{O}$ site do restaurante, que pode ser acessado pelo site do hotel, já fazia a divulgação da exposição, com uma página que remete ao estilo do artista, claramente moderno, conforme comprovado na ilustração 43.

\section{Ilustração 43: Site do restaurante Canvas}

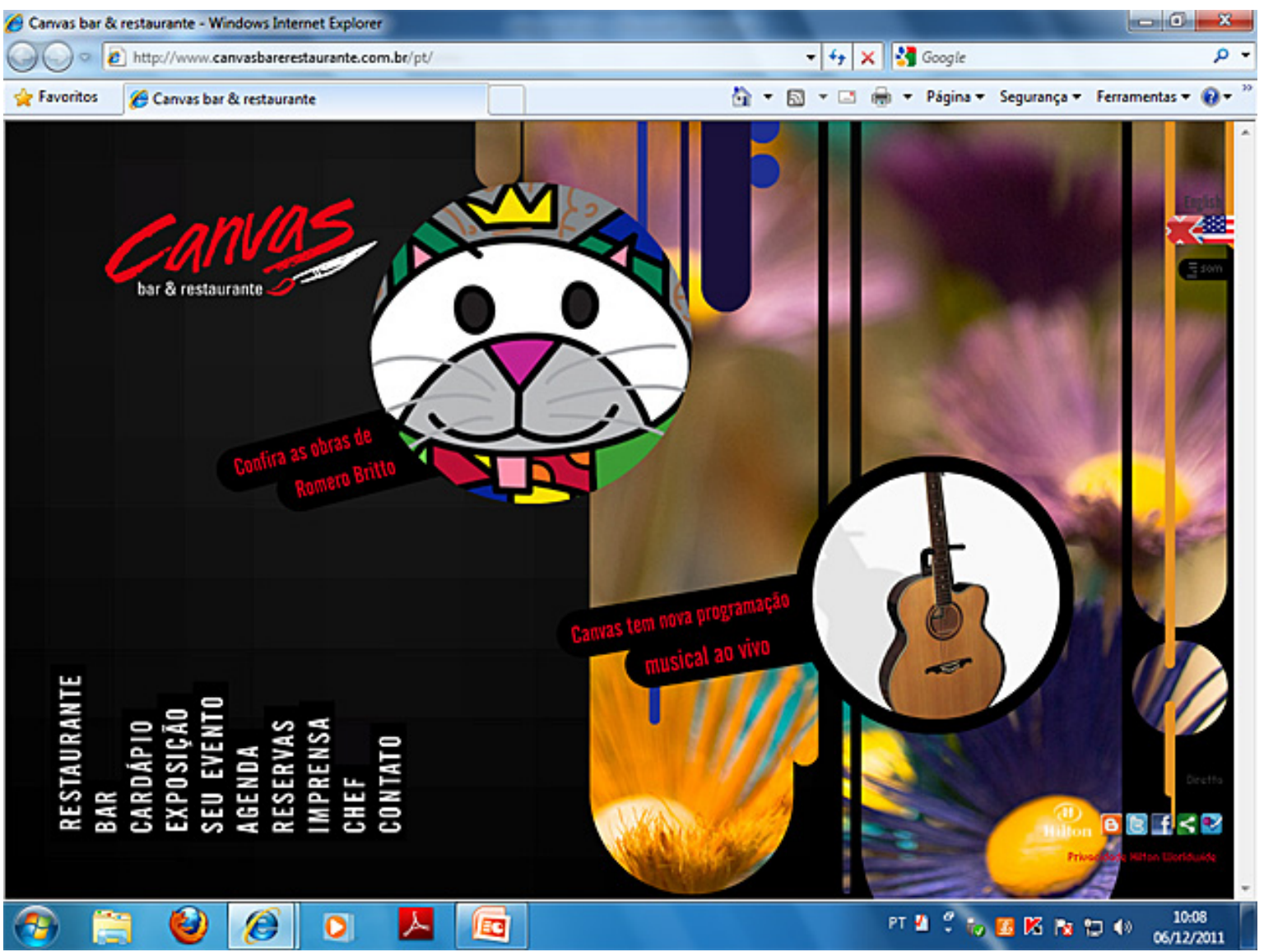

Fonte: HILTON, 2011

O Canvas não chama a atenção apenas pela sua arquitetura, decoração, ou pelas obras de arte ali expostas. Na verdade, o sentido da visão é explorado em vários detalhes, que são ligados ao conceito de galeria de arte.

Como exemplo, pode ser visto nas ilustrações 44 e 45 os cardápios do restaurante, feitos com telas de pintura. Podemos perceber que cada cardápio tem uma moldura com uma pintura diferente, respeitando apenas o mesmo estilo. 
Outro detalhe a respeito do sentido da visão pode ser confirmado pela ilustração 46, que mostra o design dos pratos do restaurante, feitos de vidro, com forma e textura que fogem do convencional, e seguem a estética de modernidade .

\section{Ilustração 44: Cardápio do restaurante Canvas}

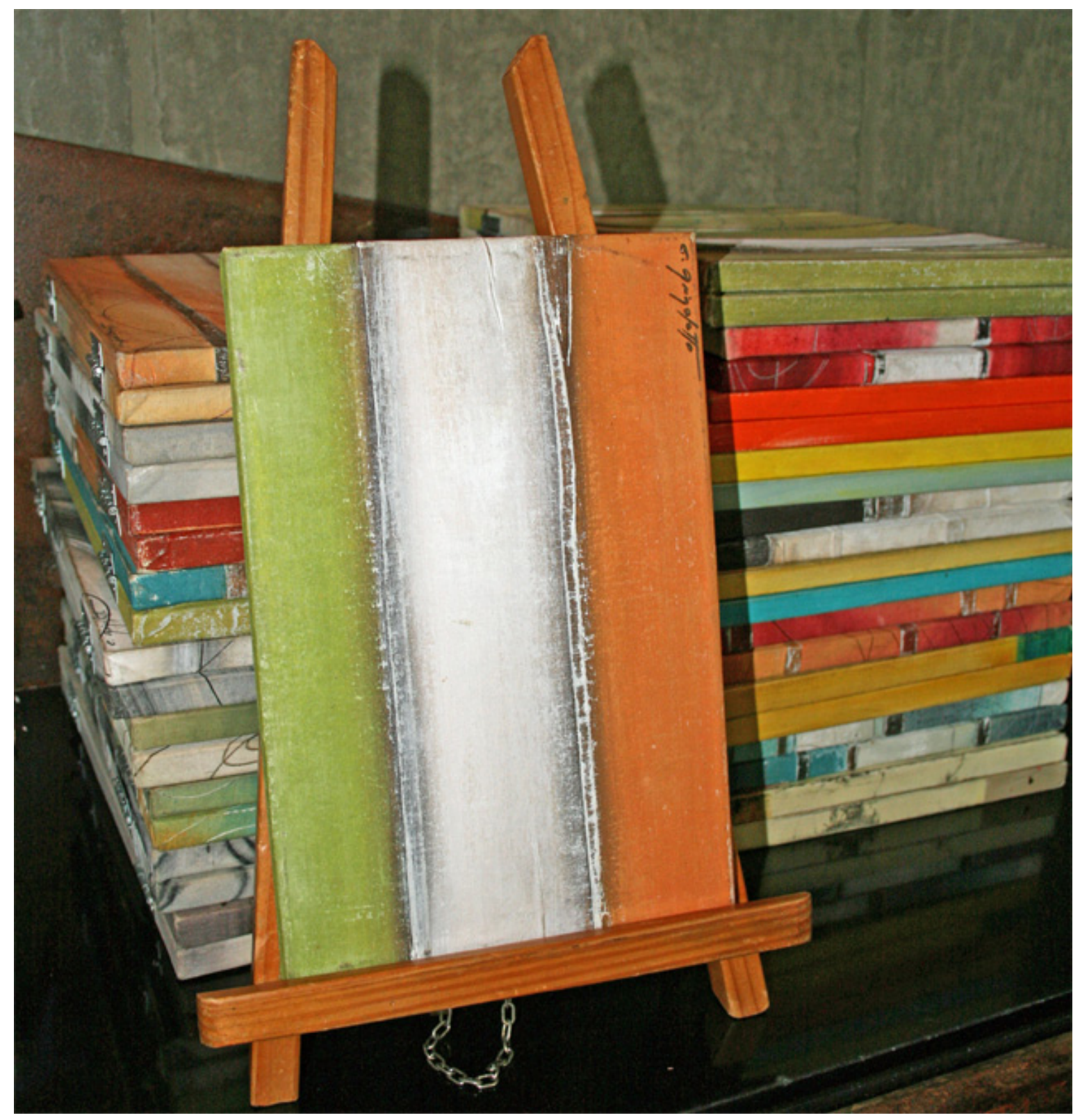

Fonte: foto tirada pelo autor, em visita realizada dia 19/11/2011 
Ilustração 45: Cardápio do restaurante Canvas

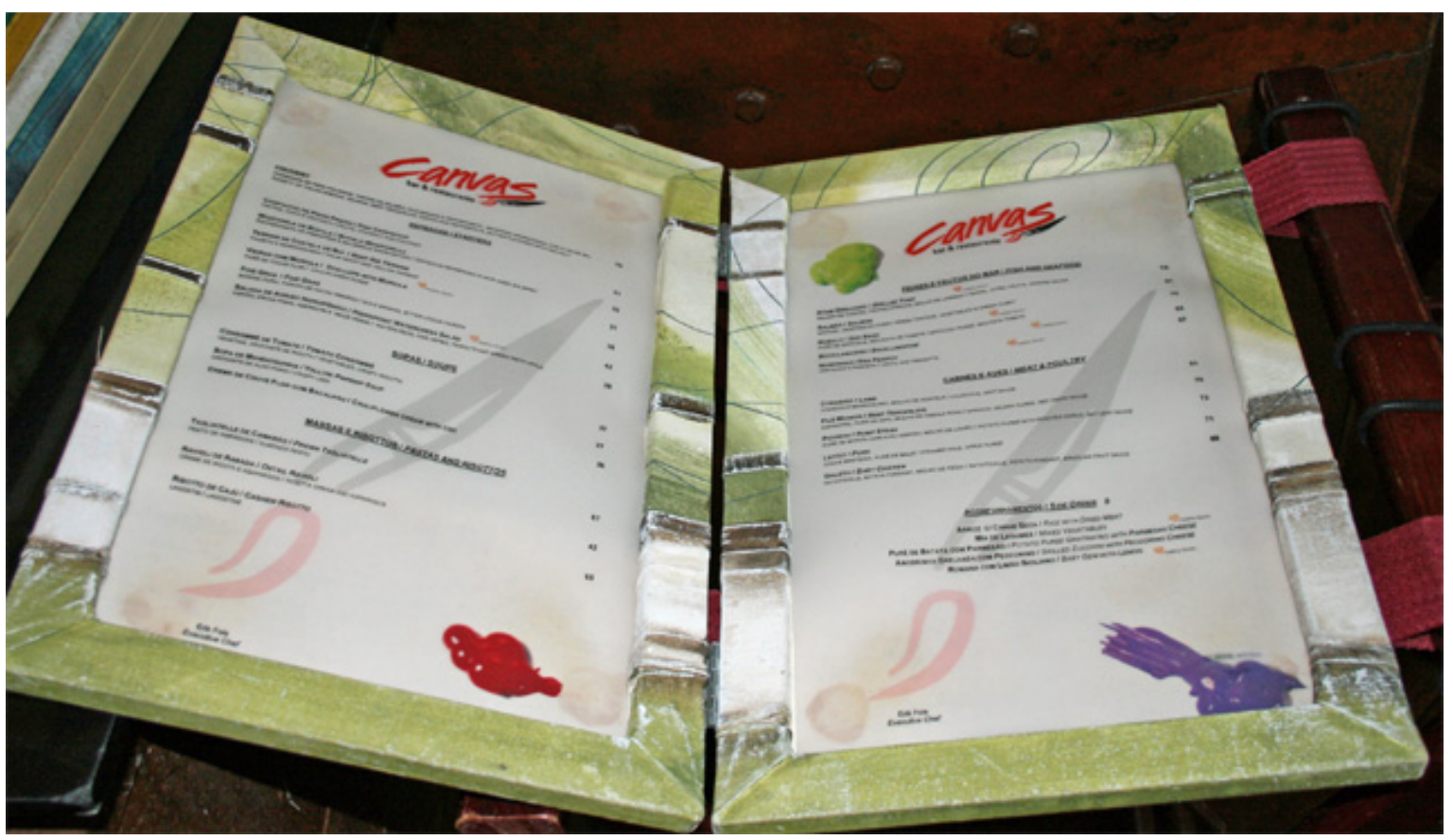

Fonte: foto tirada pelo autor, em visita realizada dia 19/11/2011

\section{Ilustração 46: Prato do restaurante Canvas}

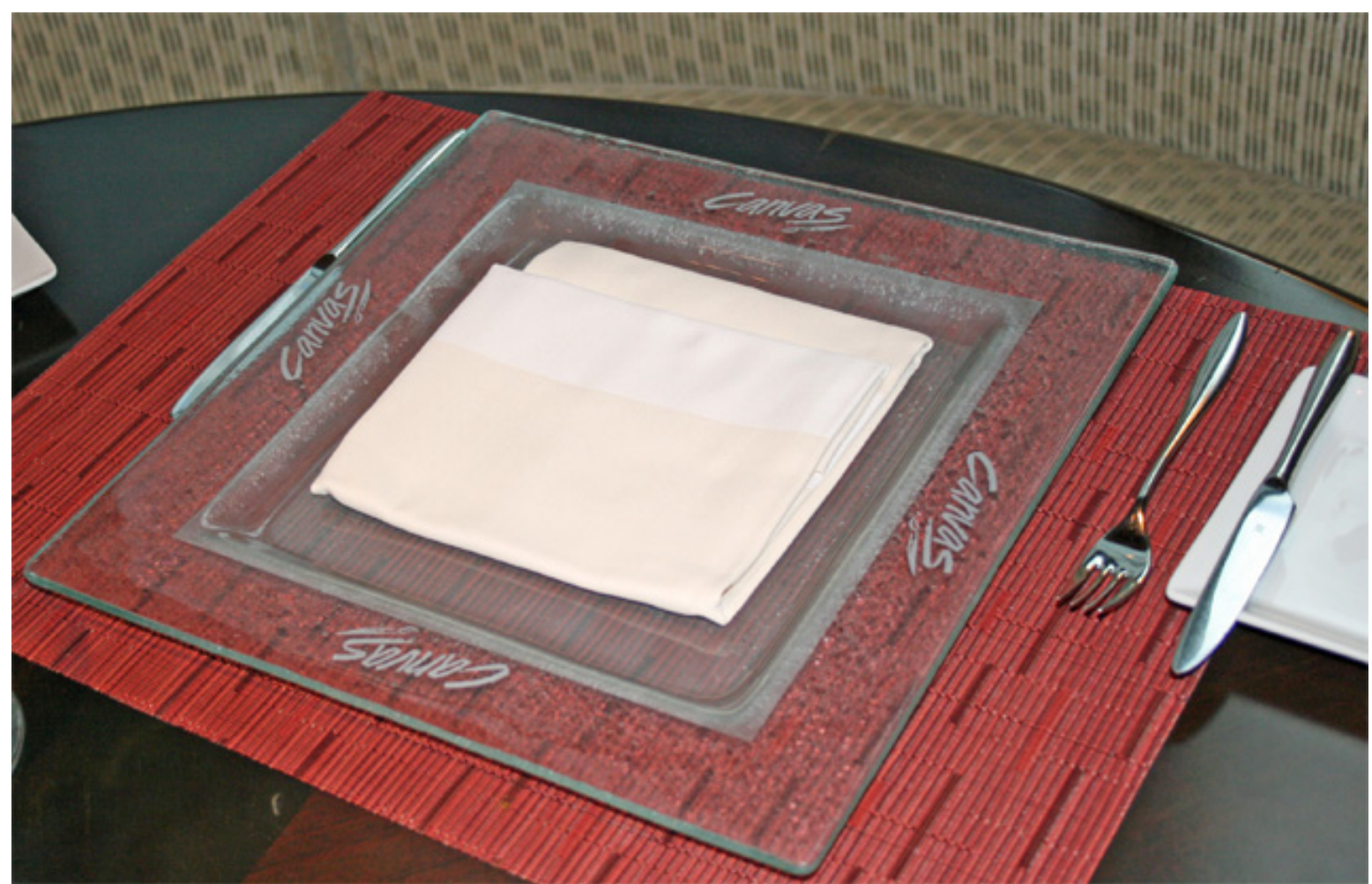

Fonte: foto tirada pelo autor, em visita realizada dia 19/11/2011 
A preocupação com os aspectos visuais do hotel fica mais clara nas palavras de CASTRO (2011):

"É incrivel essa coisa visual. No Canvas, por exemplo: um salmão que eu faço em casa, e que fica muito próximo do que é feito no restaurante, porque o chef já me deu várias receitas - se eu não coloco naquele prato, naquele momento, com aquele speech, ou seja, sem aquele contexto sensorial, não fica o mesmo salmão. No Canvas, que é uma "réplica” de uma galeria de arte, nós criamos algumas coisas para desenvolver este contexto: um garçom de bigode, outro com uma boina, um pintando quando alguém passar, etc... Ou seja, todo mundo lá é um pouco artista, inclusive os clientes, porque temos um quadro muito grande que os clientes, ao saírem, podem deixar sua marca ali, dando até mesmo um toque de interatividade."

A questão visual parece ter sido efetivamente planejada, ou seja, não ficou limitada a um simples projeto de decoração. O contexto criado para o restaurante é uma prova disto.

A preocupação em mostrar que o Hilton tem uma forte ligação com obras de arte não fica restrita ao restaurante Canvas e às peças que decoram o lobby. São vários os locais em que se podem ver diversas obras de arte decorando o hotel.

As ilustrações 47, 48 e 49 exemplificam isso mostrando, respectivamente, uma escultura que decora um dos andares, posicionada em frente aos elevadores, um dos quadros que decoram os corredores dos andares dos apartamentos, e uma das esculturas que decoram o lobby do hotel. 
Ilustração 47: foto de escultura nos corredores dos andares

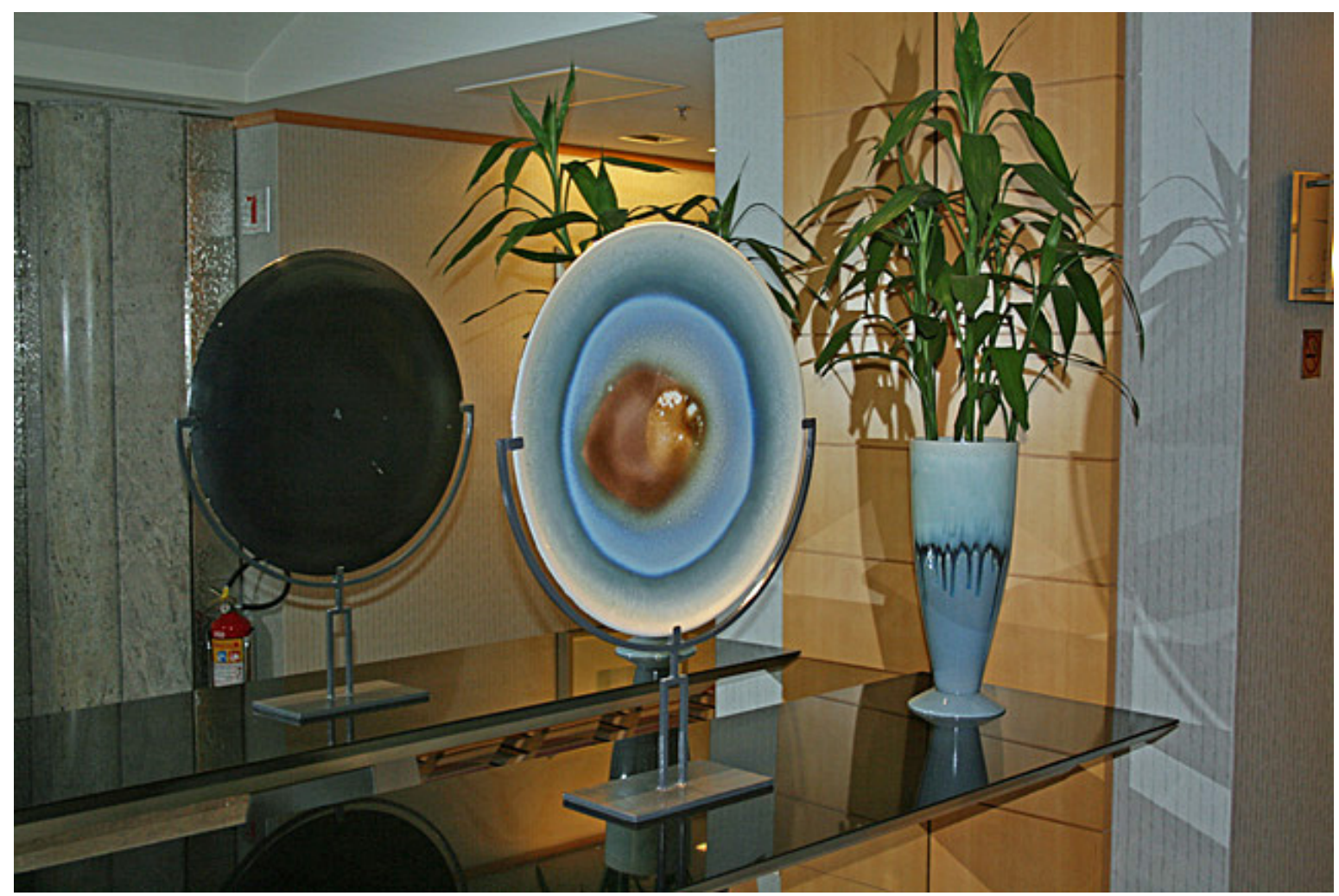

Fonte: foto tirada pelo autor, em visita realizada dia 19/11/2011

Ilustração 48: foto de quadro nos corredores dos andares

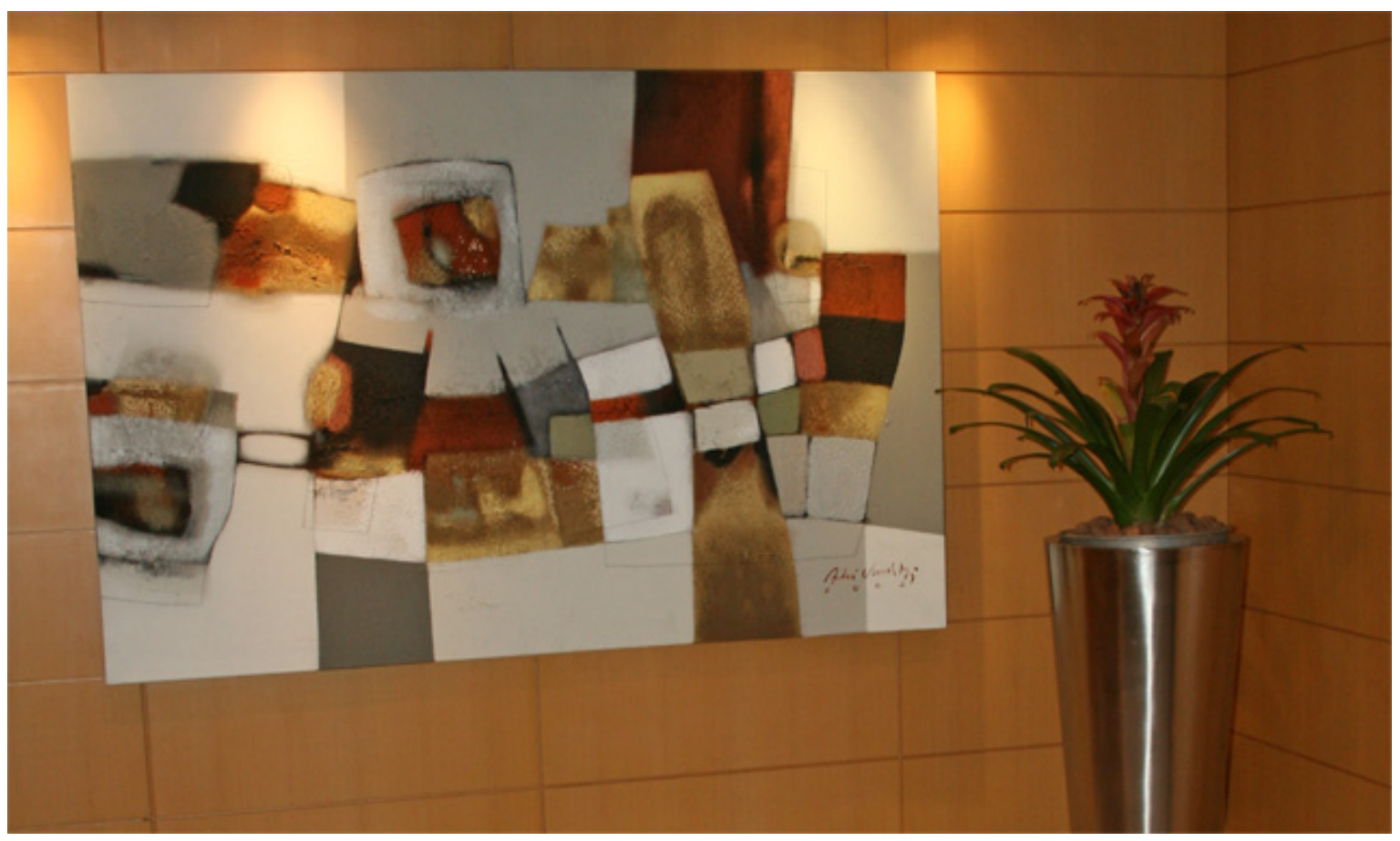

Fonte: foto tirada pelo autor, em visita realizada dia 19/11/2011 


\section{Ilustração 49: foto de escultura no lobby}

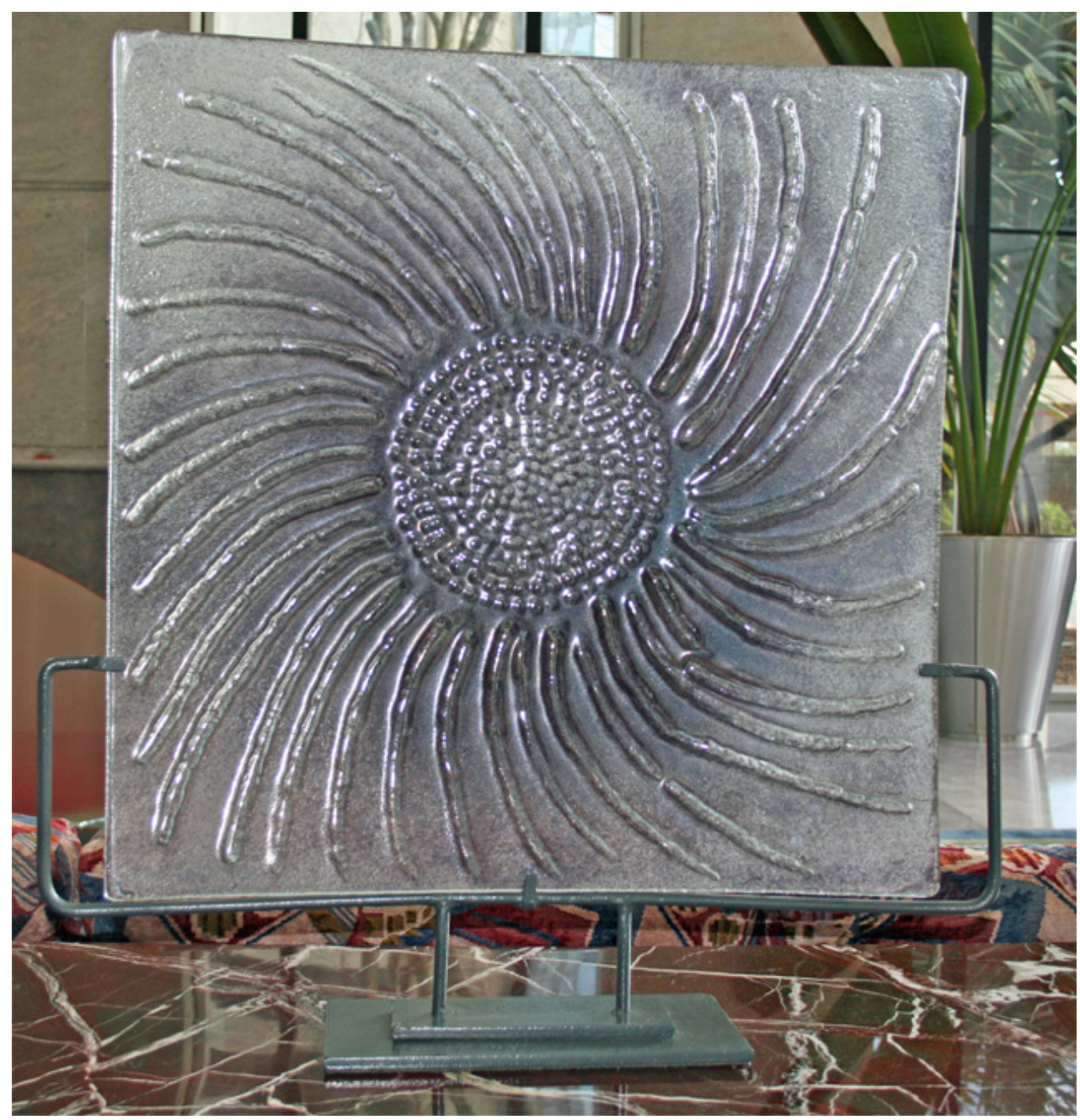

Fonte: foto tirada pelo autor, em visita realizada dia 19/11/2011

Como visto nas três ilustrações anteriores, o hotel divulga sua proximidade com arte em vários ambientes, preocupando-se sempre em expor objetos de arte moderna e contemporânea, para o posicionamento pretendido.

A gestão dos pontos de contato exige um trabalho constante com os detalhes. Por isso, chama a atenção positivamente o fato de que a preocupação estética não fica restrita às obras de arte e ao projeto arquitetônico do Hilton.

Esta preocupação também pode ser vista em outros pequenos detalhes, como destacado na ilustração 50, que mostra as lixeiras que ficam colocadas no hall dos elevadores, em todos os andares. Elas também tem um design diferenciado, e o material, aço inox, é o mesmo utilizado no revestimento da parede, reforçando o ar de modernidade do conjunto. 
Ilustração 50: Lixeira do hall dos andares

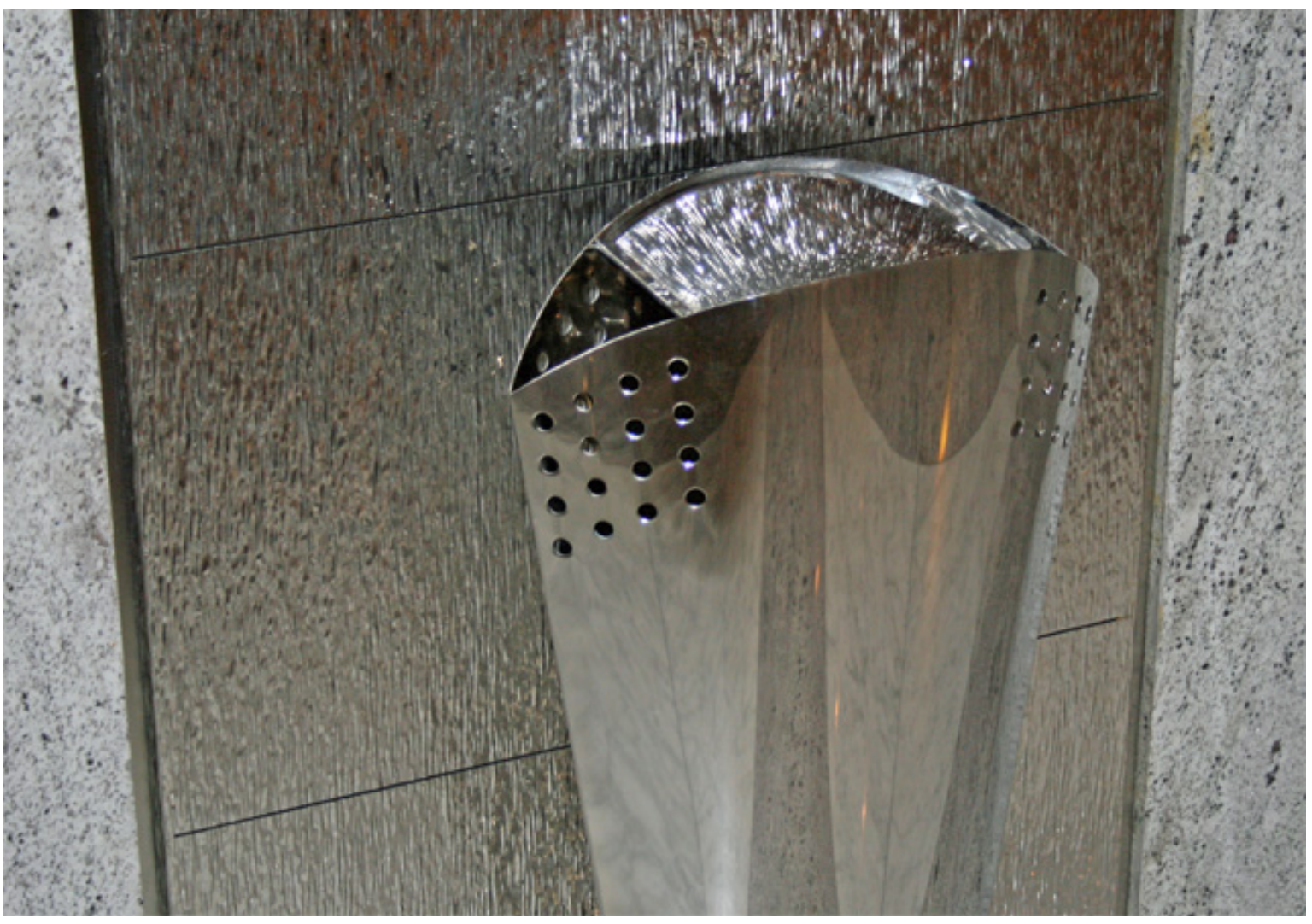

Fonte: foto tirada pelo autor, em visita realizada dia 19/11/2011

Evidentemente, se existe todo um trabalho estético desenvolvido em várias áreas do hotel, os quartos também receberam atenção especial neste quesito. Castro explica o projeto de layout dos apartamentos deixando clara esta preocupação:

"Fizemos pesquisas e descobrimos que dentro de apartamentos de hotéis as pessoas se sentem claustrofóbicas - quase nenhum hotel tem janela no banheiro. Aqui no Hilton, 70\% dos apartamentos tem banheiro com janela voltada para o próprio quarto, para minimizar essa sensação. Também fizemos uma decoração que divide o apartamento em 3 ambientes distintos: um para trabalhar, um para descansar e outro para se higienizar. É um conceito inovador, que foi muito bem aceito. Outro ponto em relação a isto: toda a suite tem 2 banheiros: um social e outro privativo. Isso porque muitas vezes o hóspede tem reunião dentro da suite, e não quer que algum participante da reunião use seu banheiro. São detalhes muito simples, mas que geram um conforto muito grande." (CASTRO, 2011) 
O layout e a decoração dos quartos, conforme explicado por Castro podem ser vistos nas ilustrações seguintes.

A ilustração 51 mostra a área de trabalho existente nos quartos. Nela, podem-se notar detalhes importantes como impressora, luminária, cadeira de escritório, mesa com água e garrafa de café. Além disso, a mesa de trabalho tem um pequeno anteparo de madeira. Isto serve para que o hóspede, ao se deitar, não tenha a visão das coisas que deixou na mesa de trabalho, como relatórios, pastas, notebook aberto, etc... Quando está deitado, o objetivo é que o hóspede se sinta na área de descanso, e esse tipo de detalhe ajuda nesta percepção.

Na ilustração 52 é visto a área de descanso, com a cama já com o serviço de turndown feito. Pode-se perceber que a forma como a cama está arrumada, com o edredom esticado e os travesseiros cuidadosamente dispostos tem o objetivo de passar a imagem de algo relaxante, confortável. Para isso, os tons claros e pastéis usados acabam sendo fundamentais.

\section{Ilustração 51: Área de trabalho dos quartos}

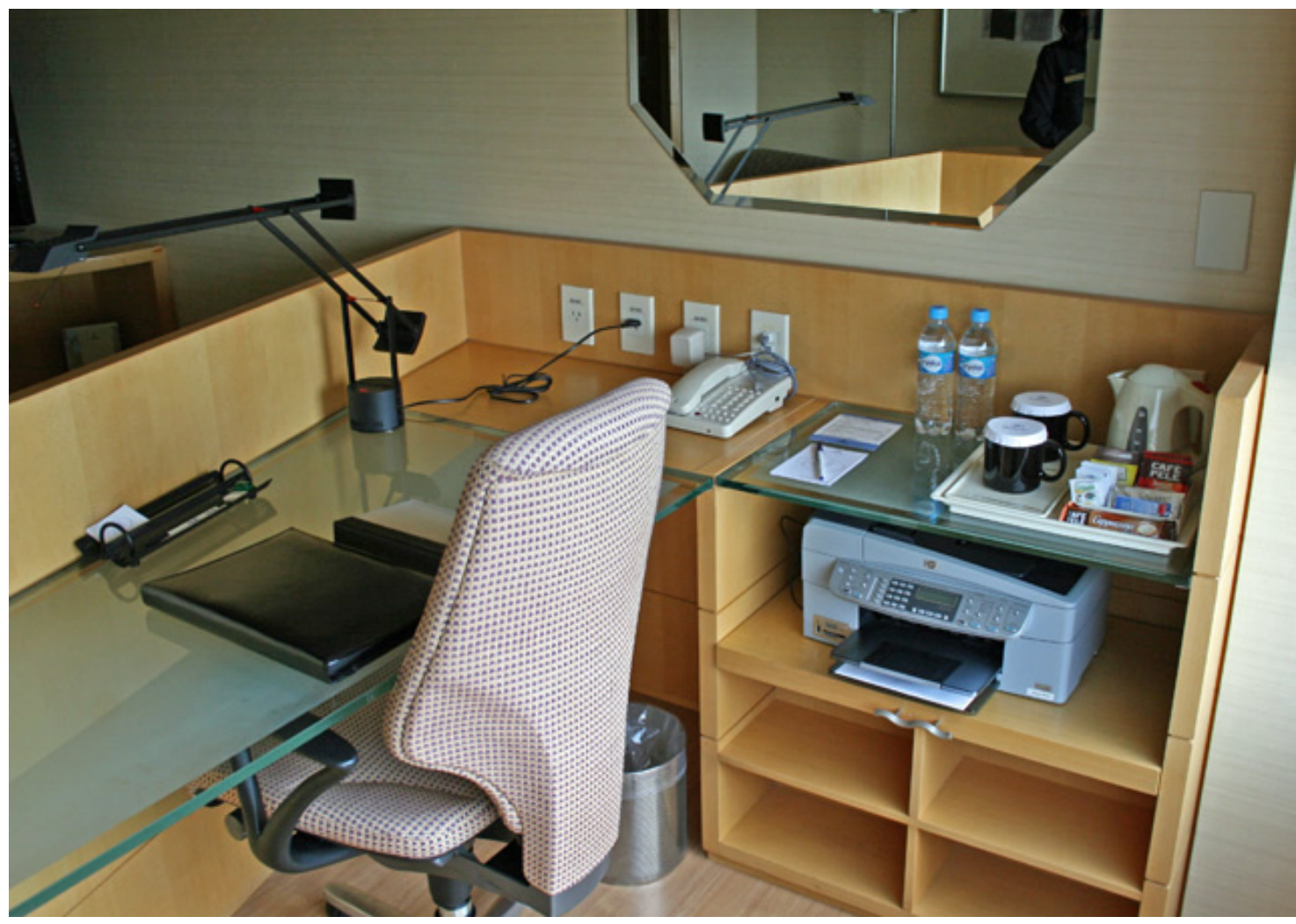

Fonte: foto tirada pelo autor, em visita realizada dia 19/11/2011 


\section{Ilustração 52: Área de descanso do quarto}

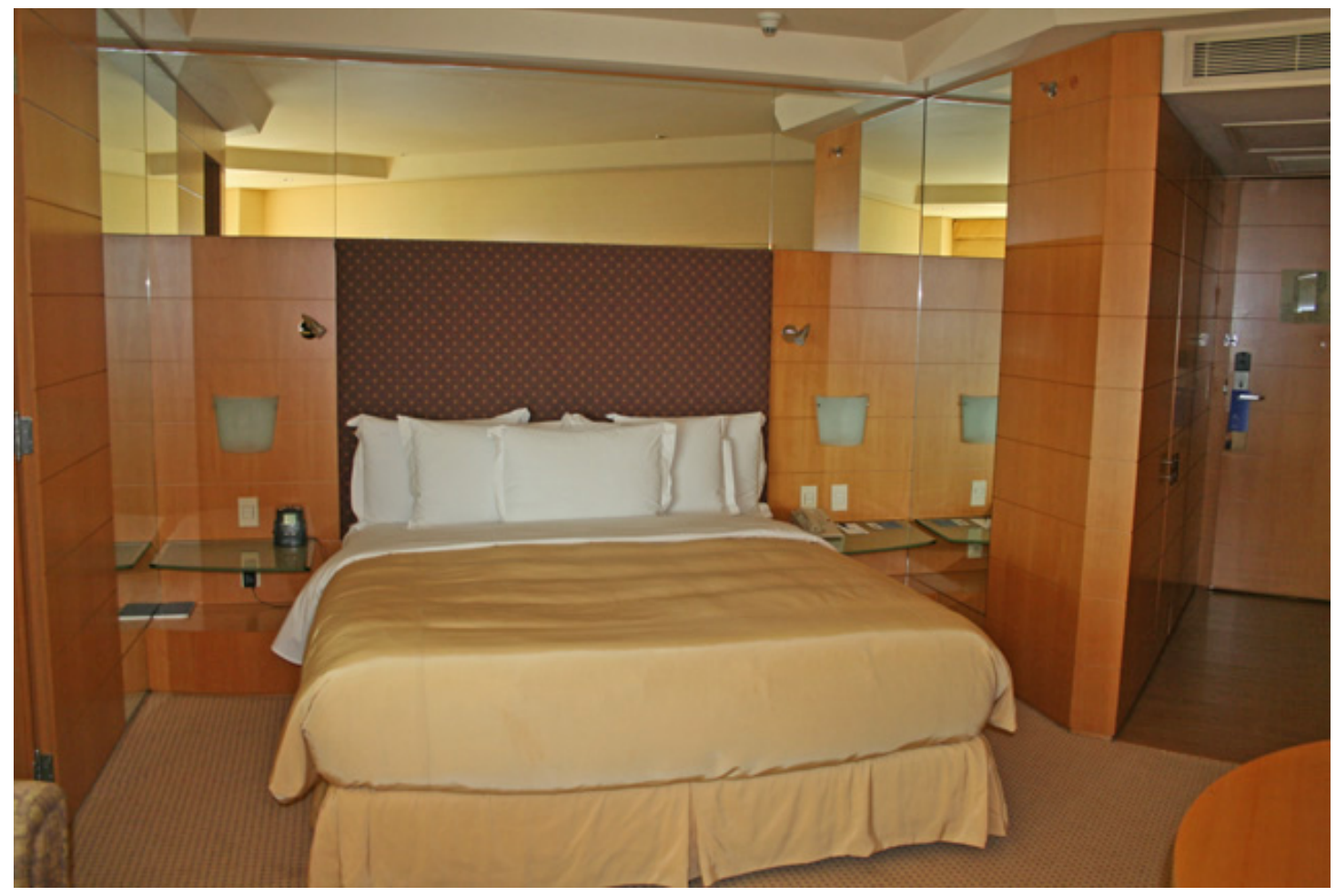

Fonte: foto tirada pelo autor, em visita realizada dia 19/11/2011

Finalmente, em relação aos funcionários, existe a mesma preocupação estética já analisada no hotel Hyatt, ou seja, as roupas dos funcionários tem que ser sóbrias, discretas e elegantes.

Também no Hilton não é permitido nenhum tipo de ousadia como piercings e tatuagens aparecendo, mulheres com maquiagem forte ou unhas coloridas e homens com brincos ou cabelo comprido.

Todas as questões abordadas sobre os aspectos visuais do Hilton, em especial o conceito de modernidade, fugindo um pouco dos projetos mais clássicos da hotelaria de luxo representam, na opinião de Castro (2011) uma mudança importante. Segundo ele, "saímos de uma hotelaria onde o gerente-geral usava um terno de flanela, e hoje em dia talvez nem use mais terno. Hoje em dia é Paris Hilton. Passamos da flanela para a Paris Hilton.”

Em que pese a analogia da vestimenta feita pelo executivo ainda estar um pouco longe da realidade do hotel que, como visto, ainda exige que os funcionários se vistam seguindo os padrões da hotelaria, é fato que a concepção estética do Hilton difere do tradicional e aponta mais para a imagem de modernidade proposta no seu posicionamento. 


\section{Olfato}

Castro (2011) informa que, com relação ao olfato, não existe o uso de nenhum aroma para o hotel. No exterior, a rede Hilton utiliza dois aromas próprios, mas o Hilton São Paulo ainda não utiliza nenhum dos dois, porque ainda não conseguiram chegar a nenhuma fragrância que seja unânime. Portanto, no sentido do olfato, não existe nada feito por parte do hotel.

Obviamente, como mostrado no hotel Hyatt, também no Hilton existem recomendações para os funcionários: os desodorantes devem ser neutros, e não devem usar perfumes muito fortes. Além disso, o Hilton se responsabiliza pela lavagem de todos os uniformes, para garantir a qualidade exigida na aparência e perfume.

Este ponto chama a atenção, pois a preocupação demonstrada pelo Hilton na gestão dos aspectos visuais nem de longe é repetida no sentido do olfato que, como apontado no referencial teórico, é um dos sentidos mais facilmente percebido pelo ser humano.

Essa falta de atenção fica ainda mais evidente quando se observa que o Hilton internacional já desenvolveu aromas próprios, e que estes ainda não foram adotados no hotel de São Paulo por razões absolutamente locais e, no mínimo questionáveis, pois como afirmou Castro, ainda não se chegou a uma unanimidade. Este discurso contraria a afirmação inicial da impossibilidade de se agradar a todos, e demonstra a perda de algumas oportunidades em termos de ferramenta de marketing.

\section{Tato}

A questão do tato parece ter ações bastante similares às do Hyatt em relação ao enxoval: os lençóis também são de algodão de 600 fios, as toalhas devem ser macias, e os travesseiros são feitos com pluma de ganso. Toda roupa de cama do Hilton é importada do Paquistão ou do Egito, considerados os melhores fabricantes mundiais nesta área.

Na ilustração 53 observa-se o detalhe da maciez das toalhas de banho, que é a mesma dos roupões. Roupa de banho macia e felpuda é um dos itens considerados fundamentais em relação ao enxoval do hotel. 


\section{Ilustração 53: Toalhas de banho}

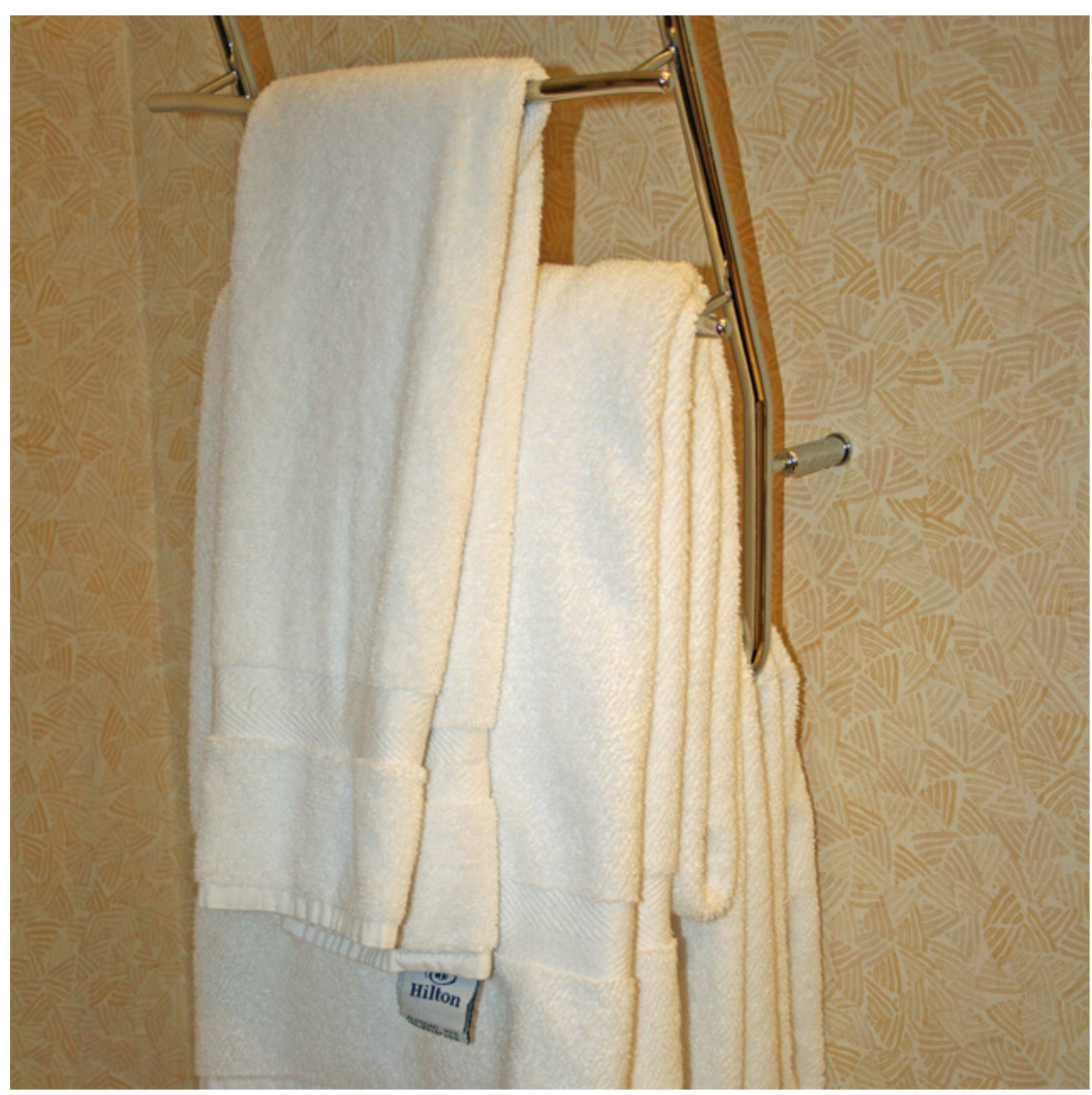

Fonte: foto tirada pelo autor, em visita realizada dia 19/11/2011

Com relação aos amenities, os critérios são rígidos e padronizados mundialmente. Boa parte dos produtos é desenvolvida especificamente para o Hilton pela Bath \& Body Works, uma grande empresa de cosméticos dos EUA. Alguns itens, no entanto, são nacionais, como mostra a ilustração 54, com produtos da Mahogany que, no entanto, devem ter a embalagem no mesmo layout dos outros produtos.

A Mahogany também é uma marca de produtos de higiene pessoal de boa qualidade, mas os produtos por ela fornecidos ao Hilton são produtos de sua produção tradicional, ou seja, reforça a afirmação que o olfato não foi pensado para este ponto. Pode-se dizer que a preocupação fica restrita ao sentido do tato, na medida em que oferece produtos para tratamento e hidratação corporal. 


\section{Ilustração 54: Amenities com itens nacionais}

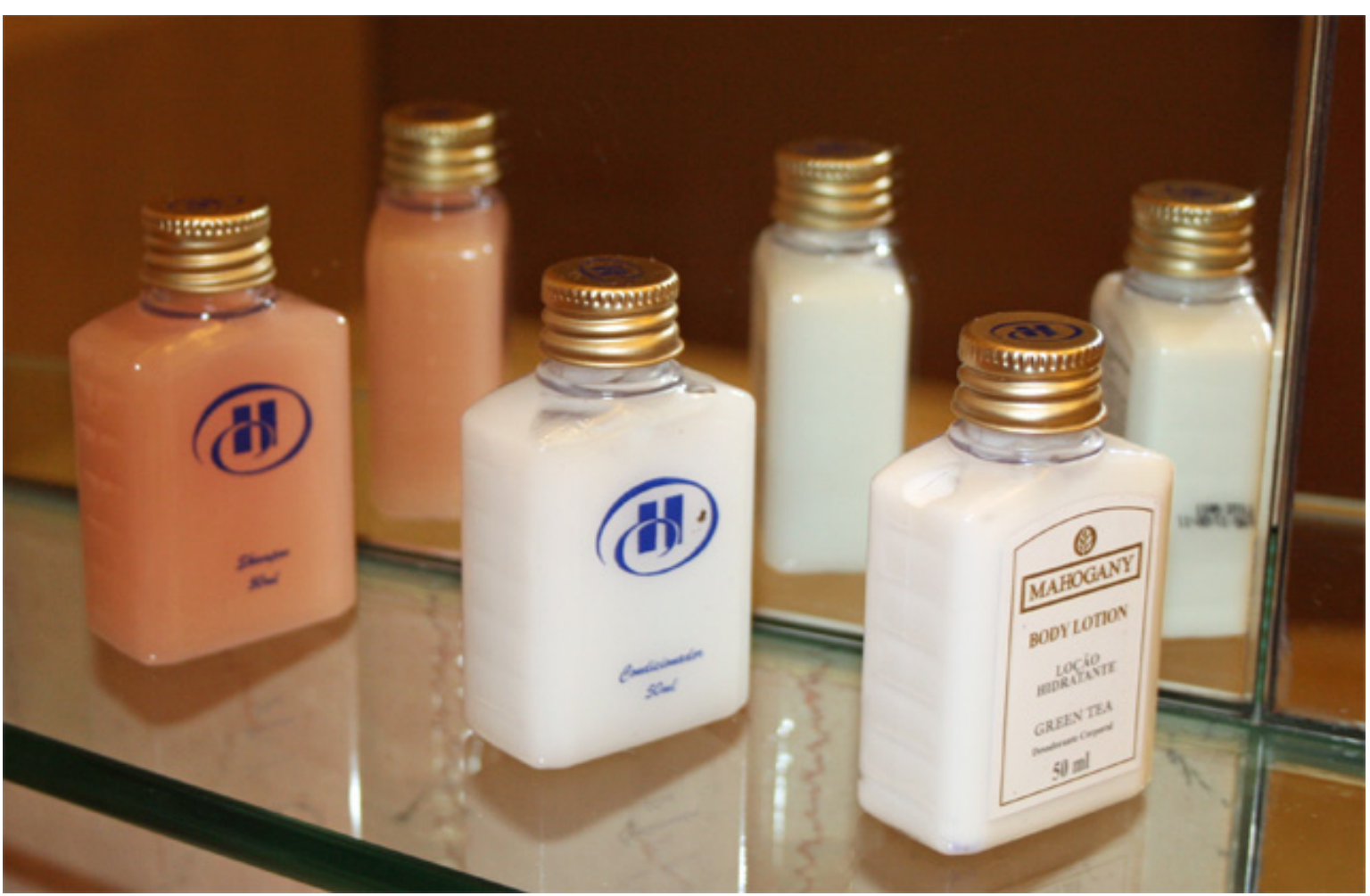

Fonte: foto tirada pelo autor, em visita realizada dia 19/11/2011

Um ponto interessante que chama a atenção, como já citado, é a preocupação existente dentro dos quartos na separação entre a área de trabalho e a área de descanso. Este detalhe gerou uma adequação nos tipos de piso, havendo uma distinção entre a área de trabalho (madeira) e a área de descanso (carpete).

Evidentemente, isso também causa uma sensação tátil diferente, pois a sensação de um piso de madeira em contraste com um piso de carpete auxilia para que a percepção entre área de descanso e área de trabalho fique mais acentuada. Essa preocupação com a decoração e a diferença nos pisos pode ser vista na ilustração 55 . 


\section{Ilustração 55: Áreas de descanso e trabalho}

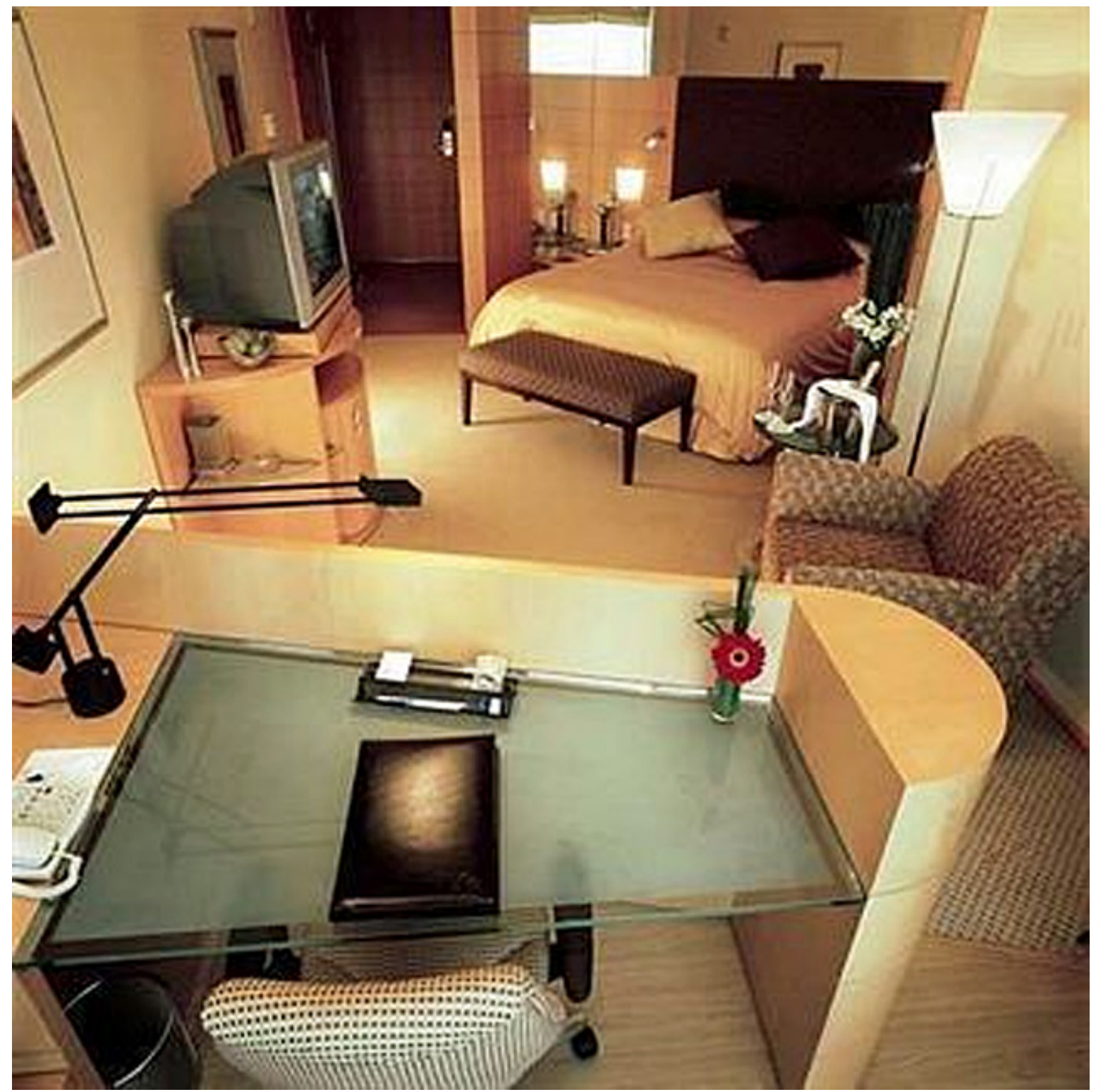

$\mathrm{Na}$ questão do tato merece destaque a temperatura do hotel, que está sempre regulada em $21^{\circ} \mathrm{C}$. Nos quartos, os aparelhos de ar-condicionado são digitais, permitindo que o hóspede escolha a temperatura de sua preferência.

\section{Paladar}

O sentido do paladar também é trabalhado em algumas ações. De início, pode-se citar o cardápio dos restaurantes, elaborados de forma a sempre oferecerem uma opção de comida vegetariana e comida kosher. 
No frigobar, segundo Castro (2011), existem itens que não podem faltar, como água mineral e Coca-Cola, além do guaraná, que os estrangeiros querem sempre experimentar. Além destas, o frigobar também é abastecido com diversos tipos de bebidas, como vemos na ilustração 56, para agradar diferentes preferências. Para isso há um mix que inclui cervejas, refrigerantes, sucos, achocolatados, vodka e água de coco. A maior parte das bebidas são marcas comercializadas pela Coca-Cola.

Ilustração 56: Frigobar

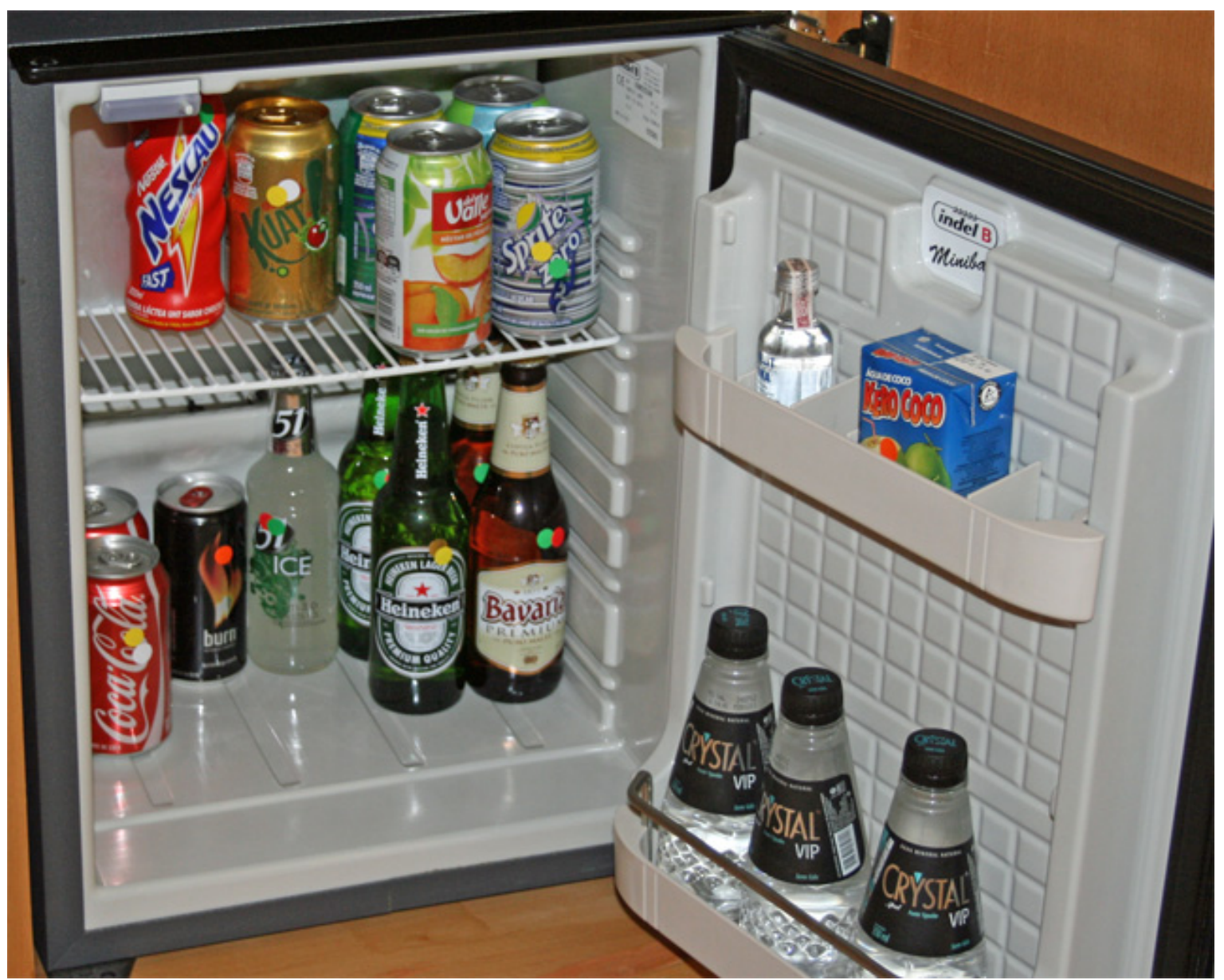

Fonte: foto tirada pelo autor, em visita realizada dia 19/11/2011

A ilustração 57 mostra uma foto do móvel com os produtos que complementam a oferta dos itens do frigobar. Nota-se a oferta de outras opções de bebidas, como whisky, licor e cachaça brasileira, dando um toque nacional no item paladar. Este toque é reforçado pelos itens comestíveis, onde vemos castanha de caju e biscoitos de castanhas do Pará, com a marca da Amazônia. 
O mix de snacks oferecidos procura buscar um equilíbrio entre doces e salgados, atentando para que não se repita nenhum sabor. No entanto, vemos que o mix destes snacks tem uma quantidade e diversidade bem menor que o mix de bebidas.

\section{Ilustração 57: Snacks e bebidas dos quartos}

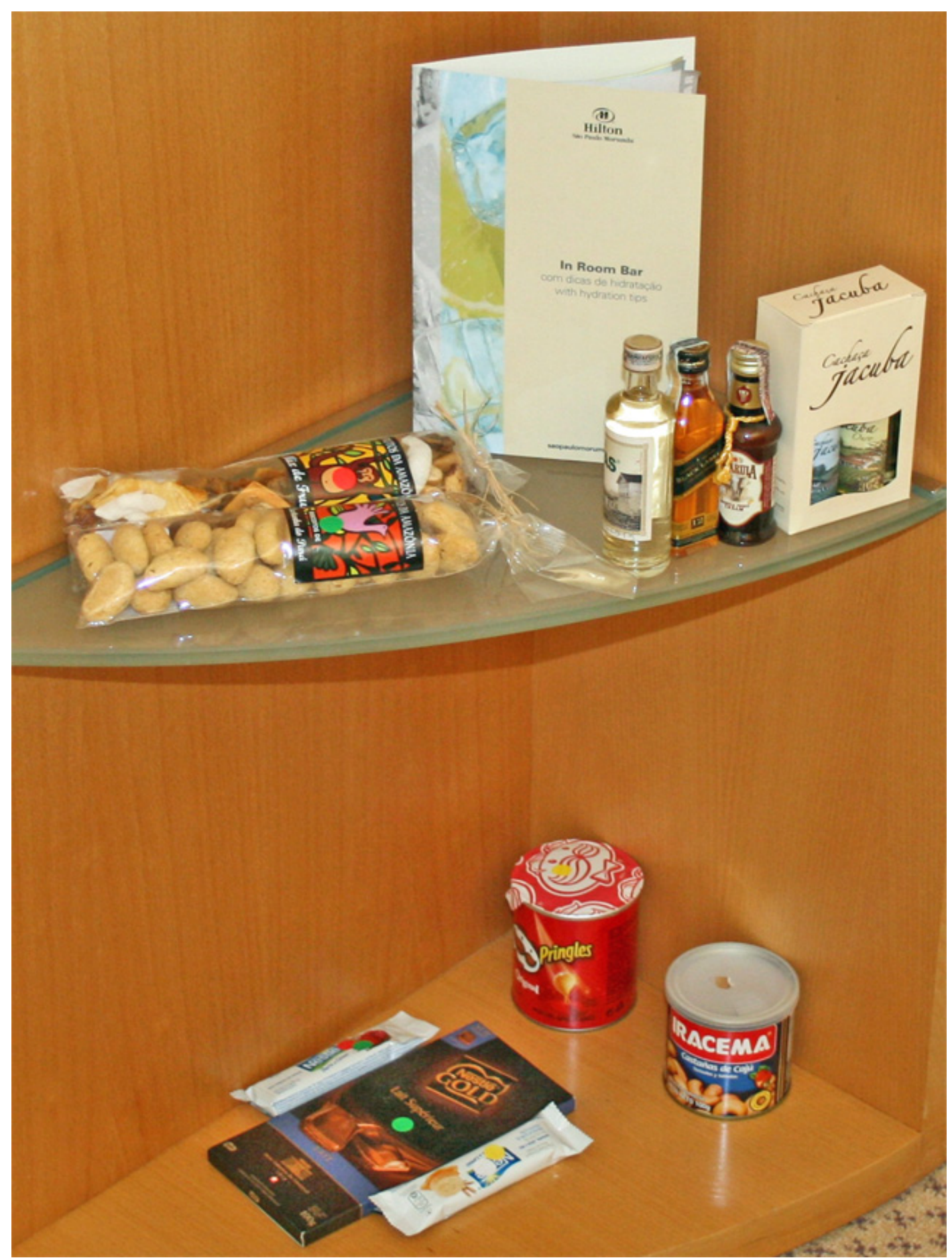

Fonte: foto tirada pelo autor, em visita realizada dia 19/11/2011 
O Hilton chegou a oferecer drinks de boas-vindas, mas desistiu da ideia quando percebeu que os hóspedes queriam fazer check-in rapidamente e irem para seus apartamentos - ou seja, os drinks oferecidos não agregavam nenhum valor.

Além disso, oferecer drinks no momento do check in num hotel deste porte é uma operação um pouco mais complexa do que pode parecer. Isto porque grande parte dos check ins e check outs são feitos no final da manhã, gerando um considerável movimento de pessoas no lobby e na recepção do hotel.

Com isso, para que todos os hóspedes fossem agraciados com um drink, deveria existir um processo bem integrado entre a área de recepção e a área de alimentos e bebidas. Segundo CASTRO (2011), este processo tinha um grau de complexidade e custo que não se justificava frente ao baixo valor que agregava.

Por outro lado, o sentido do paladar é aguçado a noite, quando os hóspedes encontram em seus apartamentos um kit de chocolate desenvolvido em parceria com a empresa Chocolat du Jour, conforme vemos nas ilustrações 58 e 59.

É um kit que oferece três pequenos doces de chocolate, com diferentes sabores, numa caixa desenvolvida especialmente para isso e fabricado, como citado, por uma empresa (Chocolat du Jour) cuja marca é percebida como sendo de alta qualidade.

De certa forma, este brinde supre um pouco a pequena oferta de snacks que existe nos apartamentos. 
Ilustração 58: Kit chocolate 1

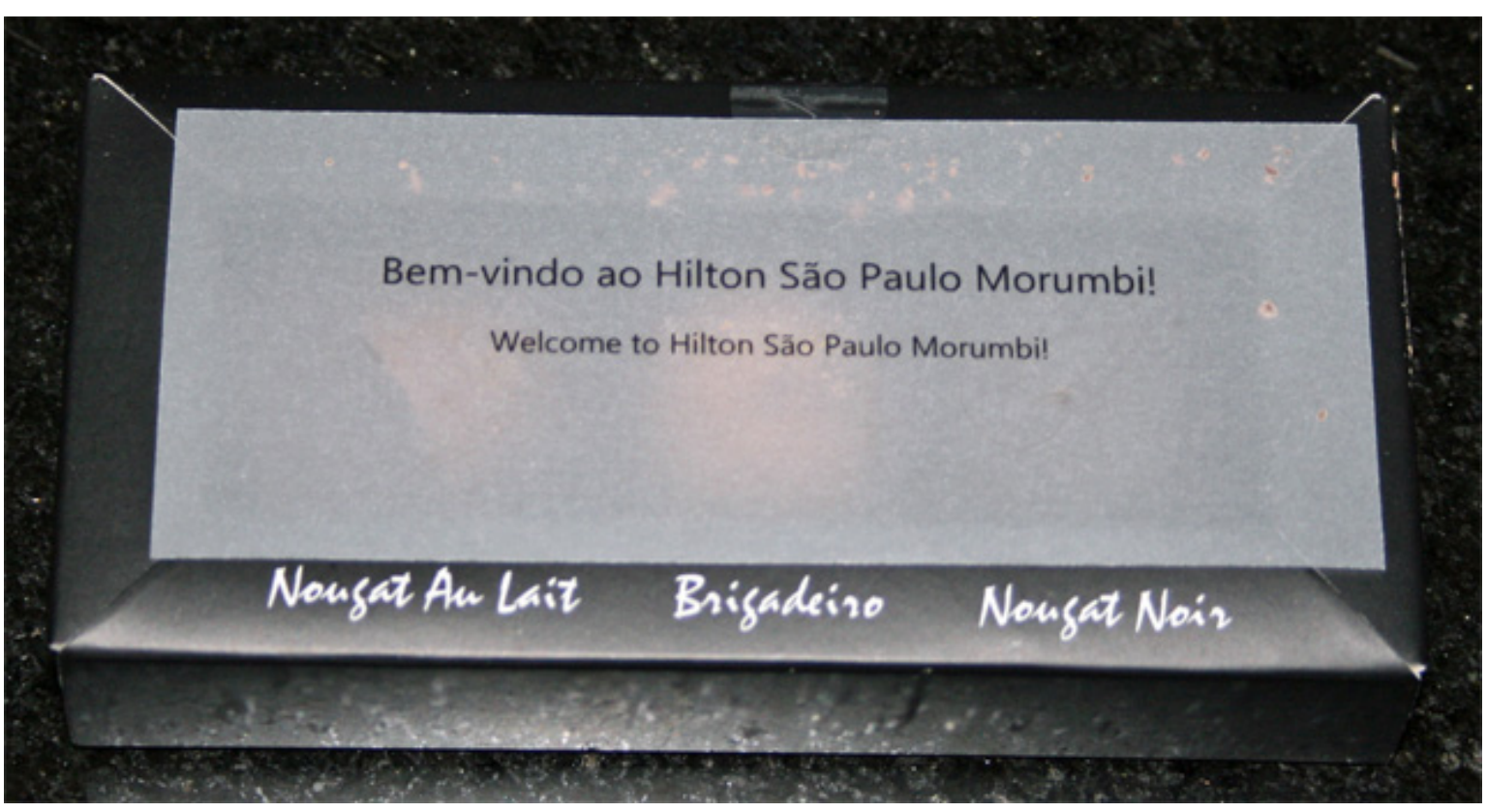

Fonte: foto tirada pelo autor, em visita realizada dia 19/11/2011

Ilustração 59: Kit chocolate 2

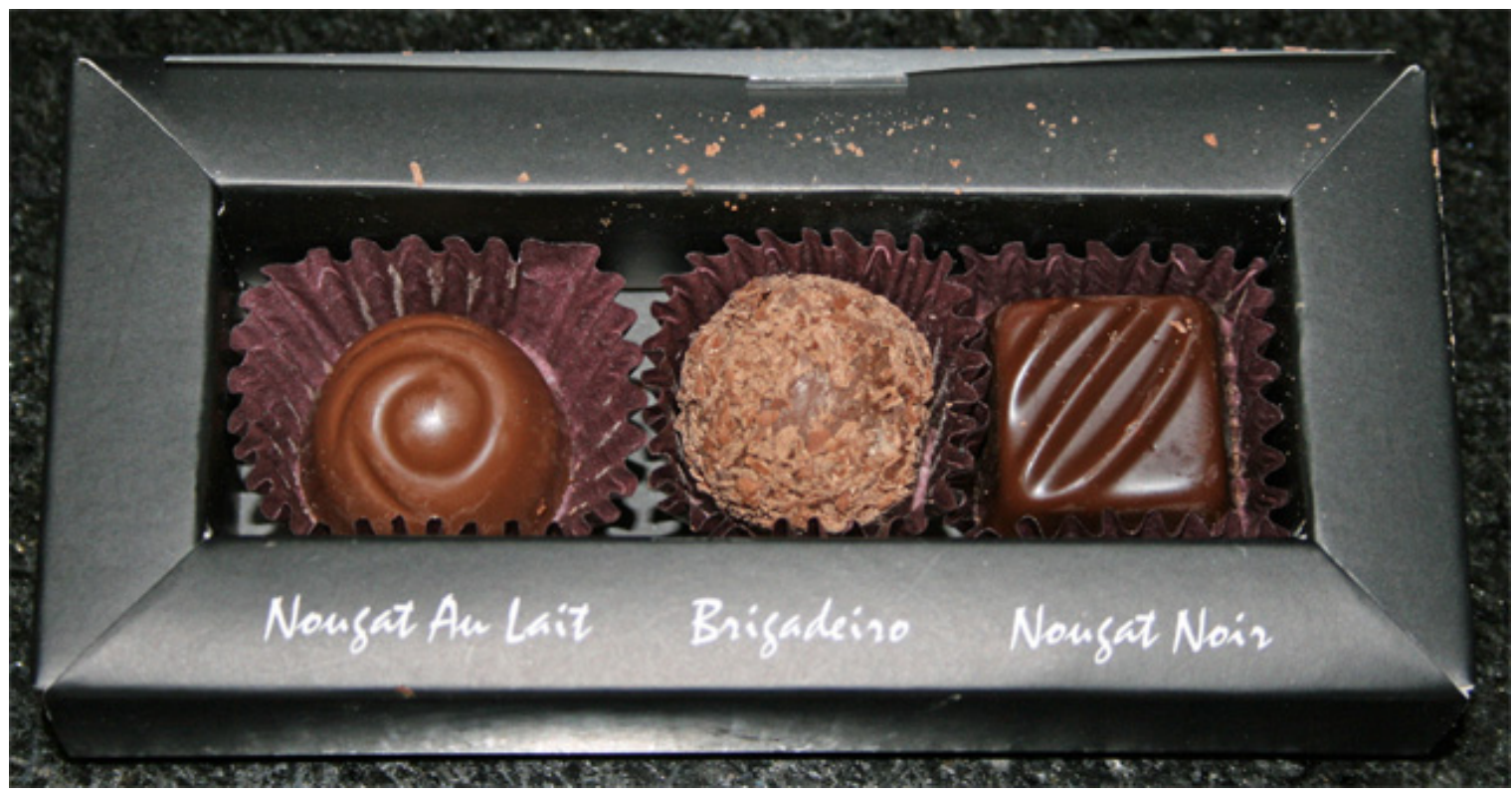

Fonte: foto tirada pelo autor, em visita realizada dia 19/11/2011

Em relação ao paladar, o Hilton também desenvolveu mais dois itens que são oferecidos a alguns hóspedes especiais: os mais frequentes, os que tiveram algum problema com o hotel, e aqueles que geram mais receita. Estes itens também são usados como material promocional pela equipe de vendas, que distribui para clientes e prospects nas visitas que realiza. 
Um dos itens é chamado Choco Cinno, que é um kit composto de três tipos de barras de chocolate, também com diferentes sabores, que devem ser mergulhadas em leite quente para que derretam, obtendo-se assim uma xícara de chocolate quente. O kit é feito com chocolate importado da Bélgica, cuja qualidade é melhor, pois se utiliza de pouca gordura, o que facilita o processo de derretimento. As ilustrações 60 e 61 mostram um exemplo desse kit, que são embalados numa caixa que segue o mesmo padrão visual da caixa que embala os chocolates colocados nos apartamentos.

\section{Ilustração 60: Kit Choco Cinno 1}

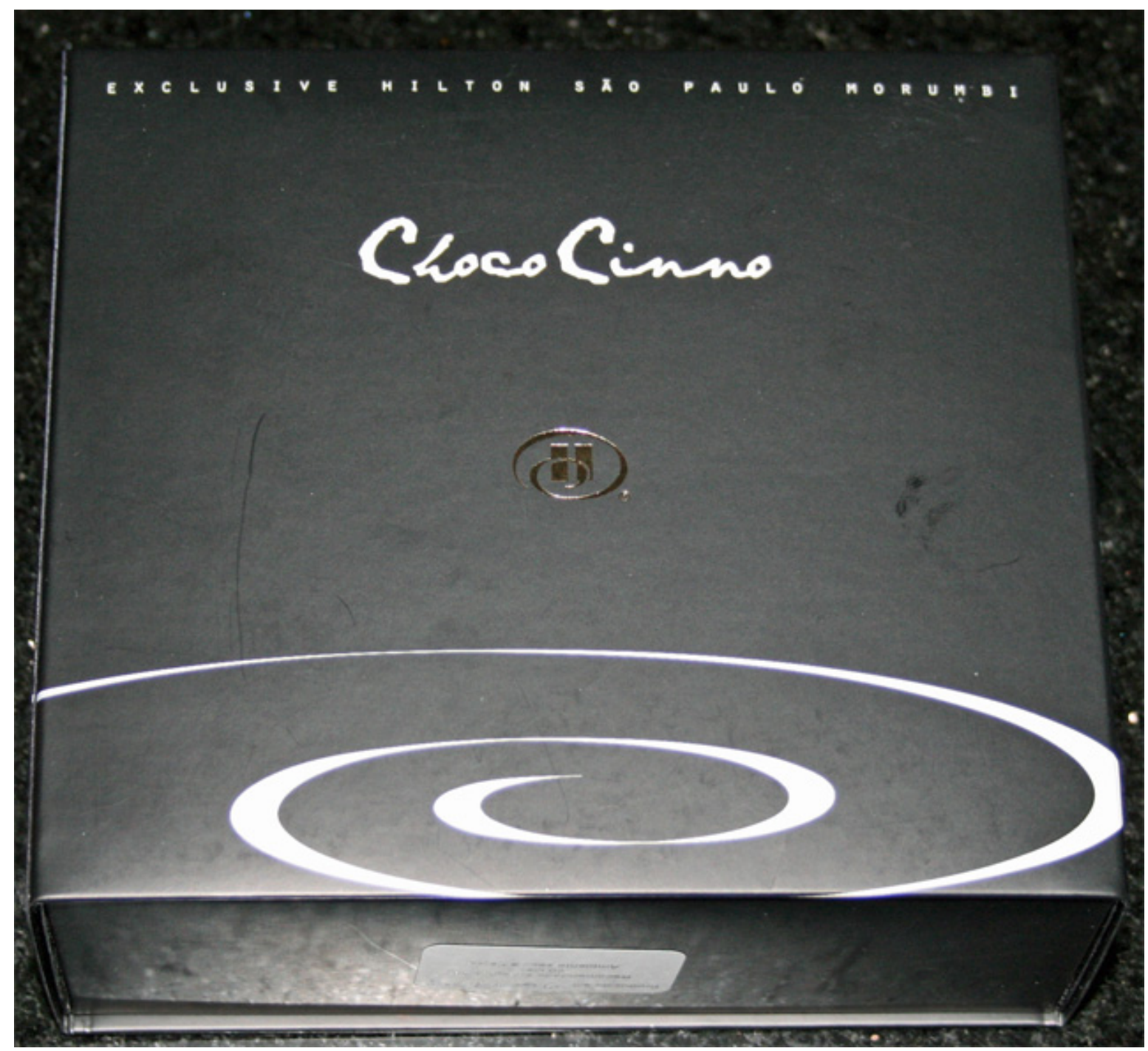

Fonte: foto tirada pelo autor, em visita realizada dia 19/11/2011 


\section{Ilustração 61: Kit Choco Cinno 2}

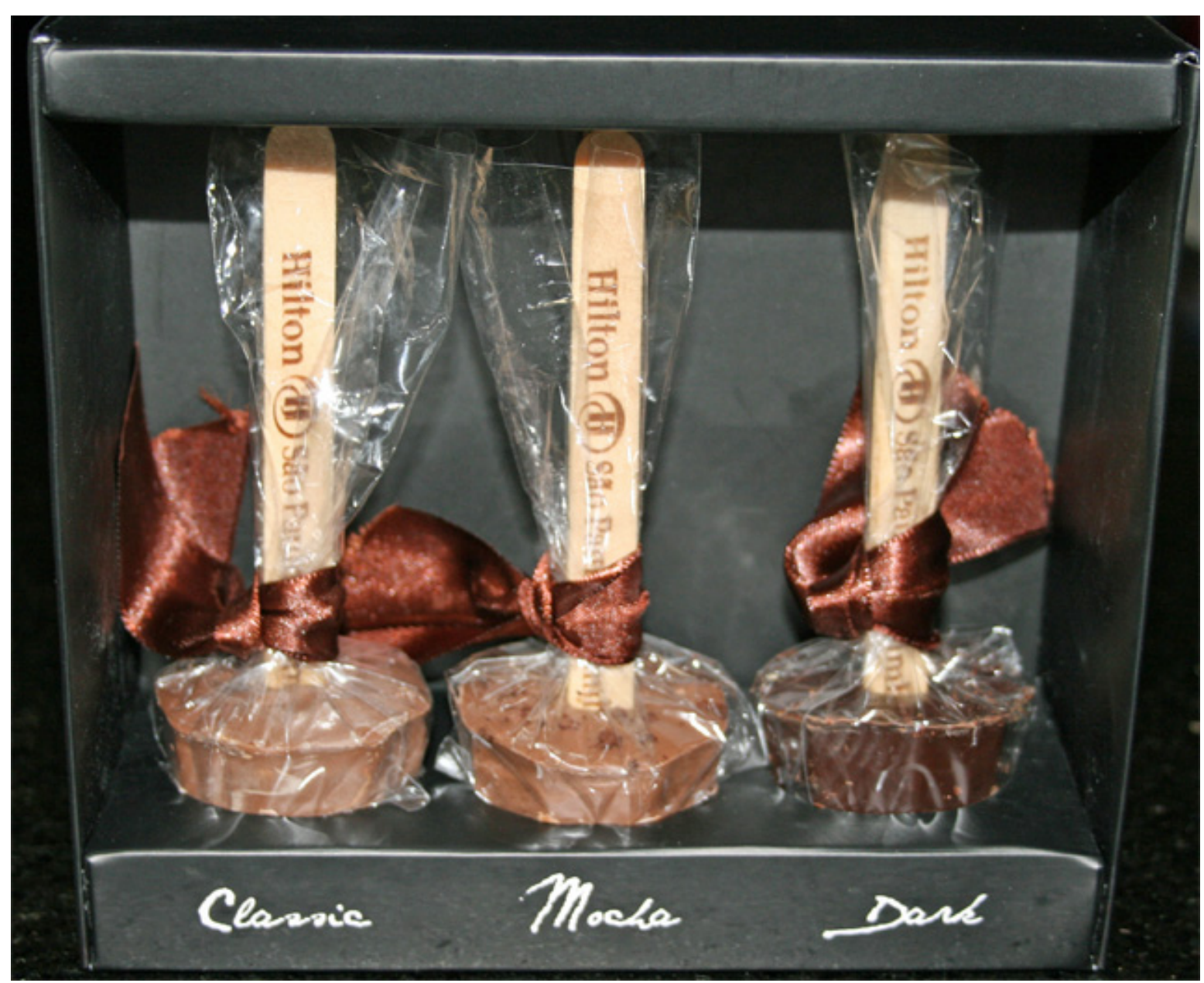

Fonte: foto tirada pelo autor, em visita realizada dia 19/11/2011

Além do Choco Cinno, o hotel desenvolveu outro presente ligado ao sentido do paladar, chamado de Hilton Chili Peppers. Este produto é um kit contendo 3 tipos de pimentas brasileiras, como visto nas ilustrações 62 e 63 .

Este kit vem embalado numa caixa com o mesmo padrão estético dos outros brindes, e é oferecido como lembrança para hóspedes selecionados. 


\section{Ilustração 62: Hilton Chili Peppers 1}

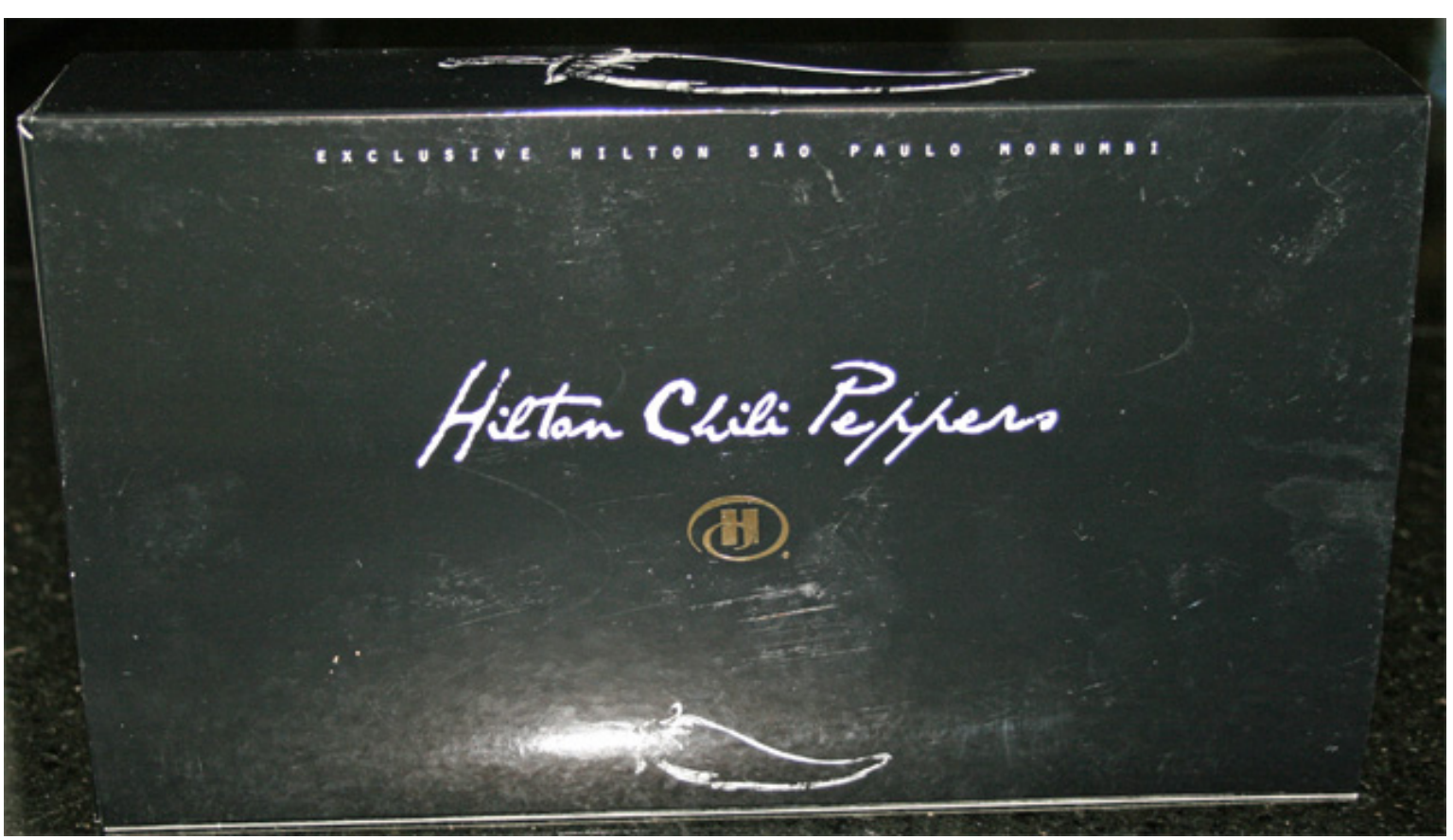

Fonte: foto tirada pelo autor, em visita realizada dia 19/11/2011

\section{Ilustração 63: Hilton Chili Peppers 2}

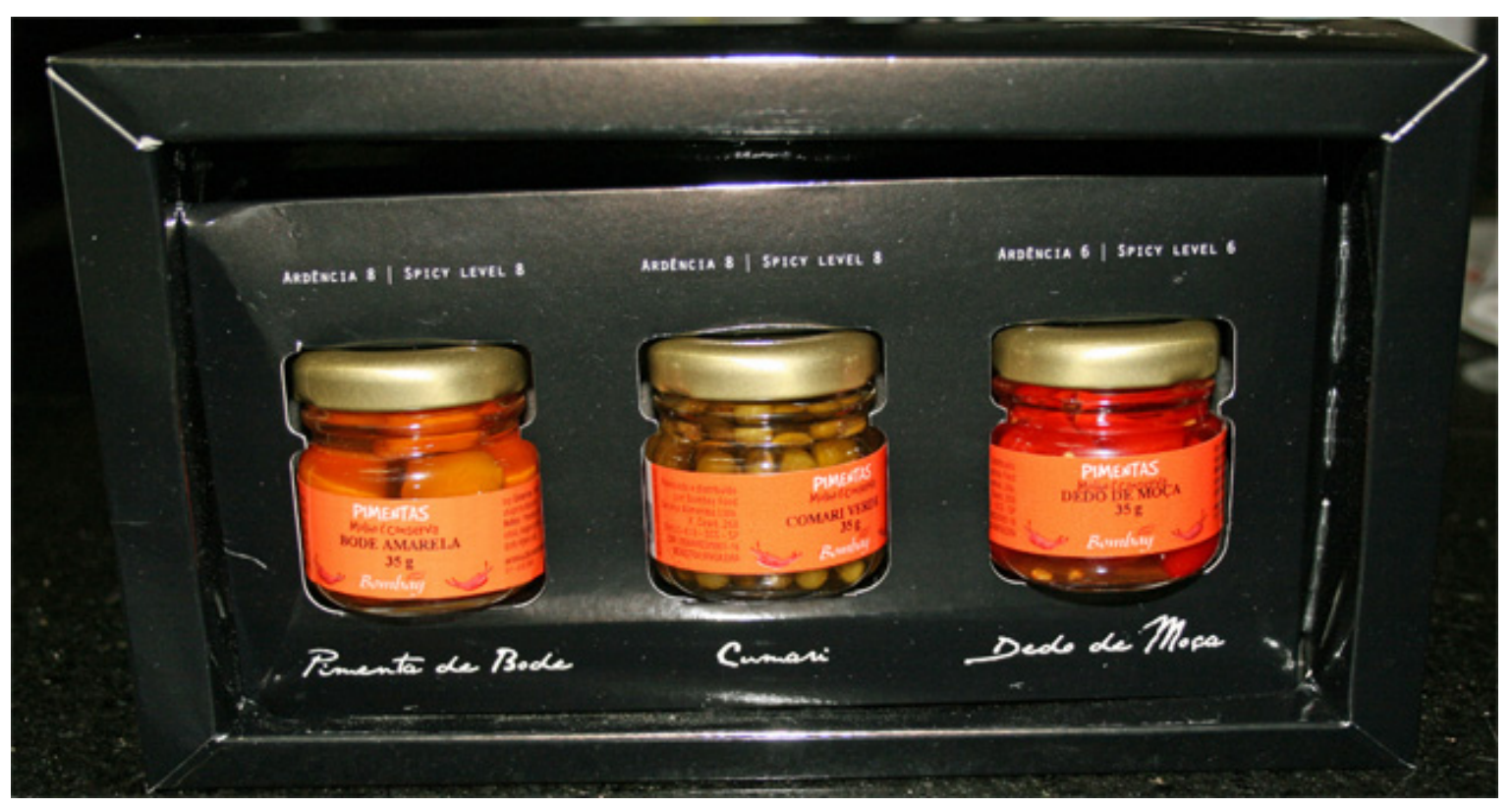

Fonte: foto tirada pelo autor, em visita realizada dia 19/11/2011

Finalmente, da mesma maneira que no Hyatt, no Hilton também existe uma grande adega, localizada na entrada do restaurante Canvas, e que acomoda uma enorme variedade de bebidas, especialmente os vinhos. 
A ilustração 64 mostra uma parte desta adega. Pode-se observar que também é feita com materiais como ferro e vidro, acompanhando a linguagem do restaurante, como já explicado. Pelo seu porte e design, esta adega também provoca o paladar dos clientes do restaurante, principalmente por deixar visível uma grande quantidade e diversidade de bebidas.

Novamente os elementos visão e olfato são trabalhados de maneira conjunta.

\section{Ilustração 64: Adega do Restaurante Canvas}

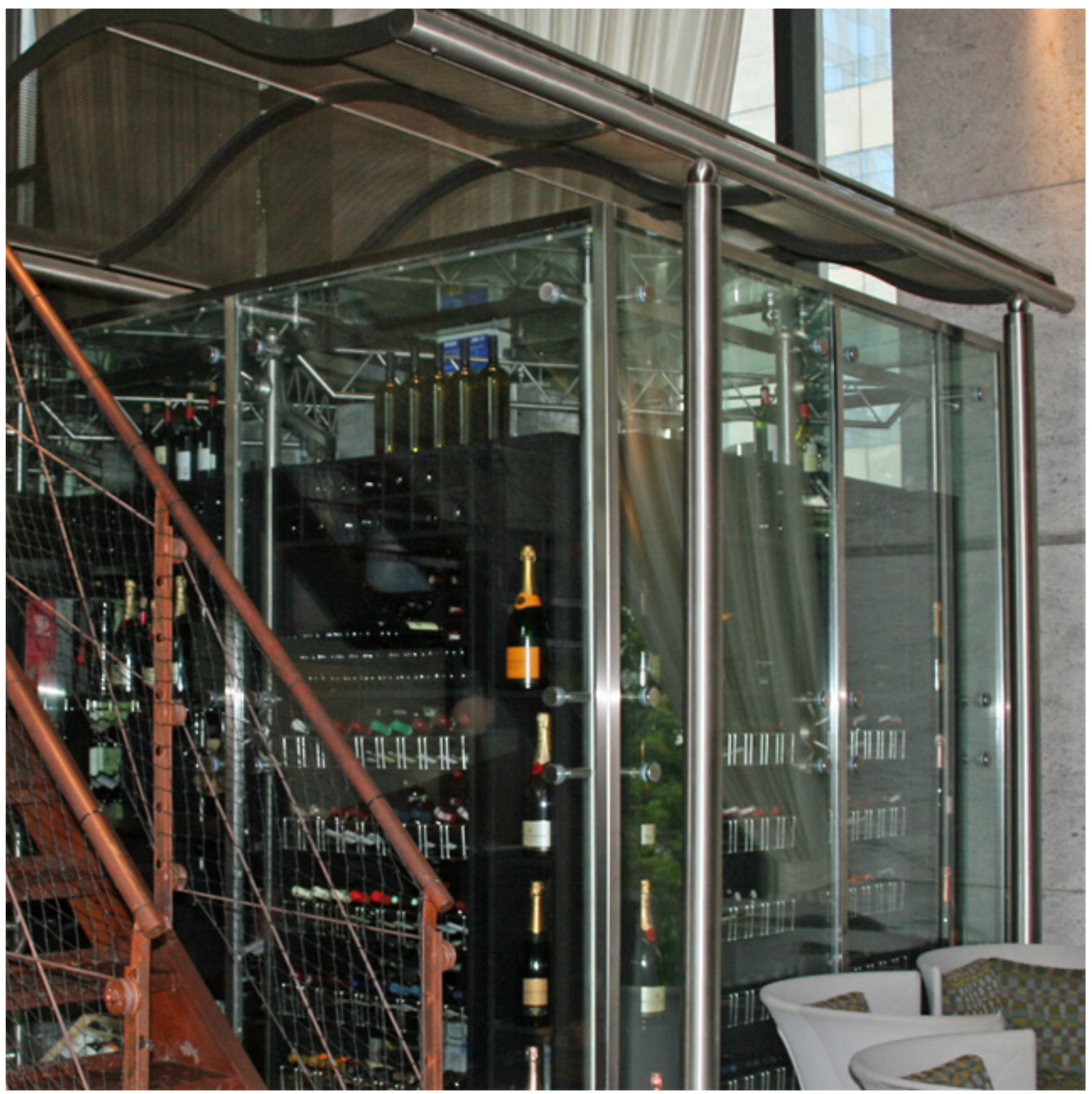

Fonte: foto tirada pelo autor, em visita realizada dia 19/11/2011 


\section{Audição}

Em relação ao sentido da audição, CASTRO (2011) coloca que, apesar de achar importante, o hotel não tem nada neste quesito, nem mesmo em termos de música ambiente.

O que existe é apenas um tratamento acústico sofisticado no centro de convenções, para que o evento de uma empresa não atrapalhe o evento de outra.

O hotel também desenvolveu um script básico para os funcionários, que devem sempre perguntar ao hóspede: “o que mais posso fazer por você?” Esta pergunta pretende mostrar aos hóspedes a disposição dos funcionários em servir e oferecer um bom tratamento durante a estadia.

O fato da pergunta fazer parte de um script objetiva reforçar este conceito e, através da repetição, criar uma espécie de "marca registrada" do hotel, gerando uma boa memória auditiva.

As respostas dos hóspedes são anotadas em blocos e, depois de analisadas e tabuladas, alimentam o banco de dados do hotel. Recentemente, alguns funcionários passaram a anotar estas respostas em alguns tablets. Segundo Castro (2011), “o tablet, usado para isto, é apenas um bloco de papel digital, que não faz muita diferença para quem está utilizando. No entanto, contribui bastante para a imagem de modernidade que faz parte do nosso posicionamento."

Finalmente, um último cuidado em relação à questão auditiva é o fato de todos os seguranças, funcionários de banquetes e equipe de governança usarem aparelhos de comunicação com fones de ouvido e microfones. O objetivo é evitar que os hóspedes ouçam a comunicação feita entre os funcionários, diminuindo também o ruído feito por estes aparelhos. Também neste caso, o equipamento ajuda a sedimentar a imagem de modernidade. 


\subsubsection{Resumo das Ações Sensoriais}

Quadro 3 - Hilton - Resumo das ações sensoriais

\begin{tabular}{|l|l|l|l|l|l|}
\hline \multicolumn{1}{|c|}{ Pontos de contato } & Visão & Olfato & Tato & Paladar & Audição \\
\hline Apartamentos & & & & & \\
\hline Áreas comuns & & & & & \\
\hline Bares e restaurantes & & & & & \\
\hline Centro de convenções & & & & & \\
\hline Áreas de lazer / esporte & & & & & \\
\hline Pessoas & & & & & \\
\hline Comunicação & & & & & \\
\hline
\end{tabular}

Fonte: elaborado pelo autor

Analisando de maneira simples o quadro acima, nota-se que o Hilton é o hotel que menos explora as ações sensoriais como ferramenta de marketing, em comparação com os outros hotéis analisados.

A análise deste hotel é similar à que foi feita no hotel Hyatt, ou seja, o Hilton também desenvolve algumas ações dentro de uma postura pró-ativa, ao mesmo tempo em que age seguindo alguns padrões em outras. Evidentemente que isto não é incoerente, pois se existe um padrão mínimo esperado pelo mercado para um determinado tipo de serviço, é coerente que se busque pelo menos seguir este padrão.

No entanto, como visto em LEVITT (1985), cada vez mais a disputa de mercado se dá não nos produtos e serviços básicos e esperados, mas sim nos produtos e serviços aumentados, que é o que efetivamente gera a diferenciação.

Por isso, se por um lado, não existe nenhum erro ou incoerência em se desenvolver algumas ações apenas para seguir os padrões mínimos do setor, também é verdade que balizar as ações desenvolvidas apenas por estes padrões é perder a oportunidade de criar elementos que efetivamente diferenciem os produtos e serviços da empresa. 
Vale lembrar que o Hilton explora a palavra "experiência" repetidas vezes em sua comunicação, como visto em algumas páginas do seu site.

Na questão visual, claramente o destaque é para o restaurante Canvas, que pode até mesmo ser classificado como restaurante temático. Como ele se posiciona como um "restaurantegaleria de arte", evidentemente que a questão visual é explorada intensamente. De todas as ações desenvolvidas pelo Hilton, é a que parece mais claramente posicionada em cima de um conceito. Isto é visível na roupa e na performance dos funcionários, no design dos cardápios e pratos, e até mesmo na tela em que os clientes podem deixar sua marca.

A ideia de ligar o hotel ao universo artístico abre um leque de oportunidades para que as experiências visuais sejam mais exploradas. No entanto, esta preocupação fica evidente apenas na decoração de algumas áreas comuns, com destaque para o lobby e, como já demonstrado, no restaurante Canvas.

A questão do paladar também não é muito explorada. A única ação que pode ser colocada como pró-ativa em termos de marketing experiencial é o desenvolvimento dos brindes de chocolate e de pimenta, que podem realmente causar uma memória sensorial. Mas, também aqui vemos que existem várias outras opções que poderiam ser desenvolvidas seguindo os conceitos do hotel.

Com relação ao olfato, pode ser dito que o Hilton não tem nenhuma ação que explore esse sentido. O único item é a recomendação para os funcionários que, como já mostramos, faz parte de qualquer manual de hotelaria de luxo.

Vale repetir aqui a afirmação feita anteriormente, mostrando que o sentido do olfato é muito mal explorado pelo Hilton que, com isso, perde a oportunidade de explorar com mais consistência um dos sentidos mais sensíveis do ser humano.

O sentido do tato também é muito pouco explorado, seguindo-se as recomendações tradicionais com relação à cama e enxoval. A exceção neste ponto é a preocupação com as janelas no banheiro dos quartos, que dão uma sensação de transparência e iluminação natural, diminuindo a sensação claustrofóbica que alguns hóspedes tem. 
Além disso, também pode ser destacada a ideia de se trabalhar com mais de um elemento no piso dos quartos, variando de madeira para carpete, no sentido de causar uma sensação diferente que estimule a percepção de área de trabalho e área de descanso. Essas duas ações se encaixam como ações experienciais.

Por fim, o sentido da audição também não é explorado como ferramenta de marketing. $\mathrm{O}$ script dos funcionários que recomenda que se diga "o que mais posso fazer por você?" ainda não virou uma marca, como vimos no Hyatt. As outras ações desenvolvidas seguem o caminho de padrões estabelecidos.

Em resumo, podemos afirmar que o uso das experiências sensoriais como ferramenta de marketing pelo Hilton ainda está numa fase inicial, em que pese algumas ações que claramente podem ser consideradas como tal.

Isto parece que pode ser alterado pois, a base para estas mudanças já existe em termos de cultura corporativa. É o que mostrou Castro quando citou que o "intangível é mais lucrativo que o tangível", além das suas ideias sobre "as pequenas coisas baratas" e "customização padronizada".

Isto significa certa pré-disposição para novas ideias, o que claramente ajuda no desenvolvimento de novas ações de marketing. Quando se observa a grande preocupação do hotel com a avaliação que o hóspede faz no momento do check-out, entende-se que isso pode ser o elemento que influencie o hotel a desenvolver novas ações sensoriais. 


\subsection{Descrição do caso L’Hotel Porto Bay}

\subsubsection{Fontes de Informações consultadas}

\section{Páginas da internet}

PORTO BAY. 2011. Disponível em < http://www.portobay.com > Primeiro acesso em $06 / 10 / 2011$.

TRIP ADVISOR. Disponível em: < www.tripadvisor.com > Primeiro acesso em 09/10/2011.

\section{Entrevistas}

Entrevista com o Sr. Claudio Santos (SANTOS, 2011), Gerente Geral dos Hotéis Porto Bay no Brasil, realizada no dia 08/11/2011, na sede do L'Hotel Porto Bay.

O Sr. Claudio Santos tem graduação e pós-graduação em administração. Passou boa parte de sua vida profissional trabalhando em consultoria financeira. No grupo Porto Bay, era o diretor para a área de desenvolvimento de negócios até vir para o Brasil, há 2 anos, para gerenciar e desenvolver as operações do grupo aqui.

\section{Observações}

Observações presenciais realizadas no L'Hotel Porto Bay nos dias 08/11/2011 e 19/11/2011.

\subsubsection{Informações gerais sobre o hotel}

O grupo Porto Bay foi fundado em 1988, na Ilha da Madeira, em Portugal, por um grupo de investidores privados - ou seja, é um grupo bastante novo em comparação com os outros dois grupos analisados nesta pesquisa. O primeiro hotel do grupo foi o Suite Hotel Eden Mar, na cidade de Funchal, inaugurado em 1988, com um conceito de apartamentos grandes, equipados com quitinetes. 
Em 1994, também na cidade de Funchal, o grupo inaugurou o The Cliff Bay, posicionado na categoria de 5 estrelas. No ano 2000 o grupo inaugurou o Porto Santa Maria, também em Funchal, num projeto que fez uma fusão entre um hotel de cidade e um resort.

Em dezembro de 2003, na cidade de Funchal, foi aberto o resort Vila Porto Mare, que integrou o Hotel Eden Mar, o Hotel Porto Mare e o The Residence. Neste projeto, há um espaço comum onde serviços e instalações são usados pelos clientes dos três hotéis.

Em janeiro de 2007 o grupo deu seu primeiro passo para a internacionalização, comprando o Hotel Porto Bay Rio Internacional, na praia de Copacabana, no Rio de Janeiro. Esta aquisição foi feita em conjunto com a empresa portuguesa Logoplaste, iniciando a participação desta empresa em projetos da Porto Bay. Em junho do mesmo ano o grupo comprou a pousada Porto Bay Glenzhaus, na cidade de Búzios, com o objetivo de funcionar como complemento ao hotel do Rio de Janeiro.

Em 2008 o grupo inaugurou em Algarve o Porto Bay Falésia, que foi o primeiro hotel do grupo no continente português. Em 2009, o grupo comprou o L'Hotel, que passou a se chamar L’Hotel Porto Bay São Paulo.

A Porto Bay tinha, em novembro/2011, um total de 9 hotéis, com 1.318 quartos e cerca de 2.600 camas, nos segmentos de 4 e 5 estrelas, conforme podemos ver na tabela 14 .

Tabela 14 - Hotéis do grupo Porto Bay

\begin{tabular}{|c|c|c|}
\hline Hotel & Localização & Aptos. \\
\hline The Cliff Bay & Ilha da Madeira - Portugal & 201 \\
\hline Porto Santa Maria & Ilha da Madeira - Portugal & 146 \\
\hline Porto Mare & Ilha da Madeira - Portugal & 200 \\
\hline Eden Mar & Ilha da Madeira - Portugal & 146 \\
\hline The Residence & Ilha da Madeira - Portugal & 99 \\
\hline Porto Bay Falésia & Algarve - Portugal & 310 \\
\hline Porto Bay Rio Internacional & Rio de Janeiro - Brasil & 117 \\
\hline Porto Bay Glenzhaus & Búzios - Brasil & 17 \\
\hline L’Hotel Porto Bay & São Paulo - Brasil & 82 \\
\hline Total & & 1.318 \\
\hline
\end{tabular}

Fonte: Adaptado de Porto Bay (2011) 
Segundo SANTOS (2011), os planos para expansão no Brasil incluem projetos no Rio de Janeiro, São Paulo e Belo Horizonte.

\subsubsection{Hotel Pesquisado}

O L'Hotel Porto Bay São Paulo foi adquirido pelo grupo Porto Bay em 2009, e localiza-se na Alameda Campinas, 266, São Paulo. De acordo com o site do hotel (PORTO BAY, 2011), o hotel oferece a seguinte estrutura:

\section{Acomodações}

O L'Hotel Porto Bay São Paulo tem 82 quartos:

Seus apartamentos e suítes têm as seguintes comodidades:

- Controle de temperatura

- Roupão e chinelos

- $\quad$ TV de LCD

- TV a cabo

- Cofre digital

- Internet banda larga

- Secador de cabelo

- Ferro de passar roupa

- Refrigerador

- Produtos L'Occitane

- Travesseiros e edredom de pena de ganso

- Roupa de cama $100 \%$ algodão

- Banheiro de mármore

- Rádio com alarme

\section{Serviços ao Hóspede}

Os principais serviços oferecidos pelo hotel aos seus hóspedes são:

- Concierge 24 horas 
- Serviço de quarto 24 horas

- Business Center

- 1 restaurante (Cozinha italiana)

- Piano Bar

- Spa

- Fitness Center

- Serviço de Secretaria

- Transfer para aeroportos

- Estacionamento

- Personal shopper

- Piscina climatizada

- Centro de Convenções para 300 pessoas

- Equipamentos de áudio e vídeo

- Lavanderia

- Serviços de valet

\subsubsection{Questões gerais de Marketing}

Como demonstrado anteriormente, o grupo Porto Bay opera no Brasil com três unidades: um hotel no Rio de Janeiro, uma pousada em Búzios, e o L’Hotel, em São Paulo.

No L'Hotel, a tarifa média é de R\$ 498,00, e a taxa de ocupação em 2011 foi de $72 \%$. Segundo SANTOS (2011), este é um índice alto para uma cidade como São Paulo, pois para se chegar a esta média, significa que durante a semana o hotel opera com taxas de ocupação acima de $85 \%$, ou seja, perto de seu limite máximo. No fim de semana o hotel tem cerca de $60 \%$ de taxa de ocupação.

O L'Hotel inaugurou seu novo centro de convenções no final de outubro/2011, ampliando suas instalações com a aquisição de um prédio que fica ao lado do hotel.

O perfil básico dos hóspedes é de executivos, que representam $85 \%$ da ocupação. Um dado interessante a respeito disto é que a ocupação no domingo subiu consideravelmente, e isto se deve às más condições da cidade. SANTOS (2011) diz que: 
“os voos atrasam muito e o trânsito é horrivel. Por isso, essa dificuldade de mobilidade na cidade, que tem aumentado, tem feito com que os hotéis tenham nos domingos um dos dias de melhor ocupação, pois os executivos preferem chegar no domingo à noite para começarem a trabalhar na $2^{a}$ feira pela manhã, sem enfrentar o stress por atrasos e congestionamentos".

Cerca de $50 \%$ dos hóspedes são brasileiros, seguidos por americanos, alemães, japoneses e portugueses. Dentro deste perfil, há certo predomínio de executivos de empresas multinacionais, que representam $80 \%$ dos hóspedes, com pequena ênfase para executivos de empresas dos setores farmacêutico, automobilístico e financeiro.

A análise que Santos faz da hotelaria de São Paulo, apesar de positiva, tem uma postura crítica, especialmente em relação aos hotéis de luxo. Santos afirma que:

"Mais da metade da hotelaria de SP é constituída por flats, que oferecem padrões de serviços fracos e custos menores. Imagino que as pessoas devem estar satisfeitas com isso, porque continuam a usar. É um trade off-todo mundo paga menos, recebe menos e fica todo mundo feliz com isso, a não ser eventualmente quem investiu no flat. Nos hotéis, o nível de serviço em São Paulo é bom - seguramente é o melhor do Brasil. Isto porque há uma cultura de serviços em SP. Comparando com cidades europeias, a média de serviços em SP se equipara com cidades na Europa e EUA. Mas na hotelaria de luxo não se consegue esse mérito. A hotelaria de luxo em São Paulo ainda é mais baseada em comunicação e marketing do que em serviço. Os mesmos U\$ 800.00 que se paga aqui num hotel de luxo, paga-se também no Ritz Carlton de New York - e existe uma enorme diferença no padrão de serviços. Em São Paulo não existe nenhum hotel que se compare ao Ritz ou ao Four Seasons, embora haja produtos mais caros que esses. Por isso, fico surpreso em não ver estas marcas operando aqui. Acho que os clientes daqui são exigentes, principalmente os de certa classe econômica, e a concorrência é fraca, ou seja, é uma boa concorrência no contexto Brasil, mas é fraca dentro do contexto luxo. Portanto, acho que há espaço no mercado para marcas como essas aqui em São Paulo." (SANTOS, 2011) 
Como visto, a postura crítica é exatamente em relação aos serviços prestados, seja no mercado de flats, seja na hotelaria de luxo. Isto mostra uma preocupação bastante grande que o executivo tem com a oferta de bons serviços, e esta visão vai aparecer, como veremos, em algumas das ações desenvolvidas pelo L'Hotel.

Independente disto, nesta afirmação mais uma vez existe a já citada confusão de conceitos entre marketing e comunicação, pois nos parece contraditório afirmar que a hotelaria de luxo é baseada em marketing e comunicação, mas não tem os melhores serviços. Claramente, o termo marketing desta afirmação está sendo usado como sinônimo de comunicação, e não no seu sentido correto e amplo.

Tendo por base esta análise do mercado de hotelaria de luxo, o L'Hotel entende que seus principais concorrentes são os hotéis Renaissance, Intercontinental e Tivoli, pois não apenas estão na mesma área de influência, como atuam no mesmo segmento e com tarifas próximas. Além destes, no mercado de luxo o L’Hotel concorre também com Emiliano, Fasano e Unique, que tem tarifas mais altas (cerca de R\$1.000,00), e tem um foco maior em turismo de lazer.

De acordo com SANTOS (2011):

"o primeiro diferencial em relação ao Renaissance, Intercontinental e Tivoli é, obviamente, o tamanho. O tamanho faz toda a diferença na experiência que você consegue ter num hotel. Como o L'Hotel é bem menor, isso nos permite oferecer um padrão de serviço diferente, fundamentalmente através de uma maior proximidade com clientes. Temos uma proximidade com nossos clientes bastante superior aquela que hotéis maiores conseguem ter. Esse diferencial é determinante para a fidelização de clientes. Eu não chamo isso de personalização - não acho que cheguemos a isso, mas permite um nível de proximidade que só se consegue num hotel deste tamanho. Conhecemos nossos clientes pelo nome, e pesquisamos na internet os clientes que vem pela primeira vez, para tentar recebê-los com uma atitude de quem já sabe quem eles são." 
Outro fator que diferencia o L'Hotel é o constante reinvestimento nos hotéis, que chega a ser cerca de duas vezes maior que a média da concorrência. O objetivo é manter um padrão superior em relação à concorrência, em termos de "hardware", ou seja, em termos de equipamentos, mobiliário e enxoval. Isto porque o hardware que tem alto grau de utilização tende a ficar com aparência de usado, desgastado. Segundo SANTOS (2011) "este é outro de nossos grandes diferenciais - por isso reinvestimos no hotel, mesmo sacrificando um pouco nossa rentabilidade, mas com resultados comerciais frente à concorrência que compensam."

A satisfação dos clientes tem apresentado resultados muito bons, como vimos anteriormente, nos dados do Trip Advisor. Os objetivos do L'Hotel são bastante claros em relação a esta avaliação: a meta é atingir o $1^{\circ}$ lugar, tanto em São Paulo como também no Rio de Janeiro, no primeiro semestre de 2012.

Para isso, o hotel tem um programa interno de satisfação de clientes (que é para todo o grupo). Neste programa, semanalmente uma empresa de pesquisa independente vai até o hotel no horário do café da manhã e pesquisa a satisfação dos hóspedes. Esta pesquisa gera um resultado superior àquele conseguido com o preenchimento de formulários que são deixados nos quartos. Com este sistema, o hotel consegue cobrir cerca de $75 \%$ dos hóspedes daquele dia.

Este é um procedimento adotado e padronizado para todos os hotéis do grupo. Pelo sistema, as pesquisas devem ser feitas até as 10:00h, e os resultados devem estar disponíveis para os gerentes até as 12:00h do mesmo dia.

Com os resultados em mãos, os gerentes podem tentar resolver alguns dos problemas relatados enquanto o hóspede ainda está no hotel. Segundo Santos (2011),

"isto faz com que a gente consiga ter um alto índice de satisfação, não apenas com o serviço em si, mas principalmente com a solução dos problemas apontados. Se o hospede já tiver saído, ou se não tivermos condições de resolver o problema de imediato, entramos em contato com ele e explicamos as ações que serão tomadas. " 
Santos afirma que este método faz aumentar a fidelização dos clientes, já que $30 \%$ dos hóspedes são clientes ativos, ou seja, voltam a se hospedar. "Este processo de pesquisar e resolver o problema contribui para esta fidelização, porque mostra ao hóspede que seu feedback produz resultado e não serve apenas para alguém ouvir e guardar o resultado embaixo da mesa". (SANTOS, 2011)

Este processo parece bastante interessante, pois indica uma atitude mais pró-ativa do hotel em relação à busca pela solução dos problemas indicados pelos hóspedes. Evidentemente que, quando o hóspede ainda está hospedado e faz uma reclamação qualquer, espera que a mesma seja solucionada. Esta expectativa decorre basicamente porque este tipo de reclamação é feita diretamente a algum funcionário do hotel e, por isso, espera-se uma solução de imediato.

No entanto, o procedimento de pesquisa adotado pelo L'Hotel sugere algo que acaba por surpreender positivamente o hóspede, pois a expectativa quando se responde uma pesquisa não é a de que o problema vai ser resolvido de imediato, nem que se obterá um feedback no mesmo dia. Ou seja, parece que a atitude de responder às reclamações dos hóspedes de fato indica que o hotel tem a preocupação em melhor servi-lo.

Em relação às ações de marketing desenvolvidas, SANTOS (2011) é enfático:

“O marketing não é nosso carro chefe. Ao contrário de nossos concorrentes, principalmente Unique, Emiliano e Fasano, que apostam muito no marketing e querem sempre estar associados a nomes e fenômenos de moda que os ajudam a obter o posicionamento que querem, a nossa prática não é essa. Nosso marketing é muito limitado, e bastante baseado em marketing de relacionamento direto com o cliente."

Para isso, o grupo tem um programa de fidelidade com dois níveis, dependendo do número de estadias que os hóspedes tem. O programa tem cerca de 120 mil nomes, e é gerenciado diretamente pela matriz da empresa, em Portugal. Para esse grupo de hóspedes, as ações mais constantes são a entrega gratuita de uma revista corporativa, a comunicação de condições diferenciadas em termos de tarifas, e eventuais up grades nas estadias. 
Além disso, o L'Hotel desenvolve algumas ações durante o ano, normalmente ligadas à arte e música em São Paulo, e um pouco mais focadas em esportes no hotel do Rio de Janeiro.

Segundo SANTOS (2011), a ideia é desenvolver ações que "tenham a ver com a cidade, ou seja, queremos ser vistos como o hotel dentro da cidade, e não como um hotel estrangeiro na cidade. Por isso, procuramos interagir um pouco mais com a cidade, em que pese o fato de, sendo um hotel pequeno, não existir muita margem para patrocínio e estadia”.

O L'Hotel tem uma postura mais low profile, e assume isso como forma de se diferenciar da concorrência. SANTOS (2011) também enfatiza esta questão:

"Nossa forma de trabalhar sempre vai privilegiar o serviço e não a comunicação. No nosso DNA não está a preocupação em ser top mind. Em SP não existia o hotel bom e low profile, o hotel que não tentava aparecer na mídia. Temos uma boa porcentagem de clientes que privilegiam o intimismo. Não temos grandes cantores mundiais se hospedando aqui, mas temos hóspedes mundialmente famosos em suas áreas de atuação, e que também tem estilo mais low profile. Esses hóspedes não querem ir para nossos concorrentes porque sabem que ali podem ter um hotel fantástico, excelente, mas sabem que são hotéis que existem porque as pessoas querem ser vistas lá, e o L'Hotel existe também porque as pessoas não querem ser vistas aqui. É esse low profile que cultivamos, um intimismo maior."

Apesar disto, em São Paulo, por exemplo, o L’Hotel é um dos patrocinadores da São Paulo Fashion Week, e também tem uma ligação com a Fórmula 1.

Existe certa contradição no discurso de Santos pois, se por um lado ele afirma que o L'Hotel não pretender estar ligados a nomes e fenômenos de moda para aparecer, por outro lado afirma que é um dos patrocinadores da São Paulo Fashion Week. Esta pequena contradição pode ser entendida como a tentativa do hotel em estar patrocinando o evento, mas não associa seu nome às celebridades que dele participam. O fato não deixa de ser contraditório, em que pese a contradição ser pequena, e ficar restrita a um único evento. 
Outro ponto que merece destaque é que, também no L'Hotel existe a confusão entre ações de marketing e comunicação. Isto fica claro quando se vê que todas as respostas a respeito de ações de marketing convergem para ações eminentemente de comunicação.

\subsubsection{Visão sobre Marketing Experiencial}

A visão do L'Hotel sobre Marketing Experiencial é bastante interessante. Segundo SANTOS (2011):

“Eu já li alguma coisa sobre isso, mas não sei exatamente o que é. O conceito me parece interessante, mas muitas vezes as pessoas falam que fazem marketing experiencial, mas não praticam. Entendo que marketing experiencial é menos uma questão de atitude nova e muito mais uma questão de dar um nome novo a um conjunto de atitudes que já existiam, e que ninguém conseguia exatamente identificar como sendo marketing. Por isso, tenho dúvidas em dizer que fazemos marketing experiencial, porque toda área de serviços é eminentemente experiencial. As pessoas compram um serviço e neste processo vai se vivenciar uma experiência que vai fazer com que as pessoas gostem mais ou não do processo de compra, independentemente do serviço ser o mesmo."

Esta é uma opinião extremamente interessante, e que chama bastante a atenção pois, de alguma forma, sintetiza boa parte do que foi discutido na revisão teórica quando afirmado que o conceito de Marketing Experiencial é um desenvolvimento das técnicas de marketing, não podendo ser visto como algo novo, que contradiga os conceitos clássicos de marketing.

No L'Hotel existe uma grande preocupação em incentivar uma grande proximidade entre clientes e funcionários, buscando maior interação.

De acordo com SANTOS (2011): 
“A hotelaria é muito hermética - as pessoas oferecem um nível de serviços que formalmente é bem feito, mas sem uma atenção muito grande na questão relacional. Você pode servir a mesma coisa de uma forma diferente. Nós procuramos aumentar ao máximo os pontos de contato, estimulando as pessoas para esses pontos de contato, incentivando uma interação menos formal. Por exemplo, a maior parte dos funcionários dos restaurantes e da recepção trata o cliente pelo nome, e sabem realmente quem são estas pessoas."

A afirmação de Santos pode ser comprovada pela ilustração 65. O site do hotel tem uma área específica para a equipe, contendo nome, cargo e foto. Dos hotéis pesquisados, é o único que coloca este tipo de informação no seu site.

Esta atitude é coerente com a proposta do L'Hotel em criar maior proximidade entre funcionários e hóspedes, pois já dá a possibilidade do cliente tomar um primeiro contato, ainda que por meio virtual, da equipe que o atenderá.

Ilustração 65: Site L'Hotel

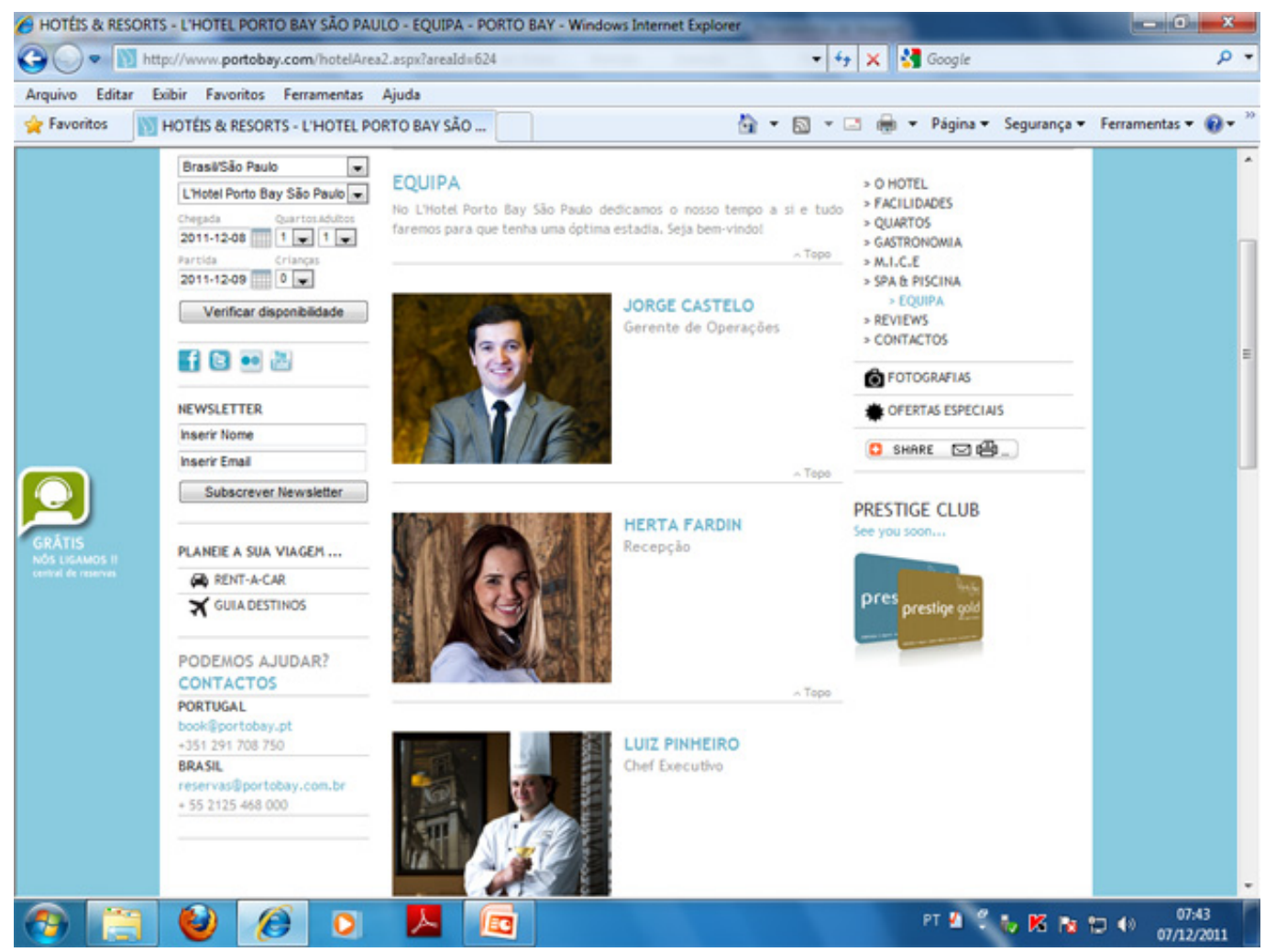

Fonte: PORTO BAY, 2011 
Aqui também existe uma convergência entre o que é praticado pelo L'Hotel e alguns dos conceitos que desenvolvidos na fundamentação teórica. Neste caso, é explícita a preocupação com os pontos de contato, entendendo que eles são fundamentais para a oferta de um serviço diferenciado no sentido de gerar uma percepção positiva por parte dos clientes. SANTOS (2011) completa dizendo que:

"Nossa visão do marketing experiencial tem a ver com isso: procurar definir um conceito de serviço que as pessoas gostem, que dê prazer às pessoas, que façam com que elas tenham memórias boas, que falem aos amigos sobre essas memórias boas que tiveram aqui."

Retomando um pouco o que foi colocado anteriormente a respeito dos pontos que diferenciam o L’Hotel em relação ao perfil dos seus clientes, é interessante a síntese feita por Santos. Segundo ele:

"Os itens mais importantes para o hóspede variam de hotel para hotel. Aqui em São Paulo o hóspede busca um check in e um check out rápidos. Esta é uma das coisas que mais deixa boa memória nos clientes. Além disso, dentro do apartamento, é fundamental a cama, e os americanos descobriram isso há algum tempo. A cama é o maior ponto de contato entre o hotel e o hóspede. Uma boa cama quer dizer, um bom colchão, bons lençóis. Depois, temos as toalhas, que também são fundamentais - nós sentimos isso quando demoramos muito para trocar as toalhas por outras mais novas, porque as pessoas reclamam. Outro ponto importante são os amenities - quanto melhor e mais caros, mais as pessoas levam. Nossas amenities são da L'Occitane e, por isso, nossos hóspedes levam tudo. Isso significa não apenas que o preço de cada unidade é mais alto, pela qualidade da marca, como também o volume consumido é maior." (SANTOS, 2011)

A questão das amenities é bastante interessante. O L'Hotel oferece produtos da L'Occitane, uma empresa francesa, presente em mais de 80 países, com cerca de 1.900 lojas. É uma marca reconhecida mundialmente como uma das melhores no segmento de higiene pessoal, ou seja, o conceito de qualidade está totalmente ligado à sua marca. 
Como afirmou Santos, o consumo per capita destes produtos é maior, não apenas porque os hóspedes usam os produtos com mais intensidade e quantidade, como também levam de brinde quando voltam para suas cidades. Esses produtos estão diretamente relacionados com aspectos sensoriais, em especial, o olfato e o tato.

Parece claro, então, concluir que, se o consumo per capita é maior, quando comparado com amenities de outras marcas, é porque estes produtos são melhores percebidos pelos hóspedes. Consequentemente, uma parcela do conceito de qualidade que a marca L'Occitane tem é transferida para o L'Hotel.

Indo além, deve-se notar que alguns dos pontos que Santos coloca como sendo fundamentais para se agregar valor para os clientes, com exceção da rapidez do check in e check out, são diretamente ligados a questões sensoriais - colchão, lençóis, toalhas e amenities.

Isto reforça a ideia de que as experiências sensoriais sempre acontecem - o que varia é a forma como cada organização - no caso deste estudo, como cada hotel - gerencia estas questões.

\subsubsection{Ações Sensoriais}

\section{Visão}

Como visto, o L'Hotel tem um posicionamento low profile, discreto. Por isso, a exploração do sentido da visão pelo hotel busca seguir este caminho, ainda que, como afirma o próprio executivo do grupo, o conceito seja um pouco vago.

O estilo mais discreto pode ser percebido, em primeiro lugar, pelo próprio prédio do hotel que, como vemos na ilustração 66, tem um projeto arquitetônico bem diferente do Hilton e do Hyatt. Aqui, é um prédio tradicional, de linhas retas, com a parte de alvenaria pintada de bege, sem nada que possa ser caracterizado com ousado. Evidentemente, por ter apenas o prédio também é bem menor que os outros hotéis analisados, o que reforça a imagem de discrição. 


\section{Ilustração 66: Fachada do L'Hotel}

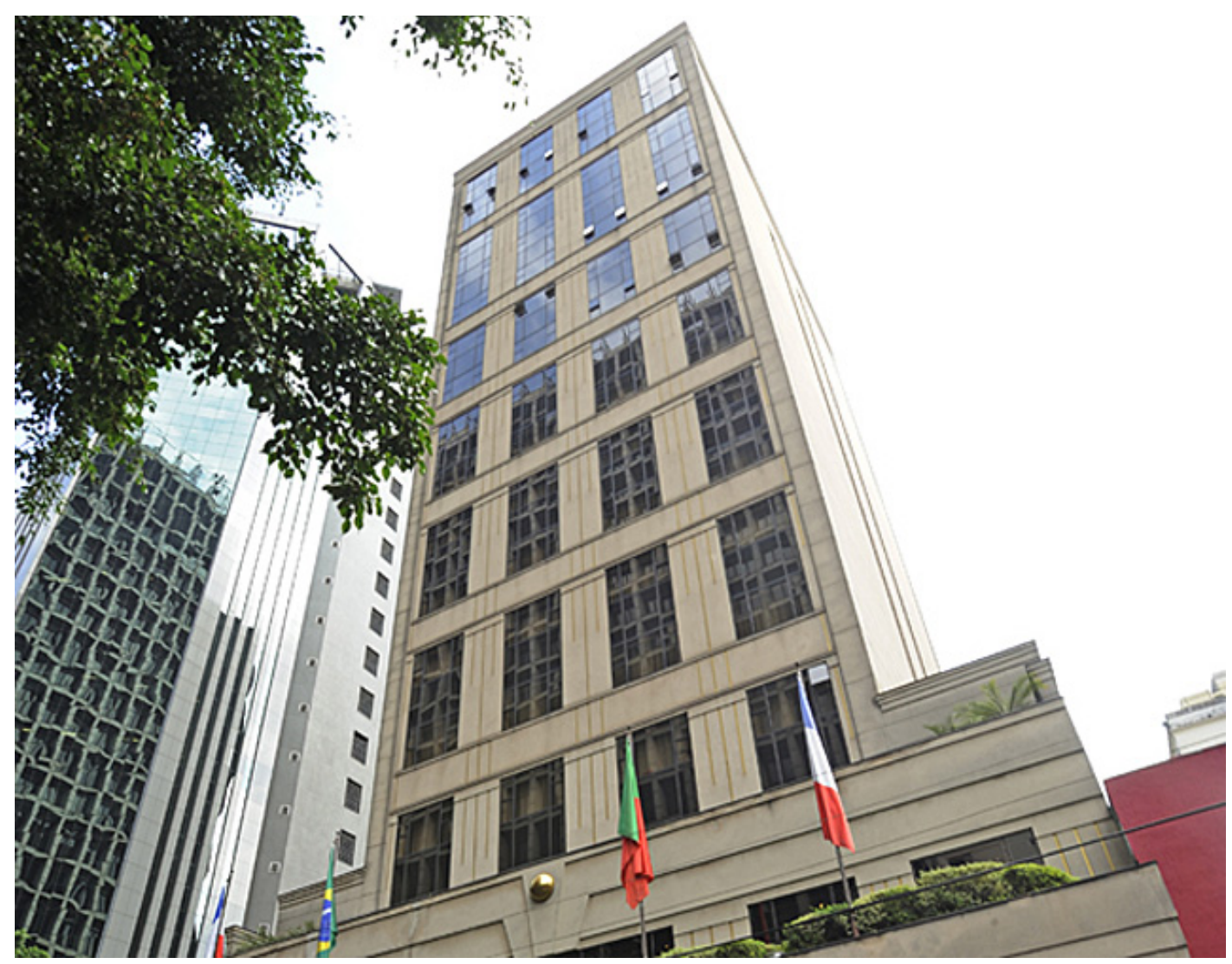

Fonte: L'HOTEL, 2011

Ainda na questão cromática, o que se procura, fundamentalmente, é buscar uma linha uniforme, apostando sempre em tons suaves. Segundo SANTOS (2011):

“dificilmente você vai encontrar algo amarelo, vermelho ou preto. Buscamos o denominador comum, ou seja, aquilo que não vai surpreender ninguém, mas vai fazer com que as pessoas se sintam identificadas com o ambiente. A cromia das áreas sociais e dos quartos é algo que você vai encontrar em todos os nossos hotéis, mostrando que existe ali um fio condutor."

Este conceito fica bastante claro quando examinadas as ilustrações seguintes. Nelas, pode ser visto que os quartos (67), o lounge (68), a recepção (69), o lobby (70) e o hall dos andares (71) tem não apenas um padrão cromático, como também uma grande harmonia visual em termos de objetos de decoração.

Os tons usados são sempre pastéis, suaves, e a decoração é clássica, bem de acordo com a questão do posicionamento low profile, e seguindo a linha da própria arquitetura do prédio. 
lustração 67: Quarto

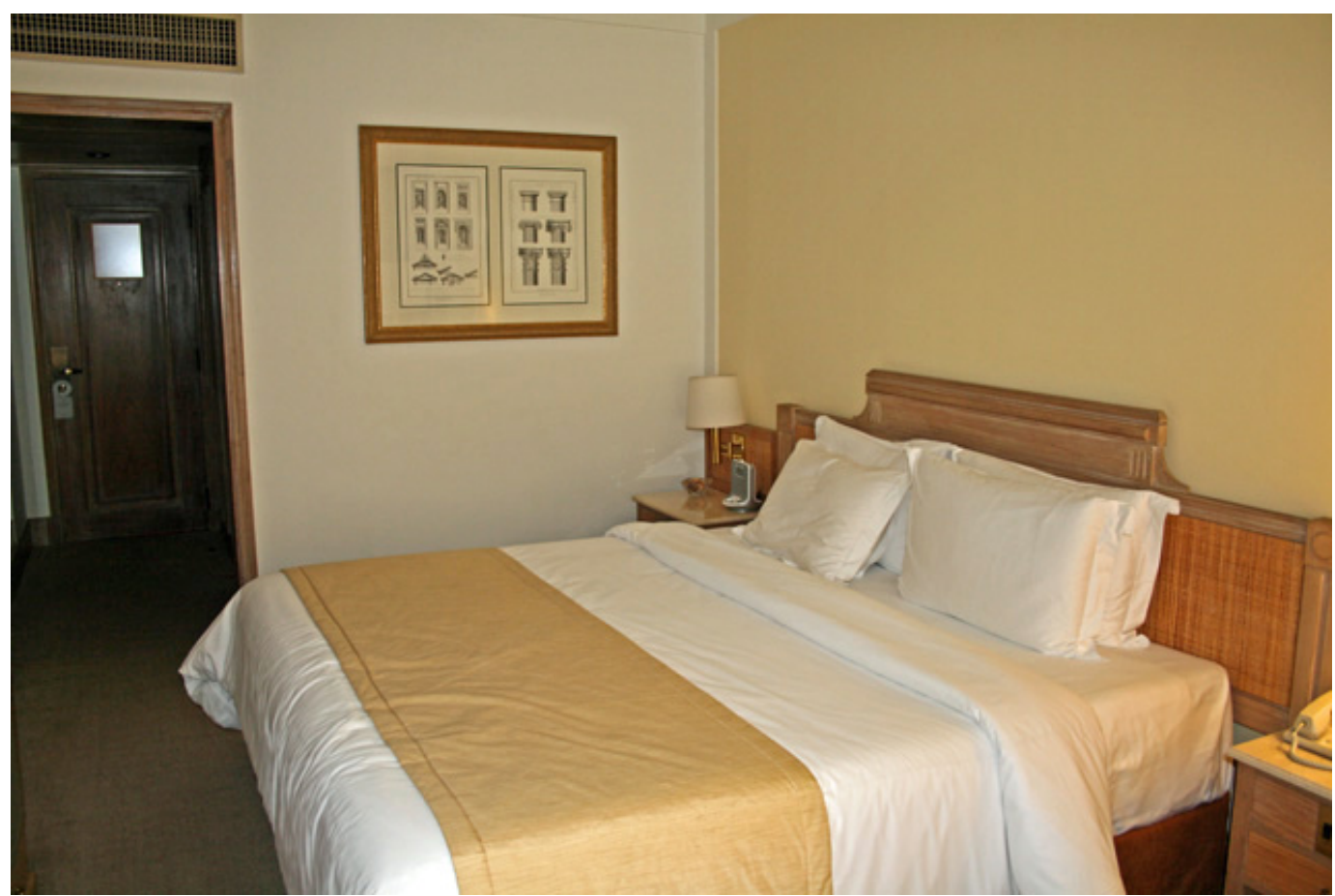

Fonte: foto tirada pelo autor, em visita realizada dia 19/11/2011

\section{Ilustração 68: Lounge}

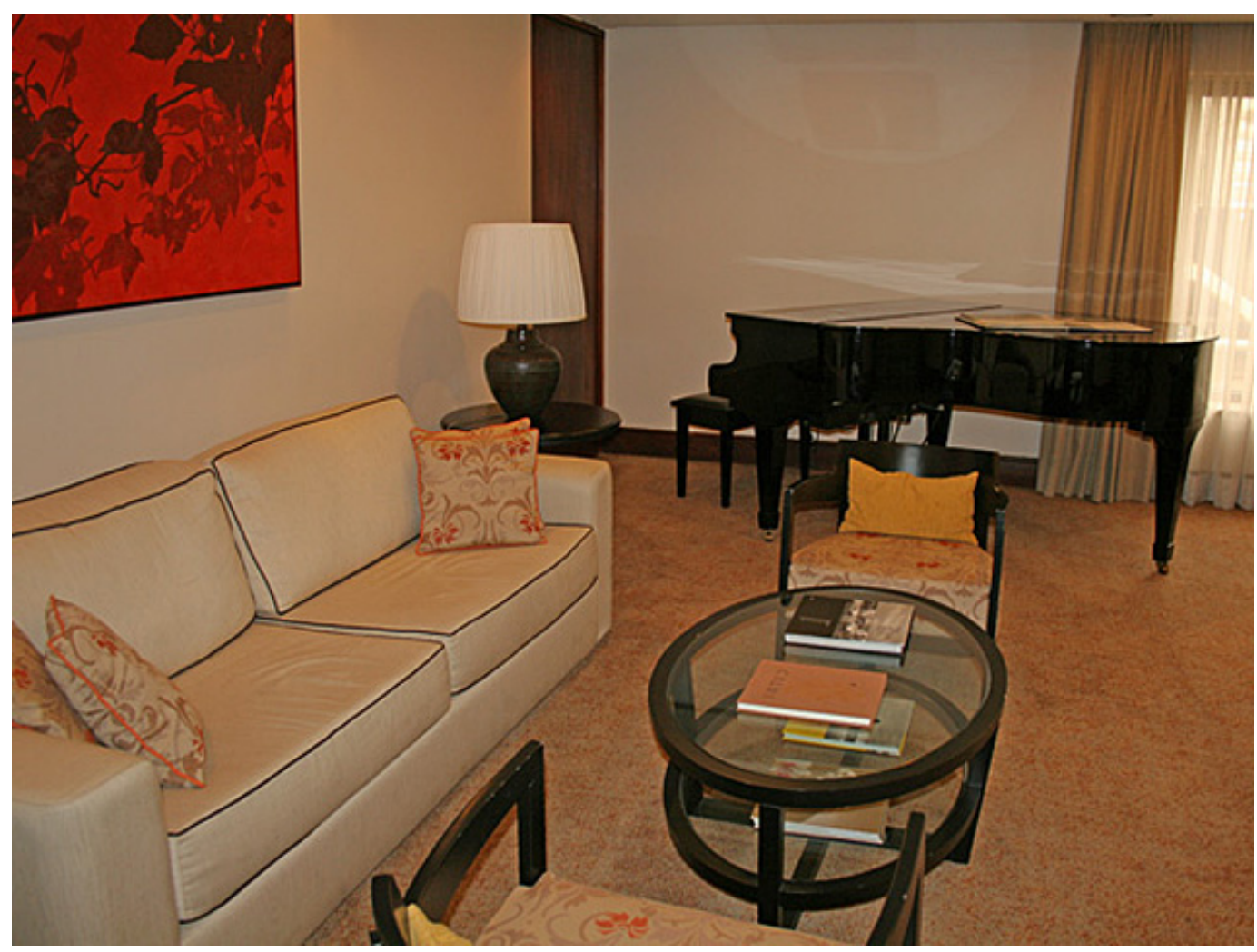

Fonte: foto tirada pelo autor, em visita realizada dia 19/11/2011 


\section{Ilustração 69: Recepção e concierge}

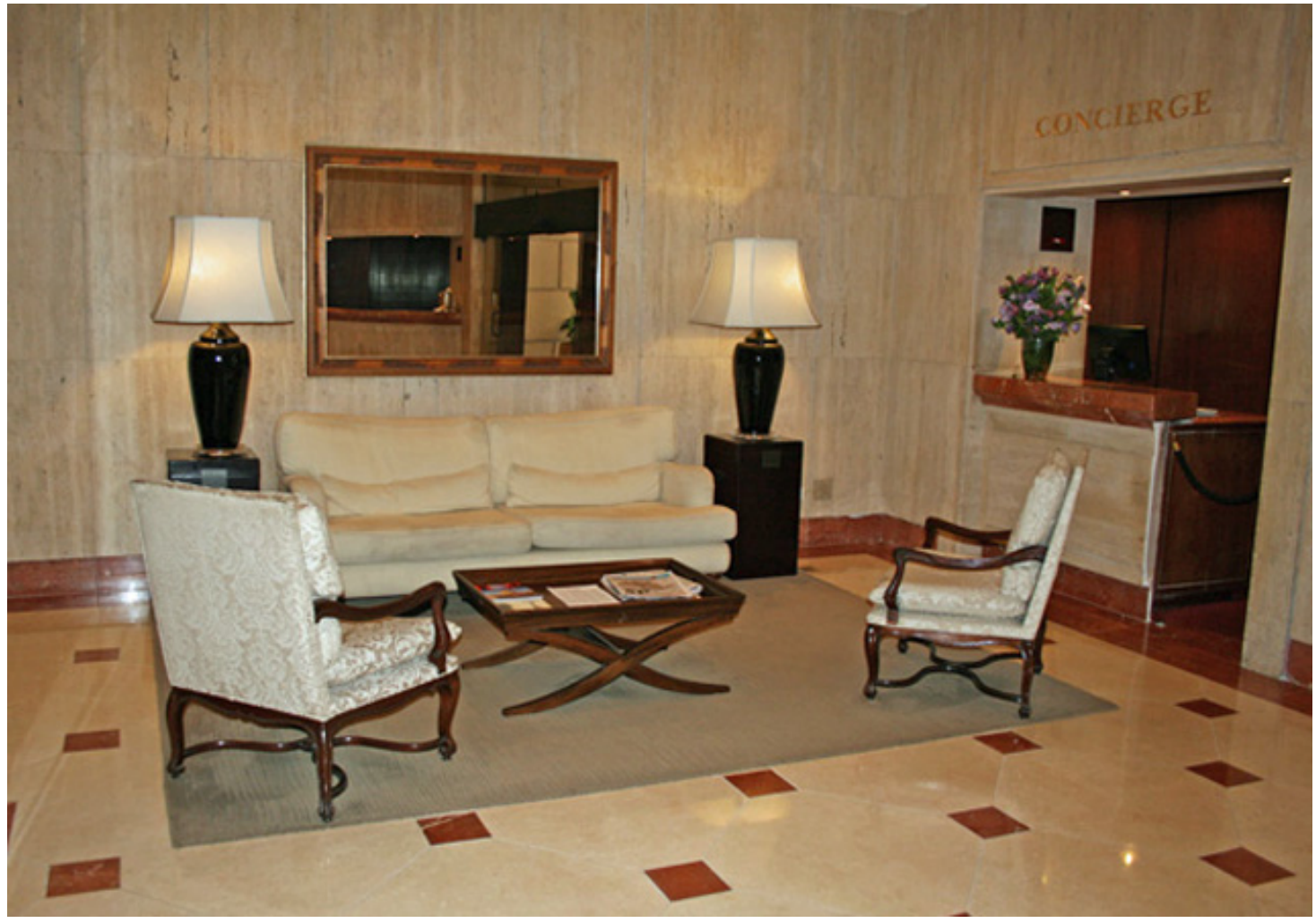

Fonte: foto tirada pelo autor, em visita realizada dia 19/11/2011

\section{Ilustração 70: Lobby}

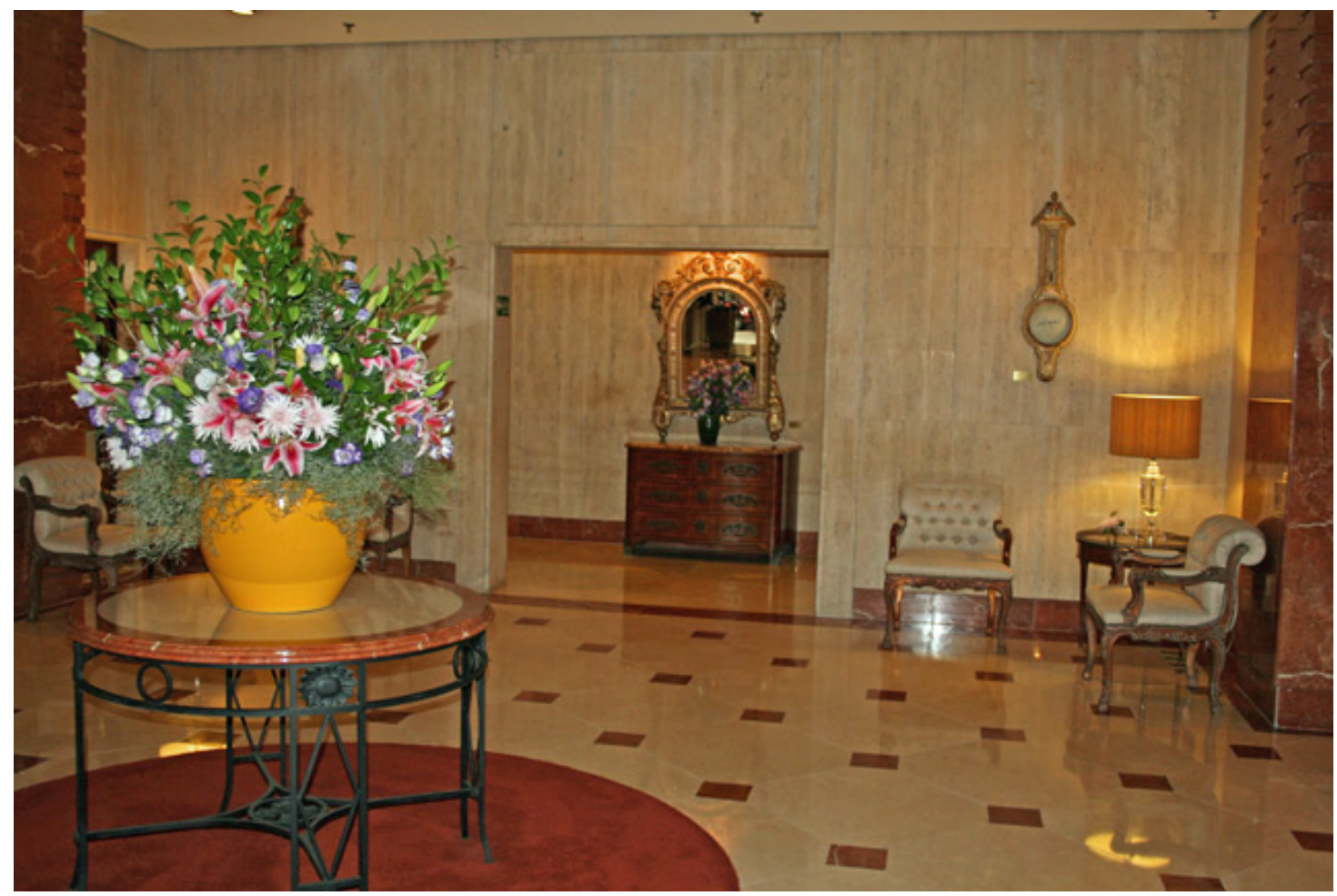

Fonte: foto tirada pelo autor, em visita realizada dia 19/11/2011 


\section{Ilustração 71: Hall dos andares}

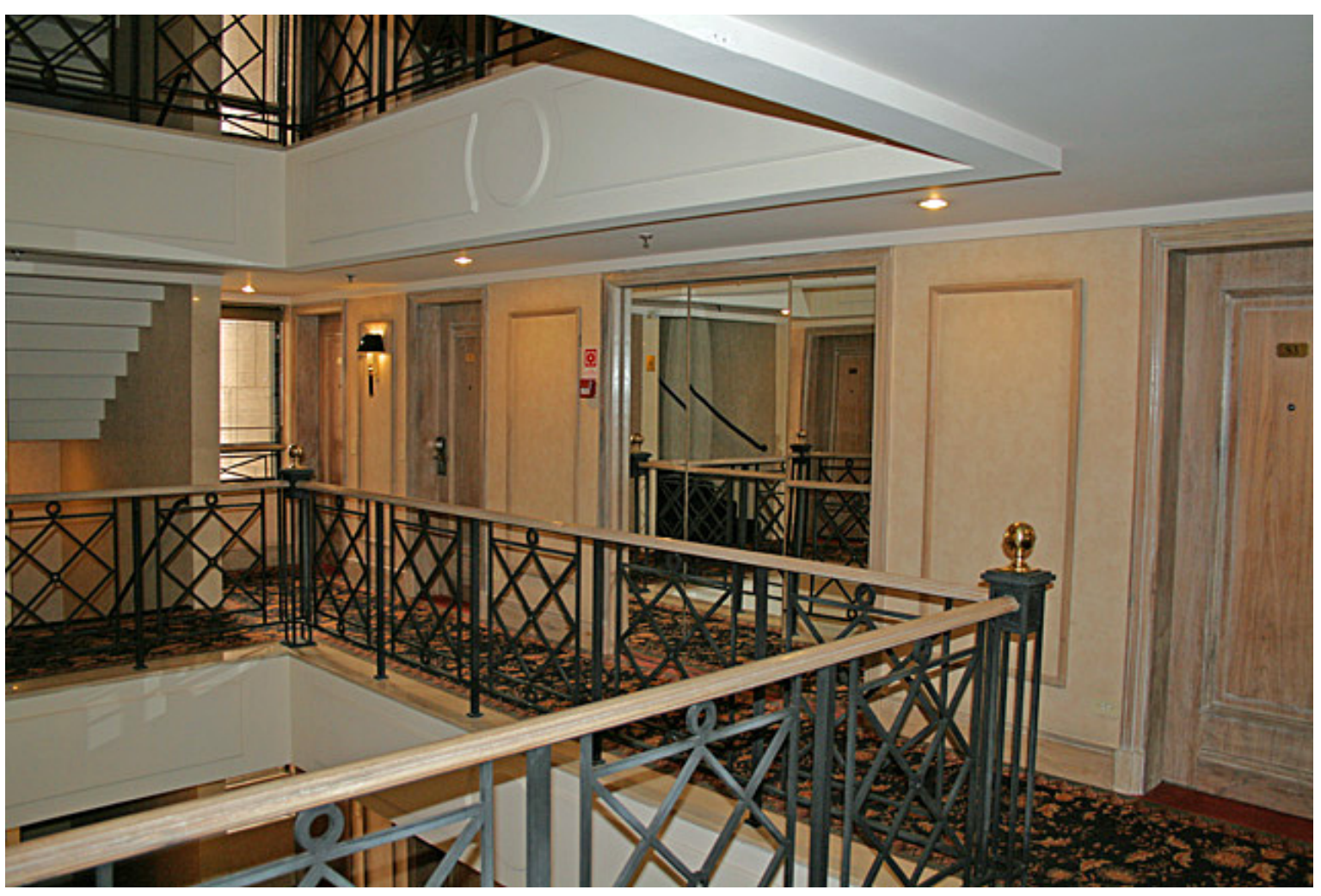

Fonte: foto tirada pelo autor, em visita realizada dia 19/11/2011

No aspecto visual, além das questões ligadas à decoração, existe também a vestimenta dos funcionários. As roupas são sóbrias e, na opinião de Santos, "um pouco old fashioned no seu formalismo".

Nas observações feitas, observa-se que o uso de roupas tradicionais para este tipo de hotel, com os homens das áreas de recepção trajando paletó e gravata, e as mulheres usando tailleur. As cores não variam muito, sendo normalmente azul-escuro, cinza ou preto. No L’Hotel também existem as recomendações tradicionais: mulheres sem maquiagem excessiva, sem unhas com cores fortes, e homens com cabelo curto, barba feita diariamente, sem adornos como brincos e piercings.

É interessante notar o tom de autocrítica no discurso de Santos, ao colocar que os uniformes ainda tem um toque antigo, que vai contra a ideia de uma maior proximidade e interação com o cliente. 
A identidade visual do hotel, em relação à logotipia, material de papelaria, menus e outros materiais como estes são centralizados em Portugal. O objetivo é mostrar aos hóspedes que a Porto Bay é um grupo hoteleiro, e não apenas um conglomerado de investimentos pulverizados. Para isso, a harmonia visual, que Santos chamou de "fio condutor" é importante.

No entanto, o limite para essa harmonia visual é a localização do hotel, que tem que ter um toque adaptado à cidade. No caso do L'Hotel, alguns quadros que decoram as áreas comuns fazem menção a algum elemento da cidade de São Paulo.

A ilustração 72 exemplifica isso. É um quadro exposto no restaurante do hotel, onde pode ser visto claramente a escultura feita no Memorial da América Latina.

\section{Ilustração 72: Restaurante com o quadro sobre São Paulo}

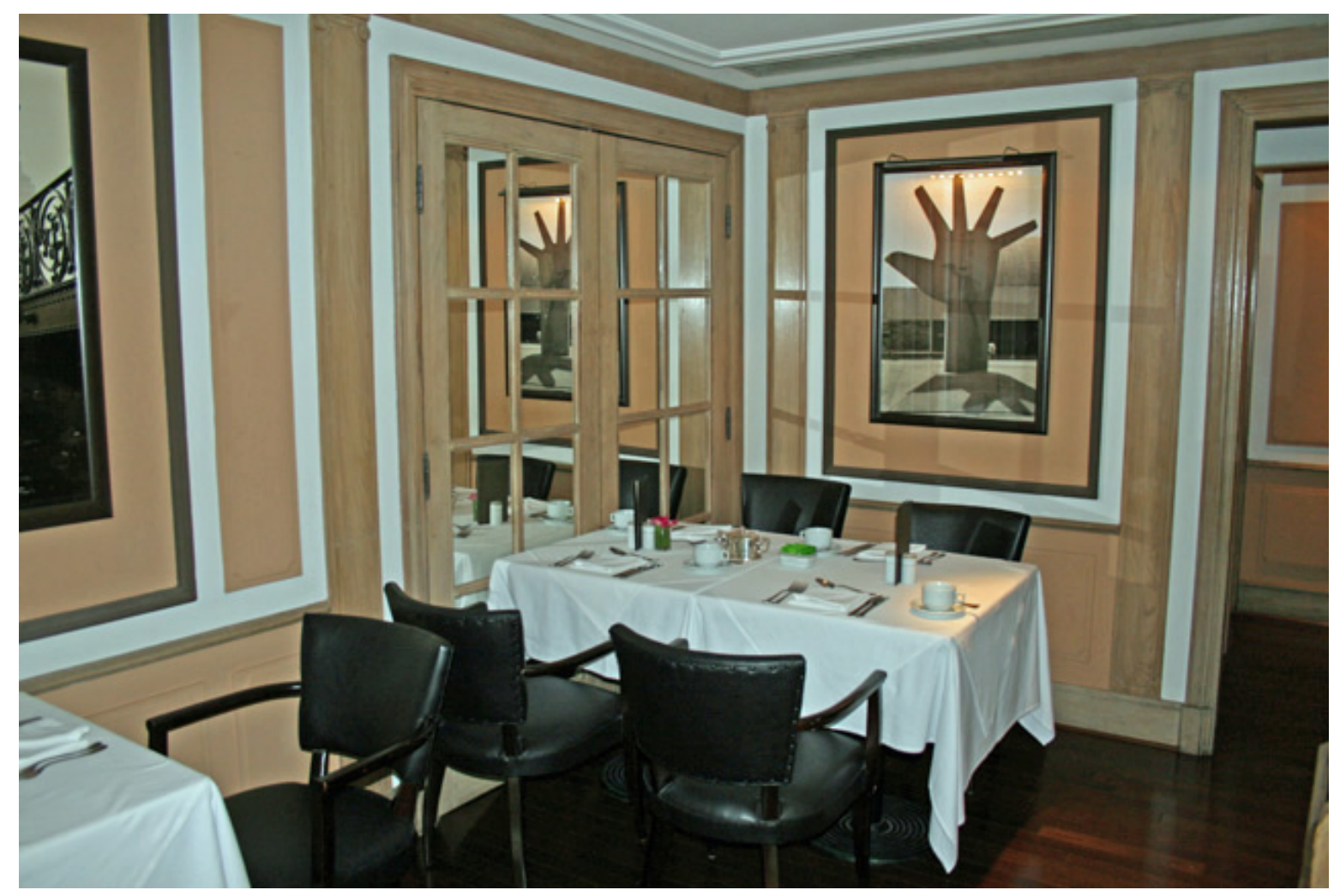

Fonte: foto tirada pelo autor, em visita realizada dia 19/11/2011

Para finalizar a questão visual, é interessante notarmos que existe uma preocupação não apenas com a sobriedade, refletida pelas cores usadas, móveis e iluminação, como também 
em alguns elementos da própria decoração, que seguem o mesmo estilo, e que em alguns pontos ganham um destaque pelas peças usadas.

A ilustração 73 é um exemplo disto. Nela, pode ser vista uma obra de tapeçaria que fica exposta no alto da escadaria existente no lobby do hotel, e que tem suas cores também em tons pastéis. Esta antiguidade faz parte do acervo do L'Hotel, e é o grande destaque do lobby.

\section{Ilustração 73: Tapeçaria do lobby}

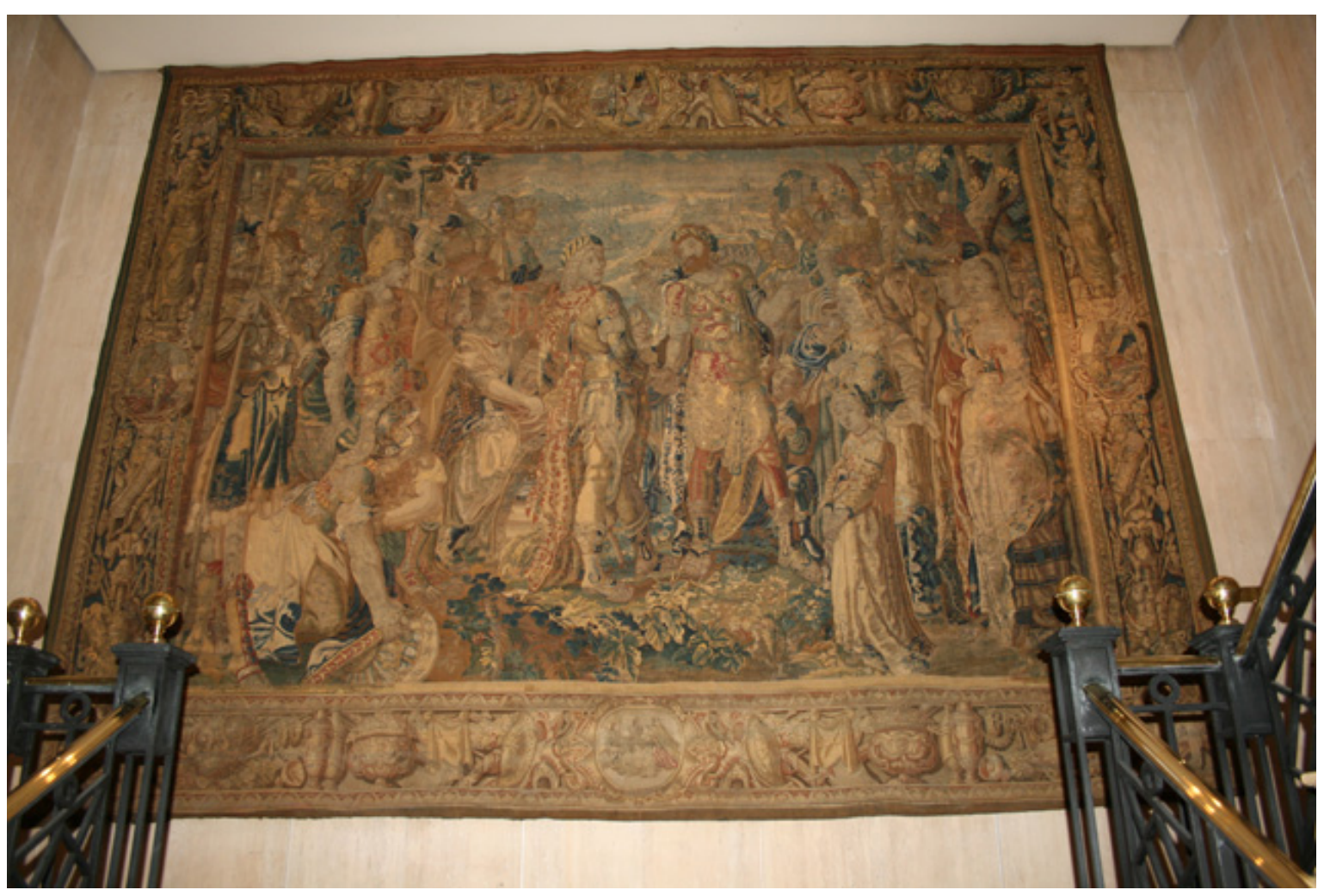

Fonte: foto tirada pelo autor, em visita realizada dia 19/11/2011

Outro exemplo dos elementos de decoração é o termômetro que também decora o lobby do L'Hotel. É um termômetro provençal datado de 1767, que é uma peça de coleção. Como visto nas ilustrações 74 e 75 , é uma peça que se adequa muito bem ao conceito de sobriedade passado, e que também se harmoniza com a tapeçaria exposta. 
Ilustração 74: Termômetro do lobby

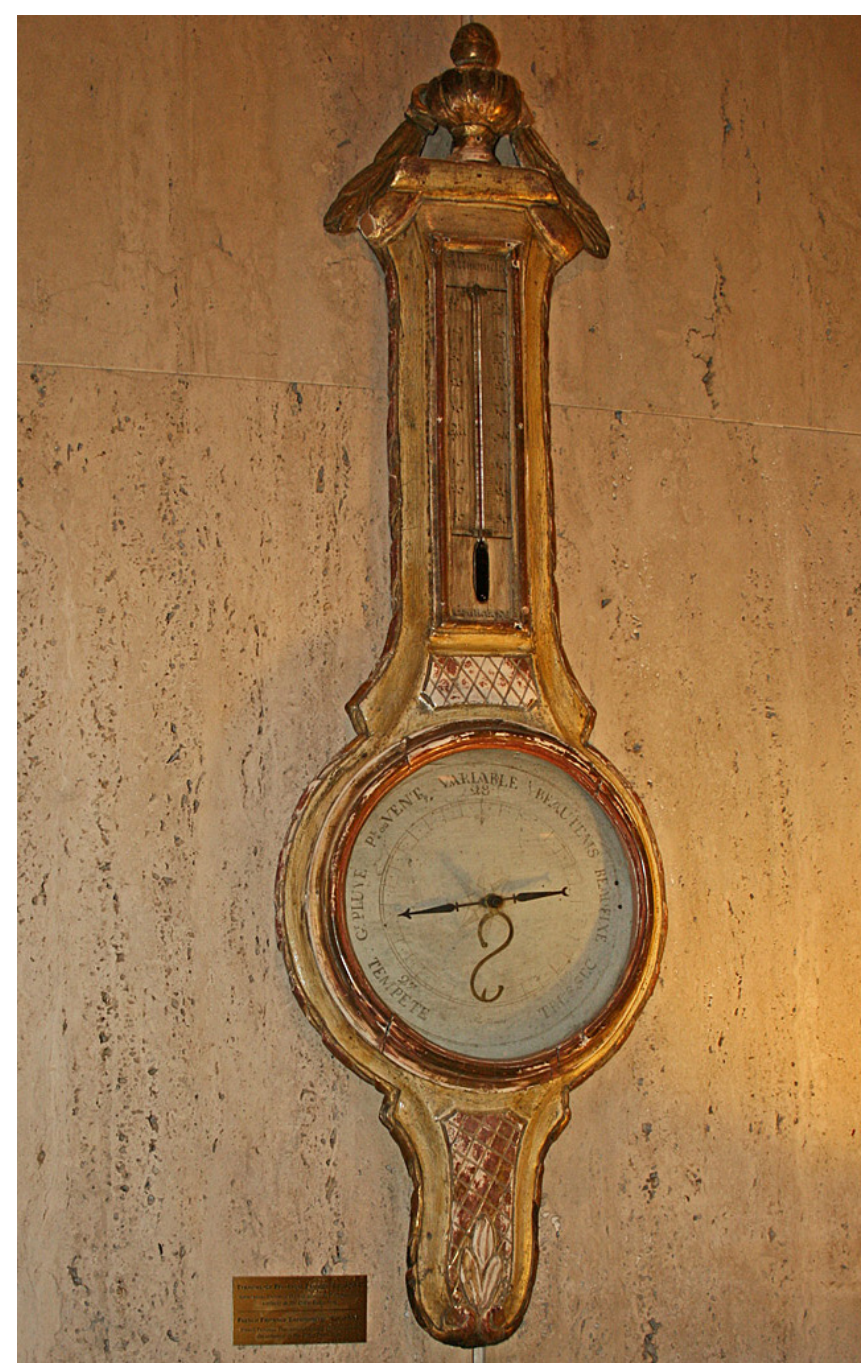

Fonte: foto tirada pelo autor, em visita realizada dia 19/11/2011

Ilustração 75: Placa referente ao termômetro do lobby

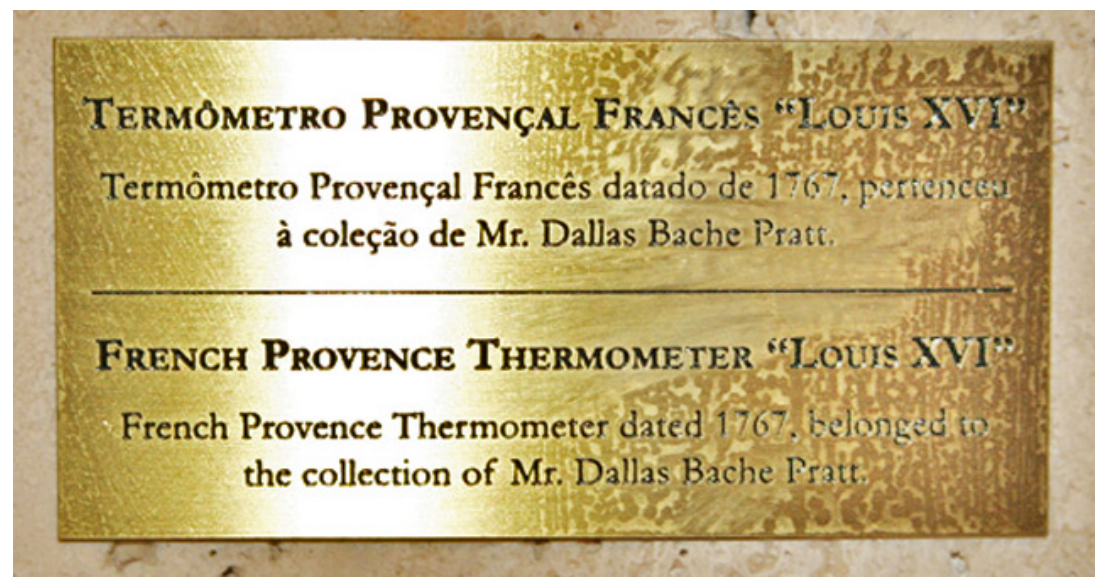

Fonte: foto tirada pelo autor, em visita realizada dia 19/11/2011 
Para finalizar a questão visual, além dos itens já mostrados, e que são mais explícitos, chama a atenção alguns pequenos detalhes que também estão de acordo com a proposta do hotel, criando uma harmonia em toda a decoração.

É o caso, por exemplo, de várias paredes e móveis, que não usam cores sólidas. Ao contrário, procura-se mostrar discretamente alguma textura, independente do material usado: o cimento da parede, a madeira dos móveis e os tecidos dos estofados. As ilustrações seguintes exemplificam isso.

A ilustração 76 mostra o criado-mudo dos quartos. Pode-se perceber o uso de três materiais diferentes, como madeira, palha e mármore, e todos seguem uma mesma tonalidade e tem algum tipo de textura.

\section{Ilustração 76: Criado-mudo dos quartos}

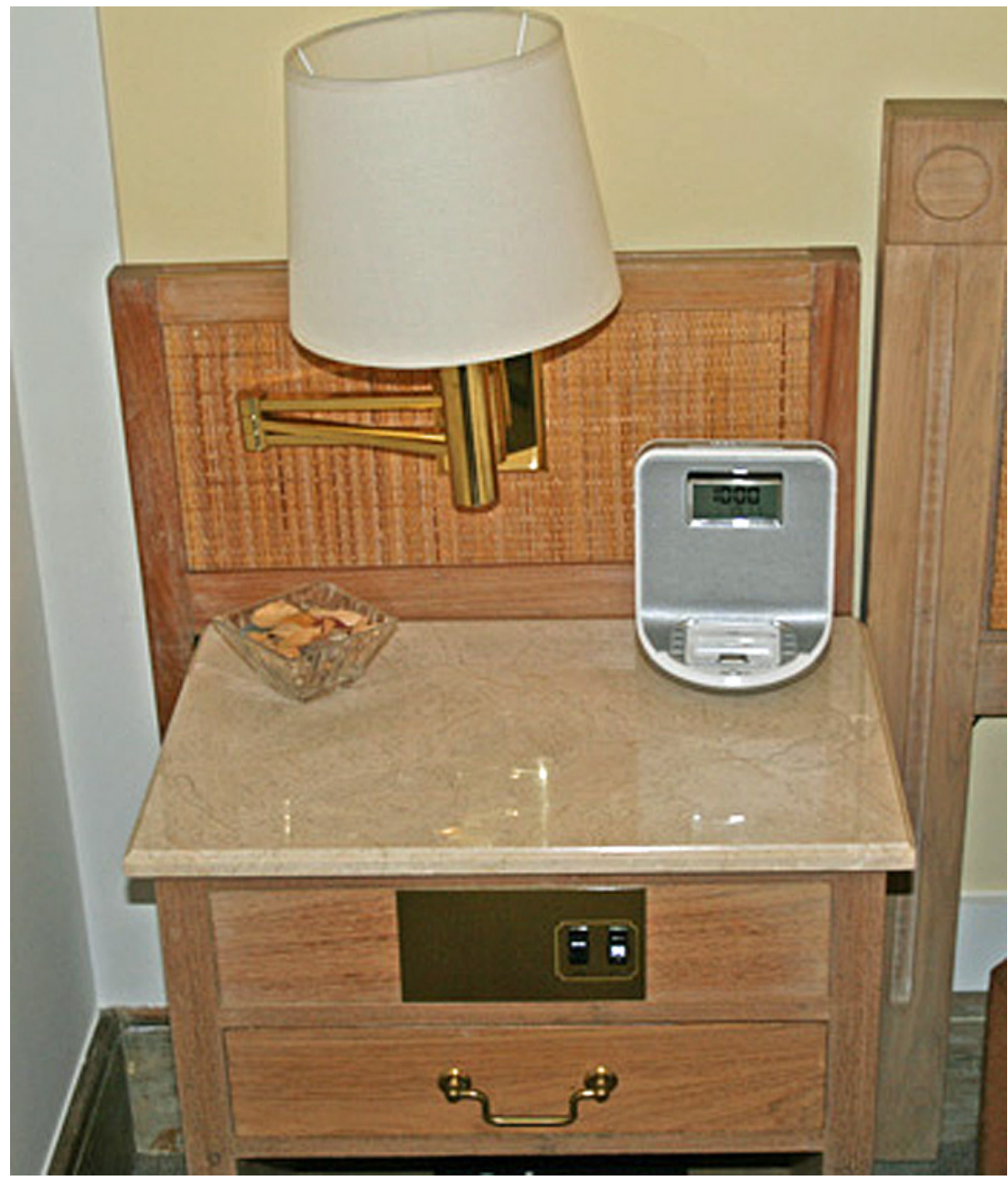

Fonte: foto tirada pelo autor, em visita realizada dia 19/11/2011 
Na ilustração 77 pode-se ver esta mesma ideia no hall dos elevadores que fica no lobby do hotel, onde a moldura da porta, feita em mármore, tem cor diferente, mas que se harmoniza com a parede, também de mármore. E, claro, por se usar mármore, a textura é evidente.

\section{Ilustração 77: Hall do elevador}

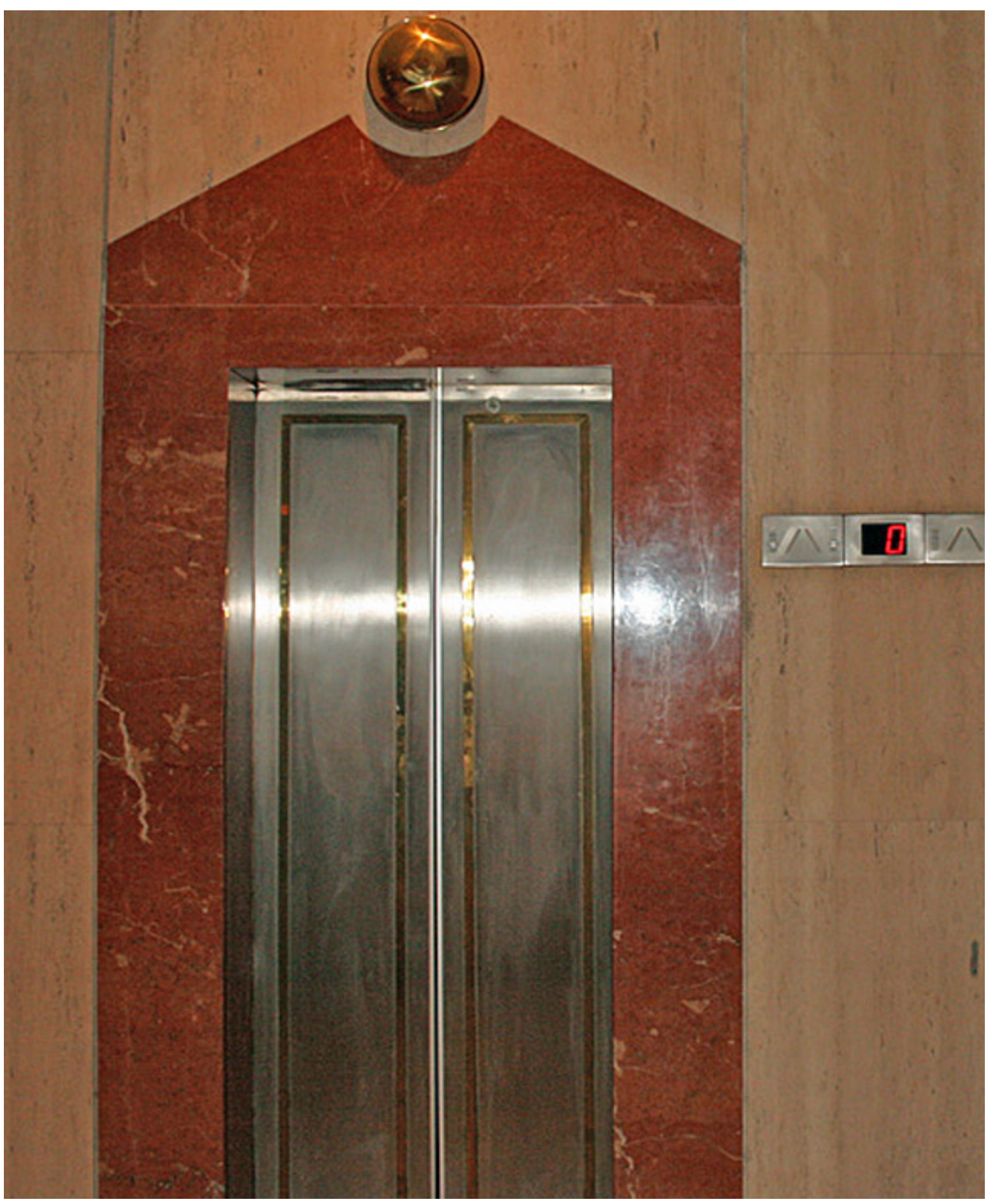

Fonte: foto tirada pelo autor, em visita realizada dia 19/11/2011 
Na ilustração 78 observa-se que o mesmo trabalho de textura é aplicado nas paredes do hall dos andares, onde também é trabalhada a mesma tonalidade de cores e iluminação. Com isso, fica evidente a harmonia cromática buscada pelo hotel, seguindo um conceito de sobriedade.

\section{Ilustração 78: Luminária e paredes do hall dos andares}

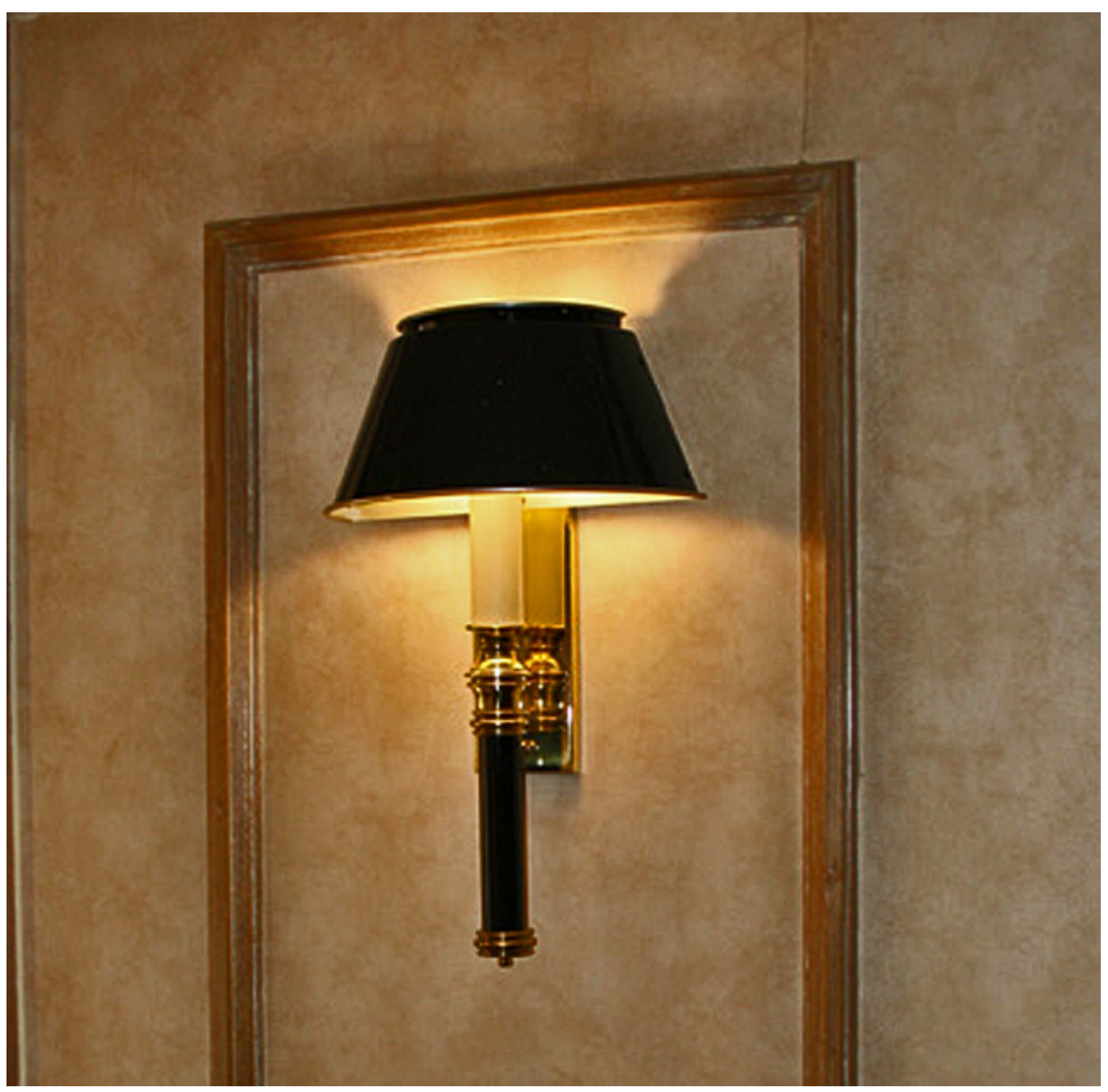

Fonte: foto tirada pelo autor, em visita realizada dia 19/11/2011

A questão visual tem um ponto que chama a atenção: por um lado, é fácil ver a preocupação do hotel com os aspectos visuais no que diz respeito aos quartos, áreas comuns, restaurante, lounge e academia. No entanto, essa mesma preocupação parece não existir na área de convenções. As salas de reunião e eventos destoam bastante das outras áreas do hotel em termos de arrumação, decoração e identidade visual. 
A ideia de algo mais clássico e sofisticado não fica evidente nas áreas do centro de convenções. Isto pode ser visto nas ilustrações a seguir.

A ilustração 79 mostra uma foto do centro de convenções, onde podemos ver o piso sem nenhum tipo de tapete ou carpete. As mesas e cadeiras são bastante simples, se comparadas com os móveis que decoram as outras áreas do hotel. As paredes também não tem nenhuma pintura especial, nenhuma textura, e não existe nenhum elemento de decoração além dos quadros. A iluminação é direta, reforçando uma sensação de frieza que destoa do restante do hotel.

\section{Ilustração 79: Centro de convenções}

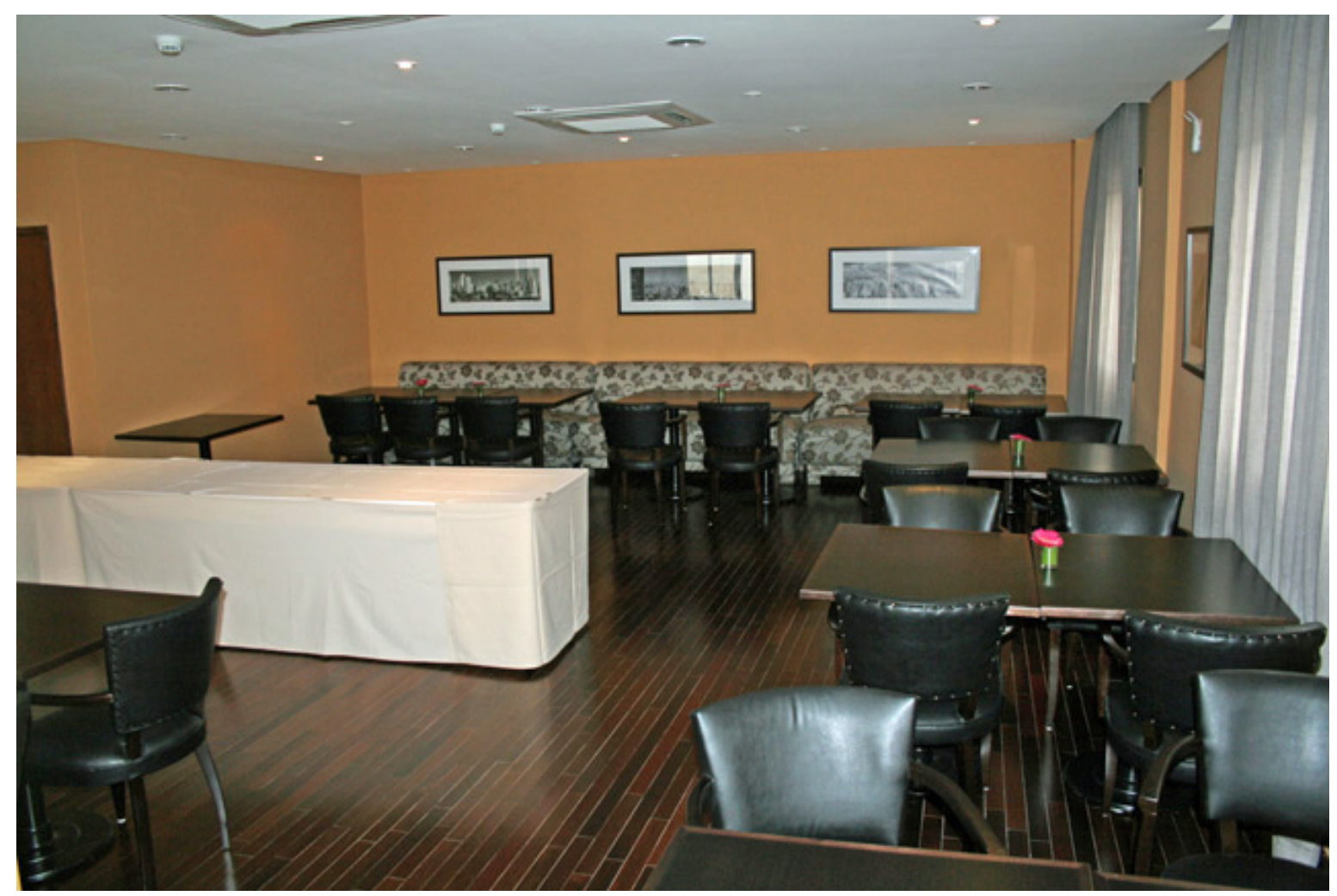

Fonte: foto tirada pelo autor, em visita realizada dia 19/11/2011

Já na ilustração 80 , a foto de uma sala de reunião mostra que tem as mesmas características, ou seja, apenas uma mesa com cadeiras simples, se comparados ao mobiliário do hotel. Também não existe nenhum elemento decorativo. Comparando com as outras áreas, podemos dizer que o aspecto visual da área de reuniões e convenções tem um estilo quase espartano, sem nenhuma identidade, e que difere significativamente do ambiente clássico e sofisticado que encontramos em outras áreas. 


\section{Ilustração 80: Sala de reunião}

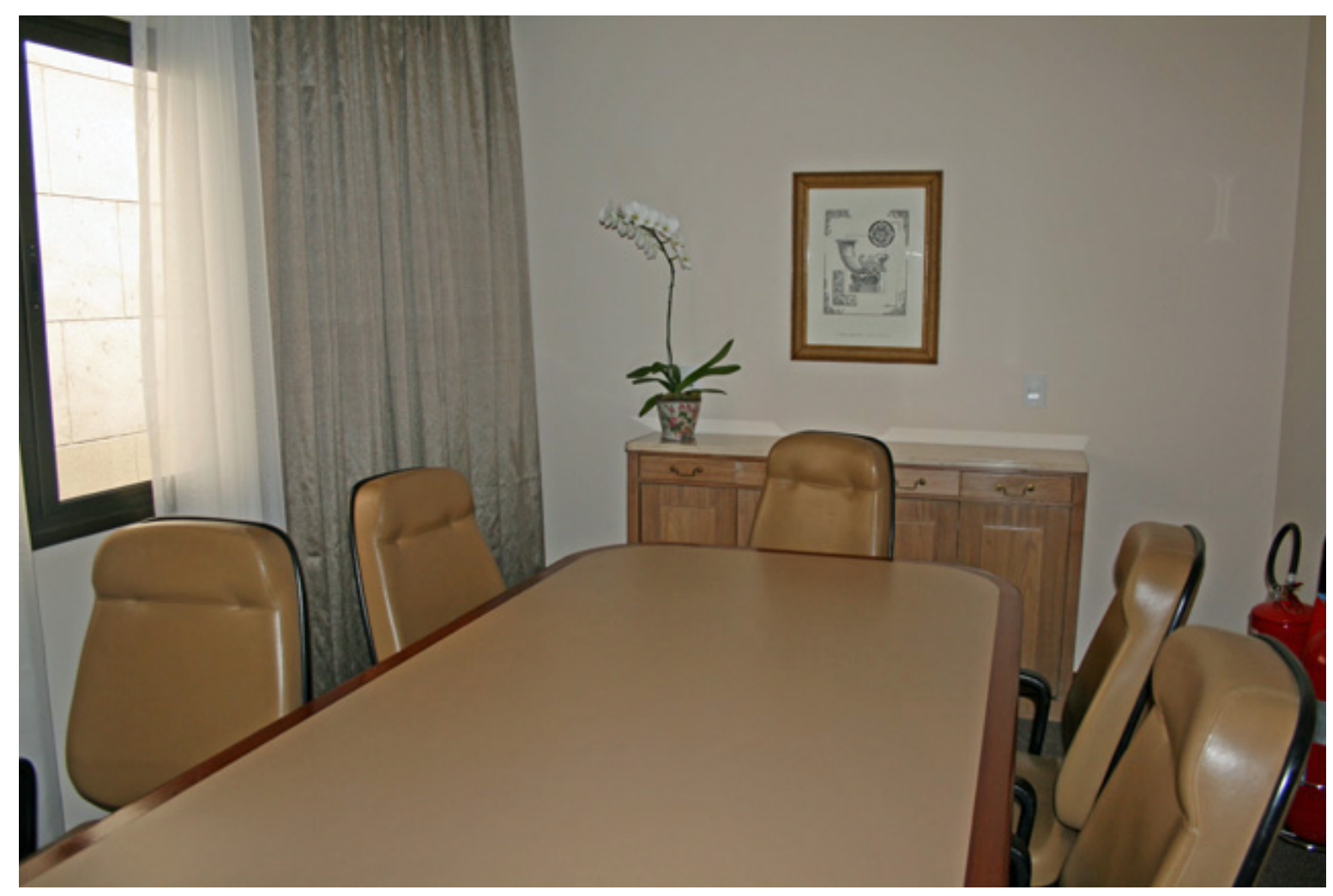

Fonte: foto tirada pelo autor, em visita realizada dia 19/11/2011

Por fim, a piscina (ilustração 81), que segue o mesmo conceito das outras áreas do hotel. É uma piscina pequena, climatizada, com teto retrátil, decorada com cadeiras e sofás confortáveis, evidentemente com almofadas impermeáveis.

O padrão visual desta área segue o que foi desenvolvido no restante do hotel, e merece destaque o fato da piscina ser cercada de velas que, quando acesas, criam um efeito visual extremamente bonito e aconchegante. 


\section{Ilustração 81: Piscina}

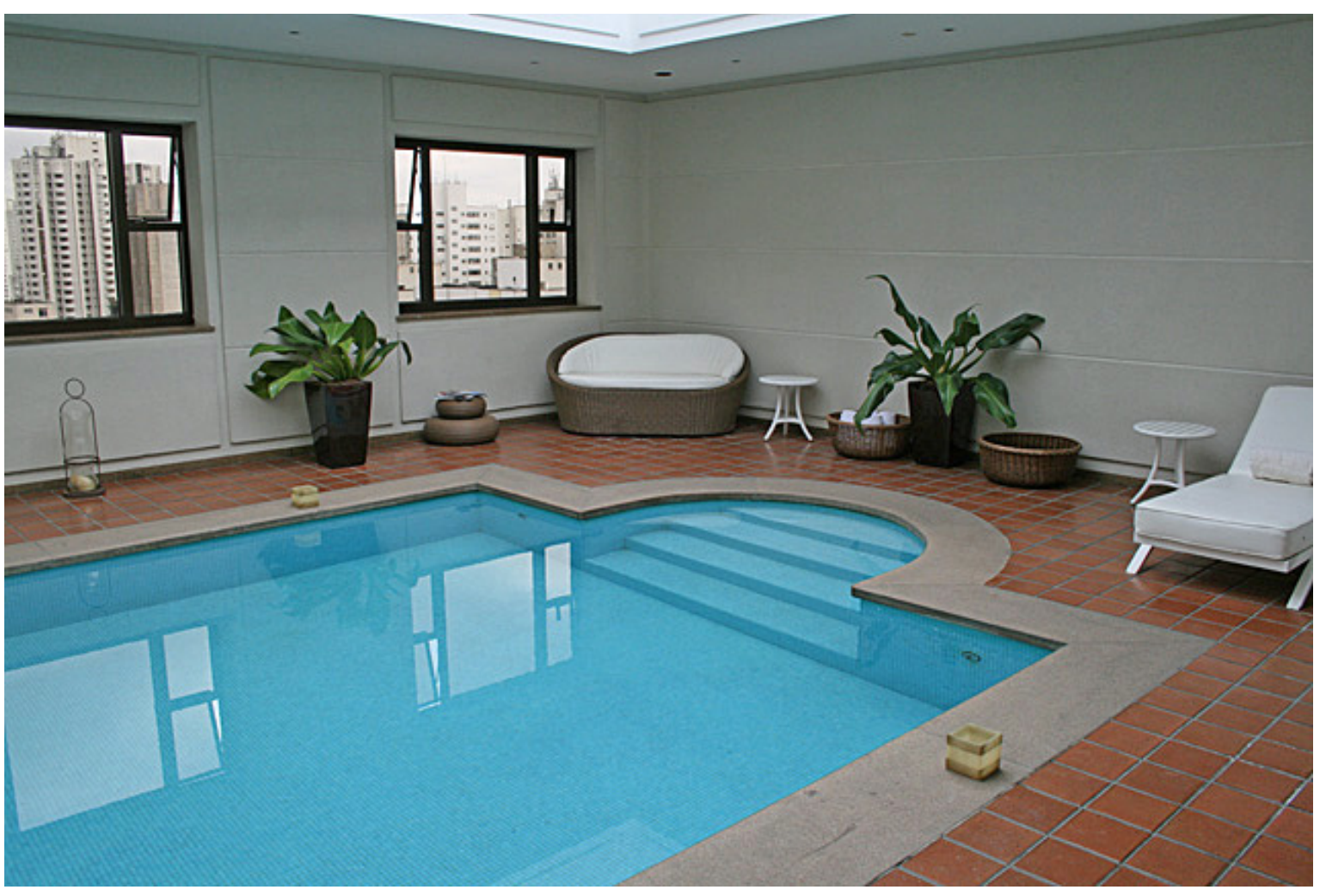

\section{Olfato}

Em relação ao olfato, o L'Hotel tem uma história interessante, segundo SANTOS (2011):

"a ideia foi copiada de um hotel de Roma. Estávamos eu e o presidente do grupo numa conferência em Roma, que tinha o patrocínio da Bulgari. Todos os ambientes tinham aquele mesmo perfume maravilhoso. Algum tempo depois, já em Portugal, passou uma pessoa com aquele perfume. Imediatamente lembramos do hotel de Roma."

Com isso surgiu a ideia de desenvolver um perfume próprio, e há cerca de cinco anos foi criado um aroma para o hotel do Rio de Janeiro. Os resultados foram positivos, e hoje o mesmo aroma é utilizado em todos os hotéis do grupo, incluindo o L’Hotel.

O aroma é o mesmo para todos os ambientes, e não tem nenhuma origem específica. Com base da história do hotel de Roma, o objetivo era desenvolver um aroma que fosse apreciado 
por todos, sem nenhum radicalismo, ou seja, é um aroma agradável, sem nenhum toque muito específico. Segundo SANTOS (2011) "queríamos apenas algo que ficasse na memória, e não que despertasse grandes paixões ou grandes ódios. A ideia era simplesmente criar memória”.

Para que essa aromatização de ambientes funcione corretamente, os funcionários recebem orientação quanto à aplicação do perfume, e todos conhecem o "cheiro" do hotel e os objetivos desta ação, pois faz parte do treinamento padrão do L'Hotel.

Como o resultado com o aroma desenvolvido foi positivo, o L'Hotel desenvolveu uma linha de produtos de higiene pessoal (shampoo, sabonetes e cremes), com o mesmo aroma. A linha é exclusiva da rede e, como vimos, foi desenvolvida pela L'Occitane, e é feita com produtos neutros, ou seja, adequados para todos os tipos de pele, reforçando o sentido do tato que explicamos anteriormente, quando citamos o consumo das amenities.

Isso mostra que é uma ação planejada, e que recebe certo grau de atenção, até mesmo por fazer parte do treinamento. Nas visitas realizadas foi notado que efetivamente todos os ambientes estavam aromatizados com o mesmo perfume, independente da área do hotel. Para alguns clientes que pedem, o hotel presenteia com pequenos frascos que, no entanto, não estão à venda.

A ilustração 82 mostra a linha de amenities desenvolvida, onde se percebem embalagens e frascos com os mesmos tons pastéis utilizados pelo hotel. O resultado, além do estímulo ao olfato com uma fragrância exclusiva que combina com todo o perfume do hotel, é uma harmonia visual também no banheiro dos apartamentos. 


\section{Ilustração 82: Produtos de higiene pessoal}

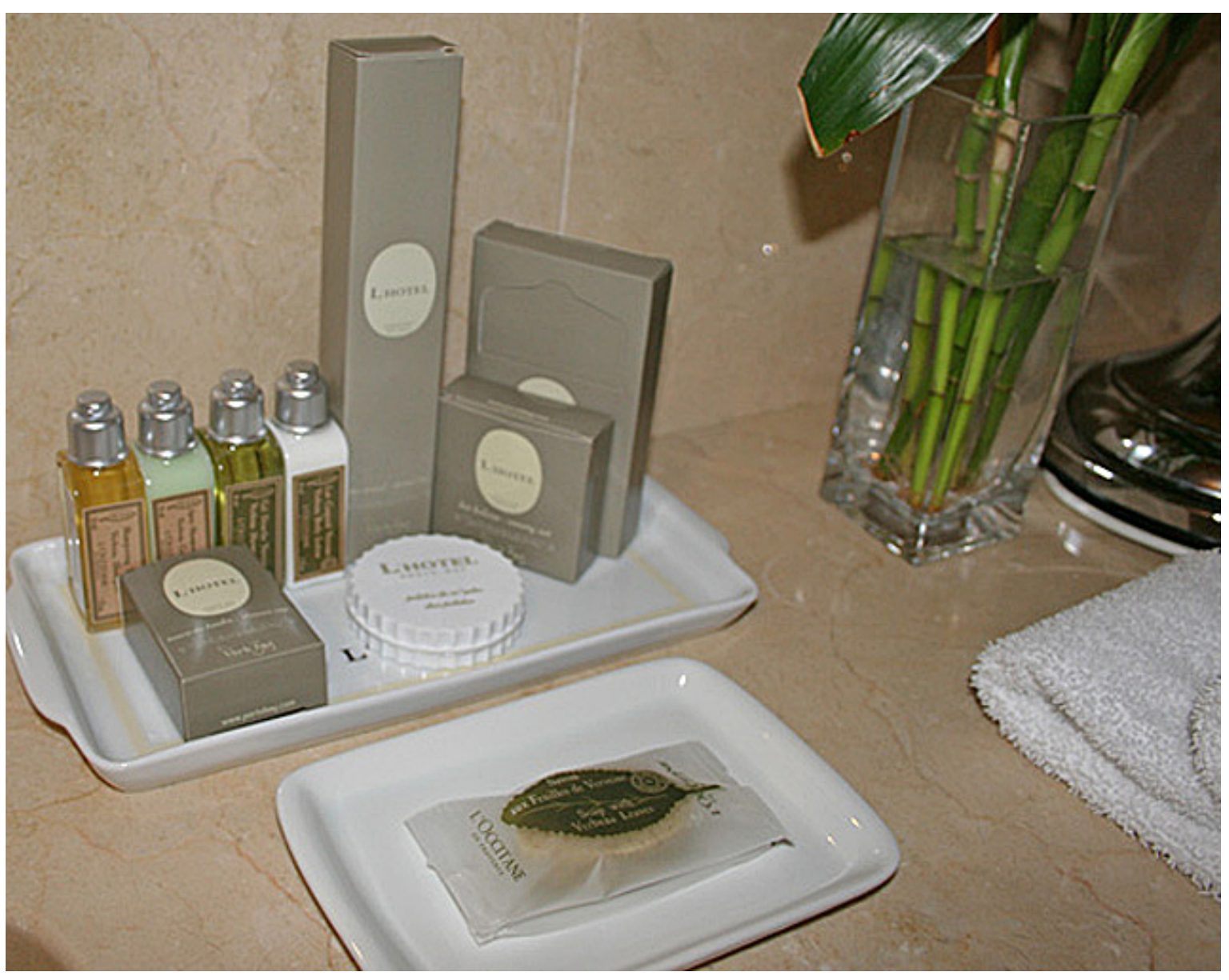

Fonte: foto tirada pelo autor, em visita realizada dia 19/11/2011

O planejamento de ações olfativas também foi explorado numa ação experimental feita no hotel do Rio de Janeiro, quando se ofereceu aos hóspedes a opção de usarem travesseiros aromatizados, a partir de um cardápio com 6 diferentes perfumes. A experiência não foi bem sucedida, pois os hóspedes não gostavam muito ou não se interessavam pela ideia, preferindo uma coisa mais neutra e, com isso, a experiência foi encerrada.

Isto é importante fundamentalmente por mostrar que o L'Hotel, ao menos em algumas de suas práticas, desenvolve ideias a partir de certo método, implantando e analisando resultados. Como visto no referencial teórico, isso é importante para ações de marketing como um todo, e para ações de marketing experiencial de maneira específica. 
Também em relação ao olfato, existe no hotel o tratamento normal de odores, principalmente na cozinha e áreas de serviço, com a colocação de equipamentos de exaustão e portas de contenção.

E, por fim, todos os funcionários recebem a mesma orientação dos outros hotéis analisados, qual seja, não usar perfume, e usar, preferencialmente, desodorantes neutros.

\section{Tato}

O sentido do tato pode ser percebido em algumas poucas ações que, no entanto, tem certa consistência com o conceito do hotel. A temperatura de todo o hotel, incluindo os quartos, está sempre regulada em $22^{\circ} \mathrm{C}$. Os lençóis são feitos de algodão de 600 fios, e são importados do Egito. Segundo o entrevistado, isso gera um enorme trabalho para lavar, e tem um alto custo.

Os travesseiros das suítes são de plumas de ganso, e os dos quartos são de outro material, mas também extremamente macios. Além disso, o hotel tem travesseiros de espuma antialérgica para os hóspedes que solicitam. As toalhas dos banheiros, bem como o roupão tem espessura determinada, e devem ser felpudas e macias. Os colchões são de padrão americano, também macios.

Segundo SANTOS (2011), "estes são os itens mais importantes que o hotel deve se preocupar em relação ao tato - colchão, roupa de cama e de banho é fundamental para a percepção de qualidade de um hotel."

$\mathrm{Na}$ ilustração 83 observa-se essa preocupação. Os travesseiros são grandes e passam efetivamente a ideia de algo macio e aconchegante. Além disso, são colocados quatro em cada cama e, da forma como são dispostos, a sensação de aconchego fica mais explícita. Nesta foto também pode ser reforçado o que foi demonstrado em relação ao aspecto visual, destacando a textura da cabeceira da cama. 


\section{Ilustração 83: Travesseiros e roupa de cama}

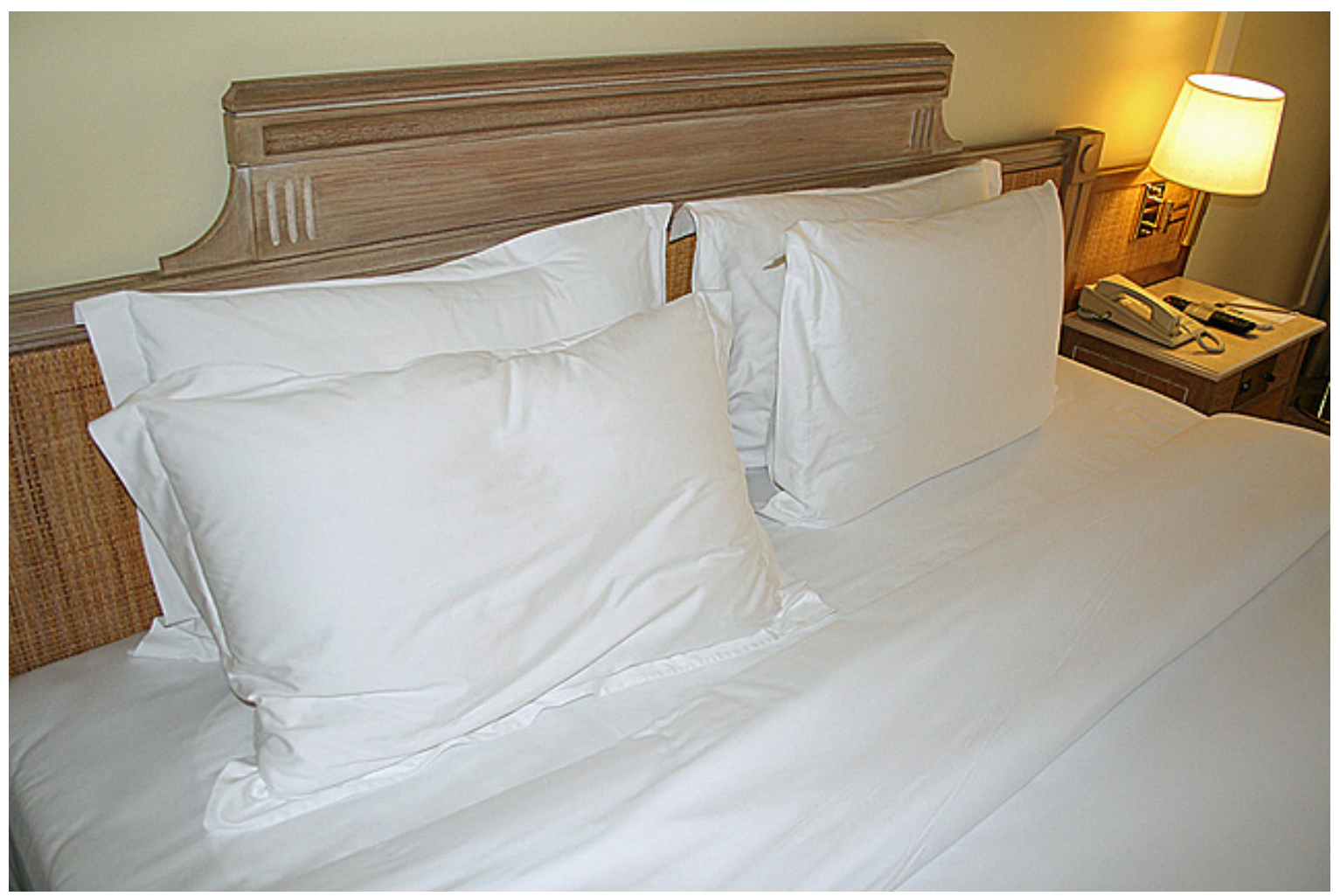

Fonte: foto tirada pelo autor, em visita realizada dia 19/11/2011

Nas ilustrações 84 e 85 nota-se a roupa de banho, que também passa a ideia de maciez, e onde podemos ver no detalhe a questão da espessura dos fios. Ressalte-se que tanto a roupa de cama, como a roupa de banho são brancas, não apenas para passar a imagem de limpeza, como também por ser uma cor neutra para estes produtos, conforme já explicado anteriormente.

Especificamente na ilustração 85 observam-se dois outros detalhes que tem a ver com o sentido da visão. Em primeiro lugar, nota-se que a textura que mostrada em alguns itens também aparece aqui, na porta do quarto. É uma madeira cuja pintura ressalta uma textura neutra, clássica.

Em segundo lugar, percebe-se que a arrumação do roupão de banho obedece a um critério que passa a ideia de cuidado, na medida em que não está apenas pendurado num cabide, mas sim amarrado de um jeito especial. 
Esse pequeno detalhe reforça a ideia de proximidade com os hóspedes que o L'Hotel procura passar, pois gera a percepção de que alguém efetivamente teve cuidado ao colocar aquele roupão, daquela maneira, naquele local.

\section{Ilustração 84: Toalhas de banho}

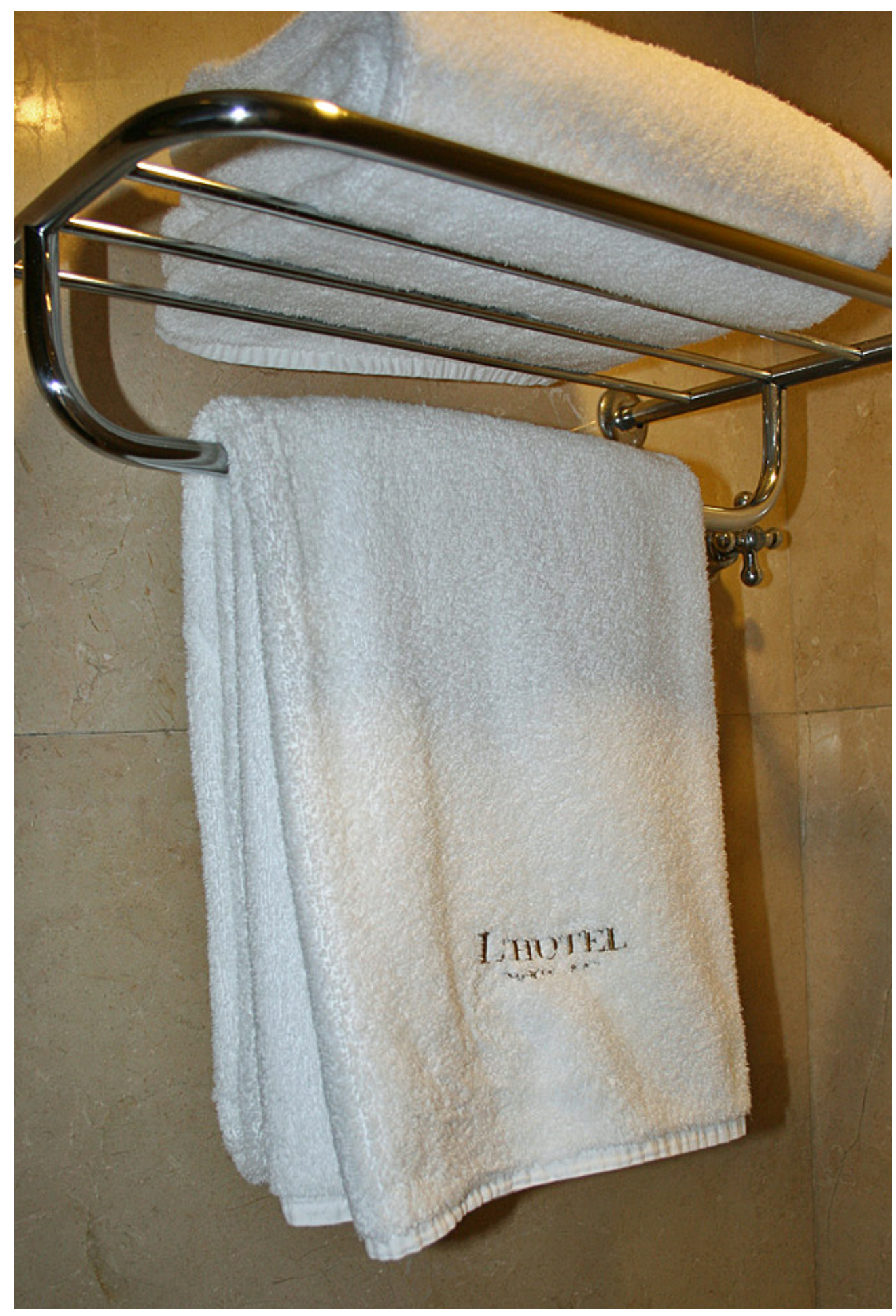

Fonte: foto tirada pelo autor, em visita realizada dia 19/11/2011 


\section{Ilustração 84: Roupão de banho}

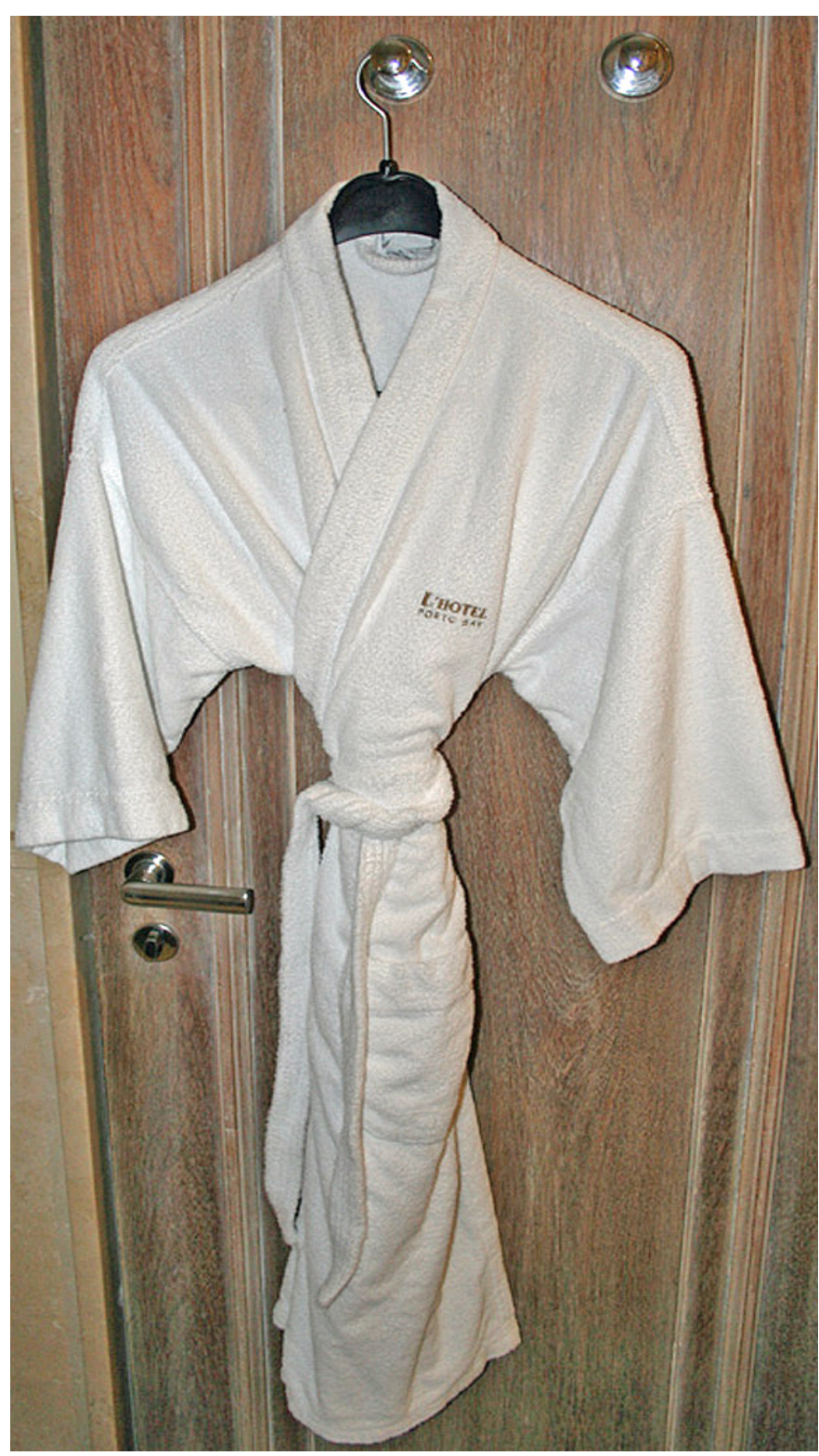

Fonte: foto tirada pelo autor, em visita realizada dia 19/11/2011

O sentido do tato também é explorado no chuveiro, que tem uma ducha de grande vazão, como visto na ilustração 86 . Este é um ponto que também é importante num hotel desta categoria. Nesta imagem também se percebe que o banheiro é feito de mármore que, como já mostrado, é padrão para hotéis de luxo. 


\section{Ilustração 86: Chuveiro dos quartos}

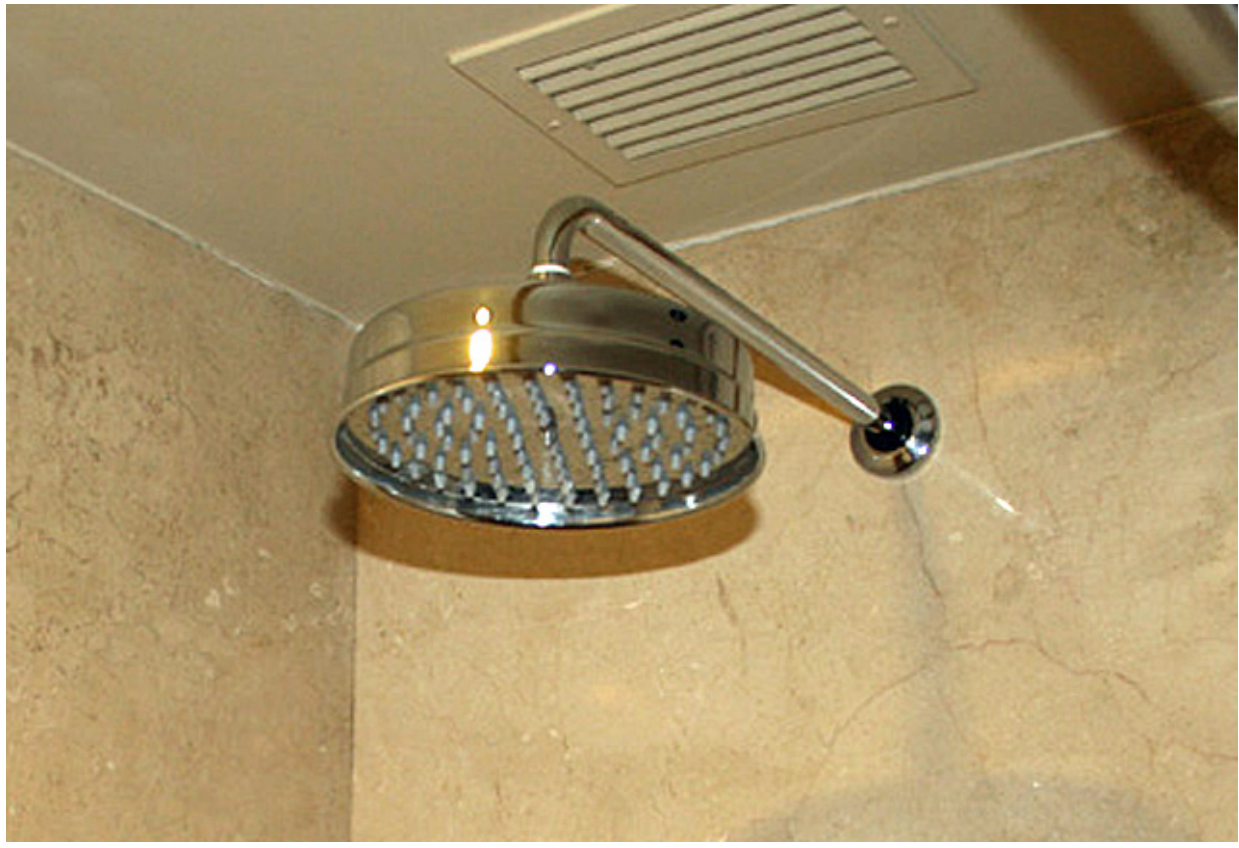

Fonte: foto tirada pelo autor, em visita realizada dia 19/11/2011

Por fim, em relação ao tato, podem ser destacados também os serviços oferecidos pelo spa que, de uma maneira ou de outra, a partir de sessões de massagem, sauna e ofurô, geram sensações táteis.

No caso do L'Hotel, o spa é basicamente composto por banheiras de ofurô, sauna e sala para massagem, como podemos ver nas ilustrações a seguir.

A ilustração 87 mostra as banheiras de ofurô. Pode ser percebido que os outros elementos já analisados do sentido da visão também se fazem presentes aqui, com a decoração usando as mesmas tonalidades, o uso de materiais como a madeira, que tem uma textura agradável, além da forma como estão arrumados os roupões, chinelos e toalhas. 
Ilustração 87: Banheiras de ofurô

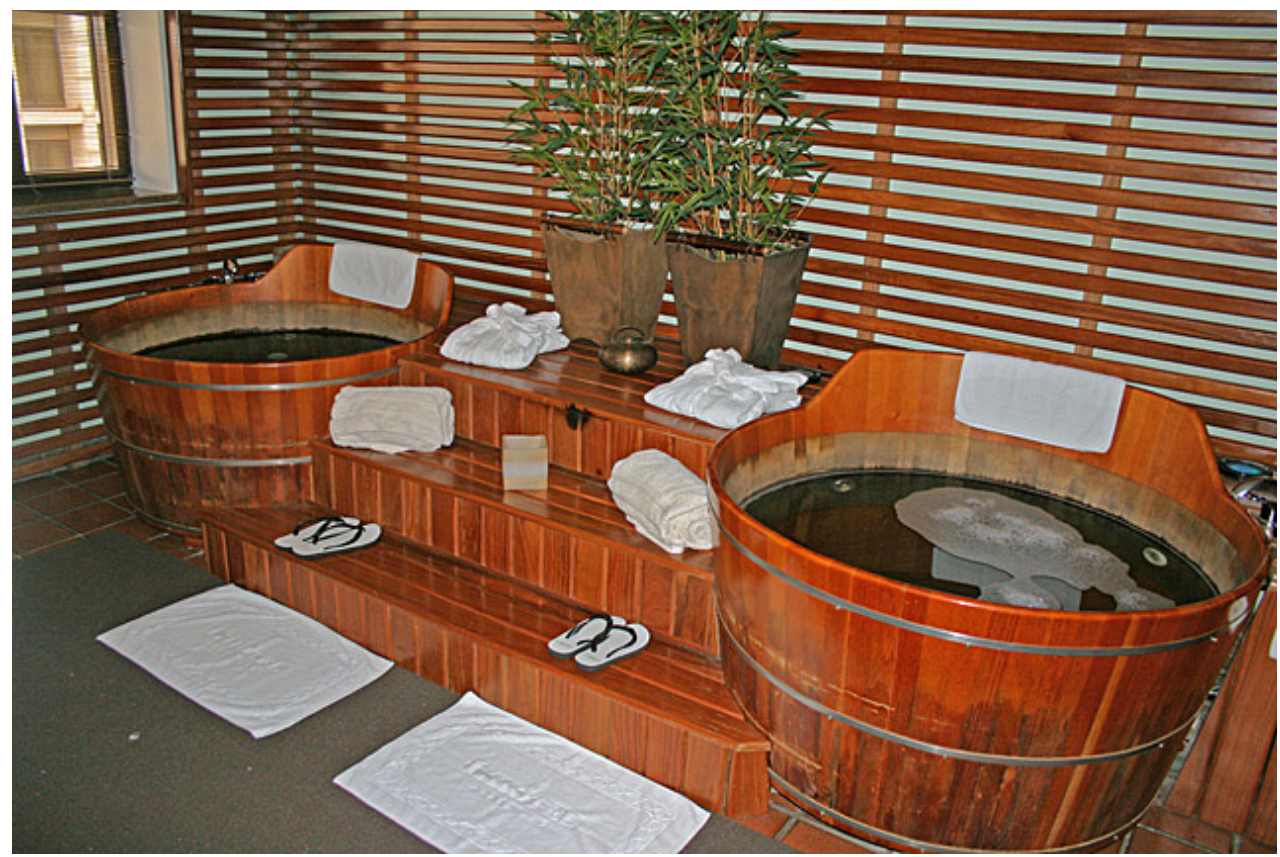

Fonte: foto tirada pelo autor, em visita realizada dia 19/11/2011

Já na ilustração 88 , pode ser vista a foto da cadeira de massagem, que fica numa sala anexa às banheiras de ofurô. Todo o ambiente do spa, localizado no mesmo andar da piscina, procura despertar, a partir do seu visual, a vontade para que o hóspede faça algum dos tratamentos oferecidos, o que acaba por estimular o sentido do tato.

\section{Ilustração 88: Cadeira de massagem}

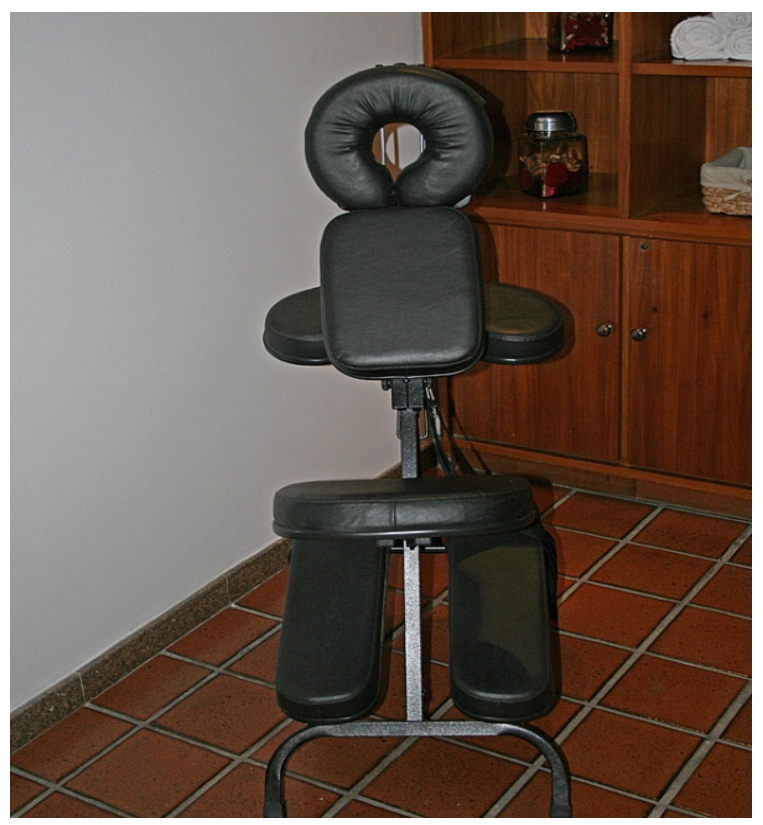

Fonte: foto tirada pelo autor, em visita realizada dia 19/11/2011 


\section{Paladar}

O sentido do paladar é trabalhado de maneira simples e discreta, com poucas ações. O L'Hotel tem apenas um restaurante, que funciona para as três refeições. O cardápio do almoço tem um menu executivo, e sempre existe uma opção de comida mais light. Não existe nenhuma obrigatoriedade em termos de pratos - a única recomendação é que sempre haja algum prato da culinária portuguesa, para fazer uma ligação com a origem do grupo.

$\mathrm{Na}$ área do spa, conforme a ilustração 89 mostra, existe uma mesa onde os hóspedes tem à disposição uma bandeja de frutas e garrafas de água gelada, o que não deixa de ser um apelo para o sentido do paladar.

A questão aqui é que esta mesa tem muito o intuito de ser mais um serviço agregado do SPA do que propriamente uma ação sensorial.

\section{Ilustração 89: Mesa com frutas e água}

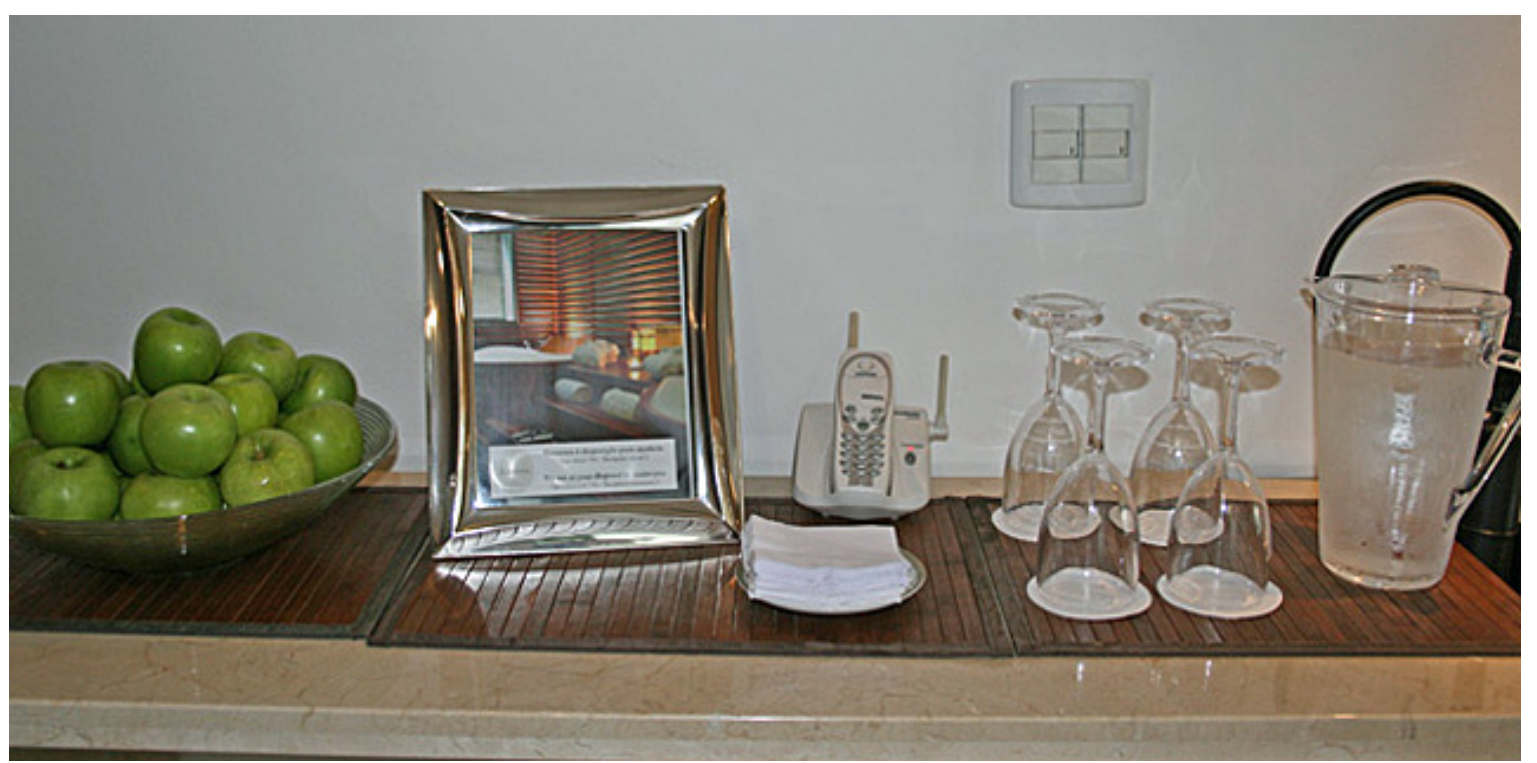

Fonte: foto tirada pelo autor, em visita realizada dia 19/11/2011

O frigobar existente nos quartos oferece certa variedade de produtos procurando agradar diferentes gostos. Esta variedade é trocada a cada 6 meses em função dos itens que tem maior saída. 
Se observadas as ilustrações seguintes, nota-se que os itens da lista de comidas e bebidas seguem esta recomendação de buscar maior diversificação. Na ilustração 90 são vistas as opções de comidas, com equilíbrio entre doces e salgados. Na ilustração 91 nota-se uma foto do frigobar, com diferentes tipos de bebidas, incluindo vinho, água, refrigerante, chá, energético e água de coco. É visível também que as marcas ofertadas são reconhecidas como marcas de qualidade, compatíveis com o nível do hotel.

\section{Ilustração 90: Itens comestíveis do frigobar dos quartos}

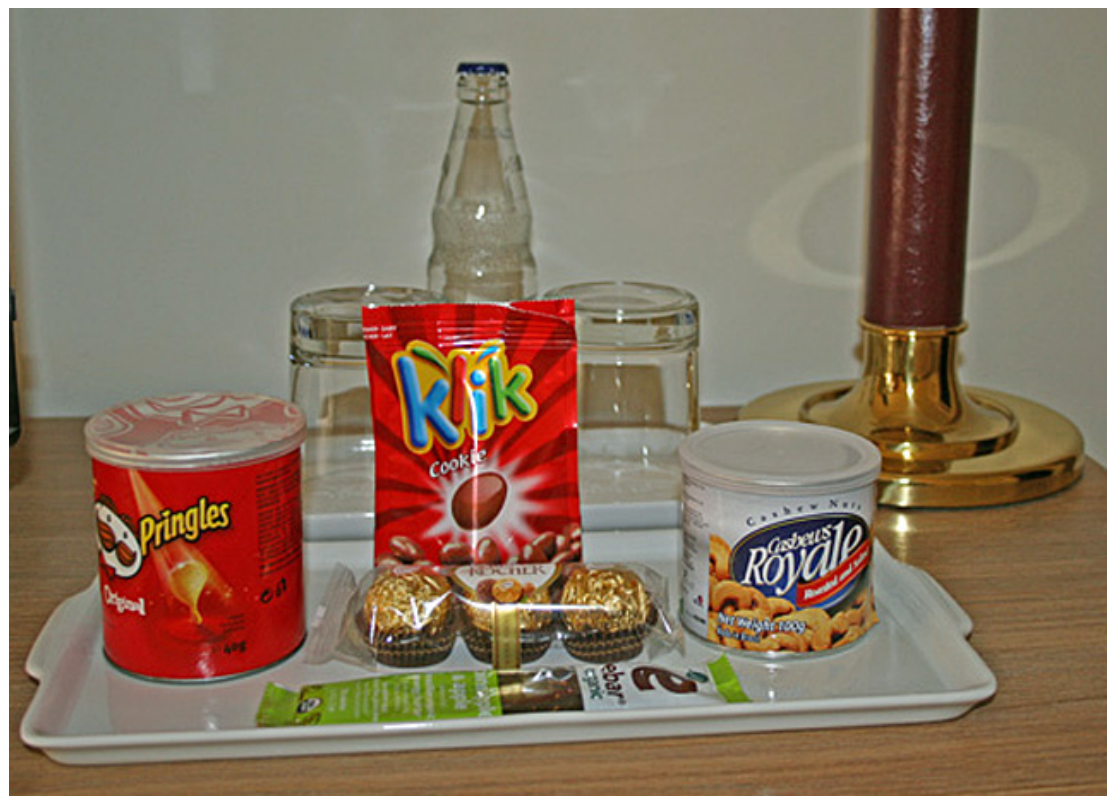

Fonte: foto tirada pelo autor, em visita realizada dia 19/11/2011

Ilustração 91: Bebidas do frigobar dos quartos

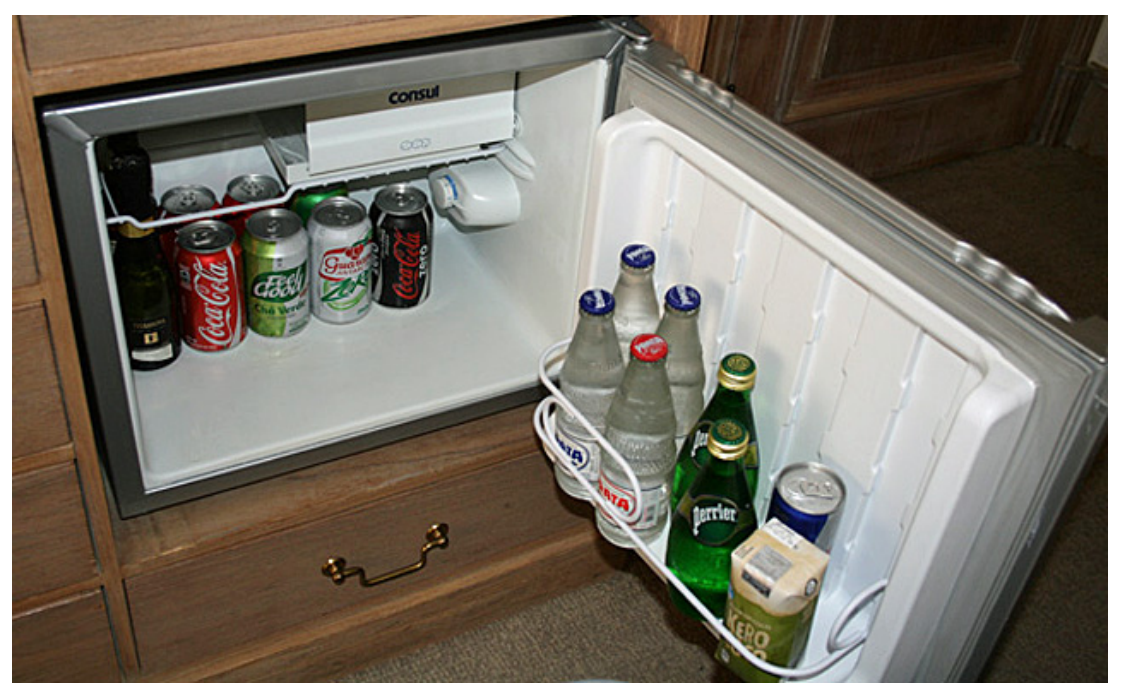

Fonte: foto tirada pelo autor, em visita realizada dia 19/11/2011 
Na questão do paladar, o destaque é para o café da manhã do hotel, bastante elogiado nas avaliações do TRIP ADVISOR (2011). Como visto nas ilustrações 92 e 93, é uma mesa bastante farta, cuidadosamente decorada, e com vários itens que não fazem parte de um tradicional café da manhã, como espumante e salmão, por exemplo. Existe uma grande diversidade de pães, frutas, queijos e frios que vai além daquilo que é encontrado nos outros hotéis pesquisados.

Além dos itens que fazem parte do cardápio, destaca-se a arrumação das mesas e a disposição dos alimentos no buffet. Percebe-se um cuidado com a parte visual não apenas com itens de decoração, mas também com a arrumação dos alimentos. Os pratos são de porcelana, e todos tem a marca do L'Hotel. Além disso, existe a identificação em 2 idiomas de cada um dos pratos ali servidos.

Ilustração 92: Mesa de café da manhã 1

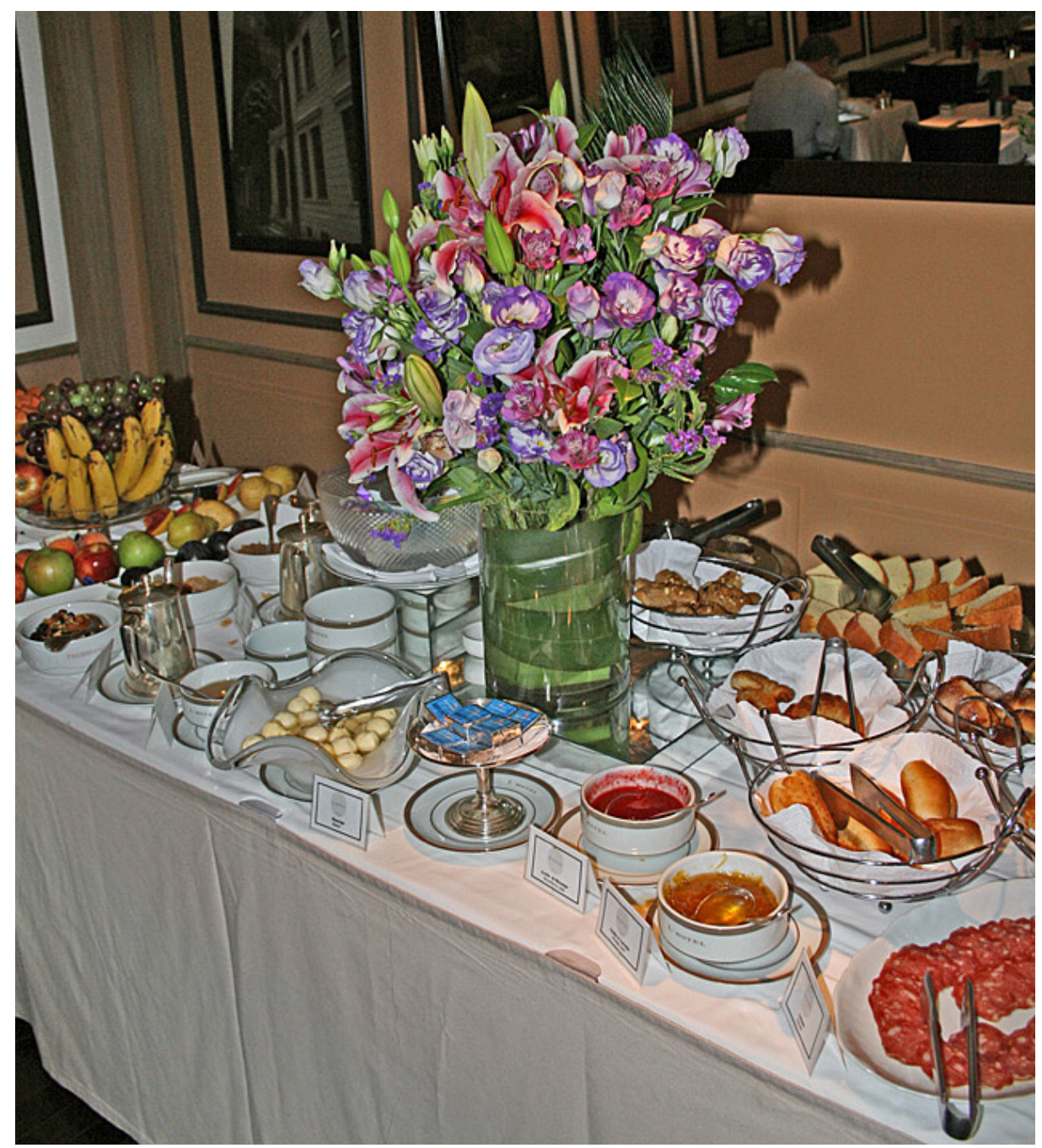

Fonte: foto tirada pelo autor, em visita realizada dia 19/11/2011 


\section{Ilustração 93: Mesa de café da manhã - 2}

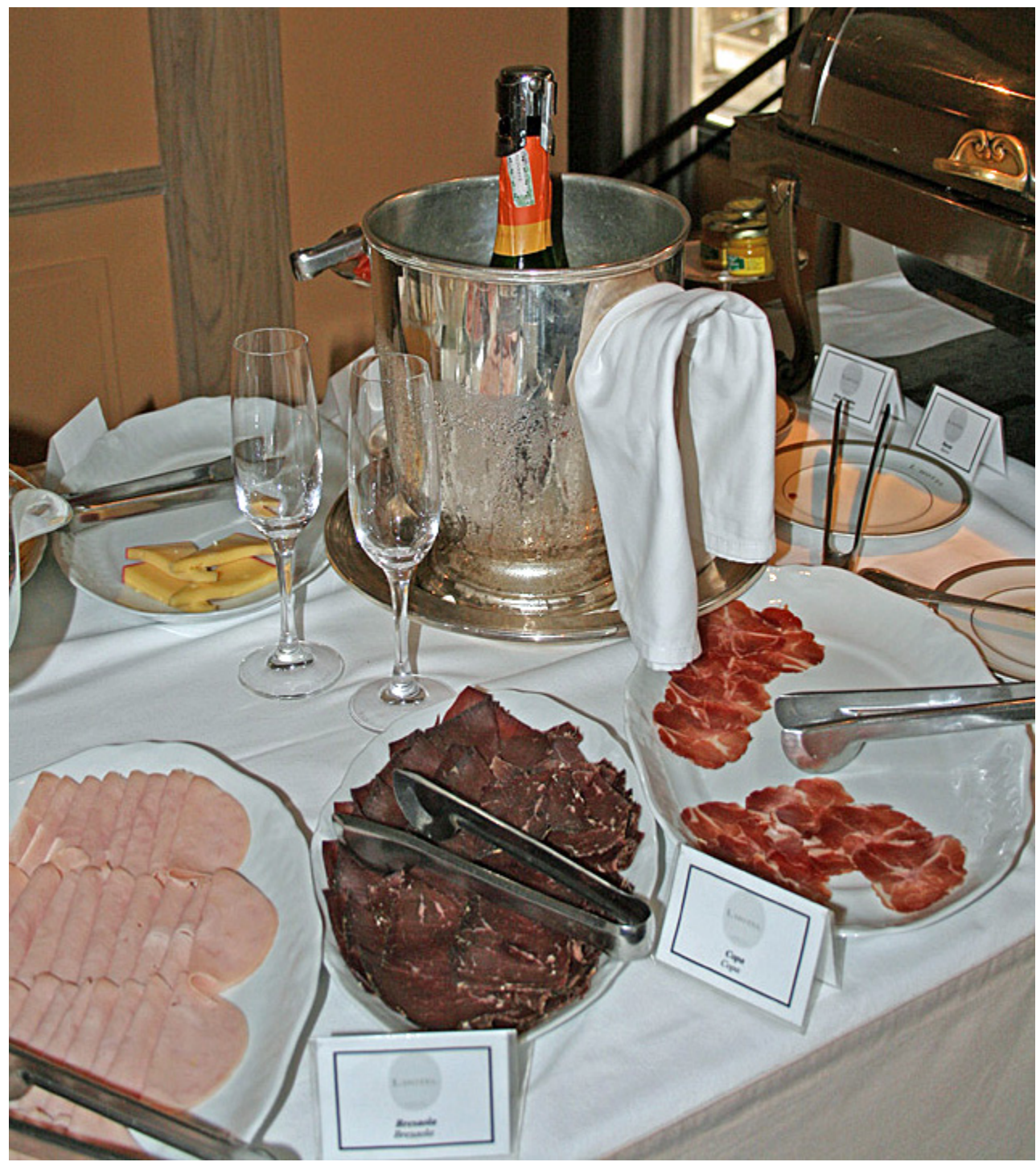

Fonte: foto tirada pelo autor, em visita realizada dia 19/11/2011

Para finalizar a questão do paladar, existem mais duas ações que merecem ser destacadas. $\mathrm{Na}$ recepção do hotel fica uma garrafa de espumante gelada, para que se ofereça uma taça aos hóspedes, no momento do check in, como vemos na ilustração 94. Segundo SANTOS (2011), esta ação é bastante valorizada pelos clientes.

A avaliação desta ação é contrária à avaliação feita pelo hotel Hilton, que desistiu de oferecer um drink de boas vindas. Como os hotéis tem perfis de público bastante parecidos, parece razoável imaginar que as opiniões diferentes não tem como causa o perfil dos hóspedes, mas sim alguma outra variável que não foi objeto de estudo desta tese. 


\section{Ilustração 94: Recepção com o espumante de boas-vindas}

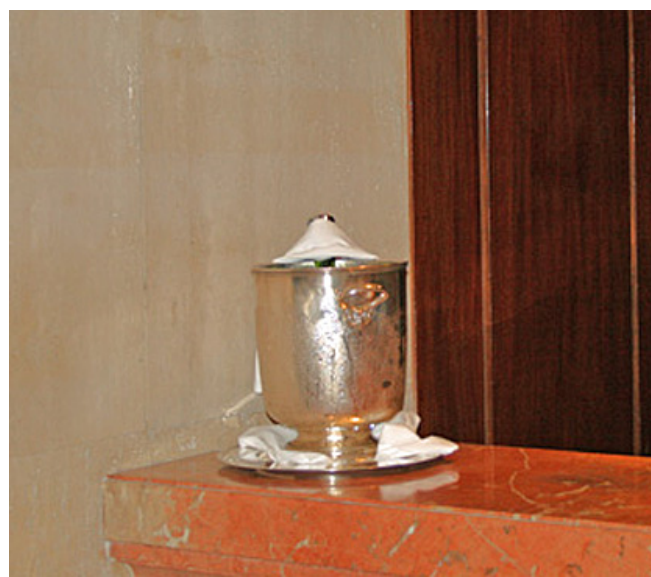

Fonte: foto tirada pelo autor, em visita realizada dia 19/11/2011

Outra ação desenvolvida pelo L'Hotel, apenas para hóspedes mais frequentes, é a colocação nos apartamentos uma bandeja de frutas e garrafas de água mineral, como brinde de boasvindas.

Finalmente, o L'Hotel também coloca no apartamento de hóspedes especiais, uma pequena bandeja de doces. Isto é feito no final da tarde, para que o hóspede encontre a lembrança quando for se deitar. Uma foto desta ação pode ser vista na ilustração 95.

\section{Ilustração 95: Bandeja de doces colocada nos quartos à noite}

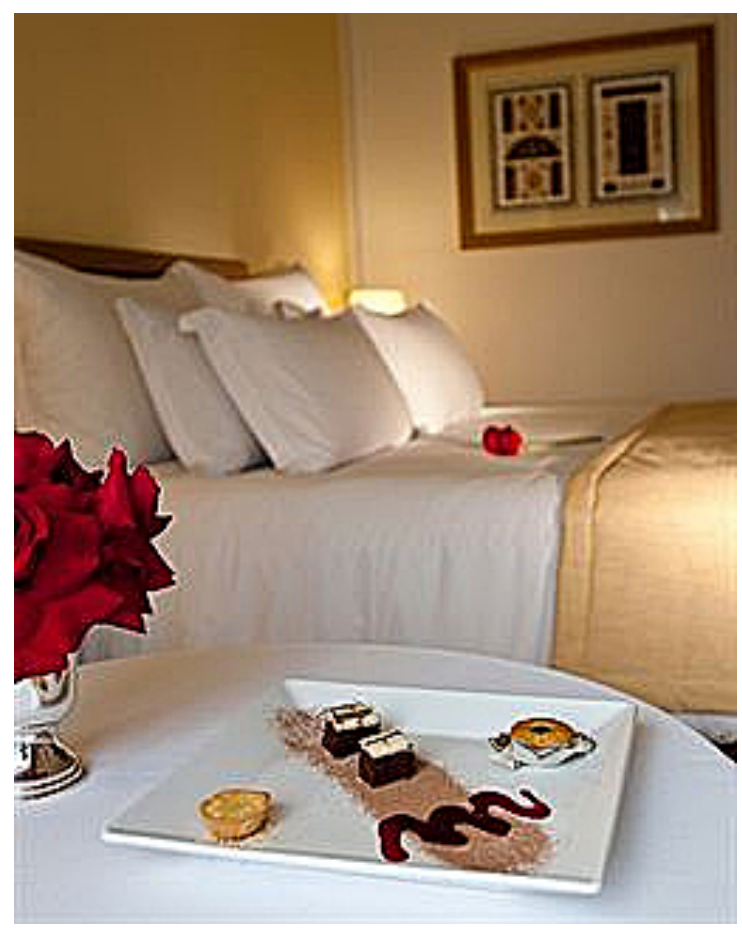

Fonte: Trip Advisor (2011) 


\section{Audição}

A audição talvez seja o sentido onde é menos perceptível alguma ação específica, como já visto na análise dos outros hotéis. No L'Hotel este sentido é trabalhado também seguindo a ideia do hotel em ter características da cidade onde está. Dentro deste conceito, existe música ambiente nas áreas comuns, e a seleção de músicas é feita especialmente para cada hotel, e produzida pelo próprio L'Hotel. Sendo assim, no hotel do Rio de Janeiro existe a predominância de bossa nova, enquanto que no hotel de São Paulo o que predomina é o jazz. Existe o cuidado para que a música seja apenas instrumental.

Em relação aos funcionários, não existe nenhum script formal. A recomendação é para que os funcionários tratem todos os hóspedes por Senhor e Senhora, procurando sempre usar o último nome. Isto também reforça a ideia de contato mais estreito com o hóspede, pois o tratamento pelo nome claramente cria a percepção de um serviço mais customizado.

Dentro dos apartamentos existe aparelho de som em formato digital, que é também um relógio. O fato deste equipamento ter entrada para aparelhos como os iPod's proporciona aos hóspedes a oportunidade de ouvirem suas músicas como som ambiente do apartamento. A ilustração 96 mostra uma foto deste aparelho, que fica no criado-mudo dos quartos.

\section{Ilustração 96: Aparelho de som dos quartos}

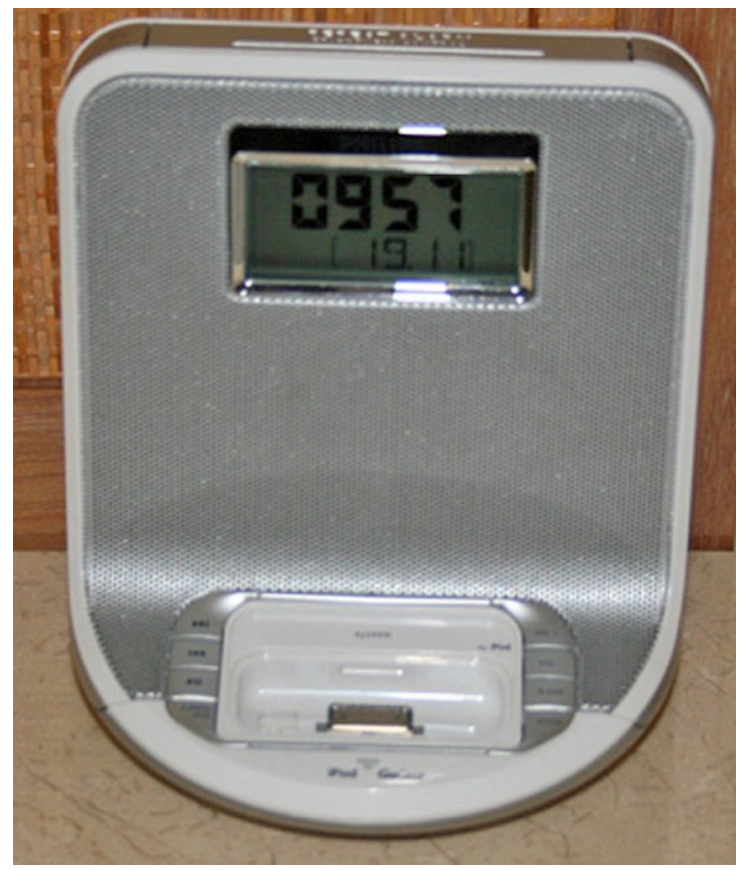

Fonte: foto tirada pelo autor, em visita realizada dia 19/11/2011 


\subsubsection{Resumo das Ações Sensoriais}

Quadro 4 - L'Hotel - Resumo das ações sensoriais

\begin{tabular}{|l|l|l|l|l|l|}
\hline \multicolumn{1}{|c|}{ Pontos de contato } & Visão & Olfato & Tato & Paladar & Audição \\
\hline Apartamentos & & & & & \\
\hline Áreas comuns & & & & & \\
\hline Bares e restaurantes & & & & & \\
\hline Centro de convenções & & & & & \\
\hline Áreas de lazer / esporte & & & & & \\
\hline Pessoas & & & & & \\
\hline Comunicação & & & & & \\
\hline
\end{tabular}

Fonte: elaborado pelo autor

Como visto no quadro acima, o L’Hotel desenvolve um razoável número de ações sensoriais em seus diversos pontos de contato. Da mesma maneira que observado nos outros hotéis já analisados, aqui também se percebe um misto de ações desenvolvidas a partir de um conceito claro e com objetivos definidos, e também ações que são realizadas porque este é o padrão.

No sentido da visão, existe bastante harmonia principalmente em relação à decoração, arquitetura e cromia de diversas áreas, seguindo um padrão muito claro que se adequa ao posicionamento de um hotel low-profile, que foca o intimismo. Talvez o ponto que destoe neste quesito seja o centro de convenções, que claramente não tem o mesmo requinte visual das outras áreas.

Por outro lado, a ligação entre o hotel e a cidade, que é outra das preocupações do L'Hotel, fica evidente na decoração, com o uso de obras que remetem à cidade. A busca por um maior intimismo também é refletido nas áreas comuns, como o lounge com piano bar, e toda a atmosfera criada com móveis e iluminação que estimulam o intimismo buscado. 
O sentido do olfato é um dos mais marcantes do L'Hotel, e tem uma intenção de provocar memória olfativa nos hóspedes. O aroma é único em todas as áreas. É um aroma exclusivo, e muito apreciado pelos hóspedes. O uso deste aroma como base também para os amenities ofertados pelo hotel mostra a intencionalidade que a ação tem.

As ações relacionadas ao tato são mais tímidas. O hotel segue a mesma linha que os outros, no sentido de se preocupar com a cama, o enxoval, a climatização. No entanto, percebe-se um toque a mais no L'Hotel em relação ao tato, e que também está ligado à visão, que é o uso de texturas diferentes e que fogem do convencional em locais como as portas e paredes.

O sentido do paladar é explorado de maneira mais efetiva principalmente no café da manhã que, como apontado, tem uma quantidade de itens bem superior aos outros. Nas outras ações em que o paladar também é aguçado, com a oferta do espumante no momento do check in, e nos pratos de doces que são colocados nos quartos, a ideia que passa é que estas não foram ações desenvolvidas especificamente com o objetivo de explorar a experiência sensorial do consumidor, mas sim oferecer uma gentileza a mais para os hóspedes.

Por fim, o sentido da audição parece ser explorado com base mais sólida em relação ao posicionamento do hotel. Nota-se isto em pelo menos duas ações diferentes: na escolha da música ambiente, com a preocupação de se fazer uma seleção mais adequada à São Paulo, e que é diferente das músicas do hotel no Rio de Janeiro, para reforçar a ideia de um hotel que faz parte da cidade, e também no script dos funcionários, chamando os hóspedes pelo nome. Isso claramente reforça a proposta de um hotel mais intimista. 


\subsection{Análises consolidadas dos casos.}

Após a descrição dos casos e a comparação de seus aspectos principais com o que foi apresentado no referencial teórico, será apresentado um resumo comparativo dos casos, conforme proposto por YIN (2006).

Para facilitar a análise, foram desenvolvidos 5 quadros - um para cada sentido. Em cada um destes quadros foram sintetizados 3 fatores:

a) Pontos de contato usados, ou seja, quais são os pontos de contato que foram estudados na pesquisa de campo e que tem algum apelo para o sentido analisado.

b) Ações efetivas de Marketing Experiencial, ou seja, das ações estudadas, quais aquelas que realmente podem ser classificadas como ações desenvolvidas efetivamente para se agregar valor através da exploração de um sentido.

c) Ações padronizadas, que são as ações feitas pelo hotel e que, no limite, estimula algum dos sentidos, mas que foi desenvolvida muito mais em função do padrão existente na categoria. 
Quadro 5 - Análise do uso do sentido da Visão

\begin{tabular}{|c|c|}
\hline Hyatt & $\begin{array}{l}\text { - Pontos de contato usados } \\
\checkmark \text { Apartamentos } \\
\checkmark \text { Áreas comuns } \\
\checkmark \text { Bares e Restaurantes } \\
\checkmark \text { Centro de Convenções } \\
\checkmark \text { Lazer e Esporte } \\
\checkmark \text { Pessoas } \\
\text { - Ações Efetivas de Marketing Experiencial } \\
\checkmark \quad \text { Quartos, lobby, centro de convenções grandiosos para passar conceito } \\
\text { - Ações padronizadas } \\
\checkmark \text { Uniforme funcionários }\end{array}$ \\
\hline Hilton & $\begin{array}{l}\text { Pontos de contato usados } \\
\checkmark \text { Apartamentos } \\
\checkmark \text { Áreas comuns } \\
\checkmark \text { Bares e Restaurantes } \\
\checkmark \text { Pessoas } \\
\checkmark \text { Comunicação } \\
\text { - Ações Efetivas de Marketing Experiencial } \\
\checkmark \text { Restaurante Canvas } \\
\checkmark \text { Obras de arte no lobby e áreas comuns } \\
\text { - Ações padronizadas } \\
\checkmark \text { Irrelevantes }\end{array}$ \\
\hline L'Hotel & $\begin{array}{l}\text { Pontos de contato usados } \\
\checkmark \text { Apartamentos } \\
\checkmark \text { Áreas comuns } \\
\checkmark \text { Bares e Restaurantes } \\
\checkmark \text { Lazer e esporte } \\
\checkmark \text { Pessoas } \\
\checkmark \text { Comunicação } \\
\text { - Ações Efetivas de Marketing Experiencial } \\
\checkmark \text { Arquitetura e decoração em harmonia com intimismo } \\
\text { - Ações padronizadas } \\
\checkmark \text { Irrelevantes }\end{array}$ \\
\hline
\end{tabular}


Quadro 6 - Análise do uso do sentido do Olfato

\begin{tabular}{|c|c|}
\hline Hyatt & $\begin{array}{l}\text { - Pontos de contato usados } \\
\checkmark \text { Apartamentos } \\
\checkmark \text { Áreas comuns } \\
\checkmark \text { Lazer e Esporte } \\
\checkmark \text { Pessoas } \\
\text { - Ações Efetivas de Marketing Experiencial } \\
\checkmark \quad \text { Aromatização de ambientes com aromas brasileiros } \\
\text { - Ações padronizadas } \\
\checkmark \text { Recomendações para funcionários }\end{array}$ \\
\hline Hilton & $\begin{array}{l}\text { - Pontos de contato usados } \\
\checkmark \text { Pessoas } \\
\text { - Ações Efetivas de Marketing Experiencial } \\
\checkmark \text { Inexistente } \\
\text { - Ações padronizadas } \\
\checkmark \text { Recomendações para funcionários }\end{array}$ \\
\hline L'Hotel & $\begin{array}{l}\text { - Pontos de contato usados } \\
\checkmark \text { Apartamentos } \\
\checkmark \text { Áreas comuns } \\
\checkmark \text { Centro de Convenções } \\
\checkmark \text { Lazer e Esporte } \\
\checkmark \text { Pessoas } \\
\checkmark \text { Comunicação } \\
\text { - Ações Efetivas de Marketing Experiencial } \\
\checkmark \quad \text { Aromatização de todo o hotel } \\
\text { - Ações padronizadas } \\
\checkmark \text { Irrelevantes }\end{array}$ \\
\hline
\end{tabular}




\section{Quadro 7 - Análise do uso do sentido do Tato}

\begin{tabular}{|c|c|}
\hline Hyatt & $\begin{array}{l}\text { - Pontos de contato usados } \\
\checkmark \quad \text { Apartamentos } \\
\checkmark \quad \text { Lazer e Esporte } \\
\text { - Ações Efetivas de Marketing Experiencial } \\
\checkmark \quad \text { Inexistente } \\
\text { - Ações padronizadas } \\
\checkmark \text { Enxoval, cama, ducha }\end{array}$ \\
\hline Hilton & $\begin{array}{l}\text { - Pontos de contato usados } \\
\checkmark \text { Apartamentos } \\
\checkmark \text { Áreas comuns } \\
\text { - Ações Efetivas de Marketing Experiencial } \\
\checkmark \text { Janela nos banheiros dos quartos } \\
\checkmark \text { Pisos diferentes para ambientes diferentes no quarto } \\
\text { - Ações padronizadas } \\
\checkmark \text { Cama e enxoval }\end{array}$ \\
\hline L'Hotel & $\begin{array}{l}\text { - Pontos de contato usados } \\
\checkmark \text { Apartamentos } \\
\checkmark \text { Áreas comuns } \\
\checkmark \text { Lazer e Esporte } \\
\text { - Ações Efetivas de Marketing Experiencial } \\
\checkmark \text { Inexistente } \\
\text { - Ações padronizadas } \\
\checkmark \text { Camas e enxoval } \\
\checkmark \text { Texturas nas portas e paredes }\end{array}$ \\
\hline
\end{tabular}




\section{Quadro 8 - Análise do uso do sentido do Paladar}

\begin{tabular}{|c|c|}
\hline Hyatt & $\begin{array}{l}\text { - Pontos de contato usados } \\
\checkmark \text { Apartamentos } \\
\checkmark \text { Bares e Restaurantes } \\
\checkmark \text { Comunicação } \\
\text { - Ações Efetivas de Marketing Experiencial } \\
\checkmark \text { Cardápios com toques de culinária brasileira } \\
\checkmark \text { Promoções como harmonização de vinhos e aulas de culinária } \\
\text { - Ações padronizadas } \\
\checkmark \text { Irrelevantes }\end{array}$ \\
\hline Hilton & $\begin{array}{l}\text { - Pontos de contato usados } \\
\checkmark \text { Apartamentos } \\
\checkmark \text { Bares e Restaurantes } \\
\checkmark \text { Comunicação } \\
\text { - Ações Efetivas de Marketing Experiencial } \\
\checkmark \text { Brindes de chocolates e pimentas } \\
\text { - Ações padronizadas } \\
\checkmark \text { Irrelevantes }\end{array}$ \\
\hline L'Hotel & $\begin{array}{ll}\text { - } & \text { Pontos de contato usados } \\
\checkmark & \text { Apartamentos } \\
\checkmark & \text { Áreas comuns } \\
\checkmark & \text { Bares e Restaurantes } \\
\checkmark & \text { Lazer e Esporte } \\
\text { - Ações Efetivas de Marketing Experiencial } \\
\checkmark \text { Café da manhã } \\
\text { - Ações padronizadas } \\
\checkmark \text { Prato de doces nos quartos } \\
\checkmark \text { Espumante no check in }\end{array}$ \\
\hline
\end{tabular}




\section{Quadro 9 - Análise do uso do sentido da Audição}

\begin{tabular}{|c|c|}
\hline Hyatt & $\begin{array}{l}\text { - Pontos de contato usados } \\
\checkmark \text { Áreas comuns } \\
\checkmark \text { Bares e Restaurantes } \\
\checkmark \text { Pessoas } \\
\checkmark \text { Comunicação } \\
\text { - Ações Efetivas de Marketing Experiencial } \\
\checkmark \text { Script dos funcionários - "É um prazer" } \\
\text { - Ações padronizadas } \\
\checkmark \text { Música ambiente }\end{array}$ \\
\hline Hilton & $\begin{array}{l}\text { - Pontos de contato usados } \\
\checkmark \quad \text { Pessoas } \\
\text { - Ações Efetivas de Marketing Experiencial } \\
\checkmark \text { Inexistente } \\
\text { - Ações padronizadas } \\
\checkmark \text { Script funcionários }\end{array}$ \\
\hline L'Hotel & $\begin{array}{l}\text { - Pontos de contato usados } \\
\checkmark \text { Apartamentos } \\
\checkmark \text { Áreas comuns } \\
\checkmark \text { Bares e Restaurantes } \\
\checkmark \text { Lazer e Esporte } \\
\checkmark \text { Pessoas } \\
\text { - Ações Efetivas de Marketing Experiencial } \\
\checkmark \text { Seleção de música ambiente } \\
\checkmark \text { Script dos funcionários chamando hóspedes pelo nome } \\
\text { - Ações padronizadas } \\
\checkmark \text { Irrelevantes }\end{array}$ \\
\hline
\end{tabular}

Pelo resumo dos casos expostos acima, é percebido que o uso das experiências sensoriais pelos hotéis da categoria 5 estrelas da cidade de São Paulo ainda está numa fase inicial. 
Num primeiro momento deve ser destacado que efetivamente algumas ações são desenvolvidas buscando realmente a exploração de um ou outro sentido humano como meio de agregar valor no serviço consumido.

Estas ações não fazem distinção entre o público corporativo dos hotéis e que, em princípio teria uma tendência maior a consumir o serviço de forma utilitária, e o público de lazer, que tem maior tendência de buscar o consumo hedônico.

Independente do tipo de consumo, é claramente perceptível que, de fato, algumas poucas ações são desenvolvidas de maneira planejada.

Quando os executivos entrevistados foram questionados a respeito do conceito que teriam sobre Marketing Experiencial, nenhum deles soube dar nenhum tipo de definição, embora, como visto, não exista consenso a respeito deste conceito.

Isso significa que as ações que são realmente desenvolvidas com o objetivo claro de explorar alguma experiência sensorial, não são feitas tendo o conceito - qualquer conceito - de Marketing Experiencial como base. E isso reforça uma ideia disseminada de que a prática de marketing ainda tem um componente empírico bastante alto.

Mas isso não invalida o fato de que algumas ações - sob o nome que for - que buscam oferecer ao consumidor uma experiência mais completa já são desenvolvidas pelos hotéis. E isso tem seu lado positivo, pois em nenhum momento da pesquisa foi percebido algum tipo de restrição ao conceito de Marketing Experiencial.

Por outro lado, também é verdade que muitas das ações desenvolvidas tem como razão fundamental o fato de ser um padrão nos hotéis da mesma categoria. Evidentemente, isso que Levitt chama de produto esperado não pode deixar de ser ofertado.

No entanto, percebe-se uma postura geral pouco crítica em relação a esta padronização. A exceção é o L'Hotel, que questiona um pouco mais algumas práticas desenvolvidas.

Indo além, pode-se também afirmar que algumas práticas são padronizadas na sua essência, e não necessariamente na sua forma. Por exemplo, a oferta de um enxoval de qualidade é 
esperado por qualquer consumidor de um hotel da categoria 5 estrelas. Portanto, oferecer um enxoval que tenha, apenas para ilustrar, um lençol egípcio de 600 fios, travesseiros com plumas de ganso, e toalhas felpudas no banheiro, faz parte do produto esperado.

No entanto, em princípio, não existe restrição para que se utilize o mesmo lençol ou a mesma toalha com padronagens e/ou texturas diferentes. A falta deste tipo de questionamento chamou um pouco nossa atenção.

Na comparação dos hotéis, fica a impressão de que o L'Hotel é aquele que mais desenvolve ações de Marketing Experiencial.

Em resumo, pode-se dizer que os hotéis estão em níveis razoavelmente semelhantes em relação à prática de ações de Marketing Experiencial, com uma pequena vantagem para o L'Hotel.

Porém, olhando cada um dos casos estudados, fica claro que ainda existe uma enorme quantidade de ações que podem ser desenvolvidas, tanto em relação aos pontos de contato, como também em relação aos sentidos.

Após o resumo comparativo dos casos, serão apresentadas as análises e considerações finais deste estudo. 


\section{CONSIDERAÇÕES FINAIS}

Parece que a questão experiencial ainda tem um longo caminho a percorrer para que se possa ter maior consistência no seu conceito. Isso porque ainda existe muita confusão em torno do conceito de experiência por causa de inúmeros termos que são usados como sinônimos e/ou exemplos de experiência, sem mencionar os diferentes contextos em que o termo é utilizado.

No entanto, independente das diferentes abordagens, parece existir um consenso a respeito da importância de se trabalhar melhor as experiências sensoriais do consumidor, para que ele possa tocar, sentir e experimentar o produto ou serviço.

Também parece ser consenso que essas experiências acabam por influenciar o comportamento e a percepção dos consumidores, além de proporcionar maior envolvimento emocional com a marca.

Cabe aqui, portanto, a opinião de BERRY et al (2002), que afirma que:

"Sempre que um cliente compra um produto ou serviço de uma empresa, terá uma experiência - boa, má ou indiferente. Por isso a questão que se coloca é o quão efetivamente a empresa gerencia a experiência. Organizações que simplesmente ajustarem o foco na experiência do cliente em situações isoladas de seus negócios, como por exemplo, oferecendo apenas um pequeno entretenimento, ficarão decepcionadas com os resultados. As melhores empresas serão as que combinarem os beneficios funcionais e emocionais em suas ofertas, criando laços afetivos com os clientes que os concorrentes terão dificuldades para cortar. Para competir com sucesso, um número crescente de organizações está aplicando princípios e ferramentas de gestão da experiência do cliente para gerar fidelização. E, ao contrário de muitos produtos ou serviços, a natureza holística destes projetos experiencias são muito mais dificeis para os concorrentes copiarem." 
Com os estudos feitos, pode-se concluir que os hotéis analisados têm algumas ações de marketing que efetivamente exploram os sentidos humanos para criar valor para os seus hóspedes. No entanto, essas ações ainda estão numa fase inicial, e existe ainda muito por fazer.

É importante lembrar o impacto econômico que o turismo tem, e seu constante crescimento na economia mundial. Num mundo cada vez mais globalizado, a disputa por mercado também no turismo deve se intensificar e, sendo os hotéis um dos principais atores deste cenário, os investimentos em marketing devem começar já.

Se isso já é importante numa situação cotidiana, com as perspectivas que aparecem no horizonte em função da realização da Copa do Mundo e das Olimpíadas aqui no Brasil, é ainda mais importante que a infraestrutura turística esteja pronta para ofertar produtos diferenciados para os hóspedes e, através de uma experiência positiva, tentar conquistar seu retorno.

Evidentemente que esta tese não tem a pretensão de esgotar o assunto. Ao contrário, o objetivo é que ela possa servir de estímulo para que outros estudos na área possam ser feitos. Como forma de contribuir para isso, foram deixadas algumas sugestões para futuros estudos:

a) Pesquisas que procurem desenvolver uma escala para se avaliar a experiência sensorial do cliente de maneira ampla, holística.

b) Analisar, de maneira mais específica, o comportamento de compra do cliente da hotelaria em seus diversos segmentos e, mais especificamente, pesquisar a influência que os sentidos exercem no comportamento de compra destes clientes.

c) Estudar se existe diferença, sob o ponto de vista das experiências sensoriais, no comportamento de compra do cliente de lazer e do cliente corporativo.

d) Pesquisar que outros setores do turismo podem desenvolver ações de marketing experiencial. 
e) Pesquisar como as ações de Marketing Experiencial poderão ser trabalhadas no ambiente virtual.

f) Aprofundar os estudos sobre marketing experiencial, buscando o desenvolvimento de um conceito menos difuso.

Ao terminar a tese, a sensação de dever cumprido acaba servindo de mola propulsora para os novos desafios que certamente virão. Desafios que, se Deus quiser, serão enfrentados não apenas pelo seu sentido utilitário, mas pela satisfação hedônica que as vitórias trazem. Desafios que sejam exatamente como foi o desenvolvimento desta tese - uma experiência única e memorável. 


\section{REFERÊNCIAS BIBLIOGRÁFICAS}

AAKER, David. A.; JOACHIMSTHALER, Erich. Como construir marcas líderes. São Paulo: Futura, 2000.

ARIELY, Dan. Previsivelmente irracional. Rio de Janeiro: Elsevier, 2008.

ASSOCIAÇÃO BRASILEIRA DA INDÚSTRIA HOTELEIRA (ABIH) - Disponível em $<$ http://www.abih.org.br> - primeiro acesso em 15/7/2011.

BABIN, Barry J. et al. Work and/or Fun: Measuring Hedonic and Utilitarian Shopping Value. Journal of Consumer Research, vol. 20, Mar/1994.

BALANZÁ, Isabel Milio; NADAL, Mónica Cabo. Marketing e comercialização de produtos turísticos. São Paulo: Pioneira Thomson Learning, 2003.

BARTELS, Robert. The history of marketing thought. Irwin, 1976.

BATRA, Rajeev; AHTOLA, Olli T. Measuring the Hedonic and Utilitarian Sources of Consumer Attitudes. Marketing Letters 2:2, p. 159-170, 1990.

BEDBURY, Scott. O novo mundo das marcas. Rio de Janeiro: Campus, 2002.

BELCH, George E.; BELCH, Michael A. Propaganda e promoção. São Paulo: McGraw Hill, 2008.

BENI, Mário Carlos. Análise estrutural do turismo. São Paulo: Ed. Senac, 1998.

BERRY, Leonard L. et al. Managing the total customer experience. MIT Sloan Management Review, Spring/2002.

BETTMAN, James R. An information processing theory of consumer choice. Reading. MA: Addison-Wesley, 1979 - citado in HOLBROOK \& HIRSCHMAN, set 1982. 
BITNER, Mary Jo. Servicescapes: the impact of physical surroundings on customer and employees. Journal of Marketing, vol. 56, April/1992.

BONE, Paula; FRANCE, Karen. Package Graphics and Consumer Product Beliefs. Journal of Business and Psychology, vol. 15, nº 3, Spring/2001.

BOSMANS, Anick. Scents and Sensibility: When Do (In)Congruent Ambient Scents Influence Product Evaluations? Journal of Marketing, vol. 70, p. 32-43, Jul/2006.

BOSMANS, Anick; BAUMGARTNER, Hans. When Feelings Influence Product Evaluations (and When They Do Not): Discrete-Affect - Validation and the Role of Consumption Motives. Advances in Consumer Research, vol. 32, 2005.

BRENGMAN, Malaika; GEUENS, Maggie. The Four Dimensional Impact of Color on Shopper's Emotions. Advances in Consumer Research, vol. 31, p. 122-128, 2004.

CAESARS PALACE 2011. Disponível em: < http://www.caesarspalace.com > Primeiro acesso em 03/08/2011.

CAMPOMAR, Marcos C.. Do uso de "estudo de caso" em pesquisas para dissertações e teses em administração. Revista de Administração. São Paulo, n.3, v.26, p. 95-97, Julho/Setembro, 1991.

CAMPOMAR, Marcos C.; IKEDA, Ana A. O planejamento de marketing e a confeç̧ão de planos: dos conceitos a um novo modelo. São Paulo: Saraiva, 2006.

CARBONE, Lewis. P.; HAECKEL, Stephan. H. Engineering customer experiences. Marketing Management, nº 3, p. 9-19, Winter/1994.

CARLZON, Jan. A hora da verdade. Rio de Janeiro: Sextante, 2005.

CARU, Antonella et al. Pleasure and Enjoyment in the Consumption Experience: The Case of ICT-Based Services. European Advances in Consumer Research, vol. 8, 2008. 
CARU, Antonella; COVA, Bernard. How to facilitate immersion in a consumption experience: Appropriation operations and service elements. Journal of Consumer Behaviour, p. 4-14, February/2006.

CASTELLI, Geraldo. Marketing hoteleiro. Caxias do Sul: Educs, 1991.

CASTRO, Guilherme. Guilherme Castro. Entrevista (18/11/2011). Entrevistador: Marcelo Chiavone Pontes. São Paulo: Hilton, 2011. Arquivo sonoro em formato eletrônico. Entrevista realizada no hotel Hilton.

CHAN, Elaine; MUKHOPADHYAY, Anirban. When Choosing Makes a Good Thing Better: Temporal Variations in the Valuation of Hedonic Consumption. Journal of Marketing Research, vol. XLVII, p. 497-507, Jun/2010

CIRCUS CIRCUS. 2011. Disponível em: <http://www.circuscircus.com > Primeiro acesso em 03/08/2011.

CLEMENT, Michel et al. Diffusion of Hedonic Goods: A Literature Review. The International Journal on Media Management, vol. 8, nº 4, p.155-163, 2006.

COBRA, Marcos; BREZZO, Roberto. O novo marketing. Rio de Janeiro: Elsevier, 2010.

CONNELLAN, Tom. Nos bastidores da Disney. São Paulo: Futura, 1998.

COSTA, Jurandir Freire. O vestígio e a aura: corpo e consumismo na moral do espetáculo. Rio de Janeiro: Garamond, 2004.

Documento Referencial Turismo no Brasil 2011/2014. Disponível em $<$ http://www.turismo.gov.br> - primeiro acesso em 17/07/2011.

DONOVAN, Robert J. et al. Store atmosphere and purchasing behavior. Journal of Retailing, vol. 70, nº 3, p. 283-294, 1994. 
DUBÉ, Lauret et al. The effects of background music on consumers' desire to affiliate in buyer-seller interactions. Psychology \& Marketing, vol. 12, 1995.

EISENHARDT, Kathleen M. Building theories from case study research. The Academy of Management Review. Briarcliff Minor, v.14, n.4, p.532-551, Oct. 1989.

ENGEL, James F. et al. Comportamento do consumidor. Rio de Janeiro: Ed. Livros Técnicos e Científicos, 2000.

EXCALIBUR. 2011. Disponível em: <http://www.excalibur.com > primeiro acesso em 03/08/2011.

FABER, Karina. Karina Faber. Entrevista (29/11/2011). Entrevistador: Marcelo Chiavone Pontes. São Paulo: Grand Hyatt, 2011. Arquivo sonoro em formato eletrônico. Entrevista realizada no hotel Grand Hyatt.

FEATHERSTONE, Mike. Cultura de consumo e pós-modernismo. São Paulo: Studio Nobel, 1995.

FIORE, Ann Marie et al. Effects of a Product Display and Environmental Fragrancing on Approach Responses and Pleasurable Experiences. Psychology \& Marketing, vol. 17, pp. 27-54, January/2000

FLAMINGO. 2011. Disponível em: <http://www.flamingolasvegas.com > primeiro acesso em 03/08/2011.

GENTILE, Chiara et al. How to sustain the customer experience: an overview of experience components that co-create value with the customer. European Management Journal, vol. 25, issue 5, p. 395-410, October/2007.

GODOY, Arilda S. Pesquisa qualitativa: tipos fundamentais. Revista RAE, São Paulo, v.35, n.3, p. 20- 29, Mai/Jun 1995.

GORZ, André. O imaterial: conhecimento, valor e capital. São Paulo: Annablume, 2005. 
GREWAL, Dhruv et al. Customer experience management in retail: an organizing framework. Journal of Retailing. vol. 85, $\mathrm{n}^{\circ}$ 1, 2009.

GREWAL, Dhruv et al. The effects of wait expectations and store atmosphere evaluations on patronage intentions in service-intensive retail stores. Journal of Retailing, vol. $79, \mathrm{n}^{\circ} 4$, pp. 259-268, 2003.

GRÖNROSS, Christian. Marketing: gerenciamento e serviços. $3^{\text {a }}$ edição - Rio de Janeiro: Elsevier, 2009.

GULAS, Charles S.; BLOCK, Peter H. Right under our noses: ambient scent and customer response. Journal of Business and Psychology, vol. 10, Fall/1995.

HEMMINGTON, Nigel. From Service to Experience: Understanding and Defining the Hospitality Business. The Service Industries Journal, vol.27, $\mathrm{n}^{\mathrm{o}} 6$, pp. 747-755, September/2007.

HERrington, J. Duncan; CAPELlA, Louis M. Practical Applications of Music in Service Settings. Journal of Services Marketing, vol. 8, nº 3, pp. 50-65, 1994.

HILTON. 2011. Disponível em: < http://www.hiltonworldwide.com > primeiro acesso em 04/10/2011.

HOLBROOK, Morris B.; HIRSCHMAN, Elizabeth C. Hedonic consumption: emerging concepts, methods and propositions. Journal of Marketing, Summer, 1982a

HOLBROOK, Morris B.; HIRSCHMAN, Elizabeth C. The experiential aspects of consumption: consumers fantasies, feelings and fun. The Journal of Consumer Research, vol. 9, Set/1982b.

HYATT São Paulo. 2011. Disponível em: < http://saopaulo.grand.hyatt.com.br > primeiro acesso em 06/10/2011.

HYATT. 2011. Disponível em: < http://www.hyatt.com > primeiro acesso em 05/10/2011. 
IKEDA, Ana A. et al. Marketing vivencial: o caso de eventos musicais no shopping. Revista de Administração Mackenzie, ano 6, nº 3, p. 72-87, 2005.

IMPERIAL PALACE. 2011. Disponível em: <http://www.imperialpalace.com > primeiro acesso em 03/08/2011.

ISMAIL, Ahmed R. et al. Customer experiences with brands: literature review and research directions. The Marketing Review, vol. 11, nº 3, p. 205-225, 2011.

KALTCHEVA, Velitchca; WEITZ, Barton. When should a retailer create an exciting store environment? Journal of Marketing, vol. 70, January/2006.

KELLARIS, James J. et al. Music and Time Perception: When Does a Song Make It Seem Long? American Marketing Association, Winter 2007.

KERIN, Roger A. et al. Marketing. São Paulo: Ed. Mc-Graw Hill, 2007.

KOTLER, Philip et al. Marketing de lugares: como conquistar crescimento de longo prazo na América Latina e Caribe. São Paulo: Prentice Hall, 2006.

KOTLER, Philip. Administração de marketing: a edição do milênio. $10^{a}$ edição - São Paulo: Prentice Hall, 2000.

KOTLER, Philip. Atmospherics as a marketing tool. Journal of Retailing, vol. 49, nº 4, p. 4864, Winter/1973-1974.

KOTLER, Philip; KELLER, Kevin L. Administração de marketing. São Paulo: Ed. Pearson, 2006.

KOTLER, Philip; LEVY, Sidney. Broadening the concept of marketing. Journal of Marketing, vol. 31 - Jan/1969.

KRISHNA, Aradhna. Interaction of Senses: The Effect of Vision Versus Touch on the Elongation Bias. Journal of Consumer Research, vol. 32, p. 557-566, Mar/2006. 
KUAZAQUI, Edmir. Marketing turístico e de hospitalidade. São Paulo: Makron Books, 2000 .

LAGE, Beatriz H. G.; MILONE, Paulo C. Economia do turismo. São Paulo: Ed. Papirus, 1991.

LEONARD, Hillary A. Consumption Fantasies: A Phenomenological View. Advances in Consumer Research, Volume 32, 2005.

LEVITT, Theodore. A imaginação de marketing. São Paulo: Atlas, 1985.

LEVITT, Theodore. Miopia em marketing. Harvard Business Review, vol. 38 - Jul/Aug 1960 .

LINDSTROM, Martin. A lógica do consumo. Rio de Janeiro: Nova Fronteira, 2009.

LINDSTROM, Martin. Brand sense. Porto Alegre: Bookman, 2007.

LIPOVETSKY, Gilles. A felicidade paradoxal: ensaio sobre a sociedade do hiperconsumo. São Paulo, Companhia das Letras, 2007.

LUXOR. 2011. Disponível em: < http://www.luxor.com > primeiro acesso em 03/08/2011.

MALHOTRA, Naresh K. Pesquisa de marketing: uma orientação aplicada. $3^{\text {a }}$ ed. Porto Alegre. Bookman, 2001.

MANDALY BAY. 2011. Disponível em: <http://www.mandalaybay.com > primeiro acesso em 03/08/2011.

MEYER, Christopher e SCHWAGER, André. Understanding customer experience. Harvard Business Review, p. 117-126, February/2007.

MGM. 2011. Disponível em: < http://www.mgmgrand.com > primeiro acesso em 03/08/2011. 
MILLIMAN, R. E. Using background music to affect the behavior of supermarket shoppers. Journal of Marketing, vol. 46, pp. 86 -91, 1982.

MILOTIC, Daniel. The impact of fragrance on consumer choice. Journal of Consumer Behaviour, vol.3, no 2, p.179-191, December/2003.

MINISTÉRIO DO TURISMO, 2011 - disponível em < http://www.turismo.gov.br> primeiro acesso em 17/07/2011.

MITCHELL, Deborah J. For the smell of it all: functions and effects of olfaction in consumer behavior. Advances in Consumer Research, vol.21, 1994.

MONTE CARLO. 2011. Disponível em: <http://www.montecarlo.com > primeiro acesso em 03/08/2011.

MOSSBERG, Lena. A Marketing Approach to the Tourist Experience. Scandinavian Journal of Hospitality and Tourism, vol. 7, nº 1, p. 59-74, 2007.

MOTA, Keila C. N. Marketing turístico: promovendo uma atividade sazonal. São Paulo: Atlas, 2001.

NELSON, Leif D.; MEYVIS, Tom. Interrupted Consumption: Disrupting Adaptation to Hedonic Experiences. Journal of Marketing Research, Vol. XLV, p. 654-664, Dec/2008.

O’GUINN, Thomas C. et al. Propaganda e promoção integrada da marca. São Paulo: Cengage Learning, 2008.

OKADA, Erica M. Justification Effects on Consumer Choice of Hedonic and Utilitarian Goods. Journal of Marketing Research, vol. 42, issue 1, Feb/2005.

PARASURAMAN, A. et al. The influence of multiple store environment cues on perceived merchandise value and patronage intentions. Journal of Marketing, vol.66, p.120-141, Apr/2002. 
PINE II, B. Joseph; GILMORE, James H. O Espetáculo dos negócios. Rio de Janeiro: Ed. Campus, 1999.

PINE II, B. Joseph; GILMORE, James H. Welcome to the experience economy. Harvard Business Review, Jul-Aug, 1998.

PLANET HOLLYWOOD. 2011. Disponível em: <http://www.planethollywoodresort.com > primeiro acesso em 03/08/2011.

Plano de Turismo Municipal Cidade de São Paulo 2011-2014. 2011. Disponível em $<$ http://www.cidadedesaopaulo.com/sp/br/sao-paulo-em-numeros $>$. Primeiro acesso em 20/07/2011.

POPCORN, Faith; MARIGOLD, Lyz. Click. Rio de Janeiro: Campus, 1997.

PORTER, Michael E. Estratégia competitiva: técnicas para análise de indústrias e da concorrência. Rio de Janeiro: Campus, 1986.

PORTER, Michael E. Vantagem Competitiva: Criando e Sustentando um Desempenho Superior. Rio de Janeiro: Campus, 1991.

PORTO BAY. 2011. Disponível em < http://www.portobay.com > primeiro acesso em $06 / 10 / 2011$.

RUSCHMANN, Doris. Marketing turístico: um enfoque promocional. Campinas: Ed. Papirus, 1991.

SANTOS, Claudio. Claudio Santos. Entrevista (08/11/2011). Entrevistador: Marcelo Chiavone Pontes. São Paulo: L’Hotel Porto Bay, 2011. Arquivo sonoro em formato eletrônico. Entrevista realizada no L'Hotel Porto Bay.

SÃO PAULO TURISMO - Disponível em <http://www.cidadedesaopaulo.com/sp/br/saopaulo-em-numeros $>$ - primeiro acesso em 20/07/2011. 
SCHMITT, Bernd H. Experiential marketing. Journal of Marketing Management, Jan/Apr 1999.

SCHMITT, Bernd H. Gestão da experiência do cliente. Porto Alegre: Bookman, 2004.

SCHMITT, Bernd H. Marketing experimental. São Paulo: Nobel, 2000.

SCHMITT, Bernd H.; SIMONSON, Alex. A estética do marketing. São Paulo: Nobel, 1997.

SCHRAMM, Carolina. Carolina Schramm. Entrevista (29/11/2011). Entrevistador: Marcelo Chiavone Pontes. São Paulo: Grand Hyatt, 2011. Arquivo sonoro em formato eletrônico. Entrevista realizada no hotel Grand Hyatt.

SCHWERINER, Mario E. R. Comportamento do consumidor: identificando necejos e supérfluos essenciais. São Paulo: Saraiva, 2006.

SELLTIZ, Claire. Métodos de pesquisa nas relações sociais. São Paulo: Herder, 1974.

SEMENIK, Richard; BAMOSSY, Gary. Princípios de marketing: uma perspectiva global. São Paulo: Makron Books, 1995.

SHAW, Colin. The DNA of customer experience: how emotions drive value. New York: Palgrave Macmilan, 2007.

SHAW, Colin; IVENS, John. Building great customer experiences. New York: Palgrave Mcmillan, 2002.

SHETH, Jagdish N. et al. Comportamento do cliente: indo além do comportamento do consumidor. São Paulo: Atlas, 2001.

SHIMP, Terence. Comunicação integrada de marketing: propaganda e promoção. $7^{\circ}$ ed. - Porto Alegre: Bookman, 2009. 
SOLOMON, Michael R. O comportamento do consumidor: comprando, possuindo e sendo. $5^{\text {a }}$ edição - Porto Alegre: Bookman, 2002.

SPANGENBERG, Eric R. et al. Measuring the Hedonic and Utilitarian Dimensions of Attitude: A Generally Applicable Scale. Advances in Consumer Research, vol. 24, 1997.

SPERDIN, Alexandra B.; PETERS, Mike. What Influences Guests' Emotions? The Case of High-quality Hotels. International Journal of Tourism Research, vol. 11, pp. 171-183, 2009.

THE MIRAGE. 2011. Disponível em: <http://www.mirage.com > primeiro acesso em 03/08/2011.

THE PALAZZO. 2011. Disponível em: < http://www.palazzo.com > primeiro acesso em 03/08/2011.

TOFFLER, Alvin. A empresa flexível. Rio de Janeiro: Ed. Record, 1985.

TOFFLER, Alvin. O Choque do Futuro. Rio de Janeiro: Ed. Record, 1970.

TOLEDO, Geraldo Luciano. Marketing e relações públicas: um conceito tridimensional. Anais do XVIII ENANPAD - Curitiba, 1994.

TREASURE ISLAND. 2011. Disponível em: <http://www.treasureisland.com > primeiro acesso em 03/08/2011.

TRIP ADVISOR. 2011. Disponível em: < www.tripadvisor.com > primeiro acesso em $09 / 10 / 2011$.

TURLEY, L. W.; CHEBAT, Jean-Charles. Linking retail strategy, atmospheric design and shopping behavior. Journal of Marketing Management, vol. 18, pp. 125-144, 2002.

UNWTO Tourism Highlights, edition 2011. Disponível em: http://www.eunwto.org/content/u27062 primeiro acesso em 19/07/2011. 
VOSS, Kevin E. et al. Measuring the Hedonic and Utilitarian Dimensions of Consumer Attitude. Journal of Marketing Research, vol. XL, Aug/2003, p. 310-320.

WALLS, Andrew et al. Understanding the Consumer Experience: an Exploratory Study of Luxury Hotels. Journal of Hospitality Marketing \& Management, vol. 20, issue 2, pp. 166197, 2011.

WORLD TOURISM ORGANIZATION, 2011. Disponível em: $<$ http://unwto.org/en/about/unwto> primeiro acesso em 18/07/2011.

YIN, Robert K. Estudo de caso: planejamento e métodos. $4^{\mathrm{a}}$ ed. Porto Alegre: Bookman, 2010.

ZEITHAML, Valarie A. Consumer Perceptions of Price, Quality, and Value: A Means-End Model and Synthesis of Evidence. Journal of Marketing, vol. 52, July/1988.

ZEITHAML, Valarie A.; BITNER, Mary J. Marketing de serviços: a empresa com foco no cliente. Porto Alegre: Bookman, 2003 


\section{APÊNDICE A}

\section{PROTOCOLO DE PESQUISA}

\section{VISÃO GERAL DO PROJETO DO ESTUDO DE CASO}

\subsection{Título}

Marketing experiencial ou o uso da experiência no marketing? Estudo de caso em hotéis 5 estrelas da cidade de São Paulo

\subsection{Objetivo do estudo}

Identificar o uso das experiências sensoriais nas ações de marketing desenvolvidas em hotéis 5 estrelas da cidade de São Paulo.

\section{PROCEDIMENTOS DE CAMPO}

\subsection{Aspectos Metodológicos}

Pesquisa de natureza exploratória, de caráter qualitativo, com o uso do método de estudo de casos múltiplos.

\subsection{Unidades de Análise}

- Hotel Grand Hyatt

- Hotel Hilton

- L’Hotel Porto Bay

\subsection{Fontes de evidência}

- Documentação

- Registros de arquivos

- Entrevistas

- Observações diretas 


\subsection{Instrumentos de Coleta de Dados}

- Entrevistas dirigidas

- Observação direta

- Análises de documentos

\subsection{Executores da Pesquisa}

- Pesquisador: Marcelo Chiavone Pontes

- Orientador: Prof. Dr. Marcos C. Campomar

\section{QUESTÕES DE ESTUDO DE CASO}

\subsection{Dados dos entrevistados:}

- Nome

- Cargo / Área

- Formação acadêmica / Experiência no mercado

- Atribuições

\subsection{Questões gerais sobre o hotel}

- Razão Social / Marca / Rede que integra

- Tamanho / Localização

- Tarifas

- Taxa de ocupação

- Infraestrutura existente / Serviços oferecidos

\subsection{Questões gerais sobre marketing}

- Perfil dos hóspedes e clientes

- Quais características diferenciam o hotel como 5 estrelas?

- Quais ações de marketing são desenvolvidas? Como são planejadas?

- Como é avaliada a satisfação dos clientes? Quais os resultados alcançados?

- Ações de Comunicação realizadas 


\subsection{Questões gerais sobre Marketing Experiencial}

- O que Marketing Experiencial significa para você?

- Seu hotel desenvolve ações de Marketing Experiencial? Quais?

- Se sim, descreva alguma ação de Marketing Experiencial que foi feita pelo seu hotel. Qual o resultado obtido?

\subsection{Questões específicas sobre o uso dos sentidos:}

- Visão:

○ Projeto arquitetônico

○ Decoração - áreas comuns e áreas privativas

○ Material de Comunicação

○ Funcionários: Uniformes, apresentação pessoal

- Produtos de uso dos hóspedes (restaurantes, academias, convenções, etc...)

○ Programação Visual, marcas, etc.

- Olfato:

○ Existe algum perfume exclusivo? Qual?

○ É específico para todo o hotel ou dividido por ambiente?

- Sistema de tratamento de odores?

○ Recomendação para funcionários?

- Tato:

○ Critério para escolha de enxoval, mobiliário, etc...

○ Uso de materiais específicos (ou restrição ao uso de algum?)

○ Sistema de refrigeração: temperatura padrão?

- Paladar:

○ Cardápio exclusivo?

- Restrições / obrigatoriedades

- Brindes para hóspedes

- Frigobar

○ Produtos de uso dos hóspedes (restaurantes, academias, convenções, etc...) 
- Audição:

○ Música ambiente? Critério?

○ Funcionários tem script?

○ Material de comunicação?

\subsection{Guia para o relatório do estudo de caso}

A análise dos casos será feita de maneira cruzada, onde vamos procurar sintetizar os dados de cada caso numa tabela, que será feita a partir de uma estrutura uniforme dos conceitos abordados no referencial teórico. Isso viabiliza uma comparação entre as semelhanças e diferenças dos casos estudados, enriquecendo a análise.

\begin{tabular}{|l|l|l|l|l|l|}
\hline Pontos de contato & Visão & Olfato & Tato & Paladar & Audição \\
\hline Apartamentos & & & & & \\
\hline Áreas comuns & & & & & \\
\hline Bares e restaurantes & & & & & \\
\hline Centro de convenções & & & & & \\
\hline Áreas de lazer / esporte & & & & & \\
\hline Pessoas & & & & & \\
\hline Comunicação & & & & & \\
\hline
\end{tabular}

As análises levarão em conta:

a) Tipo e quantidade de ações desenvolvidas

b) Grau de integração entre as ações

c) Planejamento das ações dentro de diretrizes previamente estabelecidas 